LATVIA

Human Development

Report

2019/2020

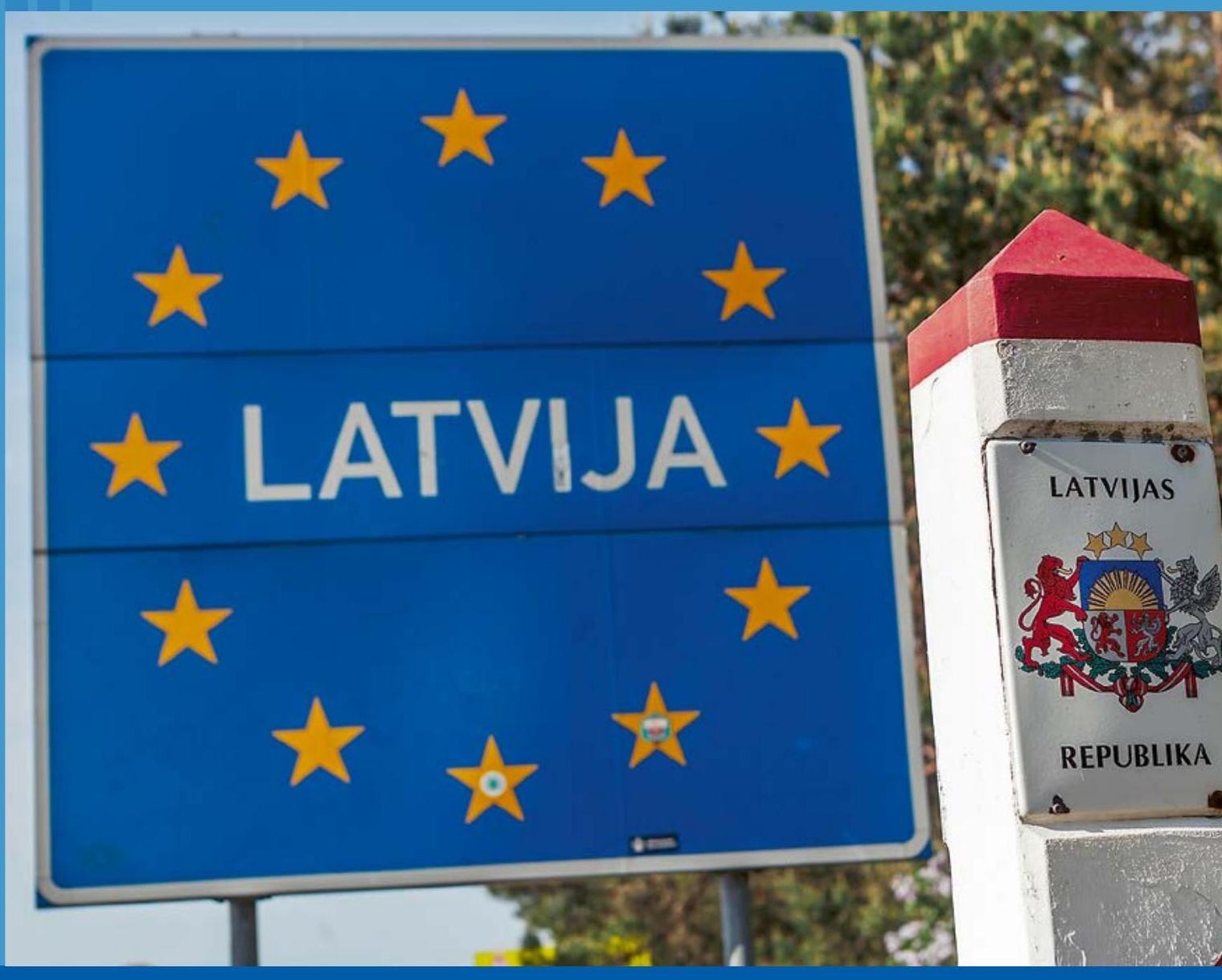

\title{
EUROPEANIZATION OF LATVIA
}




\section{LATVIA \\ Human Development Report}

\section{EUROPEANIZATION \\ OF LATVIA}

UNIVERSITY OF LATVIA

FACULTY OF

SOCIAL SCIENCES

Advanced Social and

Political Research Institute 
Latvia. Human Development Report 2019/2020. Europeanization of Latvia. Editor-in-chief Daunis Auers. Riga: Advanced Social and Political Research Institute of the University of Latvia, 2020, 152 pp., illustrations, tables, map. ISBN 978-9934$18-661-5$

The text of this publication is not copyright protected. This text, both in full and in part, may be used without prior permission; however, acknowledgement of the source is mandatory.
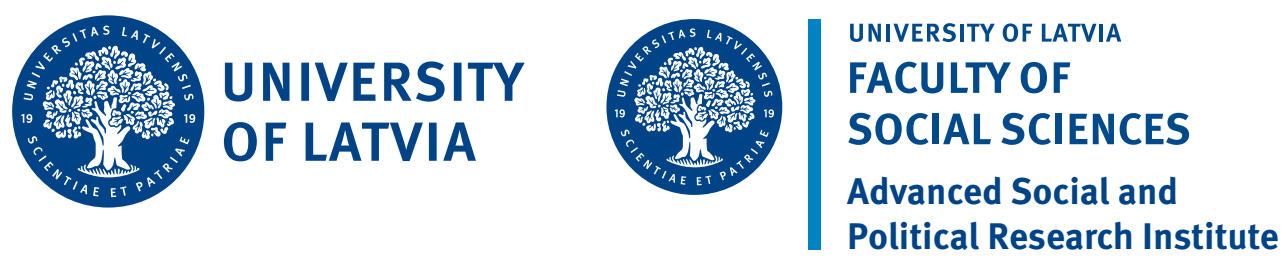

\author{
Editor-in-chief Daunis Auers \\ Project manager Anete Skrastiṇa \\ Statistician Anita Švarckopfa
}

Authors of Introduction: Daunis Auers, Ivo Rollis

Authors of Chapter 1: Daunis Auers, Iveta Reinholde, Toms Rostoks, Morten Hansen, Jānis Pleps

Authors of Chapter 2: Baiba Bela, Aija Zobena, Klinta Ločmele, Vita Zelče

The survey about the attitudes, values of Latvia's inhabitants and the awareness of Latvia's Europeanization was

conducted by the research centre SKDS.

Data tables about basic facts of Latvia, human development index and statistical indicators were prepared by

Anita Švarckopfa.

\title{
Scientific reviewers:
}

Dr. Žaneta Ozoliņa, Professor, University of Latvia, Faculty of Social Sciences, senior researcher at Advanced Social and Political Research Institute

Dr. Kārlis Bukovskis, Assistant Professor, Riga Stradins University, Department of Political Science, Deputy-director and researcher at Latvian Institute of International Affairs

Recommended for publication by the University of Latvia Board of Social Sciences, decision No. 2 of December 3, 2020.

\author{
Latvian language editor Ruta Puriña \\ English language editors Christopher Goddard, Daunis Auers \\ Translation from English into Latvian by Andra Damberga \\ Translation from Latvian into English by Ingūna Beķere \\ Cover design, inside page design and layout by Baiba Lazdina \\ Picture copyright shutterstock.com
}

The editors thank Aija Zobena and Renārs Felcis for their work on the survey and questionnaire.

The editors thank Jānis Ikstens, Aija Zobena, and Ilze Kāposta for organisational assistance. 


\section{Foreword}

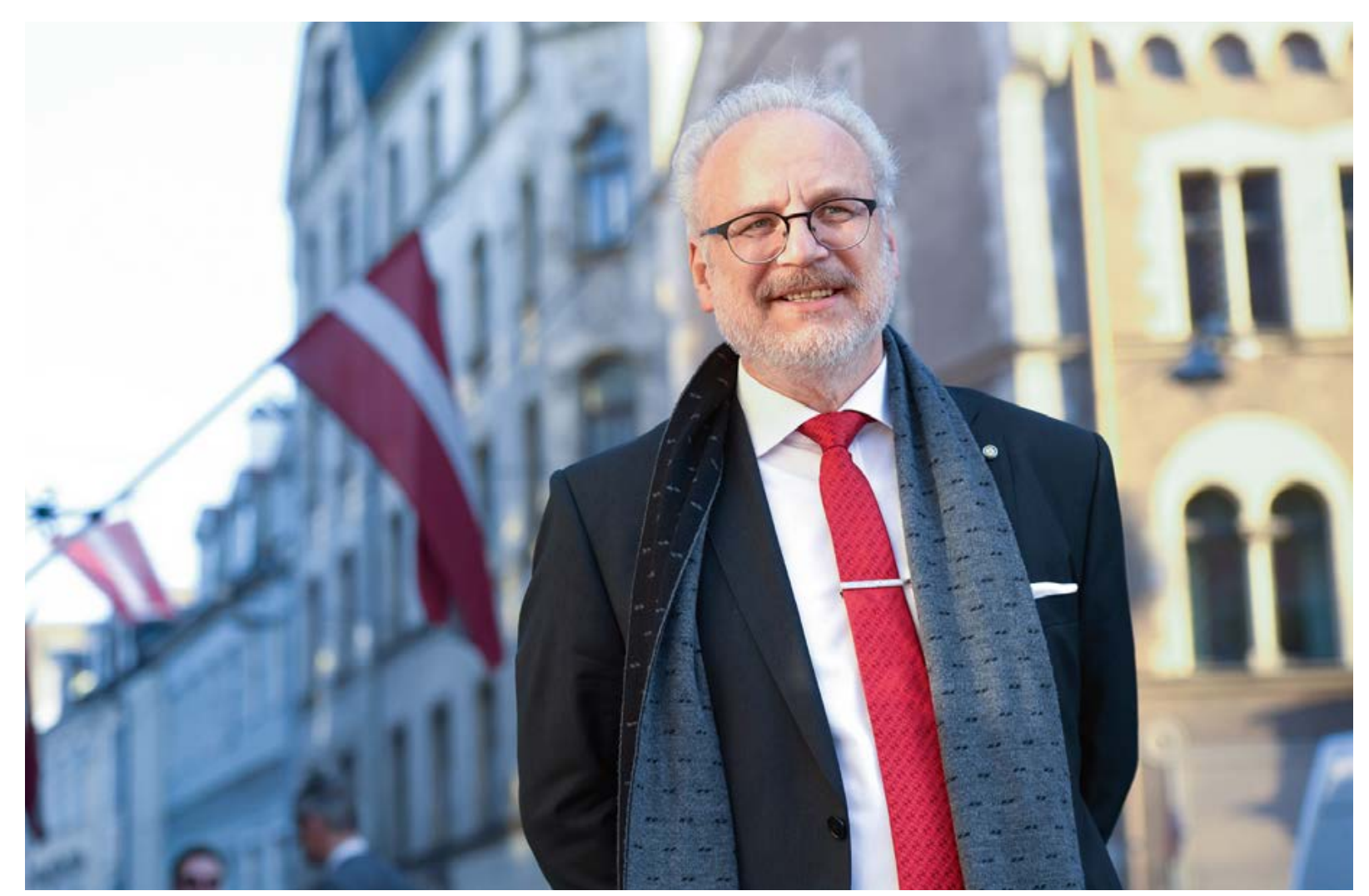

Throughout centuries the Latvian nation has evolved, existed and developed as a nation deeply rooted in European culture. We all have a twofold identity: we are Latvians and at the same time Europeans. We identify ourselves and care about not only our own local community, specific cultural and historical Latvian land or state of Latvia, but also Europe as a whole.

European identity, physical and spiritual affiliation with European culture has always been the cornerstone of Latvia's international stance, a crucial element of our political and legal culture and the way we think about our state. Human dignity, human rights and freedoms, democracy, rule of law and solidarity are European values that have naturally shaped and moulded Latvia as a nation state.

Article 68 of our constitution, Satversme, indicates the very reason we are a member of the European Union - Latvia needs Europe to strengthen its democracy. European dimension has enabled Latvia to establish a balanced and well-developed democracy and spread the rule of law across Latvia. It contributes to sustainable development of Latvia and serves our collective interests.

Whereas the preamble of our constitution, Satversme, provides a legal and political framework for European dimension of our policies that the state and the society should follow. It underscores the geopolitical affiliation of the state and nation of Latvia with European cultural space and makes us co-responsible for sustainable and democratic development of united Europe.

We can distinguish between three periods of Latvia's European integration. The first period began with restoration of independence in 1990/1991 and ended when we joined the European Union in 2004. Latvia needed these roughly 15 years to restructure its economy, political and legal system, realign its values with Western, specifically the European, democratic standards. It was the transition period for the state and the society, which transformed nearly every area of our life and taught us the importance of adjusting to new circumstances as quickly as possible. The experience now deeply embedded in the national consciousness, this tough experience, is a great advantage in modern, fast changing and unpredictable world, which allows us to adjust and even proactively prepare for any global shifts a lot easier than many other nations can, including the big ones.

The second period of European integration came after we became an EU member state. We had to transpose European Union laws, standards and political logic. This period, which began after 2004 and lasts until today, can be described as period of our European maturation. I truly believe that as we enter the third decade of the $21^{\text {st }}$ century thirty years after regaining our national independence and 15 years since joining the European Union, when a whole generation of Latvians has grown in 
fully independent Latvia, we are ready to enter the next phase of our European integration. The first two phases of European integration where asymmetric: Latvia had to take over European experiences, standards, thinking paradigms and values, whereas now we, the Latvians, conceive ourselves as true Europeans, just like Finns, Dutch, Austrians and other European nations.

That means we are no longer on the receiving end only - we are not merely transposing and implementing European standards, thinking paradigms or values. Our actions, way of thinking and values are European by default. That is our contribution to European project, the way we strengthen common European standards, help fulfil its values and development objectives. We play the same role as Finns, Germans, Estonians, Portuguese and other European nations in this process. And we are very much open to best practices of other European nations, as much as they are open to best practices coming from Latvia.

Undoubtedly, old Europe is still suffering from lack of ability to recognise the merits of our position, values and standards that are often considered 'less European' than theirs, which can partly be also blamed on our inability to break out of this 'asymmetrical infatuation'. However, in both cases this distinction between core and periphery seems to be outdated and out of place. We need to make conscious effort on both sides to end this prejudice as soon as possible.

We need to replace them with new collective paradigms based on experience, standards and values of all European nations, which are given equal recognition. United Europe is comprised of nations that are equal and treat each other as peers. All European Union member states, including Latvia, are equally responsible for the future of Europe. Europe needs Latvia and its contribution to the future development of common European project.

\section{Egils Levits}

President of the Republic of Latvia 


\section{Contents}

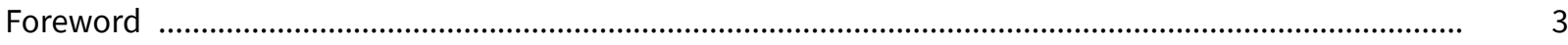

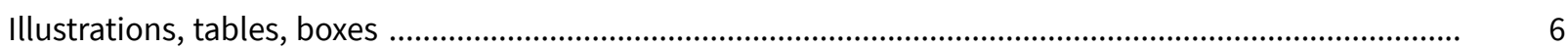

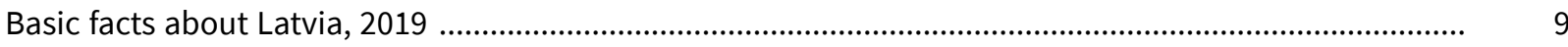

\section{Introduction}

Daunis Auers, Ivo Rollis ........................................................................................... 10

Part 1

Politics, law and the economy .............................................................................. 16

1.1. Daunis Auers. Europeanization of Latvia's political system ................................................... 17

1.2. Iveta Reinholde. Europeanization, soft instruments, and their consequences ...................... 26

1.3. Toms Rostoks. Europeanization of Latvia's foreign policy ......................................................

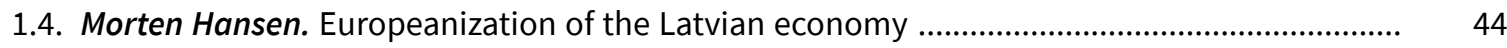

1.5. Jānis Pleps. The Satversme, the Constitutional Court and the European Union .................... 56

\section{Part 2}

Society, media and values ............................................................................... 66

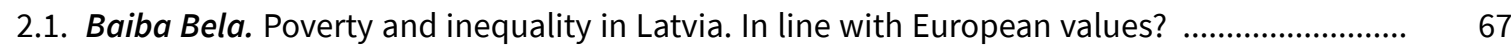

2.2. Aija Zobena. Opportunities and challenges of the Common Agricultural Policy for Latvia's rural areas

2.3. Klinta Ločmele. Not every tree in the forest stands tall: Europeanization of the media environment

2.4. Vita Zelče. European values and the Europeanization of Latvian society

\section{Appendicies}

Human Development Report social survey: technical information 


\section{Illustrations, tables, boxes}

\section{Illustrations}

Figure 1.1.1. Trust in political parties, Saeima and Cabinet of Ministers. 2004-2020

Figure 1.2.1. The dynamics in the number of civil servants in Latvia (2004-2019)

Figure 1.2.2. Number of employees in public administration compared with the total number of persons employed by the state as a whole (2019)

Figure 1.2.3. European administrative values

Figure 1.4.1. GDP per capita in constant prices (2011 US dollars), FSU countries, 1995 and 2018

Figure 1.4.2. GDP per capita, EU28, 2019, PPS adjusted, EU28 $=100$

Figure 1.4.3. GDP per capita growth in \%, constant prices, EU28, 2000-2019

Figure 1.4.4. Latvian exports and imports (goods and services) as \% of GDP, 1995-2019

Figure 1.4.5. Latvian exports of goods by major destinations, 1992-2018

Figure 1.4.6. Latvian exports of goods by selected major trading partners, 2000-2018

Figure 1.4.7. FDI stock in Latvia, end-2019, by countries

Figure 1.4.8. Latvia's structural budget balance, 2002-2019

Figure 1.4.9. Latvia's government budget balance and gross government debt, \% of GDP, 2000-2019. Budget balance on the first axis, debt on the second axis

Figure 1.4.10. Debt-to-GDP, 2019, EU28. Corona bond countries in dark blue, New Hanseatic League countries in blue

Figure 2.1.1. General governmental expenditure for social protection (2018) (\% of GDP)

Figure 2.2.1. Urban dwellers as a share of population in Latvia, Northern Europe, and Europe as a whole .....

Figure 2.2.2. Common agricultural policy: objectives

Figure 2.2.3. Latvia: number of people in rural areas/ cities at the beginning of 2020

Figure 2.3.1. Ranking of the Baltic States in the press freedom index of the organisation Reporters Without Borders (2013-2020)

Figure 2.3.2. Representation of the EU in thematic cross-section in the newspapers Diena and Latvijas Avizze August and 16-31 October 2019), $n=125$

Figure 2.4.1. Comparison of responses by Latvian inhabitants of different age groups to the question: "In your opinion, is the Holocaust seen in Europe as the ultimate crime against humanity?" (\%)

Figure 2.4.2. Comparison of responses by Latvian inhabitants with different levels of education to the question "In your opinion, is the Holocaust seen in Europe as the ultimate crime against humanity?" (\%)

Figure 2.4.3. Comparison of responses provided by Latvian inhabitants belonging to different age groups to the question: "In your opinion, are crimes against humanity perpetrated by the communist regime (i.e., the Soviet Union) condemned in Europe?" (\%)

Figure 2.4.4. Comparison of responses provided by various social groups of Latvia's inhabitants to the question: "In your opinion, are crimes against humanity perpetrated by the communist regime (i.e., the Soviet Union) condemned in Europe?" (\%)

Figure 2.4.5. Comparison of responses by age group of Latvia's inhabitants to the question: "In your opinion, is democracy a value in Europe?"

Figure 2.4.6. Comparison of responses by Latvia's inhabitants with different levels of education to the question: "In your opinion, is democracy a value in Europe?"

Figure 2.4.7. Comparison of the answers by social groups of Latvia's inhabitants to the question "In your opinion, is democracy a value in Europe?" 
Figure 2.4.8. Comparison of responses by various age groups of Latvia's inhabitants to the question: "In your opinion, is the European landscape - cities and countryside - well-maintained and beautiful?" ....

Figure 2.4.9. Comparison of responses by age groups of Latvia's inhabitants to the question:

"In your opinion, is Latvia a European value?"

Figure 2.4.10. Comparison of responses by social groups of Latvia's inhabitants to the question:

"In your opinion, is Latvia a European value?"

\section{Tables}

Table 1.1.1. European affairs executive coordination structures in the Nordic-Baltic Region

Table 1.1.2. Chairs of the European Affairs Committee (EAC). 1995-2020

Table 1.1.3. Latvian parties and their membership of Europarties and European Parliament groups in 2020 ...

Table 1.3.1. Financing for development cooperation: Latvia compared to Lithuania and Estonia. Data for 2018 and 2019

Table 1.4.1. Sovereign credit ratings for EU28 countries and for CIS countries

Table 1.4.2. EU28 and the Maastricht criteria, 2019

Table 2.1.1. Gini coefficient in Latvia and the EU (\%)

Table 2.1.2. The proportion of people at risk of poverty in Latvia and the EU (\%)

Table 2.1.3. Poverty risk indicators before and after social transfers

Table 2.1.4. Comparison of the lowest necessary net income for households to be able to make ends meet and income at households' disposal (EUR)

Table 2.1.5. Opinions of people in Latvia on the causes of poverty $(N=999)$

Table 2.1.6. Characteristics as to family composition of recipients of means-tested social assistance from local government, data for 2018

Table 2.2.1. Grouping of holdings according to the area of agricultural land (thousand ha)

Table 2.2.2. Balance of long-term migration of population: regions, cities and districts

Table 2.4.1. Values representing the EU (\%, maximum of 3 answers)

Table 2.4.2. Values of personal importance for Europeans (\%, maximum of 3 answers)

\section{Boxes}

Box 0.1

A short history of the Europeanization concept

Box 1.2.1. Consequences of Europeanization

Box 1.2.2. Agenda of the Senior Officials' Meeting convened on 20 May 2020 (Meeting of senior officials 2020)

Box 1.3.1. Basic principles of EU foreign policy in relations with Russia

Box 1.4.1. Year of Latvia's accession to major supranational organizations

Box 1.4.2. Latvia's sovereign rating with Standard \& Poor's ..

Box 1.4.3. The Maastricht (Convergence) criteria

Box 1.4.4. Major changes to the Law on the Bank of Latvia, following euro adoption

Box 1.5.2. Amendments of 8 May 2003 to the Satversme with respect to Latvia's membership in the EU

Box 1.5.3. The most relevant judgments of the Constitutional Court with respect to Latvia's membership in the EU 
Box 2.2.1. The EU Common Agricultural Policy .

Box 2.3.1. Aims for freedom of the media advanced by the EU

Box 2.4.1. Marginalia or comments on Czesław Miłosz's poem "A Child of Europe" (1946) by translator Uldis Bērzinš̌ in 1991

Box 2.4.2. European Union values

Box 2.4.3. Speech by President Vaira Vīke-Freiberga at the official ceremony of the accession of Latvia to the European Union in Riga's Dome Square on 1 May 2004

Box 2.4.4. Member of the European Parliament Sandra Kalniete on the House of European History 


\section{Basic facts about Latvia, 2019}

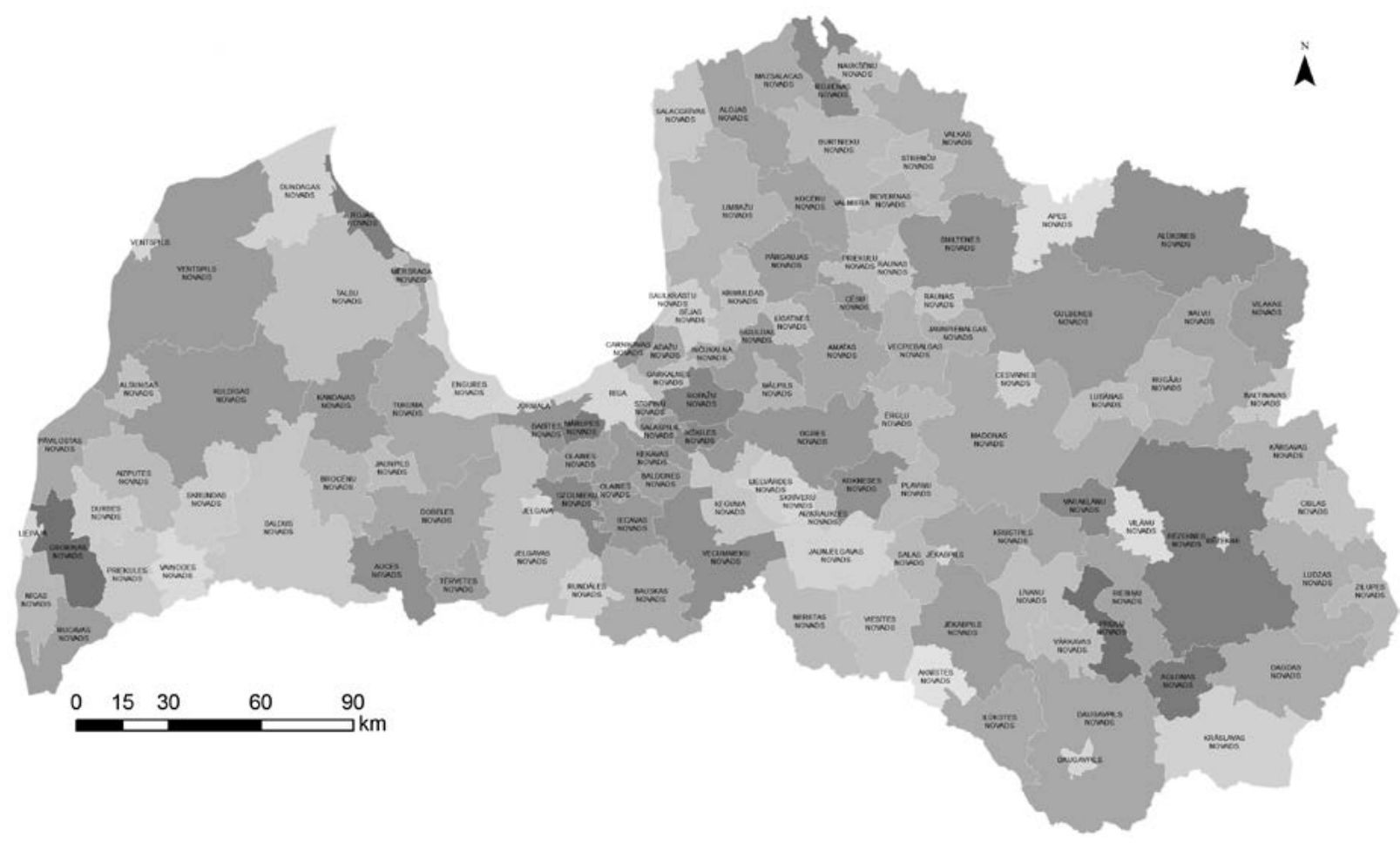

Population

Number of inhabitants, millions $\quad 1.9$

Natural population growth, \% $\quad-0.5$

Population density, person per $\mathrm{km}^{2} \quad 30$

Gender distribution of population, $\%$

Males

46

Females 54

Ethnic distribution, \% (at the beginning of the year)

Latvians 62

Russians 25

Belarussians 3

Ukrainians 2

Poles 2

Lithuanians 1

Others 5

Economy

Gross domestic product, millions of euro 30,476.1

GDP per capita

In constant prices of 2010, euro

14,371

GDP per capita

According to purchasing power level

Growth of GDP, \%

15,930

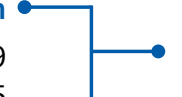

- Population distribution between

urban and rural areas, $\%$

$\begin{array}{rr}\text { Rural } & 31 \\ \text { Urban } & 69\end{array}$

Age distribution of population, $\%$

Urban

69

(at the beginning of the year)

Below working age (0-14 years)

Working age

Above working age

15.9

61.3

22.8

Human Development Index Rank

(Human Development Report 2019)

Human development index $\quad 0.847$

Adult literacy rate, \% 99.9

Unemployment rate, \% 6.2

Distribution of employment by sectors, $\%$

$\begin{array}{rr}\text { Agriculture } & 7 \\ \text { Industry } & 24 \\ \text { Services } & 69\end{array}$

Euro rate versus 1 USD

(at the end of 2019) - 1.185

Health

Average life expectancy (years)

75.6

Males $\quad 70.8$

Females $\quad 79.9$

Infant mortality per 1000 live births $\quad 3.4$

Number of physicians per 10000 inhabitants $\quad 33.2$

.2

.2

General government sector expenditure, $\%$ of GDP (2018) 


\section{Introduction}

\section{Daunis Auers (\& Ivo Rollis)}

The 2020/2021 Latvian Human Development Report takes stock of the impact of European Union (EU) membership on Latvia's state, economy and society. The focus is on the effect of the EU on Latvia, a top-down approach, rather than a study of Latvia's impact on the EU, and the 2020/2021 Latvian Human Development Report's broad team of authors have concentrated on the fifteen-plus years of membership in the EU rather than the reforms and changes that were introduced as part of the accession process. ${ }^{1}$

Membership of the EU was a much anticipated event. After seizing de facto independence Latvian politicians had three core foreign policy options - to lean towards the east, to lean towards the west, or to attempt a tricky neutral balancing act. In truth, there was almost no mainstream support for the former or latter options. All post-independence governments in Latvia have had a pro-western foreign policy orientation, with membership of both the EU and NATO seen as the central tenets of foreign policy. Membership may have seemed like a remote ambition in late 1991, as the newly sovereign Latvia faced the mammoth tasks of economic reconstruction and democratization while at the same time a sizeable Russian military force, estimated at over 50,000 men, menacingly remained posted on Latvian territory. These forces did not withdraw until August 1994, while Russia did not fully hand over the Skrunda radar station to Latvia until 1999.

The road to eventual EU membership was rocky and took almost thirteen years, far longer than had been initially expected. After all, the background conditions for EU membership had initially appeared quite favourable. Latvia was among the most developed Soviet republics, with a high rate of industrialization, a well-regarded three-tier education system, especially in mathematics and the "hard" sciences, and a broad logistics infrastructure encompassing roads, railways, ports and the biggest airport in the Baltic region. However, all this was to prove somewhat of a potemkin facade. While the three Baltic States were economically developed by comparative Soviet measures, their economies lagged far behind the West. Comparisons between East and West at that time were difficult due to incompatible and often unreliable data, but in 1991 the Research Institute of the Finnish
Economy calculated that, based on 1988 data, the average Finn was 8.4 times wealthier than the average Estonian, despite broadly similar levels of income in 1940 before the Baltic states were occupied by the Soviet Union (Baltic Independent 1991). Much of the industrial goods produced in Latvia were of a shoddy quality and failed to find Western markets. Enterprises were difficult to reform as Latvian universities had no experience teaching business, market economics, public administration and other social sciences. While the port and logistics infrastructure proved to be a profitable source of tax income in the early years of investment, roads were pot-holed and unsuited to intensive lorry traffic while the airport was actually little more than a runway. As a result, the depth, scope and time for reforms proved much more extensive than initially expected. Nevertheless, in May 2004 all three Baltic states joined the EU together with five central European and two Mediterranean states. This Human Development report explores what happened next.

\section{Latvia's road to the EU}

18 June 1994, Latvia signs Free Trade Agreement with the EU

12 June 1995, European Association Agreement signed with EU

27 October 1995, the Latvian government submitted a formal application for the EU membership.

15 July 1997, the European Commission delivered an unfavourable opinion on Latvia's readiness to open accession negotiations with the EU

13 October 1999, the European Commission adopted a favourable decision

15 February 2000, accession negotiations opened

13 December 2002, the accession negotiations were completed

16 April 2003, Latvia signed the treaty on Latvia's accession to the EU

1 May 2003, Latvia started participating in the work of the EU institutions as an observer

20 September 2003, referendum on Latvia's membership of the EU with $67 \%$ voting in favour

1 May 2004, accession to the EU

The impact of Latvia on the EU (as well as the reverse impact of the EU on Latvia) was considered in a 2019 edition of "Latvia's interests in the EU" by a team of researchers including Aldis Austers, Daunis Auers, Inna Šteinbuka and Žaneta Ozolina (2019). 
The 2020/2021 Human Development Report team of authors explores the impact of the EU on Latvia through the "europeanization" theoretical concept. Ivo Rollis, who has written a $\mathrm{PhD}$ thesis on europeanization, provides a short history of the evolution of the europeanization concept in Box 0.2. In short, europeanization which generally refers to the impact of the EU on nation states - is a fast growing and dynamic area of multi-disciplinary social science study. It has gained in salience as the major EU treaty reforms of the 1990s (the Maastricht Treaty, the Treaty of Amsterdam and the Treaty of Nice) expanded the scope of EU policies and policy areas and led to the EU leaving an increasingly large footprint on the political system, economy and society of the member states. In this volume we have adopted Robert Ladrech's broad definition of europeanization as the "process of domestic adaptation to the impact of the EU within member states" (Ladrech 2010: 1). This definition both reflects europeanization's relatively fuzzy concept and allows the multidisciplinary team of authors to consider both direct and indirect europeanization influences on their different areas of study.

\section{Box 0.1}

\section{A short history of the Europeanization concept}

\section{Ivo Rollis}

Europeanization could be characterised as structural changes with diverse impacts on different state institutions and participants in political processes: their functions, ideas, interests, and values. Europeanization is linked to Europe and its development, most often to the influence and interaction of the various policies of the European Union (EU) and its nation states, in particular the executive powers and their response to proposed changes (Ladrech, 2010). Until 1980, the term "Europeanization" was mentioned in the academic literature of political science only occasionally, but an understanding of the concept of Europeanization gained relevance with accession to the EU by the states of Central and Eastern Europe (CEE) and compliance with the conditions set for them (Featherstone and Radaelli, 2003).

Several lines of discussion on Europeanization can be identified in the academic literature (Ladrech, 1994, 69-88). First, the term "Europeanization" is commonly used to examine the impact of the EU upon Member States, which probably could be better described by using the term "EU-ization". Thus, with the EU as the place where exchange of political ideas and practice is promoted, the issue of the EU's role as a source that facilitates change is advanced for discussion. Secondly, regarding the separation of Europeanization from European integration, these are not synonyms each comprises a different political process. European integration is preoccupied with political issues and policy development on the supranational level, whereas Europeanization is interested in the consequences of that process, mainly with respect to the EU Member States and their policies. Thirdly, the subjects of executive powers in the EU Member States are totally passive with respect to Europeanization but rather respond to the formation of integration or policies (Börzel, 2002, 193-194; Bulmer and Lequesne, 2005, 10).
The historical understanding of the term "Europeanization" is also linked to the export and control of social norms, organisation and practice of institutions, social and cultural views, values, and behaviour. In its historical understanding, Europeanization has often meant adjustment to Western European norms and practices. In a cultural understanding, Europeanization meant the emergence of a supranational culture - the merging of those cultural norms, ideas, conditions of identity and conduct that are based on supranational foundations in Europe. In the cultural meaning, Europeanization has extensive application, for instance in discussing changes in the habits of celebrating festivities. Europeanization also impacts broader social activities, such as education. However, this term is usually applied to characterise changes in political culture or ideology. The historical and cultural approach can be indirectly linked to the direct impact of the EU, whereas institutional and policy and policy adjustment approaches are more recent and applicable to the minimal understanding of Europeanization, since it most directly affects institutional aspects in terms of the functioning of the EU, comprising responses by states to EU policy.

At the end of the $20^{\text {th }}$ century, authors describing the definition and concept of Europeanization focused on processes ongoing at the supranational level, whereas national- and local-level political, economic and social changes dominate in theory. A similar shift of emphasis has occurred from formal institutions and processes of institutionalisation to the participants in these processes, their actions, understandings, perceptions, discourses, and cultural particularities (Grunhut, 2017, 171). In the academic literature, Europeanization and its effects are in particular examined in researching national-level institutions, policies and their outcomes in states or issues of the impact of Europeanization and processes of national adaptation to the EU (Goetz, 2000, 222). 
Adaptation is determined by the need to attain successful interaction with the existing EU order. In turn, assessment of the effects of Europeanization allows attribution of changes which have actually been caused by other factors. For example, the policies of particular EU Member States may be explained by Europeanization; however, they may also be based on previous reforms or even the impact of globalisation. Striving for compliance with EU rules also fosters close interaction with globalisation as a process, which can be used as attribution for a more extensive explanation of significant changes in the policies and societies of individual states.

Since the end of the 1990s, the term "Europeanization" has also been used to include one of the forms of the most direct effects of Europeanization on the Member States and candidate countries, as well as in important areas of national development related to that effect. Europeanization is based on the idea that European integration has become so deep in terms of its impact that national-level processes are fully integrated into extensive, European-level development. In the academic literature, Europeanization has been discussed not only as a process in which the EU disseminates its policies or in which the candidate countries move towards EU policies, but as an outcome - the degree of policy coherence with the EU. When the process of accession to the EU begins, Europeanization turns into the main priority for a candidate country. The EU demands proposals from states regarding policy implementation in those policy areas to which EU rules and accession terms apply. Adoption of EU policy becomes mandatory, at the same time absorbing the process of national policy formation (Matlak, Schimmelfennig and Wozniakowski, 2018, 8).

Institutions of power, policies, politics and outcomes in terms of impact on the national level are features that characterise Europeanization. These are the main categories that allow analysis of the Europeanization of EU Member States and changes on the national level. Although, from the research perspective, separation of these categories would be expedient, in practice, however, European politics, processes and institutions simultaneously influence not only one but sometimes all three categories. In the academic literature, a series of mechanisms has been identified that the EU can use to influence Member States, thus decreasing incompatibility between European and national policies, processes and institutions (Bulmer and Lequesne, 2005, 51). Research on the direct and indirect effect of the EU on national-level political systems began even during the period when the countries of CEE were acceding to the EU (Goetz and Hix, 2001; Kassim and Menon, 2003; Kassim, Peters and Wright, 2000; Laffan, 2003). Part of Europeanization literature that studies the effect of the EU on institutions of executive power mainly focuses on the organisations and procedural structures at the centre of government that coordinate national positions on EU matters. The share of top-down analysis has increased "assessing the impact of governance systems at European level on Member States (dimensions of change at national level), how the EU affects Member States (mechanisms for change at national level) and what is the impact of the EU on Member States (results of change at national level)" (Bulmer and Lequesne, 2005, 260-261; Cowles, Caporaso and Risse, 2001). This, in particular, has been applied to adaptation of the national-level system of public administration for preparing for EU membership and conducting negotiations on accession to the EU. Less attention has been paid to Europeanization of politics and Europeanization of the participants in political processes - society, political parties, and interest groups (Sedelmeier, 2011, 20), while economic and social Europeanization has played an even smaller role in the original concept of Europeanization and research (Epstein and Jacoby, 2014, 7).

One more approach to studying Europeanization has emerged as a result of institutionalists' analysis. Institutionalists' approach is used by such researchers of Europeanization as Tanja A. Börzel, K. M. Radaelli and John P. Olsen. Olsen notes that the institutionalists interpret external changes and their effect and view them through the institutional framework existing in the state, including existing normative views on legitimate institutions and proliferation, use and control of power (Olsen, 2002, 933). The Europeanization literature that analyses the Western EU Member States emphasizes that the institutional and policy outcomes caused by EU enlargement have been attained much more quickly in EU Member States from CEE. The institutional factor is mentioned as the cause, in the shape of the weak centre of executive government in CEE/EU Member States, in particular in those that returned to the political map at the beginning of the 1990s. These countries were less reserved towards pressure to adapt compared to strong public institutions with rich traditions in the prosperous West European states. Almost all CEE Member States of the EU experienced an operational and legitimacy crisis of national institutions, which encouraged them to adopt some successful and also less successful policies and to study the experience of other countries.

Due to lack of effective institutional systems and policies, Europeanization fostered not only the process of adaptation but also the evolution of new institutions and policies in the CEE Member States of the EU. Researchers tended more often to examine Europeanization in the context of Europe's impact on the national and political system. This is linked to differences in the transposition of European policies, in particular EU directives, in the EU Member States. Researchers analysed countries' administrative adaptation to EU membership, transposition of directives, as well as changes in the structure and identity of the national state, taking into account European-level changes. In specific cases, these changes could lead to policy and institutional changes, but another time development of resistance by national-level participants, thus permitting only limited changes. These and other issues entered the 
new agenda for researching Europeanization of CEE Member States of the EU, Latvia among them. Leading researchers of Europeanization joined forces to develop a new, unified academic agenda for researching issues of Europeanization (Graziano and Vink, 2007). To a large extent, these efforts were linked to the fact that early Europeanization research mainly strove to conceptualise Europeanization and develop a theoretical framework, as well as offering various case studies. Other studies, in turn, focused on a broad range of issues - from studying the system of parties to various policies, for example, refugee policy.

However, research on the EU relationship with CEE has three substantial limitations. Firstly, in the case of CEE Member States of the EU, until now the conceptual framework of Europeanization has been examined empirically, mainly from the administrative or public administration perspective - analysing how the public administration systems of these states prepared for accession to the EU so that they would comply with specific adaptation requirements as well as forecasting the long-term administrative effect of EU membership. Secondly, the studies have mainly focused on the stage of accession to the EU, an objective reason for which is the accession of many new states to the EU in 2004. The third limitation is linked to the dominant research framework "Europeanization East" (Schimmelfennig and Sedelmeier, 2005, 3). Within that framework, researchers have mainly focused on EU enlargement negotiations, reform processes in the candidate countries (Schimmelfennig and Sedelmeier, 2002), the progress made by future EU states in taking over and transposition of EU policies and legislation (Schimmelfennig and Sedelmeier, 2005), consequences of EU enlargement, EU administration, and analysis of candidate countries' governments (Lippert and Umbach, 2005). The academic discussion on "Europeanization East" has emphasised adaptation to EU requirements, focusing on the effect of EU conditionality on the EU candidate countries and Europeanization of the executive powers of the states that acceded to the EU in the enlargement period of 2004. Research related to the period of states' membership in the EU has mainly focused on the effectiveness of EU institutions and of processes related to their functioning.

The excessive focus placed by researchers of Europeanization on the adaptation effect of the EU has prevailed over the need for more attention to a comprehensive assessment of the functional independence and ability to adapt by the national-level institutions in CEE countries. Research on Europeanization in the CEE Member States of the EU also differs, methodologically and theoretically, from research on the West European Member States of the EU (Gwiazda, 2002). In the process of acceding to the EU, CEE was in a totally different situation. Never before in history did domestic policy changes have so many sources of external effects as in the transitional process of democracy of CEE states. Initially, matters of changes in the public administration of CEE countries were examined in the context of influence exerted by powerful international organisations such as the EU, the World Bank, the International Monetary Fund, the Council of Europe, the Organisation for Security and Cooperation in Europe, and the North Atlantic Treaty Organisation. However, gradually more attention was paid to the way Europeanization functions on the national level.

With enlargement and development of the EU, the level of development and Europeanization of national policies has increased. Accordingly, Europeanization also foregrounds issues of interaction between social and political processes, changes in identity, their impact on policy and society in accordance with EU development, which, in CEE Member States, is also important in the common context of European integration. In the case of CEE EU Member States, research so far conducted by representatives of social sciences on some social consequences suggests that scenarios for development of public opinion and the economy have been fragmented. This limitation has been the main reason for criticising the approach to analysing Europeanization. Currently, in the agenda of Europeanization research, expansion of the geographical space of research towards the countries of the Western Balkans and Eastern Europe should be taken more into account. Researchers have started to expand the research area since the countries in these regions have become interesting to them, for instance because differences compared to Western Europe can be observed, for example in institutional stability and other trends in the development of Europeanization within the structures of state power, the economy, and society.

\section{Structure of the report and key findings}

Membership of the EU was expected to bring three broad benefits to Latvia. First, modernization, and an accelerated "de-Sovietization", of the state. Second, swift economic growth that would see Latvia eventually catch-up with the older West European member states. Third, a more diffuse anchoring of Latvian identity and values in the West. All three dimensions are covered in this volume.

The first part of the 2020/2021 Human Development Report delves into change and modernization of the state by focusing on the europeanization of the political system, public administration and local government 
as well as foreign affairs and the court system. It also considers the impact of the EU on the economy.

Daunis Auers' first chapter focuses on the europeanization of key political institutions and actors. The executive and the legislature were among the first institutions to feel the stress of the accession process and then later membership of the EU, as both bore the brunt of first adopting the acquis communautaire to Latvian law and then, after 2004, of both top-down transposing of EU law and bottom-up processes of forming national positions and shaping legislation at the European level. New institutions and coordination mechanisms were set-up in the executive and a powerful European Affairs Committee created in the Saeima, although the latter is hampered by time pressures and a dearth of institutionalized analytical capacity. Political parties and interests groups have adapted their organizational structures and have almost daily interactions with their European partners. Only the office of the president of Latvia has seen a decline in the salience of European affairs following accession.

The EU has also had a considerable direct and indirect impact on Latvia's civil service. Iveta Reinholde's chapter explains how intensive pan-European cooperation has seen Latvia's civil servants adapt their values - such as the rule of law, transparency and responsibility - and working patterns to gradually converge with their European partners which has, in turn, led to the expected modernization of the bureaucracy. Inevitably, there has also been a europeanization of policy while local governments have also seen the relevance of European issues - especially in terms of access to European funds increase. Looking to the future, Reinholde recommends more ex-post analysis of European legal acts as well as a renewed focus on explaining the value and importance of this legislation to Latvia's population.

Toms Rostoks focuses on the europeanization of Latvia's foreign policy. After reviewing the relevant literature, explaining how membership of the EU has impacted Latvia's diplomatic service and outlining changes in the size of Latvia's permanent representation in Brussels (COREPER), Rostoks examines how europeanization has affected Latvia's relations with Russia, Latvia's role in the Common Foreign and Security policy (CFSP) and how membership of the EU has impacted Latvia's development cooperation strategy and policies. Rostoks points out that the EU has had but a limited impact on Latvia's relations with Russia (where the last fifteen years has seen the EU shift closer to Latvia's position rather than vice versa) and Latvia's development policy, but that there has been a significant institutional impact as well as change in how society views foreign policy, perhaps seeing it in more European than domestic terms. Rostoks recommends strengthening both professional and research capacity in the foreign affairs sector, in order to allow Latvia to embrace the opportunities of European foreign policy making more fully.

Membership of the EU was also seen as a powerful driver of future economic growth. Valdis Birkavs (who held the post of prime minister in the critical 1993-1994 period) argued that the Latvian public had only a vague, blurry understanding of the EU generally seeing it as the opposite of the poverty and backwardness of the Soviet Union:

"The foggy impression that people in Latvia had about the EU can only be compared with paradise... the empty shelves in Soviet shops turned the plenty in the West into the Garden of Eden. The slogan 'in bare feet yet free' presumed that there would be an opportunity to buy better shoes" (Birkavs, 2016: 44)

Morten Hansen, a Danish economist at the Stockholm School of Economics in Riga who has witnessed firsthand the economic impact of Latvia's accession and membership to the EU in the quarter century he has spent teaching in Rīga, tackles the difficult task of evaluating the EU's role in reshaping the Latvian economy since 2004. Hansen points out that the economies of Latvia and the other two Baltic states have far outperformed the other post-Soviet states in this period. However, Latvia remains among the poorer EU member states with a GDP per capita at just $69 \%$ of the EU27 level in 2019. The impact of europeanization is felt more at the legislative and governance level, with changes to the Bank of Latvia Law, observance of the Maastricht criteria, the establishing of the Fiscal Discipline Council and in economic policy. The EU has transformed economic governance in Latvia. However, Hansen points out, the EU can have little impact on raising Latvia's GDP - creating a more competitive economy is in the hands of Latvia's politicians and policy-makers.

Jānis Pleps, a leading constitutional scholar, analyses the europeanization of the Latvian constitution and the Constitutional Court. Pleps explains that the transformation of the Latvian justice system coincided with Latvia's accession to the EU, meaning that europeanization impacted almost every part of Latvia's justice system. This has resulted in a Constitutional Court that is a keen supporter of EU law and in the future is well poised to play a greater role in shaping the European justice system.

The second part of the report focuses on the impact of the EU on people, society and the media. First, Baiba Bela discusses developments in poverty and inequality in Latvia, investigating the extent to which Latvia's the EU has influenced changes in Latvia's social protection system. Bela shows that while social issues have increasingly appeared on the EU agenda in the twenty first century, they have never been a primary concern for Latvia's policy makers. As a result, the number of people living in poverty and the rate of inequality is well above the EU average and membership of the EU has done nothing to change this trajectory.

In the following chapter Aija Zobena investigates rural development after 2004. Zobena outlines key rural development trends - a falling number of agricultural workers, 
declining rural populations, rising inequality between larger and smaller farming units, and a fall in the quality and scope of public services in rural areas - as well as the impact of the Common Agricultural Policy (CAP) on rural regions and farming families. CAP has succeeded in bringing investment to Latvia's rural regions but Zobena points out that it has failed to reach all the potential target groups, meaning that a significant section of Latvia's rural population is increasingly left behind.

Klinta Ločmele looks into post-accession developments in Latvia's media landscape. The EU has undoubtedly had a significant impact on the regulation of media in Latvia, modernizing legislation covering advertising and other important, and deeply politicized, issues that had been largely ignored in previous years. International contacts and support for free speech and the media's critical role in a democracy from European institutions likely helped Latvia to rapidly rise in international rankings of media freedom. At the same time, however, Ločmele stresses that while many key challenges still remain -advertising revenue flowing away from traditional media towards a social media which pays little, if any, taxes in Latvia, as well as threats to democracy from "fake news", to give two examples the EU has an important role to play in helping Latvia and other EU states to successfully tackling these challenges.

The Human Development Report concludes with a chapter reflecting on europeanization, values and society. Vita Zelče points out that a sense of both Latvian nation and state belonging to Europe, rather than the "East", was one of the driving factors for the Latvian independence movement in the 1980s. But have Latvians adopted "European" values and attitudes after three decades of sovereign independence? Zelče explores the development of Latvian attitudes on history, contemporary European values as well as postmodern values through national survey data prepared for this Human
Development Report and Eurobarometer data. Although key European values of human rights, peace and individual freedom have taken root among Latvia's public, Zelče finds that the biggest barrier to value convergence remains Latvia's comparatively lower level of economic development as well as entrenched poverty and inequality.

The 2020/2021 Latvian Human Development Report demonstrates that there are areas where europeanization has had a profound effect on Latvia and others where the influence is more minimal. The impact of the EU has been keenly felt in key political institutions, with government ministries and agencies, the Constitutional Court, parts of the Latvian legislature, the Bank of Latvia and other institutions now cooperating with EU institutions and European partners on a daily basis. Membership of the EU has led to a broad modernization and general restructuring of government in order to deal with the strains of transposing European law and participating in European-level policy-making through the formulation of national positions. Political parties, interest groups, civil servants and local governments are now more outward-looking than they were in 2004 and interaction with European partners is a regular, every-day part of their working lives. While there has been a broad societal shift to supporting more "European" values, membership of the EU has not led to any significant positive developments in tackling Latvia's entrenched poverty, inequality and rural decline. These, just like economic development, are essentially national issues that can only be tackled by national reforms undertaken by national governments. Europeanization has its limits. Laws can be remade, institutions opened up and modernized, multiple international links formed, European funds invested in infrastructure and farmers supported. But national political priorities remain in the hands of domestic politicians and policy-makers. 


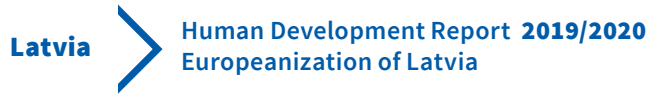

\section{Part 1}

\section{Politics, law and the economy}

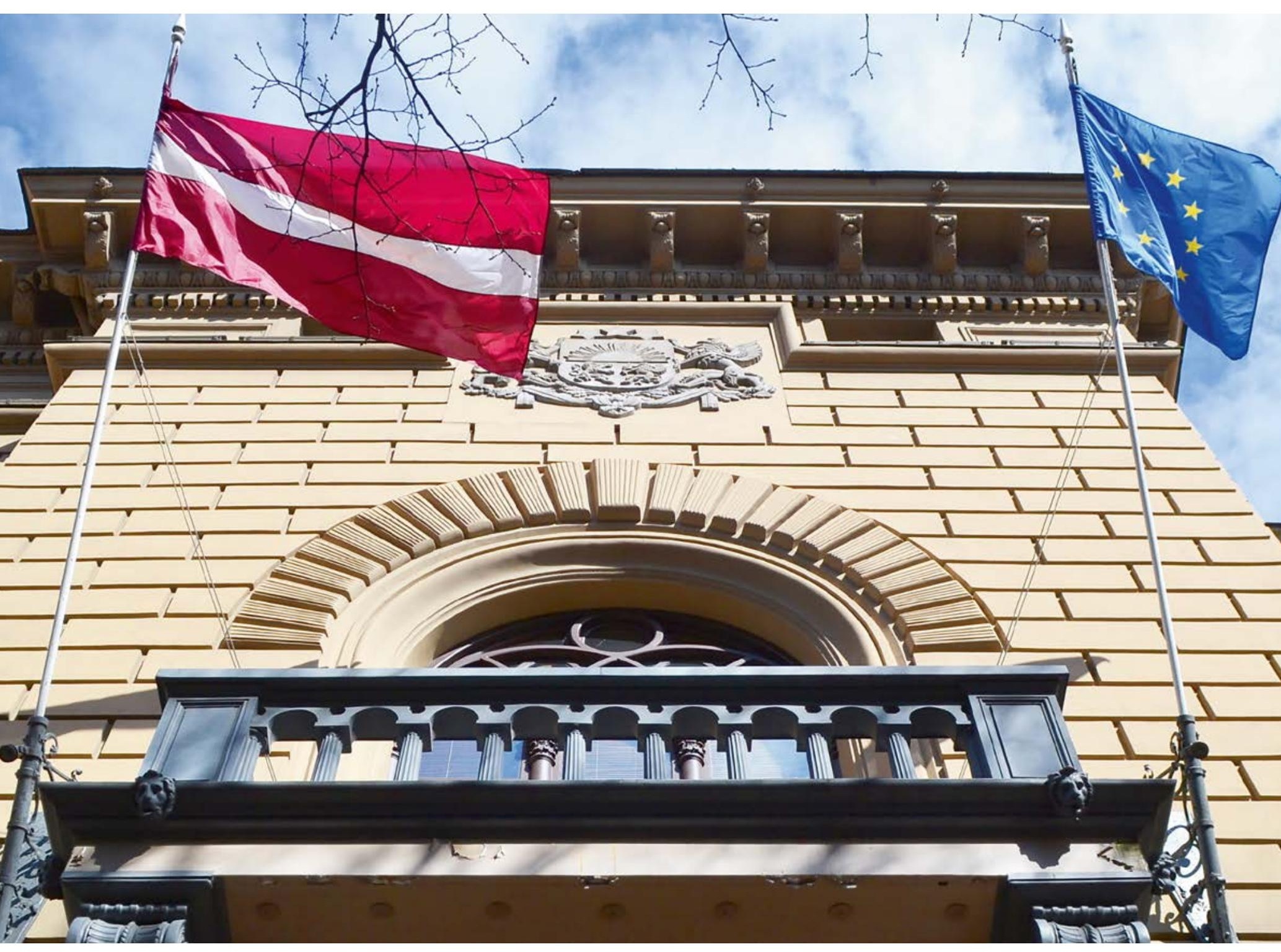




\subsection{Europeanization of Latvia's political system}

\section{Daunis Auers}

\section{Introduction}

This chapter considers the impact of the European Union (EU) on the domestic Latvian political system. A considerable European influence was already felt before membership, as both government and parliament felt the strain of adopting the tens of thousands of pages of the acquis communitaire body of European law as well as reorganizing or setting-up new political institutions as a crucial part of the integration process. Latvia's relationship with the EU then fundamentally changed after May 2004 as it went from being a "third country" with bilateral relations with the EU to being one of a growing number of full-fledged member states that was no longer purely reactive to EU demands but expected to take initiative and promote its own national interests. As a result, over the last decade and a half EU decision-making has become entrenched and routinized in domestic politics and the day-to-day work of national government.

The first two sections of this chapter consider significant and far-reaching changes in executive-legislative relations. Membership of the EU generally strengthens the political executive and weakens parliament. Has this also been the case in Latvia? How does the executive coordinate and manage EU issues and how does parliament execute oversight? The next section briefly examines the more limited europeanization of the Latvian president's office. The final two sections focus on the primary actors in the Latvian political system - political parties and interest groups - and assess the significant organizational adaptation that they have undergone since 2004. The conclusion reflects on the broader impact of the EU on Latvian politics and the public response, or lack of response, to these changes.

\section{The Executive}

Membership of the EU does not in itself demand any specific reform or reshaping of the national executive. However, the challenges of accession and membership means that some sort of institutional adaptation is inevitable. This is driven by two factors. First, states seek to be more effective in influencing the European policy-making process. Second, states need to adapt to the challenge of implementing European legislation. Member states typically address these challenges in two ways. First, by identifying and then diffusing key national interests to all levels of the public administration. Second, by creating an inter-ministerial coordination structure that manages inputs from the European level and develops national negotiation strategies.

Latvia does not have a single document that identifies its medium- or long-term national interests in the EU. Rather, there are a number of documents that lay out short-term interests. The three key documents are (i) the Foreign Ministry's annual report on what has been achieved, and what is to be done, in foreign affairs, (ii) an annual list of priorities in the EU for a calendar year and (iii) coalition declarations that typically contain sections on the EU. ${ }^{1}$ On the one hand, Andris Gobinš, the president of the European Movement in Latvia, has been critical of this ad-hoc approach, arguing that Latvia would benefit from the predictability and stability of a single medium- or long-term strategy document that remains unaffected by the political vagaries of changing government coalitions (Gobinš interview, 2019). This has been the practice in Estonia. ${ }^{2}$ On the other hand, key Latvian foreign policy makers support the ad hoc Latvian approach, arguing that it allows for greater flexibility in today's dynamic and fast-changing international environment (Lukaševica-Kalniņa interview, 2019). It also, of course, gives key decision-makers, particularly the prime minister and foreign minister, greater freedom and elasticity in shaping policy.

\footnotetext{
1 The most recent Ministry of Foreign Affairs report (Ārlietu ministra ikgadējais ziņojums par paveikto un iecerēto darbību valsts ārpolitikā un Eiropas Savienības jautājumos 2018.gads) can be found here: https://www.mfa.gov.lv/images/ministrija/Arpolitikas zinojums_2019.pdf . Annual priorities (Latvijai prioritāri Eiropas Savienības jautājumi 2020. gadā) are listed here: https://www. mfa.gov.Iv/arpolitika/eiropas-savieniba-arpolitika/latvijas-prioritates-es The January 2019 government declaration (Deklarācija par Artura Krišjānna Kariṇa vadītā Ministru kabineta iecerēto darbību) is here: https://www.mk.gov.lv/sites/default/files/editor/kkvaldibas-deklaracija_red-gala.pdf.

2 See, for example, “Estonia's European Union Policy 2015-2019”. https://www.riigikantselei.ee/sites/default/files/content-editors/ Failid/eesti_el_poliitika_eng.pdf
} 
Table 1.1.1. European affairs executive coordination structures in the Nordic-Baltic Region

\begin{tabular}{|c|c|c|c|}
\hline \multirow{2}{*}{ Country } & \multicolumn{3}{|c|}{ Coordination structure } \\
\hline & Separate Institution & Foreign Ministry & Prime Minister \\
\hline Denmark & \multicolumn{3}{|c|}{$x$} \\
\hline Finland & & & $x$ \\
\hline Sweden & & & $x$ \\
\hline Estonia & & & $x$ \\
\hline Lithuania & & $x$ & \\
\hline Latvia & & $x$ & \\
\hline
\end{tabular}

EU member states tend to adopt one of three different coordination models. The earliest model saw European issues coordinated through national Ministries of Foreign Affairs and many older states, such as the Netherlands, still have this model, albeit with the caveat that there is often a junior minister with responsibility for EU affairs assisting the Foreign Minister. As the complexity of the EU grew, member states like France elected to centralize EU affairs into the office of the Prime Minister ensuring greater political support for EU positions and, some scholars argue, greater efficiency (Dimitrova, 2002). The third model is to create a separate institution, a Ministry of Europe or similar government structure, charged with coordinating EU issues. This, however, is an option rarely used. Of the new member states joining the EU after 2004 only Romania and, very briefly, Lithuania, have had this model.

The trend over the last twenty years has been to move away from the Foreign Ministry model and towards greater prime ministerial involvement. Latvia, however, has resisted this trend and instead the Latvian Foreign Ministry's EU Coordination and Policy Department is the key institution overseeing and coordinating the system. This model seems well suited to Latvia because the post of the Foreign Minister is comparatively stable. For example, by 2020 Edgars Rinkēvičs had served as Foreign Minister for nine years (since October 2011), in six government coalitions and under four different prime ministers. As Table 1.1 shows, the NordicBaltic Six (NB6) states are evenly split in adopting the prime ministerial or foreign ministry coordinating EU policy model, thus there is little external pressure to adopt a different system.

Another sign of executive adaptation to Europe is the formation and embedding of specialized EU policy administrative units within sectoral ministries, providing ministry's with experienced expert advice in both implementing EU laws and shaping national preferences. Membership of the EU has also significantly expanded the executive's scope of activity and responsibility, with ministers (and parliamentary secretaries, who are junior ministers in all but name) regularly participating in shared decision-making at the Council of Ministers in Brussels and prime ministers working with their peers in the European Council. The travelling and time that these meetings take up is a significant additional burden to the work of ministers. In the first eleven months of Krišjānis Kariņš' prime ministership (February-December 2019), there were six regular and "special" meetings of the European Council as well as two informal meetings of the heads of EU governments (European Council Meeting Calendar, 2020). Moreover, prime ministers (and ministers) are also now expected to be fluent in English in order to be able to exert backroom influence at European Council meetings. In February 2016, for example, former president Vaira Vīkse Freiberga reprimanded Prime Minister Maris Kučinskis, who had admitted that he was more fluent in German than English, and encouraged him to take English language lessons (Pētersone, 2016).

Membership of the EU has clearly had an impact on the structures and working practices of the executive. The creation of new EU units, inter-ministerial institutions aimed at smoothing coordination of EU issues, as well as the executive's permanent representation (COREPER) in Brussels, has led to a growing number of expert European resources for the executive. Moreover, as previously domestically controlled issues (such as competition policy, agricultural subsidies and single market rules) are transferred to the European level, the executive retains some sort of influence over the shaping of these policies through its seat on the Council of Ministers. In contrast, national parliaments have no such direct role in the legislative process. As a result, scholars have observed that one unintended outcome of the Europeanization process is a strengthening of the executive and a weakening of the legislature (Maurer and Wessels, eds, 2001). 


\section{The Legislature}

National parliaments have been identified as losers from the European integration process because of their marginalization from European decision-making processes. Member state legislatures also tend to have more limited expert and research resources which reduces their oversight and scrutiny powers. The Lisbon Treaty attempted to reverse this process by granting national parliaments new powers as part of a broader effort to democratize the EU. European legislatures can now scrutinise, review and object to draft legislative acts, based on the subsidiarity principle, as well as promote dialogue with the European Commission and deepen interparliamentary cooperation with the European Parliament.

The most direct impact of the EU on the Saeima is the establishment of the European Affairs Committee (EAC) as a permanent committee in 1995 by the outgoing western-leaning parliament that had been elected in 1993. EAC's initial task was to oversee the harmonization of Latvia's laws with the demands of EU membership, but it was also intended as an anchor to Latvia's western foreign policy trajectory (Ikstens 2014). Since 2001 EAC has been parliament's official representative on all EU issues, thus giving the Committee a broad mandate.

The EAC's key power is ex-ante oversight and approval of national negotiating positions before they are presented at the Council of the EU and the European Council. EAC decisions are binding on the cabinet. ${ }^{3}$ This places EAC among the more powerful parliamentary European Committees in Europe. However, there is an obvious disequilibrium between the resources available to the executive and those available to the legislature. The current (2020) and previous chairs of the EAC both identified two key resources that the committee lacks time and lack of analytical capacity (Čigāne interview, 2019, and Tērauda interview, 2020). The time issue is built into the system, with national positions coming up for parliamentary scrutiny close to the time of the relevant European meeting, meaning that members of the EAC often lack the time to delve deeper into the position, not least because each Saeima deputy has but one assistant who, due to the low salary, tends to be, at best, an early career professional. The EAC, as with every parliamentary committee, has dedicated consultants, but they can hardly be expected to be experts in all the many different EU policies (agriculture, the EU budget (annual and multiannual), competition, environment, research and innovation etc.) in which the EAC must approve the national position.

The EAC, as with the Latvian parliament more broadly, also lacks access to analytical resources (Kalniņš 2019). The Saeima's Analytical Service only began operating in 2017 and in 2020 employed just four people with limited additional funds to purchase external expertise. A recent analysis of parliament's analytical capacity found that "the Saeima has a grossly inferior analytical capacity compared with the executive... it causes concern regarding the Saeima's ability to screen executive policy initiatives critically and fully carry out parliamentary oversight regarding the government" (Kalniņš 2019.) EAC did not even apply for an Analytical Service research service project in 2020 (Tērauda interview, 2020). Janis Ikstens (2015) has also argued that the EAC is often the "second choice" committee for parliamentarians, meaning that they are less interested in EAC matters than those issues discussed in their "primary" committee. Moreover, the chair of the EAC is often from the same party as the foreign minister (as was the case from 2011-2018) or from an ideologically similar pro-European party, reducing the threat of disagreements and rejection of the government's position but perhaps weakening the EAC's role as a watchdog of EU policy (Table 1.2). The EAC's broad mandate also give committee members the opportunity to scrutinize other EU related issues in Latvia, such as spending of EU structural funds, Latvia's preparedness for different Brexit scenarios as well as progress of major EU-funded projects such as Rail Baltica. The EAC would clearly be far more effective in performing these tasks if it had the necessary human capital and analytical instruments to systematically scrutinize and provide advice on government positions and EU affairs in Latvia (Tērauda interview 2020).

The Saeima's scope of operation in EU affairs was expanded by the Lisbon Treaty which granted national parliaments new powers to get involved in the early stages of drafting legislation, ensuring that new legislative acts comply with the core EU principles of subsidiarity (that decisions must be made at the lowest possible level) and proportionality (that EU actions should be limited to just what is necessary to achieve a concrete goal). The EAC, as the Saeima's representative in EU affairs, has eight weeks to return a "reasoned opinion" that a draft legislative act does not comply with the subsidiarity principle after receiving it from the European Commission. Each of the EU's member state parliaments has two votes (bicameral legislatures have one vote for each chamber) and when the number of reasoned opinions reaches one-third of all votes, the European Commission must review the proposal and explain its decision. This is known as the "yellow card" procedure. The "orange card" procedure kicks in when a majority of member state parliament votes submit reasoned opinions under an act that falls under the ordinary legislative procedure. However, the EAC has rarely debated or drafted a reasoned opinion, largely because of the issues of time and analytical capacity (Ikstens, 2015, Tērauda interview 2020).

3 The EAC also has ex-post powers, but these are rarely used (Ikstens 2015). 
Table 1.1.2. Chairs of the European Affairs Committee (EAC). 1995-2020

\begin{tabular}{|c|c|c|}
\hline Saeima & Name of chairperson / party & Time in office \\
\hline \multirow{3}{*}{ 6. saeima $1995-1998$} & Māris Gailis (Latvijas Cel̦š) & 16.11.1995-08.02.1996 \\
\hline & Anatolijs Gorbunovs (Latvijas Cel̦š) & 08.02.1996-08.08.1996 \\
\hline & Edvīns Inkēns (Latvijas Cel̦š) & 30.09.1996-02.11.1998 \\
\hline 7. Saeima 1998-2002 & Edvīns Inkēns (Latvijas Cel̦š) & 12.11.1998-04.11.2002 \\
\hline \multirow{2}{*}{ 8. Saeima $2002-2006$} & Guntars Krasts (Tēvzemei un Brīvībai/LNNK) & 21.11.2002-21.07.2004 \\
\hline & Oskars Kastēns (Latvijas Pirmā Partija) & $12.08 .2004-06.11 .2006$ \\
\hline 9. Saeima 2006-2010 & Vaira Paegle (Tautas Partija) & $16.11 .2006-02.11 .2010$ \\
\hline 10. Saeima 2010-2011 & Imants Viesturs Liegis (Vienotība) & 04.11.2010-17.10.2011 \\
\hline 11. Saeima 2011-2014 & Zanda Kalniņa-Lukaševica (Reformu Partija) & 20.10.2011-03.11.2014 \\
\hline 12. Saeima 2014-2018 & Lolita Čigāne (Vienotība) & 06.11.2014-05.11.2018 \\
\hline 13. Saeima 2018- & Vita Anda Tērauda (Attīstībai/Par!) & 20.11.2018- \\
\hline
\end{tabular}

Source: Saeima, 2020

Membership of the EU has, however, been a catalyst for the Saeima's enhanced cooperation with other European legislatures. The oldest cooperation forum on European affairs, founded in Madrid in 1989, is the Conference of parliamentary committees for European Union affairs (COSAC), which provides a platform for national parliaments to communicate, network and engage with the European Parliament. ${ }^{4}$ Latvia is represented by six parliamentarians at the bi-annual meetings which typically take place in the country holding the six month presidency of the Council of the European Union at that time. The EAC has also forged close working relations with parallel European Committees in the Estonian and Lithuanian legislatures and they frequently hold common sessions on European issues, particularly those issues important to the Baltic region (such as Rail Baltica).

The EAC has a broad mandate but lacks the human and analytical capital to fully utilize its broad powers. The chair of the EAC has pointed out that the interests of individual deputies, rather than systematic and strategic interests of the state, drive debates in the committee. As a result, much time is given over to values issues (especially migration, democracy and minority rights) as well as research and innovation since the 2018 parliamentary election. The EAC is important as the most outwardlooking part of the Latvian parliament, regularly forging links with other parliaments, and considering EU policies, something that does not occur in any great depth elsewhere in the parliament, even in relevant sectoral committees.

\section{Head of State}

In contrast to the executive and the legislature, the post-accession years have seen a distinct rollback in the extent to which the EU impacts the office of Latvia's president. Vaira Vike Freiberga, who held the office of president for two terms between 1999 and 2007, was heavily involved in Latvia's accession to the EU. Indeed, her personal website re-publishes an article from Latvia's public media that listed accession to the EU as the number one achievement of her presidency. The president certainly played an important domestic and international role in promoting the EU between 1999 and 2004. Domestically, the president "mobilized politicians, state institutions and civil servants, to carry out all the necessary reforms" that would hasten Latvia's membership of the EU (LSM 2017). Internationally, Vīke-Freiberga used her fluent knowledge of French and English in meetings with European leaders as well as speeches pushing Latvia's European credentials. In the brief summary of her presidency on

\footnotetext{
4 The Lisbon Treaty states that COSAC "may submit any contribution it deems appropriate for the attention of the European Parliament, the Council and the Commission. The Conference shall in addition promote the exchange of information and best practice between national Parliaments and the European Parliament, including their special committees. It may also organise interparliamentary conferences on specific topics, in particular to debate matters of common foreign and security policy, including common security and defence policy. Contributions from the Conference shall not bind national Parliaments and shall not prejudge their positions." Article 10 of Protocol (No 1) on the Role of National Parliaments in the European Union of the Treaty of Lisbon.
} 
the Latvian president's website, it states that she "played a leading role in achieving Latvia's membership in NATO and the European Union" (State President 2020). None of Vikne-Freiberga's immediate three successors as president - Valdis Zatlers, Andris Bērziņš and Raimonds Vējonis - mention any dimension of European affairs among their accomplishments.

This is because Latvia's head of state has no formal role in the national or European decision-making system. While Lithuania's president, who is directly elected in a popular vote, attends meetings of the European Council, Latvia is represented by the prime minister. Indeed, the prime minister, particularly one active in European affairs and with good English language skills, such as ex-European Parliamentarian Krišjānis Kariņš, is just as visible an international representative of Latvia than the president, part of a broader process of executive power centralization known as the "presidentalization" of European politics (Poguntke \& Webb 2005). Nevertheless, a Google trends analysis of the period from 1. September 2019 to 1 . September 2020 finds that Egils Levits has been googled internationally on average 35 times a week while Krišjānis Kariņš was googled an average of 18 times a week (Google Trends 2020). Thus, Latvia's president does appear to maintain a higher international profile than the prime minister. Nevertheless, it is clear that the state president's office is the only major Latvian political institution to have been nationalized rather than europeanized over the last decade and a half.

\section{Political parties}

Political parties are the key actors in domestic democratic politics. Parties recruit individuals to stand as candidates in elections and fill public offices, conduct election campaigns, develop and enact programmes as well as coordinate the work of legislatures and executives. Latvia's political parties have clearly been impacted by membership of the EU. Party members sit in the EAC or serve as Ministers shuffling between meetings in Riga and Brussels. Some may even be MEPs or serve in the office of MEPs in Brussels and Strasbourg. Parties rally their members to campaign in European Parliament elections every five years and forge links with other similar political parties through membership of party groups in the European Parliament and europarties. This section considers the impact of the EU on two key aspects of political parties: (i) the party organization and (ii) party ideology and policy.

Relations between national parties and the European level politics are typically structured through groups in the European parliament and Europarties. The first European-level political groups formed in the Common
Assembly of the European Coal and Steel Community, the precursor to the modern European Parliament, in the 1950s. Centre-right, centre-left and liberal political groups mirrored the three main post-war political blocks in the six founding member states. Smaller, more ideologically diverse, party groups emerged as the European Economic Community, as the EU was known at that time, enlarged in the 1970s. Productive cooperation in the European Parliament, as well as the forthcoming 1979 direct elections to the European Parliament, led to the gradual formation of European political parties at the European level (known as "Europarties"). Europarties are legally distinct, but linked to, the party groups in the European Parliament and also receive their core financing from the European Parliament's budget. However, they also have as members parties that are not represented in the European Parliament. Table 1.3 details the European Parliament party group and Europarty membership of Latvia's major political parties in 2020.

Europarties are the main agents of party europeanization in Latvia and have a significant impact on party central offices in particular. The European People's Party (EPP) is the oldest and most influential europarty. Bearing in mind that the majority of parliamentary political parties in Latvia have been clustered around the centre-right, there has been quite some competition among Latvian parties to join the EPP. As of 2020, only Vienotība is a member, although both the Jauna Konservatīvā Partija and Zalı un Zemnieku Savienība have expressed an interest in joining. However, Vienotība likely uses its position as an existing EPP member to delay the membership of other Latvian parties (Ozola interview, 2020). What are the benefits of europarty membership that Vienotība is so reluctant to share?

At the European level, europarty affiliation gives direct entry to a party group in the European Parliament, which increases the possibility of gaining senior positions in committees and influential raporteur roles in guiding legislation through the legislature. For ministers and leaders it provides another network for forging alliances and attempting to influence decisions before meetings of the Council of the EU and the European Council.

At the national level, the influence of europarties is most directly felt in party central offices. The major parties typically have a board member responsible for interaction with their respective europarty and this contact can be quite intensive. Party financing laws mean that the europarties cannot give direct financial support to the Latvian parties, but the europarties fund different forms of cooperation. ${ }^{5}$ In the case of Vienotiba and EPP, for example, EPP working groups meet every two months, additionally there are political assemblies and

\footnotetext{
5 Europarties are primarily funded by annual contributions from the EU budget that can cover up to $90 \%$ of a europarty's expenditure. The sums can be quite substantial. In 2020, for example, EPP was awarded funding of 11.1 million EUR and ALDE 5.4 million EUR (European Parliament 2020).
} 
Table 1.1.3. Latvian parties and their membership of Europarties and European Parliament groups in 2020

\begin{tabular}{|c|c|c|}
\hline EP Political Group & Europarty & Latvian party member \\
\hline $\begin{array}{l}\text { Group of the European People's Party } \\
\text { (EPP) }\end{array}$ & European People's Party (EPP) & Vienotība \\
\hline $\begin{array}{l}\text { Group of the Progressive Alliance } \\
\text { of Socialists and Democrats in } \\
\text { the European Parliament (S\&D) }\end{array}$ & Party of European Socialists (PES) & Sociāldemokrātiskā Partija "Saskaṇa" \\
\hline Renew Europe Group & $\begin{array}{l}\text { Alliance of Liberals and Democrats for } \\
\text { Europe (ALDE) }\end{array}$ & $\begin{array}{l}\text { Latvijas Attīstībai } \\
\text { Kustība Par! }\end{array}$ \\
\hline $\begin{array}{l}\text { Group of the Greens / European Free } \\
\text { Alliance }\end{array}$ & $\begin{array}{l}\text { European Green Party } \\
\text { Party of the European Left }\end{array}$ & Latvijas Krievu Savienība $^{6}$ \\
\hline $\begin{array}{l}\text { European Conservatives and Reformists } \\
\text { Group }\end{array}$ & $\begin{array}{l}\text { European Conservatives and Reformists } \\
\text { Party }\end{array}$ & Nacionālā Apvienība \\
\hline No affiliation & No affiliation & $\begin{array}{l}\text { KPV LV } \\
\text { Jaunā Konservatīvā Partija } \\
\text { Latvijas Reǵionu Apvienība } \\
\text { Zaļo un Zemnieku Savienība }\end{array}$ \\
\hline
\end{tabular}

a europarty congress every two years (Ikstens interview, 2020). In addition, there is regional cooperation between, for example, EPP, ALDE and PES member parties in the Baltic states and a broader cooperation with Nordic parties (Ikstens interview 2020, Jesajana interview 2020, Sers interview 2020). For example, Academia Balta is a regional programme in the Baltic states, funded by ALDE, that annually organizes three seminars in each Baltic capital for ten members of each ALDE-affiliated Baltic party. The seminars have guest lecturers from ALDE parties speaking on various aspects of political communication and election campaigning. ALDE also organizes a European Women's Academy to develop women in politics (Jesajana 2020). Europarty membership also gives access to thinktanks such as the Konrad Adenauer (EPP) and Frierich Ebert (social democrat) foundations as well as access to data. ALDE, for example, provided A/P with a Europe-wide survey of voters, including Latvians, in the run-up to the 2019 European parliament election (Jesajana interview 2020). As well as building international links and contacts the europarties aid the modernization of the Latvian parties (Ikstens 2020, Jesajana 2020).

Europarties give Latvian parties a sense of identity, a feeling of belonging to a broader movement with common values. In the case of Latvijas Attīstība, which joined ALDE many years before it achieved national electoral success in the 2018 Latvian parliamentary election, membership in ALDE allowed party members to not just develop their campaigning and organizational skills but also keep their spirits up and providing "emotional support" while in the national political wilderness (Jesajana 2020). Vienotība board member Edgars Ikstens (2020) goes so far as to say that "there is no negative side to europarty membership". As the Jaunā Konservativā Partija is forced to wait for membership of the EPP it has reached out to the International Democrat Union (IDU), a global alliance of centre-right and conservative parties that counts the US Republican party and the UK Conservative party among its members. This certainly gives Jaunā Konservatīvā Partija a sense of identity and belonging to a broader movement but does not give the same scope of hard benefits and regular contacts of membership of europarties.

One area where the europarties have had only partial influence in Latvia is ideology and party programmes. Vienotība seems to be typical in cherry-picking elements of the EPP programme for the party programme in the 2019 European Parliament election (Ikstens 2020). However, party programmes in municipal, national and European elections are typically driven by local concerns. Europarty programmes are either not relevant to Latvian voters or in some cases there will be conflicting interests between parties, such as in the case of the level of direct payments to different European farmers. European leaders are generally not well known in Latvia and cannot be used in election campaigns (Ikstens 2020). However, this is not say that political campaigns have not been entirely europeanized. In 2019 Frans Timmermans was the face of Saskana's European Parliament campaign

\footnotetext{
6 Latvijas Krievu Savienība is a member of the Group of the Greens / European Free Alliance in the European Parliament but has not
} joined either of the Europarties connected to the group. 
and the party repeatedly stressed that its programme was built on PES' common European strategy and values. In the early Riga municipal election in 2020, A/PAR/PRO made much of the municipal success of the youthful Vilnius mayor, Remigijus Šimašius, who is from the ALDE affiliated party in Vilnius with which Latvijas Attīstībai has forged close links via ALDE.

European issues have become a point of contestation between Latvia's political parties, moving beyond European Parliament elections and into national and local politics. In 2015 battles over the EU's relocation plan for refugees seeped into the Latvian political agenda. Party positions on the EU are typically incorporated into Saeima elections. In 2018 Nacionāla Apvieniba stated that they would continue to support the EU as a nation of sovereign states and stand against federalization while AP argued that Latvia should be at the heart of Europe in a more integrated eurozone and single market (Nacionālā Apvienība 2018, Attīstība/Par 2018). However, the debates are rather limited in scope due to the lack of a serious eurosceptic party in Latvia to challenge the broad pro-EU consensus (Auers 2020). While parties debate EU policies and the scope of integration, they do not dispute Latvia's belonging to the EU.

\section{Interest groups}

Interest groups - understood as membership organizations that appeal to government but, in contrast to political parties, do not participate in elections (Wilson
1990) - have also felt the impact of europeanization, particularly those interest groups representing economic interests. Membership of the EU's single market, and the fact that some $70 \%$ of Latvia's exports go to the EU, means that decision-making on a multiplicity of economic issues affecting businesses and society more broadly takes place at both the national and supranational levels. This has led to the more influential interest groups, such as business associations like the Latvian Chamber of Commerce (LTRK) and the Latvian Employer's Confederation (LDDK) forging (i) closer relationships with similar organizations in other EU states (ii) fighting for their interests through representation in corporatist EU institutions and (iii) participation in relevant Europeanlevel interest groups. Direct lobbying through the EU pluralist lobbying system is much rarer.

Inese Stepina (interview 2020), Deputy General Director of LDDK with responsibility for EU affairs, pointed out that EU issues have merged with national issues. As a social partner at both the national and European levels, LDDK is involved in multiple national and European-level committees. At the national level alone, it issues some 300-400 opinions every year and has a formal role in approving Latvia's national negotiating positions. However, as is the case with the Latvian parliament, it is hampered by limited financial and human capital capacity, being unable to open a permanent representation in Brussels and fully participate in Brussels committees as well as the work of Business Europe of which it is Latvia's member. In contrast, LTRK, which is not an official social partner, places far greater

\section{Figure 1.1.1. Trust in political parties, Saeima and Cabinet of Ministers. 2004-2020}

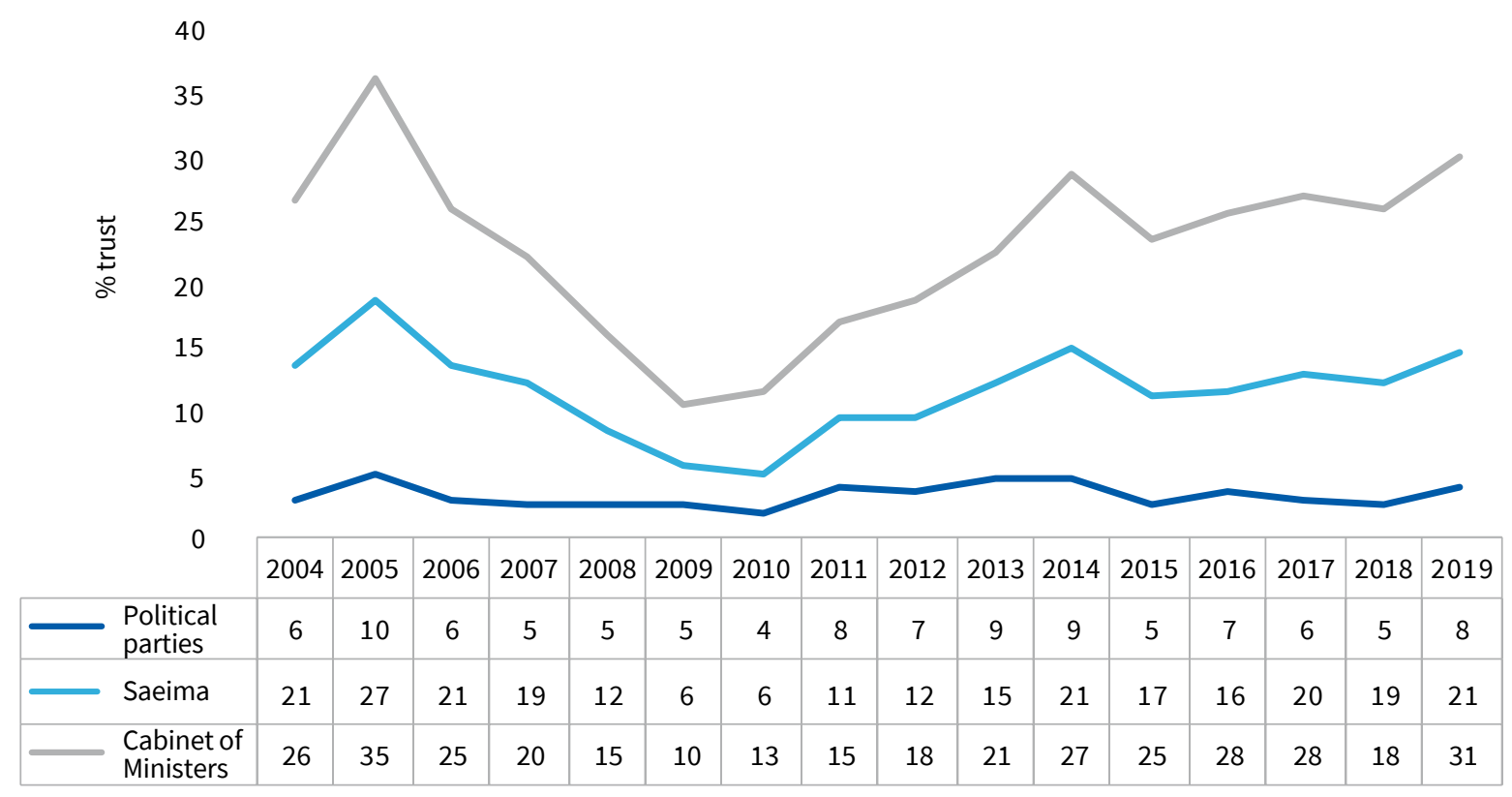

Source: European Commission 2020. 
stock in its membership of Eurochambres, which represents 20 million businesses and 120 million employees (almost half of all non-public sector employees) across Europe, as an instrument of influence. Aigars Rostovskis (interview 2020), the president of LTRK, has assumed an active role in the Eurochambres, using his position in the organization's Directors Council and as co-chair of the skills and entrepeneurship committee to stay on top of policy developments and evolving best practices in other EU states and communicate the interests of LTRK's members, via Eurochambres, to EU institutions.

Delna, the Latvian branch of the global anti-corruption organization Transparency International (TI), similarly directs most of its European lobbying efforts through TI's central office in Brussels (Gātere interview, 2020). This gives Delna access to a dedicated team of Europe-oriented experts in the TI office as well as saving money and time as it does not have to register as a lobbyist. After all, as corruption has developed a more cross-border nature, not least because of Latvia's membership of the EU, anti-corruption initiatives have also developed a more international dimension. Delna has also found that the annual European Commission reports on Latvia exert pressure on government institutions to undertake certain anti-corruption reforms. The EU has also opened up greater funding opportunities for its activities, as national budget financing for NGOs remains at around one million euros, with Delna usually being allocated an annual
12,000 EUR (Gātere 2020). Membership of the EU allows Delna to compete for project financing as well as expert consultations, typically in consortiums with other national branches of TI. This also means that Delna, whose work on anti-corruption has regularly attracted domestic criticism, now also faces criticism and scrutiny at the European level. In 2017 Ventspils mayor Aivars Lembergs sent a formal letter to the European Commission requesting further information on Delna's EU project scrutiny activities in Latvia (Ventspils 2017).

\section{Conclusion}

Kenneth Dyson and Klaus H. Goetz $(2003,386)$ have argued that membership of the EU leads to "progressively Europeanized public policies, a semi-europeanized polity, and a largely non-europeanized politics". In other words, legislation is Europeanized, the executive and legislature partially europeanized while parties and interest groups are largely untouched by europeanization. The Latvian case indicates that European integration has continued apace and now also parties and interest groups are strongly affected by Europe. However, despite the considerable impact of the EU on the political system, Figure 1.1. shows that the Latvian public's attitudes towards political institutions and actors remains largely unchanged, and untrusting, after more than a decade and a half of EU membership.

\section{Main conclusions and main tasks}

\section{Main conclusions}

Membership of the EU has clearly had a profound impact on Latvia's political system. Government ministers and civil servants shuffle between Brussels and Riga as well as other European capitals and prime ministers increasingly interact with their counterparts in other EU member states and their diaries fill-up with bilateral, regional and European Council summits of political leaders. ${ }^{7}$ The Saeima has established a major new committee - the European Affairs Committee - to help deal with the incessant flow of legislative acts, often extremely technical in nature, as well as approving national negotiating positions. Political parties compete in European Parliament elections and ever more intensively interact with ideologically similar European parties. Interest groups and non-governmental organizations have discovered a whole new world of international partnerships, funding opportunities and European-level arena's for interest representation. Arguably only the office of the state president has seen a decline in the salience of European issues since accession in 2004.

\section{Main tasks}

The current system of national position formulation places a great deal of influence and power in the Foreign Ministry which has flexibility in formulating national positions as it is not encumbered by a medium- or long-term document specifying Latvia's national interests in the EU. This system has worked quite well as Latvia has had a comparatively lower turnover of Foreign Ministers than other ministerial portfolios (including prime ministers).

\footnotetext{
7 Brussels has been the number one business travel destination for Latvian civil servants since accession to the EU, taking up the biggest share of the 4.1 million EUR budgeted for government ministry travel in 2019. Unsurprisingly, the Foreign Ministry had the biggest travel budget (880,000 EUR), followed by the Ministry for the Regions and Environment (675,000 EUR) and the Finance Ministry (421,000 EUR) (Vilcāne 2019).
} 
However, this may not be the case in the future. A medium- or long-term document identifying Latvia's interests in the EU would provide stability and predictability in cases of domestic political instability.

The Saeima's European Affairs Committee has a strong mandate but is hobbled by a lack of time and resources to provide deep scrutiny of Latvia's national positions and European legislation. Other parliamentary committees have the same challenge. The Saeima should expand the remit and capacity of the Analytical Service and provide sufficient financing to its committees, including the EAC, to ensure that they have enough resources to at least partially balance those of the executive. 


\subsection{Europeanization, soft instruments, and their consequences}

\section{Iveta Reinholde}

\section{Introduction}

Pursuant to the Lisbon Treaty of the European Union (the EU), administrative cooperation is an area in which the EU only has the right to provide support, coordinate cooperation and, if necessary, take additional action to that already taken by the Member States. To put it differently, since the establishment of the EU, administrative cooperation between the Member States and issues of the functioning of the Member States' administrative systems have been in the discretion of the Member States themselves. Moreover, although classification of administrative systems has been developed in the academic environment, the administrative system of each EU Member State is unique and reflects the dynamics of its national development. At the same time, the membership of states in the EU and actions aimed at achieving common aims have created a particular situation in which the unique administrations of the Member States are looking for ways to simplify and speed up their cooperation.

\section{The mechanism of the EU's impact on administration}

Public administration views Europeanization from two perspectives. The first sees Europeanization as a top-down approach, which means transposition and integration of EU norms, values and legal acts into the daily li fe of Member-State institutions. The other perspective, or the bottom-up approach, envisages that institutional structures form on the Member-State and regional level, later changing the nature and style of activities on the EU level (Borzel, 2005).

The EU impacts public administration directly by using such legal acts as directives, regulations and rulings by the Court of Justice of the European Union whereas the range of instruments of indirect impact is broader, more diverse and with consequences more difficult to detect. Indirect instruments influence the way and form in which public administration operates. However, the EU does not have formal requirements and provisions which the public administrations of the Member States should comply with. At the same time, Member States' wish to collaborate with the administration of other Member States entails many challenges, which lead directly to Europeanization of administration.

To simplify cooperation between the Member States' administrations on the level of standard operational procedures, institutions adjust and develop a unified style of operation. This adjustment may apply to the structure of public administration (for example, by establishing similar institutions in the Member States) and the structure of institutions (for example, by establishing ministerial departments with similar functions or subordinated institutions with similar objectives), thus ensuring swifter cooperation between the Member States themselves as well as between the Member States and the respective Directorate General of the EU. For instance, cooperation of this kind developed for implementation of the EU education programme when national agencies for coordination of the programme were established in the Member States, similarly to development of the State Education Development Agency. This is the most common model of Europeanization. However, situations occur where the national administration itself puts pressure on its government to ensure the compatibility of its operations or structure with the operational principles of EU administration or at least with the dominant understanding of it. Truth be told, this pressure most often pertains to "the comfort and wellbeing of bureaucrats" most often these are issues related to remuneration for work and working conditions. Most frequently this pressure can be seen in various informative materials, in which representatives of the bureaucracy are trying to give a public message that, in other countries, the remuneration of civil servants is higher and their social guarantees more generous.

In their cooperation, the public administrations of the Member States take over the values of European administrative space and other soft instruments of administration, such as best practice and policy transfer. In the process of Europeanization, the Member States encounter "the effect of demonstration", when local practice in terms of work, approach or idea suddenly becomes known within EU space and is recognised as being the best practice. Once identified as "best practice", this in turn becomes an object of policy transfer, recommended to the other Member States for implementation. The best practice-related demonstration effect most often arises in places with differences between the local administrations and the EU. Following accession 


\section{Figure 1.2.1. Number of civil servants in Latvia (2004-2019)}

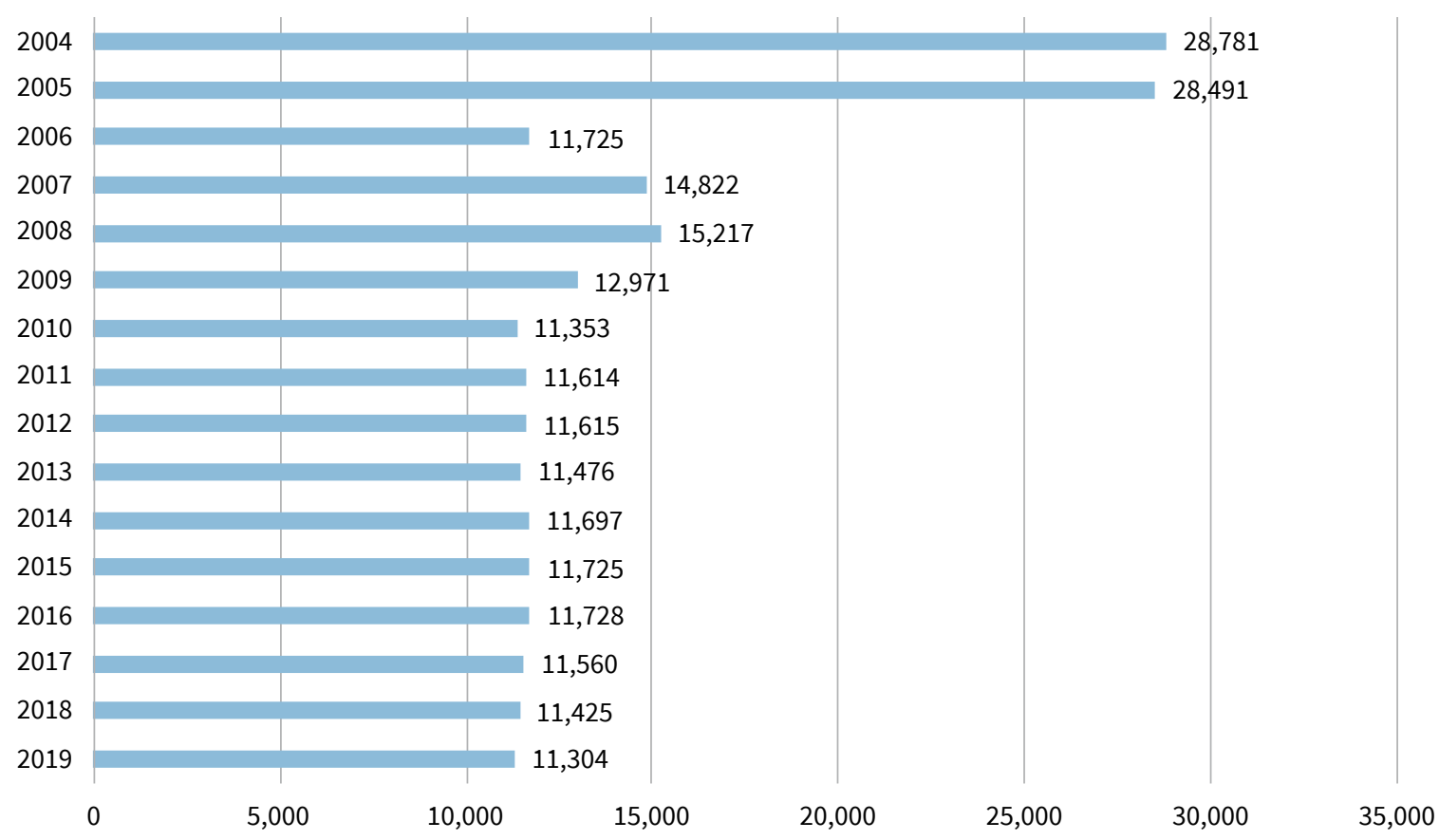

Source: Ministry of Finance, 2017; State Chancellery, 2018; State Chancellery, 2019.

Figure 1.2.2. Number of employees in public administration compared with the total number of persons employed by the state as a whole (2019)

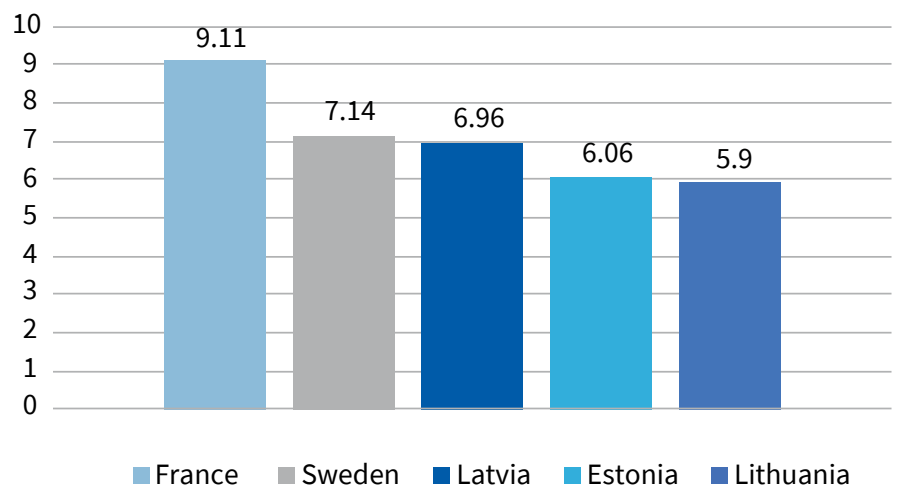

Source: State Chancellery, 2019.

to the EU, Latvia learned how to implement projects financed by structural funds, looking at the best practice of other Member States, and, for this purpose, implementing bodies (for example the Central Finance and Contracting Agency (CFLA, 2019)) regularly organise experience-seminars. In a similar vein, reform of the curriculum for Latvian vocational education used the best practice from Western Europe.

Finally, the "needlessness effect" assumes that the European Union's frequency and ubiquity may mean that the national administrations will no longer be needed in the future.

Since Latvia's accession to the EU, the number of civil servants has decreased. However, these data should be viewed critically since the EU did not create the expected "needlessness effect". Quite the contrary, in 2005 the number of civil servants decreased not because they were dismissed but because the institutions changed their status from a civil service institution to a public administration institution, thus ensuring a more flexible 
approach to issues of remuneration and the ability to offer more competitive remuneration to their employees. Thus the number of civil servants at around 11,000 is the actual number of civil servants in public administration, comprising positions that are important for national development. Data from the State Chancellery (2019) show that, in 2019, 60,251 persons were employed in institutions funded from the state budget, including these 11,304 civil servants.

Examination of the number of employees in public administration compared with the number of employees in the labour market shows that the public administration in the new EU Member States is smaller compared to the old Member States. However, awareness is needed that the "needlessness effect" is rather myth than reality. In some areas - agriculture, competition, environmental policy, regional policy - where the EU intervenes to a large extent, the administration and interests of the Member States are of great importance. However, the process of cooperation causes segmentation, where in some areas cooperation between the Member States and the EU is much more intensive than in others. In the areas of agriculture and environment policy, a much more intensive and dynamic flow of information can be observed between the EU's administration and the Member States than in social policy and medicine. Segmentation or greater dynamics of cooperation in one area causes the need to coordinate and structure the intensive flow of information to ensure sharing of information within each Member State with other institutions and NGOs and also to ensure that all players inside each Member State adopt a similar style of operations. This leads to professionalisation and bureaucratisation of NGOs in the segmented areas. Thus permanent and ad hoc working groups and commissions may be established to coordinate issues in order to reach agreement between various players.

However, the issue of internal coordination is relevant in the context of whether this helps to identify and reinforce the national interests that will be represented on the EU level. Finally, segmentation and increased coordination results in a "multiplicative effect", which determines that closer contacts and more intensive cooperation with the EU's administration and organisations must also be aligned with local organisations as well as the administrative and political leadership. In this way, the effect of Europeanization is felt by seemingly unconnected organisations, for example companies processing agricultural products and even consumers.

\section{European administrative space and administrative convergence}

The EU has no acquis norms that would regulate the operation of public administration; however, over time, a shared understanding has evolved in the EU of how public administration should function and make decisions. This shared understanding comprises generally defined principles that are taken into account in all EU Member States and are accordingly implemented in the public administrations of the Member States, irrespective of the Member State's administrative model. So sometimes the denomination "European Administrative Space" (EAS) is used in discussing the public administrations of the EU Member States. The boundaries of EAS coincide with the EU's borders, that is, EAS exists within the same boundaries as the EU, which in turn assumes that, within that physical space, unified principles of administrative cooperation exist that allow the Member States to cooperate and to understand each other. The concept of EAS is based both on a uniform understanding of European economic and social space but also as a space where legal collaboration for the implementation of EU law occurs.

Moreover, the principles of EAS have developed together with the EU itself, so they reflect European traditions and administrative values. In the context of multi-level governance, EAS reflects those common administrative values that are inherent on all levels of governance in the EU. Thanks to those values, cooperation between levels is possible and the process of Europeanization occurs. The most important principles of EAS are certainty, reliability, predictability, accountability, transparency, openness, efficiency, effectiveness, technical and managerial competence, capacity of organisations, and popular involvement (Nizzo, 1999, 8-9).

In the context of EAS, certainty should be viewed from the perspective of administrative law, where the work of administration should be legally certain, predictable, and foreseeable. Administration is based on the rule of law, which marks the legal aspect of its operations. Predictability of administration also means proportionality when deciding on administrative action, which involves examining to what extent a person's rights will be restricted and what the general benefit gained by society will be (Briede, 2000). Additionally, administrative action which is based on a foreseeable and established procedure ensures precise and unbiased application of legal norms, objectivity, and respect for human dignity (SIGMA, 1999, 10). Openness, together with transparency, not only allows avoiding corruption and poor functioning of administration but also facilitates societal involvement in the adoption of administrative decisions. Thus society is involved not only in governance by electing the parliament, which makes political decisions in the name of society, but also in institutional supervision of the work of public administration via the court and the ombudsman. Accountability should be linked to the administration's responsibility towards both the law and society. Moreover, any individual who submits a claim to the court subjects the administration's actions for judicial review. This creates a substantial counterweight to the administrative power. Supervision of administration ensures that institutions exercise the power granted to them within 
Figure 1.2.3. European administrative values

\begin{tabular}{|c|c|c|c|}
\hline \multicolumn{2}{|c|}{ RULE OF LAW } & \multicolumn{2}{|c|}{$\begin{array}{l}\text { Corruption prevention } \\
\text { OPENNESS }\end{array}$} \\
\hline Certainty & Objectivity & Transparency & Participation \\
\hline Compliance & & \multicolumn{2}{|l|}{ Economy } \\
\hline
\end{tabular}

ACCOUNTABILITY

Monitoring

\section{EFFICIENCY}

Effectiviness

Source: Cordona, 2009.

the framework of the law and for defined aims. This, in turn, is of relevance in ensuring both public and private interests. Finally, effectiveness is deemed to be a value of the administration only when the administration performs its work within the framework of the resources available to it and, at the same time, ensures that aims are achieved.

Integration of Latvia's public administration into EAS has influenced public opinion. It was established in 2020 that $33.9 \%$ consider the public administration as being professional and open and that almost the same proportion of respondents - $41.4 \%$ - had a negative assessment of the public administration (HDR Survey 2020). Moreover, $62 \%$ of respondents adhere to the view that bureaucracy has increased in Latvia (HDR Survey, 2020). While the EU cannot be blamed for all disasters, nevertheless the large number of persons who considered that all matters are decided in Brussels suggests that the EU's impact on public administration is an undeniable fact, although the scope of impact can differ in different areas. In September 1999, SKDS conducted a study on the attitude of people in Latvia towards public administration and the national civil service, as well as people's assessment of the functioning of state institutions. The responses received in this study reveal a peculiar trend $-33.4 \%$ of respondents evaluate public administration rather positively compared with $36.3 \%$ who take a negative view, whereas review of the data only on the negative and positive scale reveals that almost $44.5 \%$ of respondents assess the work of public institutions negatively and only $36.9 \%$ positively, while for $18.6 \%$ of respondents it was difficult to define their assessment (SKDS, 1999, 19). Although two decades have passed, people's assessment of public administration has not changed significantly, which suggests that dissatisfaction with bureaucracy exists irrespective of the benefits, requirements and values provided by the EU. In turn, a study of people's satisfaction with the work of ministries in 2001 showed that the work of the Ministry of Culture had the most positive assessment, but the worst - the work of the Special Task Minister in Matters of Public Reforms. To illustrate, satisfaction with the Ministry of Culture vacillated within a range between $59.1 \%$ to $66.9 \%$ but satisfaction with the Special Task Minister in Matters of Public Reforms - from $15.1 \%$ to $19.6 \%$ (SKDS, 2001).

\section{Europeanization of policies}

Since publication of the white paper "European Governance" in 2001, the European Commission has declared its aim, namely implementation of effective and timely policies on the relevant level of governance (European Commission, 2001, 14). However, in declaring the principle of coherence, the European Commission acknowledges that coherence is needed both with respect to policies and the institutions that implement those policies. Moreover, the principle of coherence clearly indicates that the involvement of regional and local self-governments in the development of EU policies should be increased.

In the process of Europeanization of policies, the Member States (including Latvia) are not merely passive enforcers of the EU's requirements. The Member States can actively influence European policies, institutions and processes that they will later have to adjust to their administrative system. Thus national governments turn into implementers and changers of EU policies because, on the national level, institutions, entrepreneurs and non-governmental organisations force the government to influence EU policy so as to comply with EU interests but, at the same time, would also take into consideration national interests. 


\section{Consequences of Europeanization}

"Water supply system projects worth millions, where implementation in Latvia is covered by European money and in compliance with European Union directives have, one might say, suffered a fiasco vis-à-vis the lifestyle practised by Latvians. Five million lats have been invested in a water supply and sewage project in Skrīveri region. A major part of these are European resources; however, 400 thousand are from local government money. [..] Out of a planned 1200 persons, only 860 use the new system. The Ministry of Environmental Protection and Regional Development (MEPRD), having collected the data, has found that in places where previously there had been no water or sewage pipes now only $20 \%$ of the residents of private homes are connected to them. In this area, tension is also caused by the fact that quite soon - the end of 2015 - the term expires when Latvia had promised the European Commission to ensure qualitative water and sewage treatment in populated areas with the number of inhabitants above 2000, which includes Skriveri. Otherwise the risk is of sanctions being applied to the State of Latvia."

Source: Diena (2013). Privātmāju īpašnieki nesteidz pieslēgties maǵistrālajiem ūdensvadiem. Available:

https://www.diena.lv/raksts/latvija/zinas/privatmaju-ipasnieki-nesteidz-pieslegties-magistralajiem-udensvadiem-14007376

In contrast, on the EU level national governments try to change and impact EU policy to make it comply with the pressure of domestic policy or at least to decrease its unforeseen consequences. This two-level game ensures a systemic relationship between local and European policy, where national governments are intermediaries and local actors are predominantly beneficiaries. Quite often, in a situation where national bureaucrats and social actors, who are not involved in the process of decision-making, are unwilling to assume the difficulties of implementation, "the issue of compliance" (also called the paradox of overzealousness) occurs. Social actors try to blame the government for future costs that will arise if the government does not ensure that EU provisions are implemented so that penal sanctions are imposed upon the state.

Thus, the various impacts of Europeanization can be explained as a situation of "the best possible compatibility" between the EU and national policies, institutions, and processes. However, the opinion that many EU norms remain to be implemented prevails in Latvian society, with $48.2 \%$ believing this (HDR Survey, 2020). Regrettably, only about one-fifth (19\%) hold the opposite opinion regarding the amount of EU regulatory norms (regulations and directives) as being proportional. Moreover, both rural and urban dwellers share a similar opinion - with $45.3 \%$ of the inhabitants of Riga, $47.4 \%$ of the inhabitants of Vidzeme and $52.2 \%$ of the inhabitants of Latgale tending to believe that Brussels' norms are too numerous (HDR Survey, 2020). On average, the EU issues some 80 regulations and 1200 directives annually, and about one-third of these regulations and directives apply to agriculture and fisheries. Indeed, since the establishment of the EU's predecessor (The European Economic Community) in 1957 , over 100,000 regulatory acts have been approved (Toshkov, s. n.).
However, it is essential to understand that a good and effective strategy is to maximise benefits and minimise policy costs in the Europeanization process. Experts recommend the Member States to "feed" their policies into the EU level and, when they have become EU policies, then to "adjust" accordingly to their own administrative reality. Put differently, the more compatible an EU policy is with the national context, the lower the costs of adjustment and administrative and legal implementation. This "feeding-in-adjustment" model may turn out to be advantageous for states with high administrative standards, whereas for a state with lower standards this may turn out to be an additional burden with additional costs.

Member States with high socioeconomic regulation try to impose their regulation throughout the EU, thus obtaining advantageous competition conditions for their national sectors and avoiding dumping by less regulated states. For instance, health, security, social and environmental regulations cause a significant increase in production costs and may cause losses when competing with states that are able to produce the same products more cheaply. Thus a peculiar opposition forms the Member States with higher standards take a stand against the Member States with lower standards, which in turn are interested in objecting to harmonisation of any standards that would cause additional costs. Less regulated states often lack regulatory administrative structures and technologies; they have to purchase technologies and invest in people. Nor can the more highly-regulated states give in since, for these states, lowering the requirements of standards also means additional costs. Moreover, in the process of Europeanization of policies, not only the wishes and choices of the Member States differ but also their capacity, too. For instance, in environmental policy, Scandinavian states have higher 
requirements than in Europe on average, whereas the states of Southern Europe most often have neither carefully developed environmental policy nor capacity. Thus a paradox occurs: the Member States with limited capacity for adopting a policy have a greater burden compared to the other Member States. The situation is similar in Latvia, which tries to adjust to Scandinavianlevel requirements in the environmental area but needs additional resources to ensure waste collection and separation.

A Member State's capacity and possibilities for gaining maximum benefit from EU policies are determined by its institutional weight and political authority on the EU level as well as on the political and administrative mechanism via which the Member States coordinate and formulate their national interests. At the same time, the factors of failure can also be outlined, due to which maximum benefit is not gained. Firstly, if a Member State's policy development competences are divided among diverse policy and administrative sectors and a lack of horizontal and vertical coordination and deficiencies arises, this leads to miscommunication among institutions and actors. Secondly, if the level of socio-economic development in a state causes high costs in applying the EU acquis then domestic policy actors might not have the incentive to implement this policy because it would be almost impossible to substantiate the costs. Finally, if differences in administrative culture exist, society or a part of it might not be ready to comply with the policy provision.

Another interesting phenomenon can be observed in the process of policy Europeanization. EU requirements may also be used to substantiate and resolve problems that a Member State is unable to resolve because of strong domestic national opposition. In cases like these, politicians and bureaucrats of the nation states assume the position that the proposed policy is EU requirements, thus imposing on other domestic players an agreement, reached on the European level, which otherwise would be dismissed by locals. For instance, the closure of Latvia's sugar refineries was publicly presented as destruction of the sugar sector imposed by the EU, although the decision to close the factories and the ensuing halting of production was taken by the owners of the sugar refineries - the shareholders. Pursuant to the plan for restructuring the sugar sector, the EU had envisaged that the producing companies would receive a fee for each sugar quota but companies which decided to stop production would receive financial support for each declined ton of the quota (Fridrihsone, 2010). Usually, a situation like this is presented as having only two possible alternatives - to accept or not to accept the EU rules of the game. Hence, the view "Brussels is making us do it" or "this has been decided in Brussels" actually reflects the limited capability of one state to impact European-level agreements and the outcome of the negotiation process. At the same time, politicians and bureaucrats are not ready to admit that they have not exhausted all possibilities to protect national interests. However, research data show that $39.9 \%$ of Latvian respondents genuinely believe that all matters are decided in Brussels and almost the same proportion of inhabitants (37.9\%) are convinced that Brussels has limited possibilities to influence the Member States in all matters (HDR Survey, 2020).

At the same time, researchers recognise that since policies that are only national no longer exist, a multilevel mix of types of governance exists within the EU (Marks et al., 2001, 15). A trend has become outlined in practice that the first type of governance with exclusive authorisations and competences can be observed on the supranational and national level, whereas the other type, with overlapping competences, is encountered on the level of regional and local governance, where local governments cooperate with residents, public organisations and interest groups in resolving local-scale problems.

In 2005, Artis Pabriks, the Minister for Foreign Affairs at the time, said: "Talk about the European bureaucracy is not merely political folklore - the complicated structure of the EU, sometimes unclear allocation of responsibility between various administrative and political decision-making levels and institutions, has thus far actually hindered the EU's development." (Pabriks, 2005) In a 2020 study, it was established that, in general, people in Latvia are more interested (59.3\%) than not interested $(29.9 \%)$ in the impact of EU decisions (HDR Survey, 2020). At the same time $36.3 \%$ of respondents were interested in the way EU authorities and institutions operated. This means that a sufficiently large mass of Latvia's population is trying to understand both the work of EU institutions and the consequences of the EU's impact.

Already since the 1990s, the EU has been using "the open method of coordination" (OMC), which is applied in such areas as employment and economic policy, social policy as well as education and research. The OMC is one of the tools of governance based upon voluntary cooperation between the Member States. The method is founded on such policy instruments as guidelines and indicators, comparative assessment, and use of best practice. This means that no official sanctions are imposed against Member States that do not submit indicators. The effectiveness of the method derives from the following conditions: if all Member States have agreed on the purpose and a Member State nevertheless breaches the agreement or performs poorly, moral pressure and shaming will follow.

The OMC operates in successive stages. Initially, the Council of the European Union agrees on broad policy aims. The aims are combined with a timeframe and concrete long-term and short-term objectives to ensure a uniform approach throughout the EU. During the second stage, policy aims are included in the Member States' national guidelines, programmes and plans, taking into account the country's specific features. The Member States can choose the instrument 
of implementation. Later, in the third stage of OMC, the Member States agree on concrete indicators for evaluating best practice and achieving objectives, on the basis of current experience and needs of the Member States. The policy is implemented in the fourth stage, during which meeting the indicators is monitored and assessed. It should be noted that the OMC is a soft instrument of governance; hence, implementation may differ among the Member States; however, the indicators are an indirect mechanism of sanctions.

Experience so far has shown that the OMC has enabled Latvia to study and adopt the valuable experience of other states, thus fostering modernisation of sectoral policies. The OMC has been used more often in the social and cultural spheres. For instance, in 2015 the EU Member States agreed, in the framework of the OMC, to develop cultural competencies in education, which happened in compliance with the action plan of the EU Council and with the aim of creating a handbook on promoting the competence of understanding culture and expressions of culture in education in Europe (LNKC, 2015). In the period from 2007 to 2014, the OMC was used to implement the EU "Youth in Action" programme, encouraging young people from various EU states to both cooperate and adopt the experience of other countries (Jaunatnes starptautisko programmu agentūra, s. n.).

\section{National positions and their development. Management of EU affairs}

In Latvia, national positions are documents that reflect the aims of Latvia that must be defended in the EU. A procedure has been introduced in Latvia for development of national positions, describing in detail the procedure for preparing Latvia's position (Cabinet of Ministers, 2009a). Put differently, the national position is the official opinion of the state of Latvia on EU policy documents, draft legal acts, issues on the agendas of meetings of committees and working groups of the EU Council.

To coordinate cooperation between institutions of public administration and other institutions in EU matters, the Senior Officials' Meeting has been set up. Pursuant to the regulation (Cabinet of Ministers, 2009b), the Meeting examines Latvia's potential priorities relating to membership in the EU and proposals pertaining to Latvia's EU membership. Additionally, the Meeting examines national positions on EU matters and other important issues related to Latvia's fully-fledged participation in the EU. To ensure its operations, the Meeting is convened at least once a month.

In accordance with the procedure introduced in Latvia, once every six months the Senior Officials' Meeting determines the institutions that are responsible for the working groups and committees of the European Commission and the Council and whose duties include developing national positions and aligning these with the co-responsible ministries, organisations of local governments and social partners, associations and foundations. That is, the responsible institutions perform all tasks needed to prepare positions that express Latvia's interests and would ensure protection of national interests on the EU level. The responsible institution is also the one to inform society and the social partners about EU policy documents and draft legal acts as well as Latvia's interests in them to ensure society's involvement in EU decision-making. In the process of developing national positions, the Ministry of Foreign Affairs has more duties and greater responsibility compared to line Ministries because the Ministry of Foreign Affairs may be both responsible for an issue relating to foreign affairs and, additionally, for coordinating development of all national positions and supervising these to ensure that national policies are unified from the vantage point of diverse policies. This means that, with respect to inter-sectoral matters, national positions must represent the concerted opinion of the sectors involved.

As regards procedure, national positions are developed at as early a stage of discussions as possible, as soon as discussions have been commenced on the EU level, but the Senior Officials' Meeting decides whether a national position is or is not necessary. Moreover, if national interests are seriously affected on the EU level then usually an interinstitutional working group is set up, consisting of representatives from the ministries, local

\section{Box 1.2.2.}

\section{Agenda of the Senior Officials' Meeting convened on 20 May 2020}

(Meeting of senior officials 2020)

1. COVID-19 related EU initiatives, guidelines and other relevant issues.

2. Councils in May and June.

3. Issues concerning the Arctic.

4. On improvements to the procedure of EU coordination.

5. Any other business. 
governments, NGOs, and social partners. Developed national positions are approved by the government or, in urgent cases, the responsible minister. Albeit the Saeima's participation in this process is rather limited, the Saeima is informed about current issues but Latvia's national positions on issues to be examined at meetings of the Council of the European Commission are submitted for review to the European Affairs Committee of the Saeima.

\section{Impact on local governments}

At present, both the EU administration and local governments in the Member States are connected in a unified system, and they communicate and cooperate among themselves. The multi-level administration in the EU was developed as part of structural policy reform at the end of the 1980s. With Greece, Portugal and Spain acceding to the EU, discussions evolved regarding the kind of assistance that should be offered to these states so that they would reach the average EU economic level more quickly. The European Commission offered to administer structural funds, using the model created by national, regional and local level institutions of these states, in which the European Commission would participate as a supra-national actor (Hix 2005, 220). At the time, the partnership model for solving problems in administering structural funds opened up co-working possibilities for several levels of administration. Although governments and bureaucrats are the most important players in the Europeanization process, other levels of administration are also significant in the system of multilevel administration.

Thus governments have the most privileged role because they set the agenda and also control the relations between their own Member State and the EU; likewise, they have at their disposal instruments for resolving supranational problems. However, since institutional fragmentation exists in the EU as well as many actors, level procedures and considerable sectoral influence, national governments must make greater efforts to ensure representation of national interests and information flows. Moreover, the administrative apparatus of the executive power is part of the unified EU system for implementing policies due to the increasing scope of the acquis. Parliaments do not have a direct impact vis-à-vis processes of drafting EU laws; however, the parliaments try to compensate for their partial loss of authorisation by the structures set up for controlling the government: European Affairs Committees.

Partnership on the level of the European Commission and the regional level of the Member States has allowed the regions to avoid the national level in using EU financing and also enabled institutionalisation of regional representation by establishing the Committee of the Regions. Albeit participation and the role of local governments within the EU is slightly limited, their role in the Committee of the Regions is advisory. However, the actual impact of local governments depends on the structure of the state, even though the state is no longer the supreme power within the respective borders. Latvian local governments are represented on the European Committee of the Regions by seven politicians, elected by local governments, who have prepared political opinions on undeclared employment, macro-regional strategies and establishing a unified zone of value added tax in the EU (LPS, 2020).

The common trend of Europeanization shows that the importance of regional and local level authorities in the process of decision-making in the $\mathrm{EU}$ is on the increase, although traditionally the EU is regarded as a playing field for two players - at supranational and national levels. This increase in the role of the regional and local levels suggests that, in the future, due to the consequences of Europeanization, reciprocal adjustment among the Member States' authorities will reach the level on which the issue of creating a unified administrative system in the EU might be advanced in public debates (Knodt, 2004, 701). The EU Committee of the Regions notes that the EU, at the moment of its establishment, had been afflicted by "federal blindness" because it ignored the regional and the local levels but the principle of partnership, established by the EC, with long-reaching consequences, to a certain extent has cured Europe (Committee of the Regions, 2005, 8). Currently, the situation has changed because the EU multi-annual budget for 2021-2027 envisages serious financing for the most disadvantaged regions to promote exactly the regions to cooperate in drafting an aligned innovations programme, focusing on smart specialisation. Latvia also has taken a step in this direction by launching a reform to create economically stronger local governments that would be more attractive for investment (Cabinet of Ministers, 2019c). However, in public discussion immediately after shifting the administrative boundaries, issues that are topical in other EU states will need to be resolved - the prospects of regional development and cooperation, urban administration and the manifestations and consequences of urbanisation as well as the development of regional clusters in Latvia. This shows that although Europeanization has an indirect impact upon the level of local and regional administration, activities within the EU encourage Latvian local governments to look for the best solution in providing services. 


\section{Major achievements and most important tasks}

\section{Major achievements}

Under the influence of Europeanization, modernization of Latvian public administration has occurred, both by adopting European administrative values and by integrating into the process of democratic administration. The functioning of public administration in compliance with the provisions adopted in the EU has directly promoted the growth of public administration, adoption of the most recent methods and other best practices of EU states. Hence, in the process of Europeanization, a significant change of administrative values has taken place to consolidate the democratic state order.

\section{Most important tasks}

Although in terms of amount the acquis adopted annually by the EU is comparatively large, resources should be invested in Latvian public administration for more sizeable assessment of the consequences and impact of regulatory enactments. In 2018, the OECD recommended that Latvia should differentiate between regulatory enactments whose effects are assessed and those whose effects are not assessed (OECD, 2018, 210). Currently, Latvia is coping successfully with ex-ante assessment or preliminary assessment of regulatory enactments; however, ex-post assessment could significantly improve the quality of policy, eliminate deficiencies in implementation and would allow Latvia to make fuller use of possibilities to defend its interests in the process of developing the acquis, based on implementation experience.

Undoubtedly, the most important task is to explain the application of EU regulatory enactments in Latvia in the context of Latvia's national interests. This would allow the people of Latvia to understand which norms have originated under the EU's impact and which have been developed nationally. Although the multi-level system of administration is a complicated mechanism, the Latvian government should continue domestic policy discussion on what national interests are and how best to defend these on the EU level. 


\subsection{Europeanization of Latvia's foreign policy}

\section{Toms Rostoks}

What kind of impact has accession to the EU had on Latvia's foreign policy? Since membership of the EU has fundamentally changed Latvians' daily life as well as the structure and working patterns of public administration, it is likely that Europeanization has also had an impact on Latvia's foreign policy. This chapter examines three dimensions of Europeanization in Latvia's foreign and security policy: relations with Russia; the EU's Common Security and Defence Policy (CSDP); and development cooperation policy. The main focus is on the impact of Europeanization on foreign policy, although the chapter also considers Europeanization of key foreign policy-making institutions as well as domestic public opinion of major foreign policy issues.

The first section provides an overview of literature dedicated to Europeanization of foreign policy, highlighting, in particular, practical manifestations of Europeanization in Latvia's foreign policy. The second section examines the impact of Europeanization on relations between Latvia and Russia. The third section views Latvia's involvement in CSDP from the vantage point of Europeanization, while the fourth section analyses Latvia's development cooperation policy from this perspective. Although the main focus is placed on the impact on Latvia's foreign policy of integration within the EU, Latvia's attempts to influence EU foreign policy are also examined. The chapter is based on both academic literature and interviews with representatives of the Ministry of Foreign Affairs and the Ministry of Defence.

\section{Europeanization and foreign policy: globally and in Latvia}

The notion of Europeanization helps to conceptualise the relations between nation states and the supranational EU institutions. Heated discussions have evolved in the academic literature regarding the content and usefulness of this concept (e.g., Olsen, 2002); however, the most significant assumption of Europeanization is that integration with the EU changes those states which are involved in the integration process. Simultaneously, states attempt to change the EU in line with their own interests, so it can be assumed that gradual approximation of the different interests of all the actors involved occurs. Europeanization can be discussed in the categories of more and less, in that in one area of integration
Europeanization may be more or less pronounced compared to another area. Likewise, the degree of Europeanization may differ among the EU Member States.

The prevailing opinion in the academic literature is that Europeanization in foreign policy is less pronounced compared to domestic policy; however, a series of studies confirms that Europeanization also occurs in foreign policy (Major, 2005; Baun, Marek, 2013; Chrystou, Kyris, 2017; Michalski, 2013; Pomorska, 2007; Vanhoonacker, Pomorska 2013; Smith, 2017; Vilson, 2015; Aggestam, Bicchi 2019), albeit the foreign policies of all the Member States might not be Europeanized to the same extent. The same applies to diverse foreign policy aspects. External trade relations and development cooperation policy could be counted as the most Europeanized aspects of foreign policy, whereas those foreign policy aspects which are linked to relations with strategic partners and special relations with states outside the EU could be less Europeanized. In characterising Europeanization of the foreign policy of EU states, Christopher Hill and Reuben Wong write that the most Europeanised foreign policy could be that of the Benelux states and that, in turn, several states have a less Europeanized foreign policy, for instance, the Visegrad countries, Cyprus, Malta, Austria, Ireland, and Portugal (Hill, Wong 2011). Europeanization processes have been studied in Latvia as well (Ozolina, Tisenkopfs, 2005; Pastore, 2015; Ozoliņa, 2008b; Ozoliņa, 2012).

Accession to the EU has also influenced Latvia's foreign policy; however, Europeanization is rather intuited than accurately identifiable and measurable. Hypothetically, it can be assumed that, content-wise, Latvia's foreign policy would be different if Latvia had not become an EU Member State. Relations with the EU Member States and institutions would be formed from the outside, so that no consultations or approximation of interests with the other Member States in the common decision-making process would occur. Latvia could not propose its representative for the European Commission and elections for the European Parliament would not take place, so that political parties would be less Europeanized. On the governmental level, contacts with the leaders of other states and governments, as well as ministers for foreign affairs, would be less intensive. Representatives of institutions of public administration would not travel to Brussels for regular meetings, and career opportunities in EU institutions would not be open to employees of the institutions of 
public administration. There would be less of an EU presence in the activities of Latvia's local governments and non-governmental organisations. If Latvia had not acceded to the EU it would be of less interest for various third countries such as Japan, China and countries of the Central Asia region because Latvia would have no impact on the adoption of EU collective decisions, which are essential for third countries. Simultaneously, Latvia would most probably be subjected to more forceful interest from Russia. However, Latvia's membership in the EU since 2004 means that, to a certain extent, Europeanization has affected the content of Latvia's foreign policy as well as its institutions and society.

As indicated by some aspects of Latvia's foreign policy examined in the continuation of this section, Latvia had not only to define its position with respect to each of them but also to reckon with existing EU foreign policy initiatives and the positions taken by other states. Membership in the EU has reinforced Latvia's ties with all Member States; however, the impact has been particularly strong on relations with the other Baltic States and the Nordic countries, with which Latvia is often united by common interests (Ozolina, Šteinbuka, 2019). At present, the Baltic and the Nordic States can be characterised as a strong group of states with, to a certain extent, a common identity (Jēgermanis, 2020). Integration with the EU has created a strong instinct to consult with the other Member States before expressing the national foreign policy position. Often this has caused incomprehension in society. For instance, in Belarus, neighbouring Latvia, extensive protests took place following the presidential elections of 2010 and 2020; these were violently suppressed. Although officials condemned the Belarusian regime's attacks on protesters and falsification of election results, it was nevertheless obvious that Latvia would want to have a common position with the EU Member States (or at least a common position among the Baltic States, the Nordic countries and other like-minded states) because it would carry greater political weight rather than pre-emptively expressing its national position.

Accession to the EU has caused substantive changes in foreign policy; put differently, participation in the common decision-making process requires formulating the national position on the most diverse issues. This in turn has created the need to develop new substantive and regional competencies, for example in matters of development cooperation and with respect to processes in the Middle East, which prior to 2004 could not be deemed to be foreign policy priorities (except, of course, the US-led military operation in Iraq and in the context of Afghanistan). Membership in the EU has also influenced the institutional foundations of Latvia's foreign policy. Currently, the primary diplomatic efforts of the Ministry of Foreign Affairs are linked to representation of Latvia's interests in the EU, which is clearly evidenced by the number of staff at Latvia's Permanent Representation to the EU as compared to embassies.
Information provided by the Ministry of Foreign Affairs shows that 34 staff of the Foreign Ministry are currently working at Latvia's Permanent Representation to the EU (including five contract employees), whereas information available on the homepage of the Ministry of Foreign Affairs shows that the number of employees at embassies in countries that are quite important for Latvia is significantly lower. Seventeen persons work at Latvia's Embassy in Russia, three in Japan, fifteen in the USA, ten in the United Kingdom, thirteen in Germany, six in France, seven in China, and eight in India. At the same time, it must be noted that a 2019 study regarding the number of employees of eighteen EU Member States at their Permanent Representations to the EU ranks Latvia last, with 69 employees, falling behind Estonia (79) and Lithuania (94) (Sorensen, 2019).

Although in terms of staff numbers Latvia falls behind other small EU Member States, the number of staff working at Latvia's Permanent Representation to the EU has significantly increased since 2004 when only nineteen Ministry of Foreign Affairs staffers worked at Latvia's Permanent Representation to the EU (including five contract employees). With Latvia's Presidency of the Council of the EU approaching, from 2013 the number of employees at Latvia's Permanent Representation to the EU started to increase and in 2015 some 95 persons were already working at the Representation (60 permanent staff and 34 contract employees, specialised attachés not included). However, in 2016 the number of staff decreased significantly compared to the previous year, leaving 24 full-time employees and four contract employees at Latvia's Permanent Representation to the EU.

It must be underscored that the Europeanization effects of Latvia's membership in the EU are not limited to the Ministry of Foreign Affairs. Information provided by the Ministry of Foreign Affairs shows that currently a total of 34 specialised attachés work at Latvia's Permanent Representation to the EU from the Ministries of Defence, Economics, Finance, the Interior, Education and Science, Culture, Welfare, Transport, Justice, Environmental Protection and Regional Development, Health and Agriculture as well as from the Saeima and the Bank of Latvia. The career opportunities that have been opened for diplomats by Latvia's accession to the EU are an important aspect in Europeanization of foreign policy. Information collected by the Ministry of Foreign affairs shows that, at present, nineteen Latvian diplomats work at the European External Action Service and EU Delegations to third countries, the European Commission, and the General Court of the European Union.

Finally, Europeanization of Latvia's foreign policy also involves a societal dimension. Here, both general public opinion on Latvia's membership in the EU and the general notion of the further development of the EU, as well as the general view on EU common foreign policy, and CSDP are essential. Although the people's vote in 
the referendum on accession to the EU in September 2003 was convincing - $67 \%$ of those who participated in the referendum voted for accession to the EU - at the same time this was also the second-lowest rate among all candidate states that held a referendum on membership in the EU. Public opinion surveys conducted in Latvia prior to 2003 indicated that people's view on integration with the EU had been rather cautious (Ozolina, 2005). Although Latvia's people are not among the most ardent EU supporters, in general public opinion about the EU is positive or at least neutral (Eurobarometer 91, 2019). However, over time, the public view of the EU has been influenced by various internal and external factors, such as the economic and financial crisis, the migration crisis, terrorist attacks in France, Belgium and the other EU Member States as well as the Covid-19 pandemic. Public opinion surveys show that people's view on EU foreign policy is much more positive than with respect to US and Russian foreign policy and respondents support further integration of EU defence. However, they look cautiously at the EU's future: $63 \%$ of respondents believe that life in the EU in the coming twelve months will worsen, $42 \%$ believe that, in ten years, the EU will be less integrated (the opposite opinion is expressed by $29 \%$ of respondents), and $60 \%$ of respondents believe that the EU will become weaker after the Covid-19 crisis. Albeit only $21 \%$ of respondents express the opinion that the EU is going to collapse, $71 \%$ of respondents, in turn, do not hold this view (TAP public opinion survey, 2020). Thus, people believe that EU integration could decrease but feel sure about its continuous existence.

\section{Europeanization of Latvian-Russian Relations}

Since the restoration of Latvia's independent statehood in 1991, Russia's presence in foreign and domestic policy has been noteworthy. Latvia's foreign policy could be quite different if not for the threat caused by Russia, which demands looking for trusted allies. The Russian factor has also been constantly present in Latvia's domestic policy, although the opportunities for Russia's impact have gradually decreased. While Russia's constant presence influences Latvia's domestic and foreign policy, Latvian-Russian bilateral relations have been quite modest. Predominantly, these relations have been remote and are characterised by Latvia's rather successful efforts to decrease Russia's impact on Latvia's foreign and domestic policy. Relations with Russia have attracted major attention on the part of researchers (Muižnieks, 2006; Muižnieks, 2011a; Ozoliņa, 2008; Pelnēns, 2009; Muižnieks, 2008; Muižnieks, 2011b; Sprūds un Rostoks, 2009; Sprūds, 2012). Despite the freeze in relations between Western countries and Russia, Latvia continues dialogue with Russia and bilateral cooperation on the level of experts and sectors.
However, pragmatic cooperation has so far not given a positive impulse for fundamental changes in the relations between both states. Disagreements between both states are more noticeable in public space and acrimony relating to falsification of history is regularly aired on Twitter.

To what extent has accession to the EU influenced Latvia's relations with Russia, or, to put it differently, to what extent has Latvia's foreign policy with respect to Russia been Europeanized? If Europeanization is interpreted as approximation between the EU's common position and the individual positions of the Member States, then approximation has happened; however, this is not indicative of Latvia's approximation with the common position of the EU states towards Russia - quite the contrary. As Gunda Reire notes, currently Latvia's view on the relationship between the EU and NATO and Russia could be characterised by the phrase "We told you so" (Reire 2020, 303). Following the annexation of Crimea, the EU's common position has approximated Latvia's position, which was caused by the foreign policy of Russia itself - disrespect for the sovereignty of states, using military force against Ukraine, disinformation campaigns, interference in elections, assassinations on the territory of EU Member States, cyber-attacks against EU Member States and blatant demonstration of its military power. Russia has antagonised states that previously had been rather well disposed towards it, such as Germany, France, Italy, and the Netherlands.

Upon acceding to the EU, Latvia had to reckon with the existing framework of Latvian-Russian relations. At that time the prospects for development of Latvian-Russian relations were positive, as evidenced by the partnership and cooperation agreement between the EU and Russia, concluded in 1997, regular EU- Russia summits, the 2003 Petersburg agreement on creating four common spaces, and negotiations for a visa-free regime. Russia's proposal to offer Kaliningrad as the pilot region for EU-Russian relations was still in recent memory. With the development of good relations with the EU, Russia had grounds to hope that the new Member States would have to adjust to the common tone of EU-Russia relations. This would mean that Russia would be able to reach agreement on issues important for it with the larger EU Member States, marginalising the new Member States. Possibly, Russia would even manage to convince the "old" EU Member States to exert pressure on the "new" Member States in matters significant for Russia, such as finding a solution to the problem of non-citizens, ensuring the Russian language the status of the second official language in Latvia, and the issue of Russian schools.

Latvia's accession to the EU provided additional opportunities for resolving some issues where previously no progress had been achieved. The Border Treaty was finally signed in 2007. Politicians from several EU Member States had facilitated the signing of the Border Treaty by referring to this matter in negotiations with 


\section{Basic principles of EU foreign policy in relations with Russia}

1. EU foreign policy vis-à-vis Russia can change substantially only upon the condition that the Minsk agreement is implemented.

2. The EU wishes to pursue closer relations with the Eastern Neighbourhood states, including the states of Central Asia.

3. The EU's resilience must be reinforced, e.g., energy security, strategic communication, resilience against hybrid threats.

4. Selective cooperation is possible with Russia on issues important for the EU.

5. The development of civil society in Russia needs to be supported and people-to-people contacts must be promoted between the peoples of the EU and Russia.

Source: Council of the European Union, 2016.

Russia's representatives (Muižnieks, 2011a, 77). Likewise, in the course of preparing the visit of President Valdis Zatlers to Russia in 2010, Finland and Germany provided assistance (Bruge, 2017, 221-222). President Zatlers' visit was unable to achieve permanent improvements in Latvian-Russian relations; however, it was significant for Latvia's relations with the other EU Member States. Since accession to the EU, Latvia had been regarded as a state with a biased view on Russia in that it was influenced by the fear that had originated historically and preventing Latvia from seeing that contemporary Russia was not the Soviet Union that had occupied Latvia in 1940. Efforts to improve relations with Russia were important to demonstrate to the other EU Member States that Latvia was attempting to develop good and pragmatic neighbourly relations with Russia. If these attempts failed, the Russian rather the Latvian side was to blame.

Russia's aggression against Ukraine made the existing model of cooperation between the EU and Russia impossible. The change of the EU common position did not happen as a result of pressure exerted by some Member States but rather should be considered as being a logical response to Russia's actions. Notwithstanding some statements that the economic sanctions imposed against Russia should be lifted, the EU common position has not significantly changed; moreover, the EU has managed to retain unity. Over time, the sanctions have been reinforced, putting new surnames and organisations on the sanctions list. In part, this is linked to the situation in Ukraine, for example the construction of a bridge over the Kerch Strait; however, the unity of the EU Member States is also based on Russia's actions unrelated to the annexation of Crimea and the military conflict in the Donbas Region. For instance, at the end of July 2020, the EU introduced sanctions against several Russian persons and organisations in connection with the organisation of cyberattacks against the EU and its Member States (Council of the European Union, 2020).
Since 2004, many changes have occurred both in Latvia-Russia and the EU-Russia relations. Russia's attempts from the 1990s to impact Latvia's domestic policy and discredit it internationally have not been particularly successful. Over the last 16 years, Russia's impact in Latvia has decreased even more and, to a certain extent, this is an outcome of Europeanization. Latvia's economy has become more diversified and less dependent on Russia. The number of Russian speakers (non-citizens, in particular) has continued to diminish, and Russia's protests against the reform in education have been unable to stop it. The social democratic party "Harmony" has failed to become an acceptable partner in the process of establishing a government, and its activities in the Riga City Council are accompanied by scandals related to corruption and waste. Public opinion polls show that Russia's foreign policy is assessed positively only by $23 \%$ of respondents in Latvia, whereas $57 \%$ of respondents view it negatively (TAP public opinion survey, 2020). It can be concluded that the EU has had a limited impact on the way Latvia views Russia, and Latvia has remained cautious with respect to Russia. Moreover, over time the position of the other EU Member States has approximated to Latvia's view on Russia.

\section{Europeanization and Latvia's participation in the Common Security and Defence Policy}

Nowadays, one of the most dynamic areas of EU integration is the Common Security and Defence Policy (CSDP). At the same time, this is an area which potentially may improve or worsen Latvia's security, depending on the direction in which this policy will evolve. When, in the spring of 2004, Latvia became a Member State of the EU and NATO, the following were described as the benefits of membership in these 
organisations - welfare (EU) and security (NATO). Latvia's involvement in European security and defence policy was overshadowed by US support for the war in Iraq in 2003, with the USA at the time driving a wedge in relations between "the old" and "the new" EU Member States. Lack of enthusiasm in Latvia's position towards integration of EU security and defence could be explained by disbelief on the part of Latvia and other new Member States in the EU's ability to agree on precisely defined priorities and create a mechanism that would help to implement an effective CSDP (Ozolina, 2008b). Although approximation of the Member States in foreign policy had been ongoing in the EU since the 1980s, Latvia nevertheless did not perceive membership in the EU in terms of security. It could be predicted that EU membership would also have an impact on Latvia's security; however, this would rather manifest itself as soft security (in contrast to hard security). The EU Member States had ambitions in the area of foreign and security policy, whereas Latvia linked its security with the security guarantees included in Article 5 of the NATO Treaty and the involvement of the USA in reinforcing European security (Riekstinš, 2020). At the time, the prevailing view on European security was that "Europe has never been so prosperous, so secure or so free" (Council of the European Union, 2003). Additionally, Russia was still regarded as a complicated partner rather than an adversary.

The EU arrived at developing a common defence policy as the result of a prolonged process. EU foreign relations also involve a security dimension, so it is logical to create a common security policy, allowing the EU to use civil and military instruments in resolving international crises and peacekeeping. Currently, there are many reasons for integration in the defence area, most often related to doubts about the stability of transatlantic relations and deterioration of international security. It is possible that, in the future, the EU might have to defend its security interests autonomously, without US support. Responding to China's growing power, US military involvement in the region of Asia and the Pacific Ocean has gradually increased, decreasing the US military presence in Europe accordingly. Concerns regarding the stability of US security guarantees have increased since 2017 when Donald Trump entered office as US President. Likewise, the internal balance of power and the dynamics of international relations have been altered by the United Kingdom's secession from the EU, opening development possibilities for German and French initiatives in the defence area. The US invasion of Iraq and the overthrow of the regime of Muammar Gaddafi in Libya have, along with other factors, deteriorated the security situation in the Middle East and North Africa. In turn, Russia's aggression against Georgia and Ukraine has deteriorated security in Eastern Europe and the Caucasus region.

Latvia used to take a cautious view of close EU integration in the area of defence, which has been regarded as a potentially perilous process, the outcome of which might decrease Latvia's security if European defence integration weakened NATO. However, due to an advantageous coincidence of circumstances, defence integration might bring beneficial outcomes for Latvia. In the worst-case scenario, EU defence integration might lead to the weakening of transatlantic ties and US involvement in decreasing European security (thus weakening NATO, duplicating the activities of the alliance and ineffective use of its already limited resources intended for the defence sector). If the interests of the larger EU Member States - France, Germany, Spain and Italy - were to prevail, this would not align with Latvia's interests, as this could result in exaggerated orientation of the CSDP towards stabilising the continent of Africa and the fight against terrorism, paying less attention to the security needs of the Member States in the eastern part of the EU. However, a benevolent scenario is also possible, where the EU Member States reinforce their military capabilities, taking into account the interests of the Member States from both the northern and southern regions of the EU, maintaining active involvement of the USA and ensuring EU-NATO cooperation. These considerations have influenced Latvia's position. Although Latvia's involvement in some EU defence initiatives such as Permanent Structured Cooperation (PESCO) has been questioned, in general EU defence integration has been viewed as an inevitable process that requires involvement. In the coming years, Latvia will undoubtedly become involved in discussions on the direction that development of the EU defence area will take and how rapid that development will be. In this respect, discussions for preparing the EU's "strategic compass" will be essential.

Latvia's interests in the CSDP and participation in EU defence initiatives are determined by several considerations. From the Latvian perspective, EU efforts in the defence area could only supplement measures implemented by NATO, avoiding duplication. Also in the future the CSDP should be an area in which decisions are adopted unanimously. Preservation of the status quo is of particular importance after the UK exits from the EU because, with a qualified majority vote system, the possibilities for smaller states to block decisions will decrease significantly (McCarthy, 2019). Latvia is also ready to contribute to EU operations in the future; however, it should be taken into account that, historically, Latvia has been more involved in NATO operations. In view of the limited resources available, there are concerns that it might be difficult for Latvia to participate in EU operations, which in turn might lead to a decrease in Latvia's influence on decision-making. Latvia is also interested in balanced further development of the CSDP, that is, so that this policy would include in its range of attention not only the states of Africa and the Middle East but also the Eastern neighbouring states of the EU. Promoting competitiveness and cooperation in the EU defence industry is an important element of the defence 
area. In this respect, Latvia is interested in development of the defence industry of the EU Member States of a kind that would also facilitate development of the defence industry in smaller states. This issue is essential for Latvia and should be examined not only in the context of security of supply but also in the context of EU financing for the defence industry. Finally, for Latvia, it is important that, within the framework of the CSDP, attention should also be paid to non-military threats, in that the EU would contribute significantly to the prevention of disinformation, cyber threats and hybrid threats. In this area, Latvia has noteworthy experience and competence that ensures the visibility and protection of its interests.

As for now, the general development of the CSDP is compatible with Latvia's interests. Efforts by EU states to reinforce their military capability is a step in the right direction. Latvia has become involved in projects that reinforce its security, such as those involving military mobility as well as autonomous land and underwater technologies. Earlier concerns that the vitally important security interests of Latvia and other countries of the EU North-eastern region would not be taken into consideration have not materialised. To a large extent, this is due to Germany's responsible approach to the security of the Baltic States and Poland (and threats posed by Russia). Assessment of Europeanization in the defence area allows the conclusion that it is compatible with Latvia's interests and allows retention of autonomy in matters of genuine importance for Latvia.

Integration in the defence area also has a public dimension, which evidences that people in Latvia hold quite a positive view on EU defence integration. A public opinion poll, conducted in the framework of the Human Development Report (HDR), reveals that $61 \%$ of respondents view EU foreign policy positively, whereas $21 \%$ of respondents have a negative view. People in Latvia hold a rather positive view on the possibilities of closer cooperation in the area of defence - $56 \%$ of respondents believe that the EU Member States should strive for closer integration in the defence area in order to achieve greater military independence from the USA, even if that would mean a significant increase in defence expenditure, while only $25 \%$ of respondents do not support this view (TAP public opinion survey, 2020). The Ministry of Foreign Affairs and the Ministry of Defence take a cautious position vis-à-vis the CSDP (although, in general they are proactive), which implies that Europeanization in the area of security and defence has been limited. However, the results of the HDR public opinion survey indicate that society would support further EU security and defence integration.

\section{Europeanization and Latvia's development cooperation policy}

It would not be a great exaggeration to state that development cooperation policy became part of Latvia's foreign policy due to EU accession. At the same time, development cooperation policy evidences that Latvia's foreign policy is influenced not only by the EU but also by the broader international context and domestic policy factors such as public opinion. Latvia's involvement in providing assistance to other countries points to the limits of Europeanization in that the EU strongly influences development cooperation policy as implemented by Latvia; however, Latvia may provide bilateral development cooperation in accordance with its own notions as to which states and in what amount assistance should be provided. Latvia's development cooperation policy complies with internationally recognised ideas about the aims and means of providing assistance; however, its objective is also to reinforce national security and increase Latvia's international recognisability as a donor state.

The EU's role in embedding development cooperation policy in Latvia has been decisive. Since 2004, great attention has been focused on researching these issues in Latvia (Ignatāne, 2006; Latvijas intereses Eiropas Savienībā, ${ }^{1}$ 2014/3; Timofejevs-Henriksson, 2015). The year 2004 was the line of demarcation for Latvia, marking its transformation from a beneficiary state into a donor state; however, in 2004 Latvia was one of the poorest EU Member States. Even now nothing much has changed in this respect, as evidenced by an agreement reached in the summer of 2020 regarding the EU multi-annual budget, from which Latvia will receive much more than it pays in. The income of Latvia's people lags behind not only the "old" EU Member States but also behind Lithuania and Estonia. It is not surprising that Latvia's people compare their prosperity with the other EU Member States rather than with the poorer developing countries in other regions of the world. This makes ensuring political support for development cooperation policy difficult.

Although the arrival of development cooperation policy in Latvia was determined by Latvia's accession to the EU, Latvia has tried to retain its autonomy both with respect to the amount of financing and the choice of target countries for assistance, which has led to failure to meet its international commitments. The national-level visibility of development cooperation was not significantly influenced even by the fact that Latvian representative Andris Piebalgs served as the EU Commissioner for Development (2010-2014). Content-wise, Latvia has tried to build upon its reform experience from the past two decades. Latvia's priorities have predominantly been linked to transferring its pre-accession experience to partner states wishing to develop closer relations

\footnotetext{
1 Latvia's interests in the European Union.
} 
with the EU. Also in recent years, Latvia has mainly chosen to provide development assistance to reinforce good governance, democracy, respect for human rights, gender equality and environmental sustainability in partner countries (Ministry of Foreign Affairs, 2020a).

The coming years will see the growing importance of digitalisation as the horizontal priority in Latvia's development cooperation policy. Predominantly, Latvia has chosen as assistance beneficiary states the countries of the Eastern Partnership Region - Moldova, Ukraine and Georgia - as well as the countries of Central Asia Kirghizstan, Tajikistan, and Uzbekistan. As regards the selection of target countries, Latvia's choices related to provision of assistance differ from the choice made by the countries of Western Europe. Latvia does not assist the poorest countries, and its bilateral development cooperation policy is almost not implemented at all in partnership with countries of Africa, South America, and South Asia. Arguably, Latvia's development policy has two functions. On the one hand, its aim is to foster the development of partner states. On the other hand, its aim is to reinforce Latvia's national security.

The impact of Europeanization has also been limited with respect to financing allocated. Although total financing for development cooperation policy has increased, Latvia nevertheless mostly provides multilateral assistance. Upon accession to the EU, Latvia provided more than $90 \%$ of assistance multilaterally (mandatory contributions to international institutions). However, immediately after accession to the EU, it was forecast that the amount of assistance provided bilaterally should increase over time because Latvia had committed itself to increase development financing from less than $0.1 \%$ of GDP to more than $0.3 \%$ of GDP. Fifteen years later, the financing allocated for development assistance remains at approximately $0.1 \%$ of GDP, although it has increased significantly in absolute numbers. Since development assistance is usually implemented with the help of non-governmental organisations, institutions of public administration and private sector organisations, such actions by Latvia have given rise to dissatisfaction among the organisations in these sectors. Although during the last four years (2017-2020), financing for providing bilateral development assistance supervised by the Ministry of Foreign Affairs amounted to EUR 463,813, this looks modest against the background of Lithuania and Estonia, where it is many times higher. This contrast is particularly vivid in comparison with Estonia, where the amount of official development assistance in 2018 reached $0.16 \%$ of gross national income (see Table 1 for a comparison of the main parameters of Latvia's financing for development cooperation with Lithuania and Estonia). Insufficient financing has decreased the possibilities for Latvia's non-governmental organisations to apply for financing from EU development policy instruments, not to mention Latvia's possibilities for effective participation in the development of the EU's development cooperation policies.

Assessing the outcomes of Europeanization in development cooperation policy, it should be noted that Latvia's actions are influenced not only by the framework of EU development cooperation policy but also by global conditions. Upon accession to the EU, development cooperation policy was to a large extent defined by the Millennium Development Goals, whereas since 2016 Latvia's actions must be viewed in the context of implementing the Sustainable Development Goals. In view of the fact that the goals defined in the framework of the UN cover the most diverse aspects of development, development cooperation policy as implemented in Latvia is aimed at achieving the Sustainable Development Goals. Likewise, during the last decade the perception of how and by what means development can be achieved has also changed, attributing greater importance to the financing of the private sector; put differently, financing for bilateral and multilateral development assistance is insufficient, so other paths for promoting development have to be sought. In this respect, good governance and investment in development by the private sector is of particular importance.

\section{Table 1.3.1. Financing for development cooperation: Latvia compared to Lithuania and Estonia.} Data for 2018 and 2019

\begin{tabular}{cccccc}
\hline STATE & \% of GNI, 2019 & $\begin{array}{c}\text { Total amount, } \\
\text { million USD, } \\
2019\end{array}$ & $\begin{array}{c}\text { Multilateral } \\
\text { assistance, million } \\
\text { USD, 2018 }\end{array}$ & $\begin{array}{c}\text { Bilateral assistance, } \\
\text { million USD, 2018 }\end{array}$ & $\begin{array}{c}\text { MFA budget for } \\
\text { bilateral development } \\
\text { cooperation, million } \\
\text { EUR, 2018 }\end{array}$ \\
\hline Estonia & 0.13 & 42 & 34 & 22 & 11.9 \\
\hline Lithuania & 0.11 & 58 & 55 & 12 & 1.9 \\
\hline Latvia & 0.10 & 34 & 31 & 5 & 0.5 \\
\hline
\end{tabular}

Sources: Ministry of Foreign Affairs, 2020b; OECD data. 
Latvia's dual status - a donor country in global scope but a beneficiary country within the EU framework has created dual feelings in society, as evidenced by the results of public opinion polls. For instance, the results of a Eurobarometer survey conducted in 2018, show: $74 \%$ of respondents believe that assistance should be provided to the inhabitants of developing states (the EU average for this indicator is EU 89\%). However, the wording of the question does not indicate that Latvia should be the one to provide assistance. Some $49 \%$ of Latvia's respondents agreed that decreasing poverty in developing countries should be an EU foreign policy priority (the EU average for this indicator is $71 \%$ ). However, answering the question whether decreasing poverty in developing countries should be one of Latvia's foreign policy priorities, only $23 \%$ of respondents expressed support for providing assistance to developing countries (the EU average for this indicator is 54\%). There seems to be irony in this because Latvia, since its accession to the EU in 2004, has received assistance worth billions from the other Member States. Only in Estonia is support for providing assistance to developing countries to decrease poverty lower than in Latvia 12\% (European Commission, 2017-15).

Public opinion polls conducted in Latvia reveal that societal support for development cooperation is not quite clear-cut. A recent public opinion survey shows that society's interest in providing assistance to developing countries is low - only $24 \%$ of respondents believe that they are interested in EU assistance to developing countries such as African states, whereas $62 \%$ of respondents have no interest in this aspect of the EU's external relations (TAP public opinion survey, 2020). Since 2004, the number of respondents who believe that Latvia should provide assistance to developing countries has increased (SKDS, 2009); however, society has mixed feelings about providing assistance. A large part of Latvian society still does not believe that Latvia should provide assistance to developing countries and people are more in favour of providing assistance to post-Soviet states rather than to African or Asian countries. It can be concluded that the arrival of development cooperation in Latvia's foreign policy is the result of Europeanization; however, the case of this policy also points to the limits of Europeanization, determined by global processes and domestic policy terms. Development cooperation policy has not become one of Latvia's key foreign policy priorities. If the amount of bilateral assistance increases in the coming years, the reason most probably will be Latvia's decision to stand for a place as a non-permanent member of the UN Security Council.

\section{Main findings and most important tasks}

\section{Main findings}

To what extent has Latvia's foreign policy been affected by Europeanization? On the one hand, the view that Europeanization in foreign policy has been limited prevails in academic literature. In this respect, Latvia's experience does not differ notably from the experience of other Member States. Analysis of several aspects of Latvia's foreign policy confirms this. Although manifestations of Europeanization are undeniable, the impact of integration on the most significant of Latvia's foreign policy interests has been limited. For instance, although in recent years Latvia's involvement in the CSDP has gradually increased, which can be explained by the growing importance of this policy in the EU, nevertheless Latvia's primary security interests continue to be linked to its NATO membership. A similar conclusion can be drawn with respect to EU-Russia relations. Over time, the position of the EU Member States vis-à-vis Russia has approximated Latvia's view rather than the opposite, that is, Latvia's view of Russia has not changed significantly. Upon accession to the EU, development cooperation policy became an important direction in Latvia's foreign policy; however, Latvia, in contrast to the other EU Member States, has never tried to set ambitious aims for itself in this respect. These examples show that continuity has been observed in Latvia's foreign policy and that the impact of Europeanization has been limited.

On the other hand, Europeanization of Latvia's foreign policy is undeniable, as is manifest both in its content and institutions as well as in public attitudes. Involvement in development of the EU's foreign and security and defence policy has created the need to define interests in the most diverse issues and raised the level of competence in those matters that were of minor importance for Latvia prior to its accession to the EU. Institutional changes have also taken place, in the sense that Latvia's accession to the EU meant a significant expansion of foreign policy representation in Brussels, while at the same time the importance of diplomatic representations in EU Member States decreased slightly. On the level of individuals, adding a European dimension to Latvia's foreign policy meant - for foreign service staffers - opportunities for growth and better remuneration at the EU institutions. Europeanization has changed the view of Latvian society on the EU's global role, and in general Latvia's people have a much higher regard for EU foreign policy than for the foreign policy of Russia and the USA. Possibly, EU foreign policy is increasingly understood by society as "our" foreign policy. 


\section{Most important tasks}

For Latvia, the first 16 years in the European Union have not been simple. The deep economic recession has been weathered, Latvia's first presidency at the EU Council has been conducted, and the migration crisis also seems to be in the past. However, awareness is needed that the next 16 years could be even harder. Substantial changes are occurring in the world - international competition is intensifying, which may increase discord within the EU and between the EU and some other key international actors such as China and Russia. Many things that previously seemed self-evident - such as active involvement by the USA in reinforcing the security of the EU - can no longer be taken for granted. Latvia must take into account that in the future diplomats might have to represent Latvia's interests in much more troubled waters not only internationally but also within the EU framework. Possibly, Turkey's delay in supporting the NATO defence plan for the Baltic States at the end of 2019 and Cyprus' opposition to EU sanctions against Belarus are the first signs that Latvia might have to work harder in the future to achieve its foreign policy aims.

An important task for the coming years will be to further strengthen the professional and academic competence of foreign policy. Membership in the EU and NATO demands noteworthy competence from Latvia in diverse matters of international relations; however, the competence available within the state is often limited. It is a matter for discussion whether Latvia's competence, for example with respect to Russia, is based on in-depth knowledge of the domestic and foreign policy of that country or on suspicions, intensified by historical experience, regarding Russia's intentions and conduct in international politics. Sometimes even erroneous analysis leads to the right conclusions. Unfortunately, over a longer period, such an approach inevitably leads to an erroneous assessment of other states' conduct. Although it is impossible to be totally error-free in foreign policy, it would be advisable to base judgements about international policy on in-depth knowledge rather than intuitive evaluations. In this respect, Latvia has significant opportunities for improvement. 


\subsection{Europeanization of the Latvian economy}

\section{Morten Hansen}

\section{Introduction}

Latvia's development since 1991 has been characterized by an anchoring of its western orientation through consistently seeking membership of the key supranational organizations promoting democracy, free trade and free market economics (see Box 1.4.1.). Specifically, EU membership provided access to free trade inside the EU, while accession to the Eurozone on the one hand facilitates trade while, on the other hand, defines monetary policy. The economic impact of OECD membership, however, is more related to structural reforms of the economy.

Latvia's integration into these institutions and institutional arrangements is so deep that it only shares all these memberships with a dozen other countries. How has this impacted economic development and economic policy making?

This chapter is organized as follows: Latvia's economic position and development is presented in context with the Former Soviet countries with which it shared an integrated planned economy as well as the EU. Developments of international trade and its stance in terms of FDI are discussed. The major impact on Latvia, in terms of EU institutions, comes from joining the Single Currency in 2014. The impact this has had on Latvian legislation - changes to the Bank of Latvia Law, observance of the Maastricht criteria, the establishing of the
Fiscal Discipline Council - as well as on economic policy is then discussed at length. The final section wraps things up and makes some broader conclusions.

\section{Latvia's economic development}

The Soviet Union may have been a union by name but certainly not in terms of economic performance. At the time of Latvian independence and the general break-up of the Soviet Union in the early 1990s, massive economic disparity inside the union was a fact, with the Baltic republics, the Russian Federation and oil-rich Kazakhstan being the most affluent republics as can be seen from Figure 1 . Since the mid-1990s, the Baltic countries have economically outgrown the Russian Federation and now represent the three richest former Soviet republics, closely followed by Russia and Kazakhstan but significantly ahead of neighbouring Belarus and far ahead of Ukraine and Moldova as well as the other Asian republics. ${ }^{1}$

Whereas Figure 1.4.1. speaks of an economically strong Latvia, when compared to most FSU countries, Table 1.4.1. indicates a similar trend but in terms of institutional strength and economic-political predictability. It provides the sovereign ratings by Standard \& Poor's (or Moody's if no rating by Standard \& Poor's is available) for the EU28 and the CIS countries. ${ }^{2}$

\section{Box 1.4.1.}

\section{Year of Latvia's accession to major supranational organizations}

- United Nations (UN), 1991

- International Monetary Fund (IMF) \& World Bank (WB), 1992

- Organization for Security and Cooperation in Europe (OSCE), 1993

- World Trade Organization (WTO), 1999

- North Atlantic Treaty Organization (NATO), 2004

- European Union (EU), 2004

- Schengen Zone, 2007

- Eurozone (technically known as the Euro Area), 2014

- Organization for Economic Cooperation and Development (OECD), 2016

\footnotetext{
1 Data from before 1995 is not provided for all countries by the IMF and may be highly uncertain; thus 1995 is chosen as the early reference point.

2 As of 12 July 2020.
} 


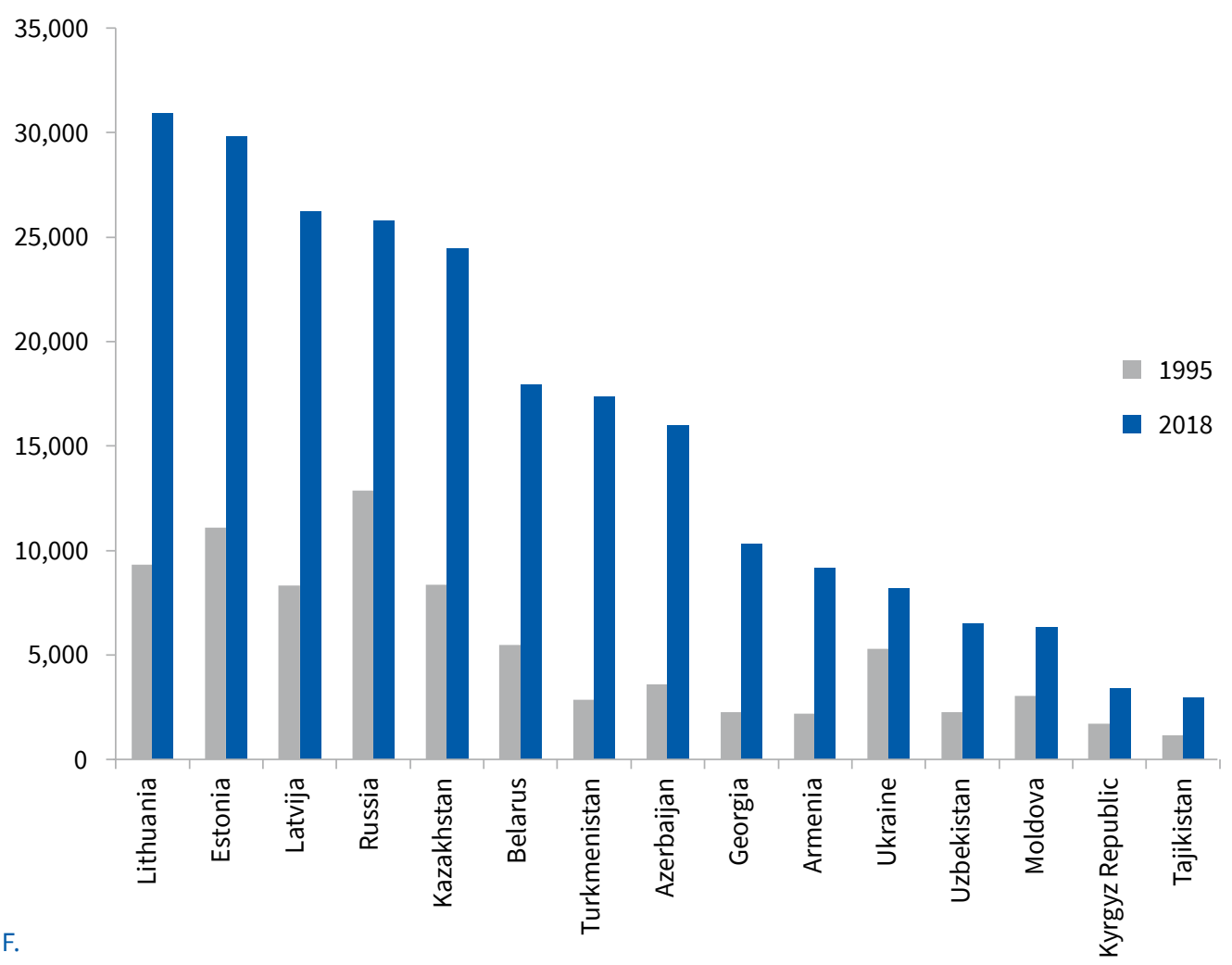

Source: IMF.

\section{Table 1.4.1. Sovereign credit ratings for EU28 countries and for CIS countries}

\begin{tabular}{cc}
\hline Rating & Countries \\
\hline AAA & Investment grade \\
\hline AA+ & Denmark, Germany, Luxembourg, Netherlands, Sweden \\
\hline AA & Austria, Finland \\
\hline AA- & Belgium, France, United Kingdom \\
\hline A+ & Czechia, Estonia, Ireland, Slovenia \\
\hline A & Latvia, Lithuania, Slovakia \\
\hline A- & Spain \\
\hline BBB+ & Malta, Poland \\
\hline BBB & Bulgaria \\
\hline BBB- & Hungary, Italy, Portugal \\
\hline & Speculative grade \\
\hline BB+ & Azerbaijan \\
\hline BB & Croatia, Cyprus, Kazakhstan, Romania, Russia \\
\hline BB- & Georgia, Greece \\
\hline B+ & Armenia*, Uzbekistan* \\
\hline B & Belarus, Kyrgyzstan ${ }^{\star}$, Ukraine \\
\hline B- & Moldova*, Tajikistan* \\
\hline
\end{tabular}

Source: Standard \& Poor's (2020), Moody's (2020).

Countries marked with $a^{*}$ are not rated by S\&P. Their ratings here are the equivalent from Moody's. None of the three large ratings agencies rate Turkmenistan. 
Latvia's sovereign rating with Standard \& Poor's

\begin{tabular}{cc}
\hline Date & Rating \\
\hline 16.01 .1997 & BBB \\
\hline 20.08 .2002 & BBB+ \\
\hline 29.07 .2004 & A- \\
\hline 17.05 .2007 & BBB+ \\
\hline 27.10 .2008 & BBB \\
\hline 24.02 .2009 & BB+ \\
\hline 10.08 .2010 & BB \\
\hline 10.12 .2010 & BB+ \\
\hline 02.05 .2012 & BBB- \\
\hline 09.11 .2012 & BBB \\
\hline 10.06 .2013 & BBB+ \\
\hline 30.05 .2014 & A- \\
\hline 21.09 .2018 & A \\
\hline 21.02 .2020 & A+ \\
\hline Source Standard \& Poor's (2020).
\end{tabular}

Source: Standard \& Poor's (2020).

Only three Eastern European EU members are rated above Latvia, which, with an A+ rating is safely into investment grade area, a rating the 2020 Covid-19 outbreak did not harm, unless economic development should be jeopardized by unhealthy fiscal policies, which themselves are unlikely given the significant impact of EU institutional development on Latvia's fiscal policy (such as the Fiscal Discipline Council, Maastricht Criteria, 6-pack, 2-pack which are discussed later in this section).

Table 1.4.1. also reveals the uncertainties that concern the international ratings agencies surrounding economic policy and economic development in the CIS countries: Nine of the eleven CIS countries are rated speculative with Kazakhstan and Russia just barely above speculative grade.

Furthermore, the table clearly reflects the northsouth divide of the EU where not a single southern European country is rated triple-A, instead several languish at low ratings and Greece even, at BB-, in speculative territory. The Baltic states have clearly set themselves apart from the poor ratings of the south, not least after their recovery from the 2008-2010 financial crisis and later adoption of the euro.

Latvia's ratings have been clearly influenced by the road to the EU and the stability of membership of the Euro Area, as seen in Box 1.4.2. Latvia was elevated to A- by S\&P shortly after EU accession in 2004 and again, following the financial crisis and its many credit writedowns, to A- a few months after euro adoption in 2014.

In comparison to other EU member states, however, Latvia is still among the poorer countries with average income as measured by GDP per capita at $69 \%$ of the EU27 level in 2019, only ahead of Romania, Greece, Croatia and Bulgaria. Partial convergence has, however, been quite strong. In 1995, Latvia had the lowest GDP per capita among EU15 plus the ten new Eastern European member states that joined the organization in 2004 and 2007 at just over 20\% of the then EU15 average (European Commission 1997, p. 137). ${ }^{3}$

A more comprehensive picture of the partial income convergence may be gained from Figure 1.4.3. Of all the countries comprising EU28, Latvia's income growth is only exceeded by Lithuania's. In general, the new member states of Eastern Europe have fared very well since 2000, reflecting low starting points but arguably also EU membership. Also here, the North-South divide is noticeable with the northern countries having performed much better than the southern ones and with Italy even being poorer in 2019 than in 2000.

Latvia is one of the more open economies in the EU measured by foreign trade as a share of GDP. In the 1990s, imports vastly exceeded exports, as can be seen from Figure 1.4.3. This is a typical phenomenon for a growing and converging economy that borrows to

\footnotetext{
3 This would correspond to around 25\% of the EU28 level, i.e. significant partial catch-up from $25 \%$ to $69 \%$.
} 


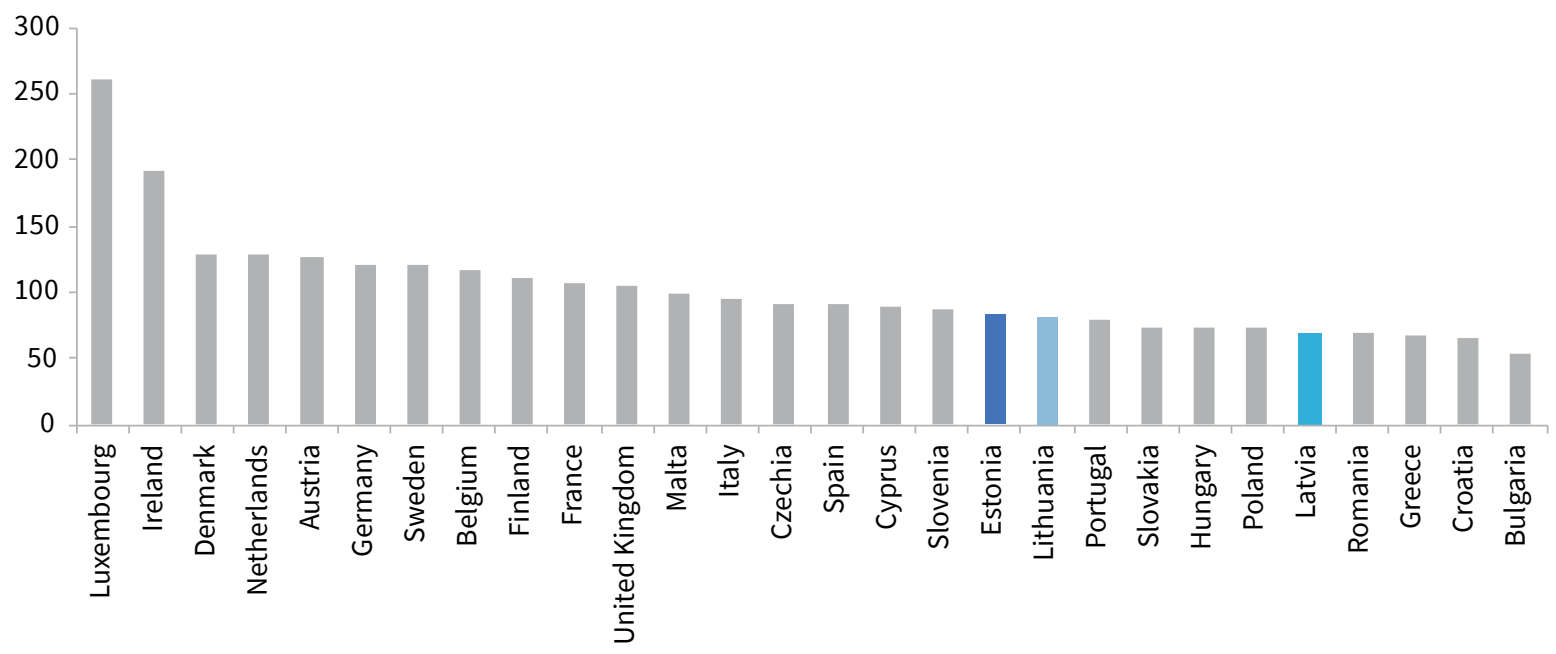

Source: Eurostat (2020).

\section{Figure 1.4.3. GDP per capita growth in \%, constant prices, EU28, 2000-2019}

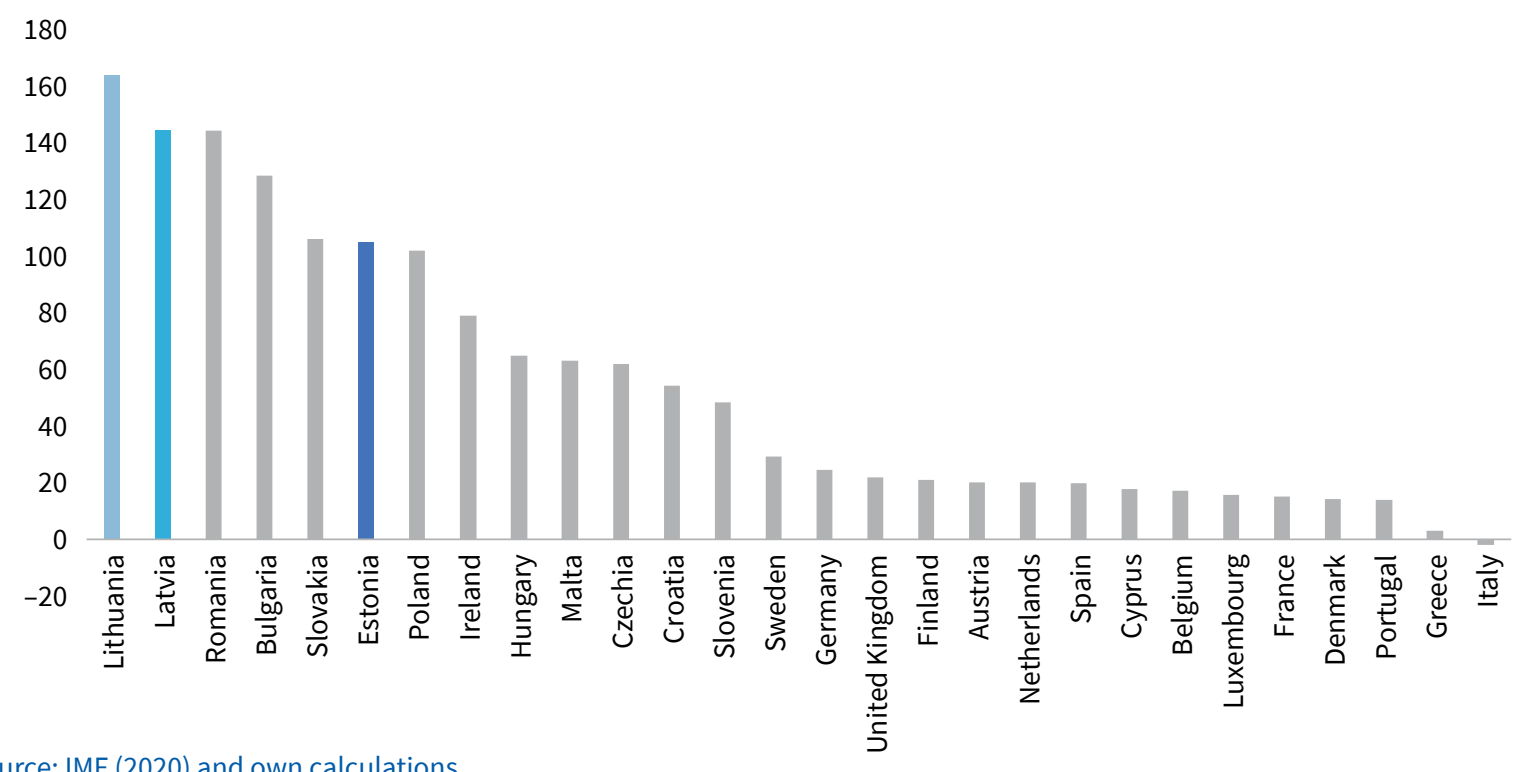

Source: IMF (2020) and own calculations.

finance substantial domestic investment. The financial crisis of 2008-2010 led to a massive drop in imports as a credit-fuelled boom turned to bust and could no longer sustain massive imports. Remarkably, the domestic economy reoriented quickly from domestic consumption towards exports, seeing exports as a share of GDP climb from around $40 \%$ to $60 \%$ of GDP, undoubtedly helped by free access to the Single Market - and helping to eradicate the vast and eventually unsustainable current account deficits of the pre-crisis era.

Reorientation in terms of trading partners was also very brisk and was a phenomenon that took place already during the 1990s. Whereas Latvian exports to the CIS countries, notably Russia, stood at some $50 \%$ in the very early 1990s, this share plummeted to around $10 \%$ by 2000 and found a new plateau at that level (see Figure 1.4.5.). Reorientation was towards the West, at first towards the old member states of the EU15 which saw its share of Latvian exports rise from $25 \%$ to $65 \%$ from 1993 to 2000 and then decline as more and more Latvian exports went to the new member states of the EU, following the $2004 \mathrm{EU}$ expansion.

This development can be seen in more detail in Figure 1.4.6. where shares of Latvian exports to various major trading partners are portrayed. Data is only available from 2000 but the picture is clear: Where 'old' EU 


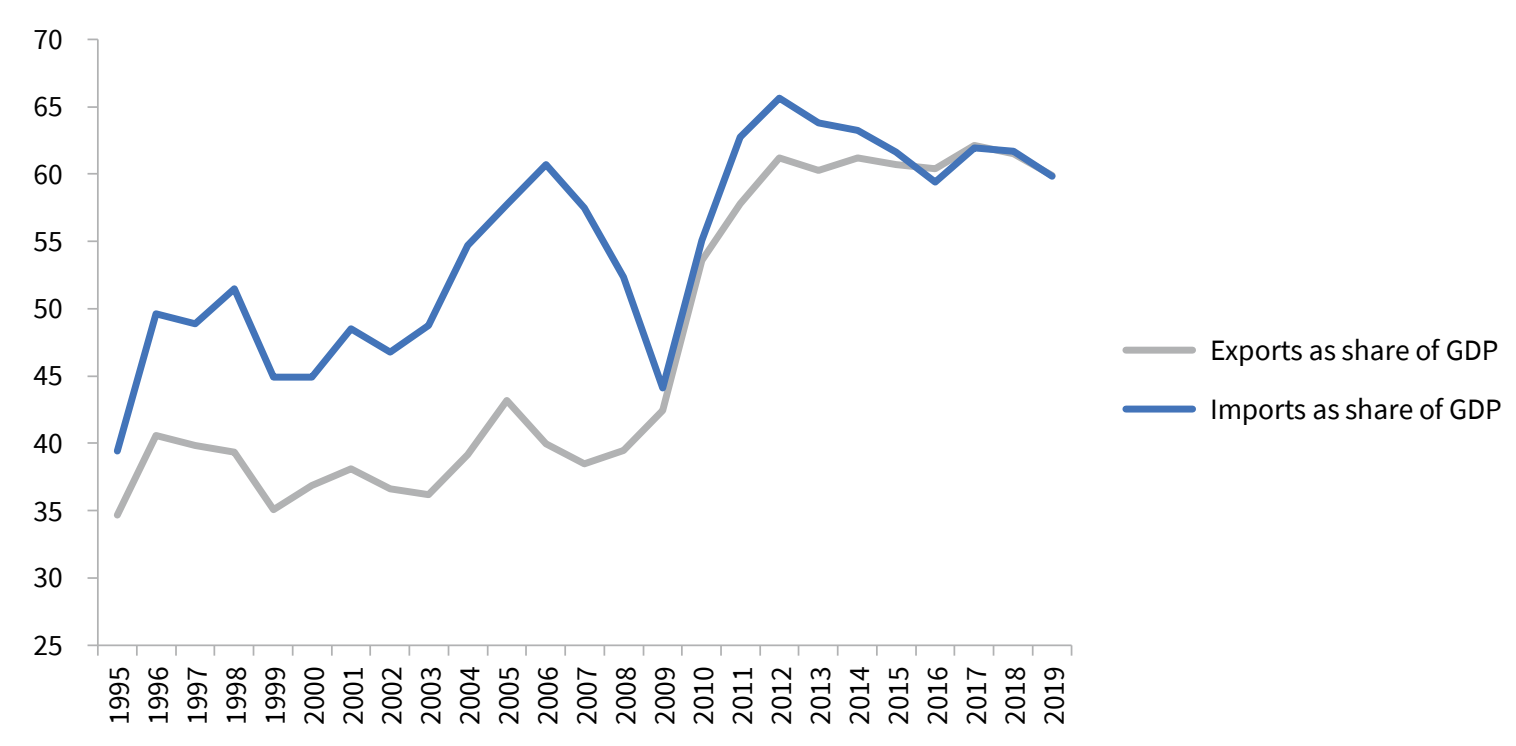

Source: Central Statistical Bureau and own calculations.

\section{Figure 1.4.5. Latvian exports of goods by major destinations, 1992-2018}

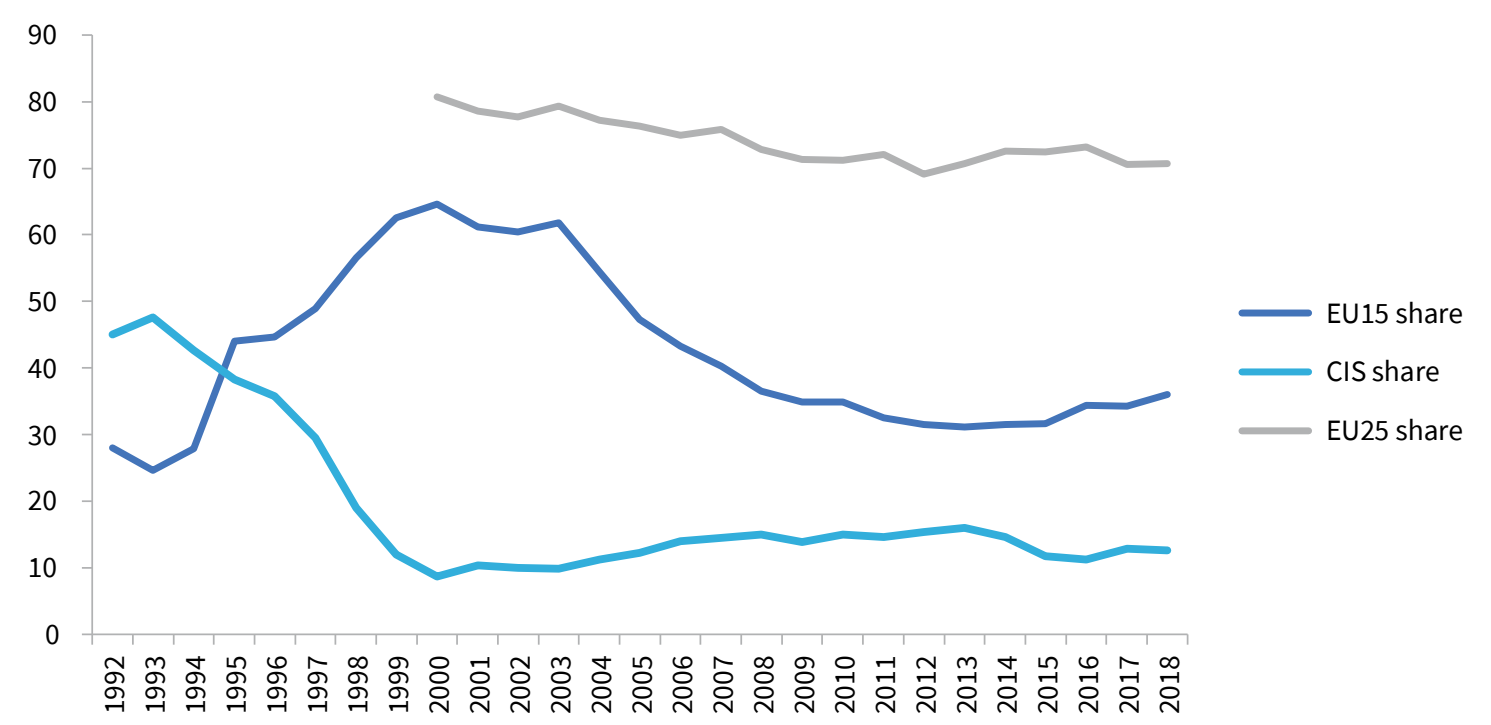

Source: Central Statistical Bureau (2020) and own calculations.

countries such as Germany, United Kingdom and Sweden were major destinations for Latvian exports in the early 2000s, accession to the EU - and thus to the Single Market - provided much easier access to the neighbouring countries and also new member states of the EU, Lithuania and Estonia. The EU and its Single Market has transformed the pattern of Latvian foreign trade, a pattern that today quite well reflects what a gravity model for international trade would predict. ${ }^{4}$

Foreign Direct Investment (FDI) in Latvia also reflects the country's reorientation towards the European Union but also a longer history of involvement with Sweden

\footnotetext{
4 A gravity model for international trade predicts more trade flows with larger economies (by population and GDP per capita), reflecting higher demand and with economies that are geographically close; distance being a proxy for cost of transportation. Thus, Lithuania, Estonia and Russia being the largest trading partners and neighbouring economies comes a no surprise. That Russia is not number one reflects barriers to free trade and the Single Market posing zero barriers. Besides free access to EU markets in general, the effect on trade is accentuated by Latvia's large ports as well as Riga being the Baltic hub for air transportation.
} 


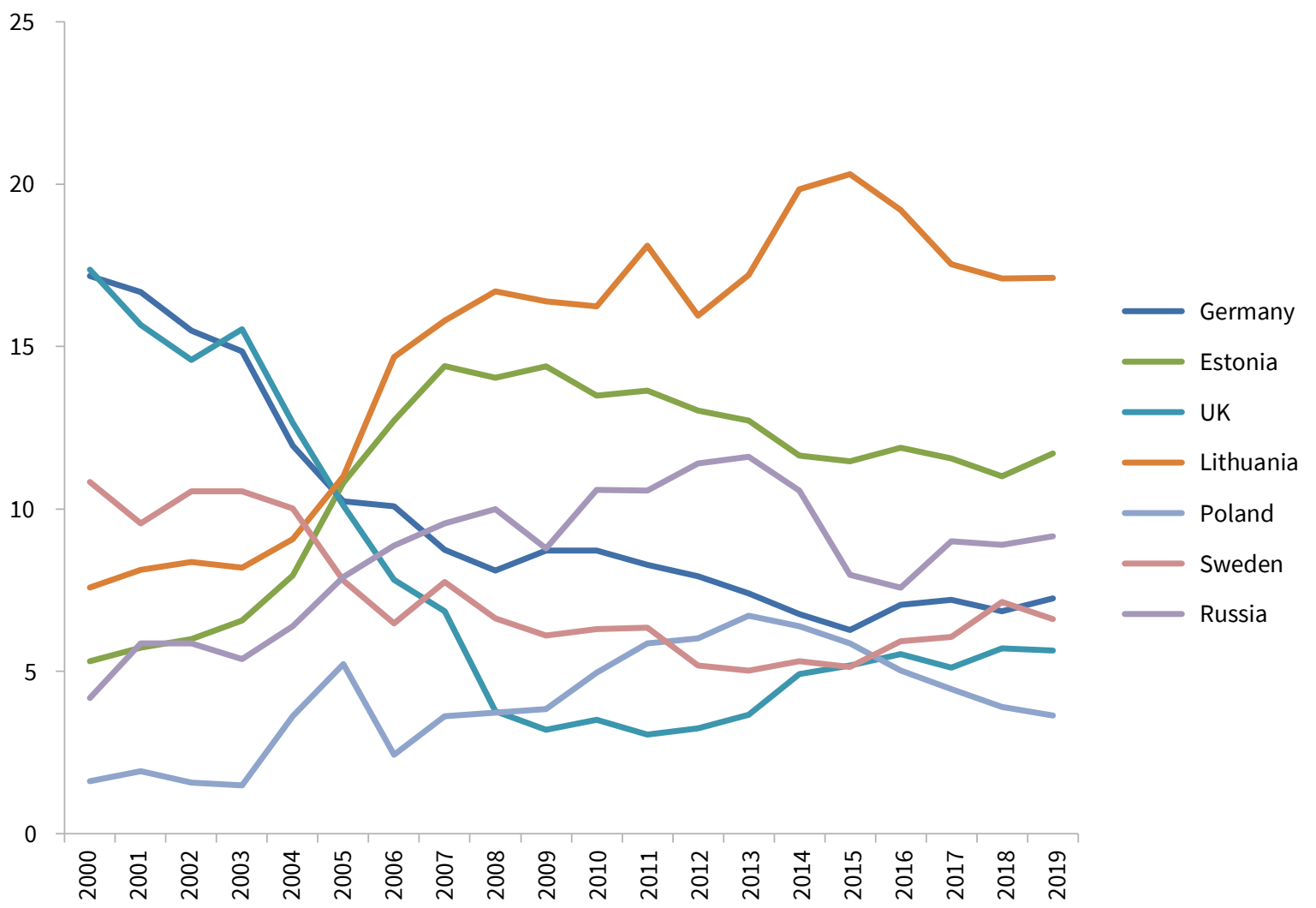

Source: Central Statistical Bureau (2020) and own calculations.

Equivalent graphs for imports are not provided since they tell a similar story.

\section{Figure 1.4.7. FDI stock in Latvia, end-2019, by countries}

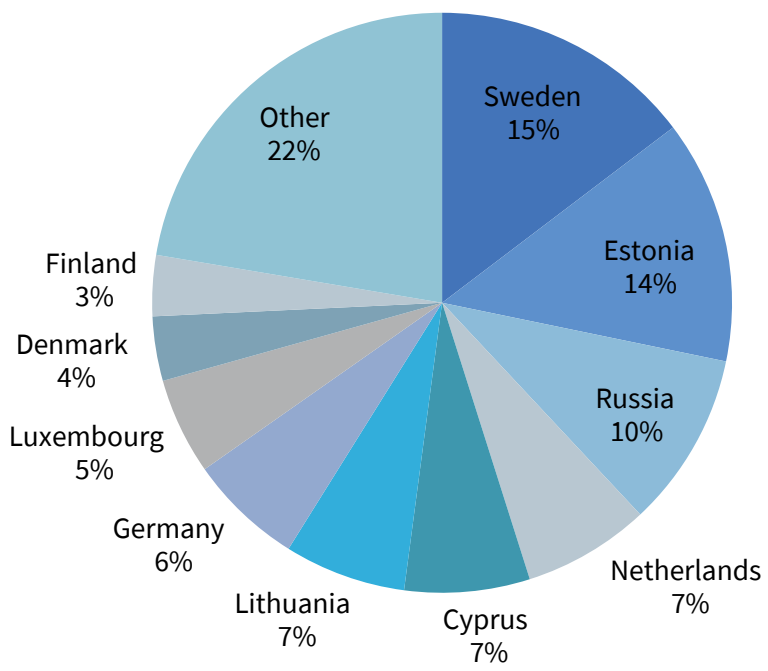

Source: Investment and Development Agency of Latvia (LIAA). 
still being the biggest investor, although the ties with Russia are even stronger. The surprise presence of Cyprus in the table reflects Russian off-shores as at least some of the presence of Luxembourg also does.

\section{From Rouble to Euro}

On 20 September 2003 Latvia voted overwhelmingly (67.5\% for, $32.5 \%$ against) for joining the EU. Since the Acquis Communautaire states that a country joining the EU should adhere to the aims of political, economic and monetary union, Latvia's central bank, the Bank of Latvia, issued a statement on 21 September 2003 (Bank of Latvia, 2003), i.e. just one day after the referendum, stating Latvia's plans for preparing to join the Eurozone.

The Latvian currency, the lat, had been pegged since 1994 to the IMF's hybrid currency, the SDR (Special Drawing Rights). A first step towards adopting the Euro, also required by the Convergence criteria, TFEU Article 140, (known as the Maastricht criteria) is a fixed exchange rate to the euro within ERM II (Exchange Rate Mechanism II) of the EMS (European Monetary System). On 21 September 2003 the Bank of Latvia announced that such a re-peg to the euro would take place on 1 January 2005, when the market value that day of lats to euro, $0.702804 \mathrm{LVL} / \mathrm{EUR}^{5}$, the so-called parity rate of the lat vis-à-vis the euro. The exchange rate criterion stipulates that the lat must remain in ERM II without devaluation for at least two years before fulfilling this criterion for euro adoption. In the same press release, entering ERM II was envisaged for 1 January 2005 but it was just slightly delayed to 2 May 2005 (Bank of Latvia, 2011).

Article 140 in TFEU calls for other factors to be examined, too (e.g. financial sector integration with the Eurozone as well as the stance of the current account balance) but these other factors have never hindered euro accession for a country that fulfilled the five Maastricht criteria. It seemed obvious at the time that Latvia fulfilling the five criteria would ensure euro accession; this being the first country to join the Euro Area following the financial crisis.

\section{Box 1.4.3.}

\section{The Maastricht (Convergence) criteria}

Article 140 of the Treaty on the Functioning of the European Union provides the criteria that must be fulfilled for an EU member state with a derogation to join EMU (TFEU, Article 140), the Economic and Monetary Union, i.e. the Eurozone. Protocol No 13 then provides the details that can be summarized as follows:

- Price stability criterion: To join the single currency, a country's inflation rate ${ }^{6}$ must not exceed the average of the three best-performing countries ${ }^{7}$ plus 1.5 percentage points. At the time of assessment (April 2013), the three best-performing countries were Sweden, Ireland and Latvia ${ }^{8}$ with a criterion of $2.7 \%$ and Latvia's inflation at $1.3 \%$.

- Exchange rate criterion: The country's exchange rate must have participated in ERM II of the EMS for at least two years without devaluation. Since Latvia had maintained its fixed exchange rate vis-à-vis the euro inside ERM II since 2 May 2005, this criterion was fulfilled.

- Long-term interest rate criterion: The country's long-term interest rate ${ }^{9}$ must not exceed the average of the three best-performing countries ${ }^{10}$ plus 2.0 percentage points. The same three best-performing countries as mentioned in terms of price stability produced a criterion of $5.5 \%$ while Latvia's long-term interest rate stood at $3.8 \%$.

- Budget deficit criterion: The country's government budget deficit must not exceed 3\% of GDP. Latvia's deficit, for 2012 (the last full year before evaluation), was 1.2\% of GDP, well below the criterion.

- Government debt criterion: The country's government debt must not exceed 60\% of GDP. Latvia's debt ratio, for 2012 , was $40.7 \%$ of GDP, also here well below the criterion.

\footnotetext{
5 Thus the lat neither devalued, nor revalued on the day of re-pegging.

6 Not the usual, year-on-year inflation rate but the longer measure of the past 12 months over the previous 12 months.

7 I.e. the three EU countries - not Eurozone countries - with the lowest inflation rates.

8 Since Latvia was thus compared to itself, the country could not fail this criterion!

9 Sovereign bonds with at least ten years to maturity.

10 The three best-performing in terms of inflation, not interest rates.
} 
Latvia joined the Eurozone 1 January 2014 and was thus evaluated during the spring of 2013. This means that the data for government deficit and debt were from 2012 (European Commission, 2013), as mentioned in Box 1.4.3.

Upon entering the Eurozone the first three criteria no longer apply while the latter two do; this formed the original Growth and Stability Pact (TFEU, Article 126). One may argue that all five criteria, in essence, relate to price stability. A country with stable inflation has no need to devalue to maintain a competitive position, a country where financial markets do not expect devaluation will typically be able to borrow at low interest rates and low deficit and debt can be dealt with without relying on monetization and ensuing higher inflation.

Several of the original countries that joined the Eurozone in 1999 did not fulfil all the criteria, especially the debt criterion, which led several scholars to conclude that the original formation of the Eurozone was more based on political aspirations than economic reasons (de Grauwe, 2009). Enlargements of the Eurozone after Greece's accession in 2002 have, however, seen the criteria being applied stringently. As an example, the only incidence of a country seeing its application to join being thwarted was Lithuania in 2006, when it failed to meet the inflation criterion by just 0.1 percentage point (European Commission, 2006). Thus, Latvia was strictly audited to ensure that it met the criteria.

The process of joining the Euro Area began when Latvia joined ERM II in May 2005, opening up for the possibility of adopting the euro by 1 January $2008^{11}$, as was also envisaged in the press release of 21 September 2003, (Bank of Latvia, 2013).

In spring 2007, when assessment could have been made regarding Latvia and its fulfilment or not of the five Maastricht criteria/Convergence criteria, Latvia chose not to seek this possibility since it was at the height of the credit boom preceding the financial crisis, and was clearly unable, by a long way, to meet the inflation criterion. 2012 was set as the next deadline for adopting the euro but in 2011, at the time for potential assessment, Latvia was still in the IMF-EU led rescue programme following the financial crisis ${ }^{12}$, thus also not making euro adoption possible.

The next target was then set for 2014. As countries with a derogation (non-euro countries) are evaluated every two years (TFEU Article 140) by the Commission and the ECB in terms of fulfilment of the Maastricht criteria and 2013 was not such a year, Latvia requested, as was its right, an evaluation in the form a convergence report (EU Commission, 2013).

Assessed in the spring of 2013, Latvia fulfilled all criteria (on inflation, long-term interest rates, fixed exchange rate to EUR without devaluation for at least two years, government budget deficit and government debt) and euro adoption went ahead on 1 January 2014 at the previously mentioned and now irrevocable parity exchange rate of 0.702804 LVL per EUR.

A long information campaign (see the www.eiro.lv web site) took place but also legislation had to be changed or amended and this is, arguably, the area where EU regulation has the most significant impact on Latvian legislation, economically speaking.

Significant changes to the Law on the Bank of Latvia have been made, monetary policy objectives have been somewhat redefined, fiscal policy objectives and the budgeting process as well as dissemination of fiscal statistics have been altered and a new independent institution, the Fiscal Discipline Council had to be created.

Article 14.1 of Protocol No 4 of the TFEU makes it very clear: "In accordance with Article 131 of the Treaty on the Functioning of the European Union, each member state shall ensure that its national legislation, including the statutes of its national central bank, is compatible with these Treaties and this Statute" (TFEU, 2012, Protocol no 4, Article 14). The original law "On the Bank of Latvia" was adopted on 19 May 1992. In early versions, the main goal was described as "an inflation rate as low as possible", which is an unfortunate formulation as it would imply deflation as acceptable. Subsequent versions have seen quite a few amendments (see Law on the Bank of Latvia) and a version prior to the one adopted to fulfil the TFEU Protocol had Latvian monetary policy defined as "controlling the amount of money in circulation with the aim to maintain price stability in the State". With euro adoption the price stability criterion has become more explicit ${ }^{13}$ and is no longer about Latvian inflation.

As mentioned in Box 1.4.3., the deficit and debt criteria remain after euro adoption and at first were meant to be monitored via the original Stability and Growth Pact, as described in Article 126 of the TFEU. In 2012 the Treaty on Stability, Coordination and Governance in the Economic and Monetary Union (the 'Fiscal Compact') added a revised Stability and Growth Pact, allowing member states to have a structural budget deficit ${ }^{14}$ of $0.5 \%$ of $\mathrm{GDP}^{15}$ (Article 3 ).

\footnotetext{
11 Joining ERM II in May 2005 would need until May 2007 to fulfill the criterion of two years without devaluation. Decisions regarding euro adoption are usually taken in the summer of a certain year with de facto euro adoption 1 January the following year, i.e. 1 January 2008.

12 Blanchard, Griffiths and Gruss (2013) provide a detailed account of the Latvian economy before, during and after the financial crisis.

13 The ECB has a very precise definition of price stability, defined as close to but below $2 \%$ inflation in the medium term of the Harmonized Consumer Price Index of the Eurozone countries.

14 I.e. the budget deficit that would prevail if the economy of the members state were at full employment. This term is useful as it eliminates the actual budget balance's dependency on the economic cycle. It is also controversial since it has to be estimated.

${ }_{15}$ Countries with a debt-to-GDP level less than 40\% of GDP are allowed a structural deficit of $1.0 \%$; a position Latvia has taken advantage of on several occasions.
} 


\section{Major changes to the Law on the Bank of Latvia, following euro adoption}

Latvia's Law on the Bank of Latvia was created with the help of Germany's Bundesbank and Latvian monetary policy was already in the 1990s quite "Germanic" with a strong focus on price stability to be achieved by a very independent central bank, a view also promoted by advice from Latvian-American economist Juris Vīksniņš of Georgetown University (Bank of Latvia, 2013, 1). This German view of a central bank also became the focal point when the ECB was created in the late 1990s and as a result, institutionally and in terms of monetary policy, Latvia did not require much change to adopt to its role as part of the European System of Central Banks (ESCB).

The main changes to the Law on the Bank of Latvia are seen in Article 2 that specifically adds that Latvia is a member of ESCB and that the Bank of Latvia therefore shall observe the laws, of the TFEU "as well as other legal acts and instruments regulating the functioning of the national central banks in accordance with the Treaty [TFEU] and Protocol No 4". Article 3 reiterates that the primary objective of the Bank is to maintain price stability and is modified to include that Bank of Latvia "shall support the general economic policies in the European Union in accordance with Article 127(1) of the Treaty [TFEU]". In terms of independence, the important Article 13 of the law, which defines the independence of the institution, is smoothly altered to resemble Article 130 of the TFEU.

In short, the Law is changed to acknowledge that Latvia now, in terms of monetary policy and institutional governance, is an integral part of the ESCB and the laws and statutes governing the ESCB but that the Bank of Latvia otherwise remains a highly independent institution. Independence may even have been enhanced by joining the euro and the ESCB: Latvian authorities, on 19 February 2018, adopted measures to forbid then Bank of Latvia governor, Ilmārs Rimševičs, to act as governor due to alleged corruption, a charge Mr. Rimševičs denies. On 26 February 2019, these measures were overturned by the European Court of Justice, using Article 14.2 of the Statute of the European System of Central Banks (Court of Justice, 2019).

As Figure 1.4.8. reveals, Latvia has not strictly adhered to this provision although breaches since euro adoption have been minor. ${ }^{16}$

From Figure 1.4.9. it can be seen, however, that since 2012, Latvia has been adhering very well to the 'old' Maastricht criteria. During the financial crisis where Latvia broke the deficit criterion, the country became subject to the corrective arm of the Excessive Deficits Procedure of the Stability and Growth Pact (European Commission, Excessive Deficits Procedures) as also described in TFEU Article 126. ${ }^{17}$ In short, the corrective arm of the Excessive Deficits Procedure provides a country with recommendations for a concrete path as well as time frame to correct the excessive deficit and/or debt position.

Latvia's stance, relative to the other EU member states, may also be evaluated from Table 1.4.2. where the deficit and debt positions of the countries are portrayed. Latvia, together with its two other Baltic neighbours are safely inside the $3 \%$ and $60 \%$ boundaries. Rather few countries experienced major deficit problems in 2019 whereas towering government debt remains an issue in much of Southern Europe. It should be mentioned that 2020 will see a dramatic worsening for all countries due to the fiscal impact of Covid-19. A benign position in 2019 should, however, also speak about a country's possibility for a swift return to fiscal stability.

An important question arises in this context: Is Latvia's adherence to the Maastricht criteria a result of a disciplining effect of the Stability and Growth Pact or is it a result of the benign times between 2012 and 2019 where stable growth produced good tax revenue. Or is it a result of a new institution, which Latvia, with euro adoption, had to establish, namely the Fiscal Discipline Council?

EU Directive 2011/85 (European Council, 2011), Articles 5 and 6 , specify that each member state must adopt national fiscal rules in order to comply with TFEU and that independent bodies must be established to monitor compliance with these fiscal rules. As discussed in Jankovics and Sherwood (2017), this is the first mentioning of what is today known as Independent Fiscal Institutions (IFIs), which every euro member state must have and other EU countries may have. Due to fiscal rules being national (i.e. may differ among member states), national IFIs have also become very diverse in terms of mandates, scope and size (Calmfors and Wren-Lewis, 2011). Latvia's IFI, the Fiscal Discipline Council (FDC),

\footnotetext{
${ }^{16}$ It should also be mentioned that Latvia requested - and received EU permission for - a higher structural deficit as part of the structural reform of the health sector.

17 Latvia will break the deficit criterion by a large margin in 2020 due to Covid-19 and its lockdown effects on many parts of the economy. This is, however, allowed given 'exceptional circumstances' as defined in Article 3C of the Fiscal Compact.
} 


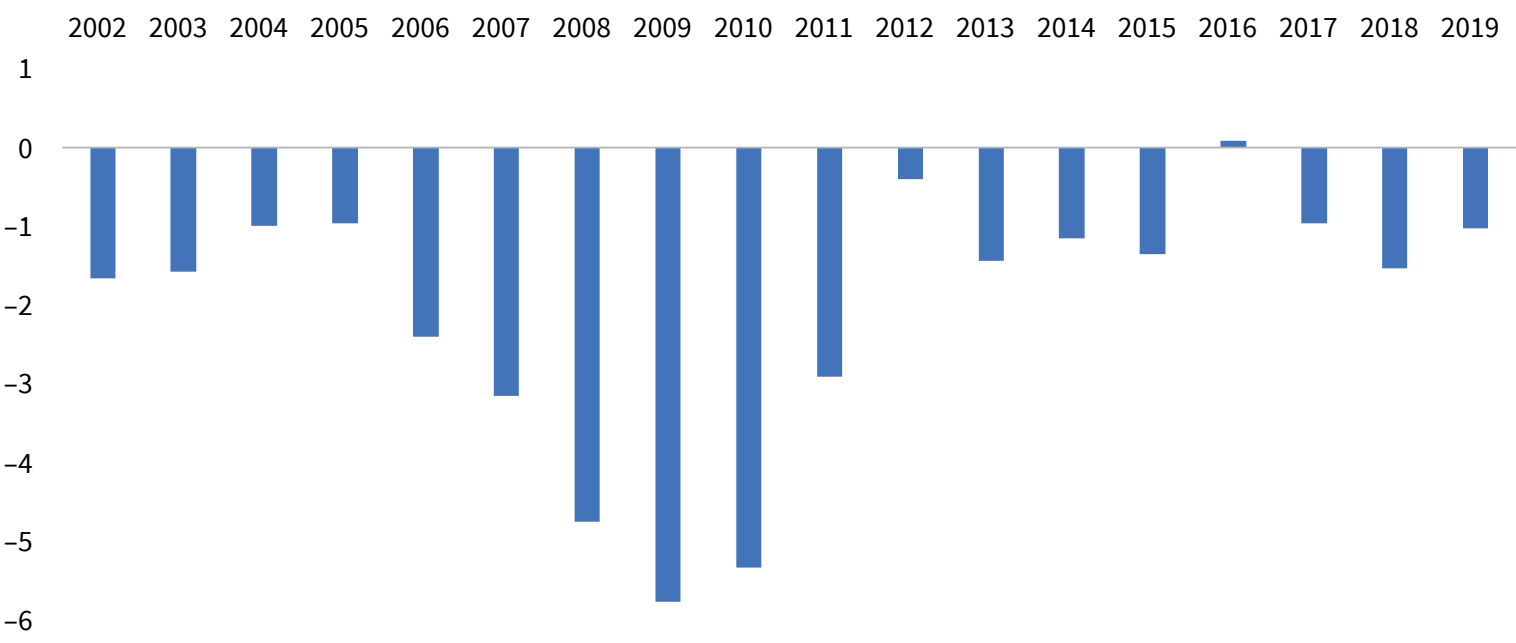

Source: IMF (2020).

Figure 1.4.9. Latvia's government budget balance and gross government debt, \% of GDP, 2000-2019. Budget balance on the first axis, debt on the second axis

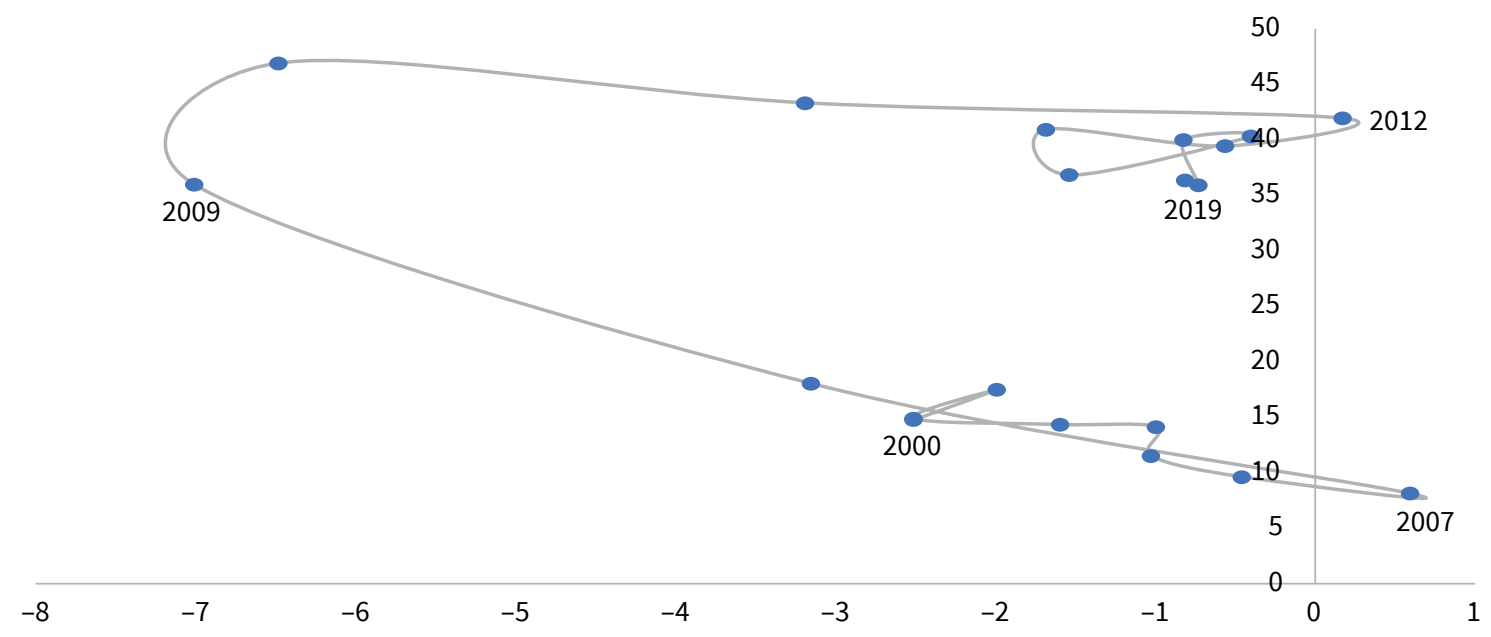

Source: Eurostat (2020).

\section{Table 1.4.2. EU28 and the Maastricht criteria, 2019}

\begin{tabular}{|c|c|c|c|c|c|c|c|}
\hline \multirow[t]{2}{*}{ Debt, $\%$ of GDP } & \multicolumn{7}{|c|}{ Government budget balance, $\%$ of GDP } \\
\hline & $>+2 \%$ & ] $0,+2]$ & ]$-1,0]$ & ]$-2,-1]$ & ]$-3,-2]$ & ]$-4,-3]$ & ]$-5,-4]$ \\
\hline $0-20 \%$ & & & $\mathrm{EE}$ & & & & \\
\hline $21-40 \%$ & BG, DK, LU & CZ, LT, SE & LV & & & & RO \\
\hline $41-60 \%$ & & $\begin{array}{c}\text { DE, IE, MT, } \\
\mathrm{NL}\end{array}$ & $\mathrm{PL}$ & $\mathrm{FI}, \mathrm{SK}$ & & & \\
\hline $61-90 \%$ & & AT, HR, SI & & $\mathrm{BE}$ & HU & ES, FR, UK & \\
\hline $91-120 \%$ & & CY, PT & & & & & \\
\hline $121-150 \%$ & & & & IT & & & \\
\hline $151+\%$ & & EL & & & & & \\
\hline
\end{tabular}

Source: Eurostat (2020). 


\section{Figure 1.4.10. Debt-to-GDP, 2019, EU28. Corona bond countries in dark blue, New Hanseatic League countries in blue}

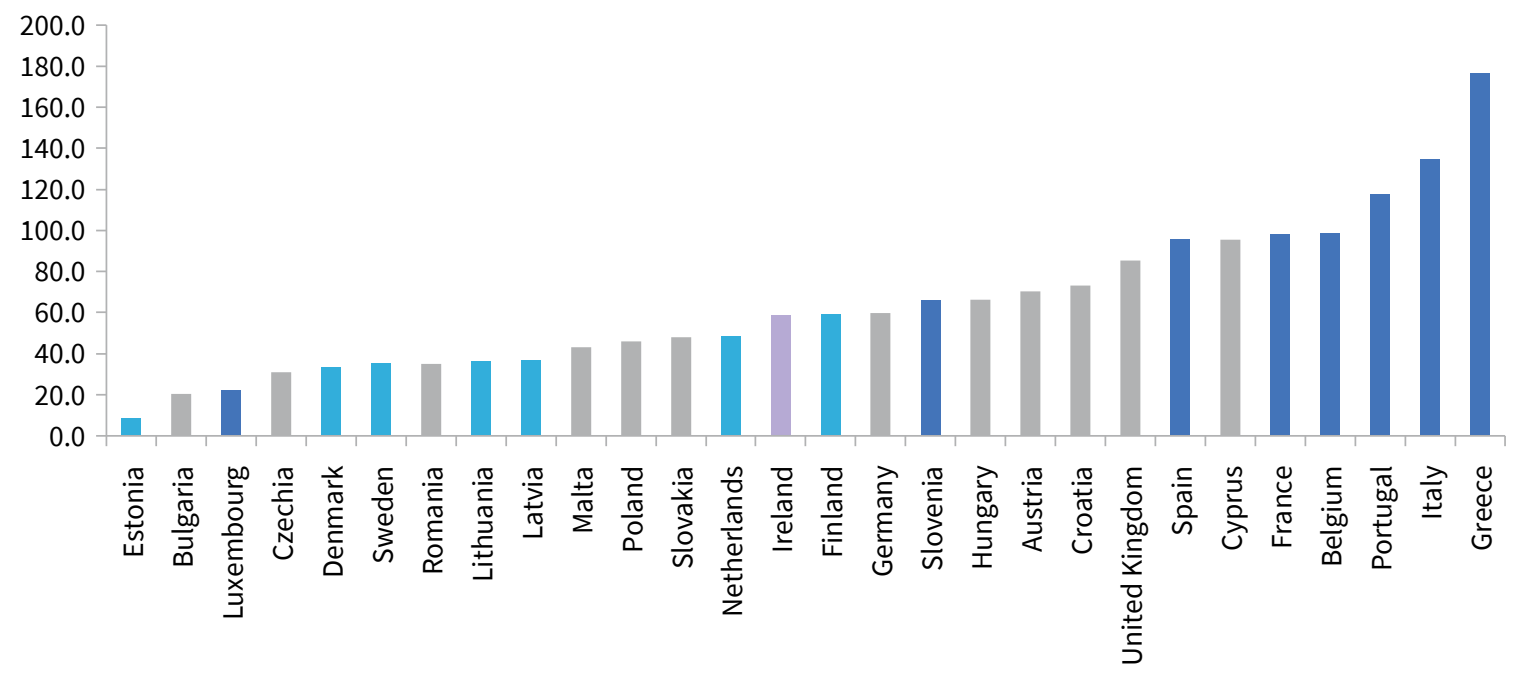

Source: Eurostat (2020).

Note: Ireland (in yellow) is the only country belonging to both groups.

established 1 January 2014, is among the smaller institutions with a six-person council with the mandate to see fiscal policy adhere to the Latvian Fiscal Discipline Law ${ }^{18}$ (FDL), (Fiscal Discipline Council, 2014).

A precise answer to the aforementioned question of whether the Stability and Growth Pact, the benign times between 2012 and 2019 or the FDC have disciplined fiscal outcomes is most likely too early to provide. Some combination seems a good, if vague, first answer. ${ }^{19}$

Complementing the Stability and Growth Pact, the Fiscal Compact and the IFIs are the 6-pack and 2-pack regulations and a slightly provocative conclusion might be that EU regulation surrounding fiscal policy - deficit and debt criteria, budget planning, monitoring etc. - has changed Latvian legislation more than monetary policy due to membership of the Eurozone or trade policy due to membership of the Union.

A final discussion point might be Latvia's role in the politics of the economics of the EU. On 25 March 2020 the leaders of nine Eurozone countries (Belgium, France, Greece, Ireland, Italy, Luxembourg, Portugal, Slovenia, Spain) wrote a letter to Charles Michel, President of the European Council (Letter to Charles Michel, 2020), urging him to promote a debt mutualization instrument (dubbed "corona bonds") in order to give countries access to financing at very low interest rates. Latvia was not one of the signatories and has instead joined the loose network of the so-called 'New Hanseatic

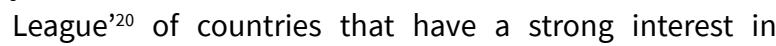
protecting the Single Market and a conservative view of fiscal policy, putting it in opposition to the signatories of the letter to Charles Michel. An instructive way of seeing the difference between these two groups is a look at their debt positions, see Figure 1.4.10.

Adhering quite strictly to EU rules and regulations and forming a somewhat hawkish view on fiscal policy and the Eurozone - a play-by-the-rules attitude - should help Latvia, also in the aftermath of Covid-19. Add to this that the country scores quite well (although not brilliantly and typically behind Estonia and Lithuania but usually better than most of Southern Europe) in terms of structural indicators, be they from Transparency International (corruption perception), World Bank (Ease of Doing Business) or World Economic Forum (competitiveness), and future economic development should be looked upon with optimism. Being part of the New Hanseatic League reveals Latvia as one of the more hawkish nations in terms of fiscal policy in the EU but otherwise, in economics terms, the country remains rather anonymous within the EU.

\footnotetext{
18 The Law specifies fiscal policy principles, planning, surveillance and defines the fiscal targets that must be complied with, e.g. a structural balance permitting a maximum of a $0.5 \%$ of GDP deficit.

19 Fiscal policy requiring, due to the Treaty and due to the FDL, a three-year planning horizon seems to help provide fiscal discipline.

20 Members are Denmark, Estonia, Finland, Ireland, Latvia, Lithuania, Netherlands and Sweden.
} 


\section{Main conclusions}

Membership of the European Union in 2004 and of the Eurozone in 2014 has done much to change the Latvian economy. It outperforms the CIS countries in terms of GDP per capita but lags behind, and always has, Estonia and Lithuania. Whereas EU membership dates back to 2004, trade and FDI integration with the old EU-15 dates back to the 1990s; EU membership and thus becoming part of the EU's Single Market facilitated trade and investment relations with other new member states such as Estonia, Lithuania and Poland. It is incorrect to say that this development was easy but, with hindsight, it seems rather seamless. Latvia transformed fairly easily into a full-fledged market economy and is today deeply integrated with the rest of the EU in terms of trade and foreign investment - though the Russian Federation still plays a major role in terms of the latter and less in terms of the former.

As a small, open economy Latvia is also a natural candidate for the Eurozone's single currency. With an already 'German' law for its central bank (i.e. an overriding objective to provide price stability by a strongly independent central bank) it was arguably easy to transform the Latvian central bank law into one that adheres to the TFEU as Bank of Latvia has become a member of the European System of Central Banks.

More - and deeper - legislative change has been adopted in terms of accompanying fiscal policy. Adhering to the Stability and Growth Pact, the 'Fiscal Compact', the 6-pack and the 2-pack has transformed the fiscal policy process in Latvia, made budgeting more forward-looking and given the EU a much stronger role in terms of Latvian fiscal policy. Following the fiscal mismanagement before the financial crisis, this is a most welcome step.

\section{Main tasks}

The major economic-policy issue for Latvia is also related to the EU but not to EU legislation per se. Although having achieved significant partial economic convergence with its EU peers, economic convergence is exactly just that: Partial. At $69 \%$ of the EU28 average in terms of GDP per capita in 2018, ahead of Romania, Greece, Croatia and Bulgaria, Latvia is still one of the poorer member states of the EU, a position that over the years, in a community with free movement of labour, has led to significant outward migration, a development which via brain-drain hampers full economic convergence and which, with a smaller labour force, puts a strain on future tax revenue and thus future government spending capacity.

In terms of international institutional developments - EU membership, part of the Eurozone, member of the OECD etc., Latvia has done its homework to prepare for future economic convergence. What remains is almost entirely national such as education reform, judicial reform, the continued fight against corruption and the grey economy. Issues that have been on the table for many years and where progress has been made but where work still remains to be done. 


\subsection{The Satversme, the Constitutional Court and the European Union}

\section{Jānis Pleps}

Pursuant to amendments of 8 May 2003 to the Satversme (the Constitution of the Republic of Latvia, hereinafter - the Satversme), a decision on Latvia's membership in the European Union (EU) must be made via a referendum. On 20 September 2003, the totality of Latvia's citizens supported Latvia's accession to the EU in a referendum (CEC, 2003). The people's vote of 20 September 2003 ensured the constitutionally required democratic legitimation to Latvia's membership in the EU and allowed Latvia to accede to the EU as a Member State on 1 May 2004.

The EU is a unique and complex mechanism for European integration aimed at ensuring lasting peace on the continent of Europe and close economic integration of its Member States (Dedman, 2010). Common achievements in this process of integration in promoting peace, reconciliation, democracy and human rights have been appreciated by the award of the Nobel Peace Prize (Van Rompuy, Barroso, 2012). Notwithstanding the obvious achievements, European integration is a constant challenge for the readiness of its Member States and citizens to maintain the idea of European unity and, in the name of that unity, accept that a somewhat extensive range of issues is left for common decisions in the interests of all Member States. The European integration project has never been a fully elaborated model; indeed, that was never the objective of its creators (Schuman, 1950). The historical development of the EU reveals openness to new and closer forms of integration as well as respect for the sovereignty and constitutional legacy of the Member States.

Europeanization and maximal harmonisation of the Member States' legal systems is one of the main mechanisms for attaining the aims of the EU and for its effectiveness. To ensure close economic integration and free movement of goods, services, capital and persons, requires a harmonised legal system following the same principles. EU law must be applied similarly in all Member States and, in all instances of application, must reach the same aims that necessitated it. Moreover, effective mechanisms are needed, capable of ensuring effective and uniform application of EU law, turning the Member States into a unified legal space.

The effectiveness of EU law in the legal systems of the Member States and thus also the effectiveness of the EU itself is ensured by the primacy of EU law over national legal norms so that, in cases of potential collision, the matter would always be resolved in compliance with EU law (ECJ, 1964; ECJ, 1978). The Member States and their legal systems must reckon with the principles of the direct effect and primacy of EU law as well as the fundamental role of the Court of Justice of the European Union (CJEU) in the legal system of the European Union (Raihs et al., 2004, 39-42; Tamm, 2013).

Membership in the EU demands close harmonization of the Member States' national legal systems and ability to ensure application of EU law in compliance with the required standards and methodology. Membership in the $\mathrm{EU}$ is a kind of assessment of the readiness and successfulness of a legal system (Levits, 2018b, 58). If a legal system has problems with ensuring the principles of a state governed by the rule of law, independence of the judicial power and methodology for applying legal norms as appropriate for a democratic state governed by the rule of law, this causes risks for the common effectiveness of the EU and makes the presence of that legal system in unified European legal space difficult (Sadurski, 2019, 199-202, 227-232; CJEU, 2018).

Following restoration of Latvia's independence, membership in the EU became a strategic aim, and achieving it required radical and irreversible Europeanization of the legal system. The ambition to become a Member State of the EU served as "the push" for the required reforms in the area of justice, and the EU has facilitated restoration of a legal system of a democratic state governed by the rule of law, complying with the traditions and standards of continental Europe (Buka, 2017).

This chapter aims to characterise the principles of Europeanization of Latvia's legal system as manifest in legal reality. To achieve that aim, the need for the Europeanization of Latvia's legal system as well as constitutional principles regarding membership in the EU will be characterised. In addition, the case law of the Latvian Constitutional Court in matters of EU law as well as potential challenges within legal reality will be examined.

In analysing these issues, focus will mainly be put on the case law of the Constitutional Court and its approach to the Europeanization of the legal system, since the Constitutional Court is the leading driving force in development of the Latvian legal system. The Satversme grants the Constitutional Court the right to 
review compliance of laws and other regulatory enactments with the Satversme. Likewise, interpretation of the Satversme by the Constitutional Court and its stance on relevant matters of law are legally binding on others. In the context of Europeanization of the legal system, protection of Latvia's sovereignty and constitutional identity falls within the Constitutional Court's competence (Ziemele, 2020). Similarly to other countries, in Latvia, too, the attitude towards the EU and legal reality is revealed by the case law of the constitutional court. It is important to underscore that the Latvian Constitutional Court could be recognised as being one of the EU law-friendliest European constitutional courts. This, to a large extent, has facilitated the openness of the Latvian legal system towards EU law and Eurooptimism (Pleps, Plepa, 2016, 25-26).

\section{The need for Europeanization of the legal system}

Historically, the Latvian legal system has developed within and as part of the legal family of continental Europe. Belonging to the same legal family means more or less the same understanding of law and methodology of applying the law as well as shared philosophical and constitutional foundations of the legal system. The Soviet occupation interrupted the development of the Latvian legal system within the common tradition of continental European law and for fifty years imposed a system that was based on utterly different aims and principles, incompatible with the tradition of continental European law (Levits, 1999, 6-10). The Soviet (or, more broadly, socialist) legal system aimed at consistent annihilation of the former legal heritage and its transformation for the ideological and practical needs of the occupation regime of the existing totalitarian state (Kühn, 2004, 538-549).

Following restoration of independence, ever-deeper integration into Euro-Atlantic structures, for example by acceding to the EU (at that time still the European Communities), turned into one of Latvia's long-term strategic aims. Membership in the EU was also seen as one of the safeguards for Latvia's independence and security (Jundzis, 2001, 124-126). Symbolically, accession to the EU served as testimony of Latvia's full return to Europe, whereas in practice it was an effective instrument for the long-term development and alignment of the state as well as ensuring geopolitical extrication from the potentially unclear location within Russia's sphere of influence (Taurēns, Feldmanis, 2016, 94-95). Once independence had been restored, it was important for Latvia to protect itself as well as it could against the possibility of history repeating itself, in particular taking into account the deeply complicated neighbourly relationship with Russia. For a rather long period following restoration of independence, a comparatively stable choice existed in Latvian society regarding national development - either in the direction of the Western democracies or a potential return to Russia's sphere of influence (Levits, 2018a, 392). At the same time, for its long-term existence as an independent democratic state, Latvia had no alternative but a united Europe and Latvia's irreversible involvement in processes of European integration (Levits, 2018a, 532).

The restoration of Latvia's independence required rapid and radical transformation of the legal system, entirely abandoning the system imposed by the occupation regime and returning to the legal family of continental Europe. The Latvian legal system had to regain an understanding of law and the philosophical and constitutional foundations as well as the methodology for applying the law typical of the continental European legal tradition. Transformation of the legal system has turned out to be a lengthy and complicated process since some elements of the Soviet occupation regime are quite viable in the new circumstances (Levits, 2018b).

The process of transforming the Latvian legal system coincided with Latvia's integration in the EU. Thus the legal system was transformed not only

Box 1.5.1.

\section{Elements of the Soviet occupation regime discernible in the Latvian legal system}

- Legal nihilism

- Formal application of law

- Abuse of law

- Non-compliance with or evading the law

- Failure to enforce the law

- Insufficient Europeanization of legal education

- Deformation of legal awareness and legal culture in society, in particular among lawyers

Source: Levits, 2018b, 57-59; Levits, 2020a. See also: Kühn, 2004. 
as a democratic state governed by the rule of law belonging to the legal family of continental European law but potentially also as the legal system of a Member State of the EU (Levits, 2018b, 57). This called for substantial changes in almost every area of the legal system as well as professional growth and re-learning the fundamental principles of the legal system for key figures within the legal system (Harbaceviča, 2016). In conditions of transformation, legal education and professional experience from the period of the Soviet occupation regime was insufficient. The Justices of the Constitutional Court at the time made a far-reaching conclusion, namely that full membership in the EU required not only technical harmonisation of Latvia's own regulatory enactments with the texts of EU law but also adoption of Western legal theory and legal thinking, so that a uniform understanding of law would develop in the vein of the traditions of European legal culture (Endzinš̌ et al., 2000). Therefore Latvia's membership in the EU created an obligation for all those involved in the functioning of the legal system to adapt to changes and to acquire new knowledge and skills (Constitutional Court, 2007).

A convincing consensus on the need for a return to the legal tradition of continental Europe as well as strong support for membership in the EU and Europeanization of the legal system has always existed in the Latvian legal system. Within that system, becoming a Member State of the EU was generally accepted as the main attainable goal following restoration of independence by promoting large-scale transformation of the legal system from that of the period of Soviet occupation to that of a democratic state governed by the rule of law belonging to the continental European law family (Levits, 1999, 11). The opinion of Eurosceptics - those objecting as a matter of principle against membership in the EU - has never gained noteworthy impact in Latvian legal policy, science, or practice of law. To a large extent, this has been determined by the geopolitical context and the context of negative historical experience. Latvia's successful integration in the EU and Europeanization of the legal system was perceived as an effective safeguard for the existence of an independent Latvian state and a possibility to prevent history from repeating itself.

Thus, to a large extent, the openness and Eurooptimism of the Latvian legal system has been coercively determined by legal policy. However, the Latvian legal system has been able to manage its risks and potential impacts meaningfully and, accordingly, to restore a successful and developed democratic state governed by the rule of law. Membership in the EU is indirect evidence of the stability and success of Latvian democracy; however, this does not diminish the obligation of constant care for consolidation of a democratic state governed by the rule of law and protection of democratic values in the future as well (Constitutional Court, 2018d).

\section{Constitutional foundations for Latvia's membership in the EU}

The values most relevant for each legal system find their most vivid manifestation in the text of the constitution. Sometimes, even unconsciously, the constitutional text reiterates, as frequently as possible, the values that the particular legal system would never want to lose, while repeated amendments are often introduced to protect those values (Sajó, 1999, 5-9). In the case of Latvia, it is significant that alongside the independent state, personal freedom and the Latvian language, belonging to a united Europe is also clearly outlined in the text of the Satversme as an equal value (Pleps, 2018 , 104). Although there may be enough scepticism and doubt in the legal system regarding the need for Europeanization, nevertheless the lack of a genuine geopolitical alternative excluded the possibility to develop Euroscepticism or collisions with EU law. Indeed, it could be concluded that belonging to a united Europe is part of the Latvian constitutional identity as one of the elements that characterise the state of Latvia and its legal system. Following from this is the openness of the Latvian legal system to a unified European legal space and participation in European integration as well as the obligation to maintain and promote this element of constitutional identity in legal reality.

It is customary in constitutional law to examine constitutional identity as a totality of inviolable values characterising the legal system of the particular state. In the "old" Member States, the concept of constitutional identity was developed to protect the national legal system from external interference, which could be implemented ultra vires by the EU (Osipova, 2018). Protection of constitutional identity has served as an argument in the Member States' caution vis-à-vis the EU and reservations on the part of their constitutional courts regarding the need to verify the extent to which EU law does not infringe on a Member State's constitutional identity (Besselink, 2010). For Latvia, defining constitutional identity has been related to efforts at self-protection as a democratic state governed by the rule of law from internal threats, reinforcing the state as a self-defensive democracy (Osipova, 2018). In this context, it is not surprising that belonging to a united Europe is one of the values characterising Latvia's constitutional identity. Membership in the EU does not jeopardise Latvia's constitutional identity and is not contrary to or in collision with it - involvement in development of the EU characterises Latvia's constitutional identity. By raising awareness of Latvia's constitutional identity in the Latvian legal system, belonging to a united Europe and membership in the EU should be integrated in a more targeted way into the constitutional identity rather than being intentionally separated from or contrasted to other elements of constitutional identity (Ziemele, 2018). 
Belonging to a united Europe as an element of constitutional identity has defined the geopolitical orientation of the Latvian legal system. In legal policy terms, the Latvian legal system is characterised by openness and readiness to participate in processes of European integration and be part of the unified legal space of the EU. Closely related to this is isolation from the sphere of Russia's influence and a somewhat cautious attitude towards Russia, as defined in Paragraph 9 of the Declaration of 4 May 1990 "On Restoring the Independence of the Republic of Latvia". Pursuant to this norm, any relations with Russia must be developed only on the basis of the Peace Treaty of 11 August 1920, which recognized the independence of the Latvian State in perpetuity (Levits, 2020b). In addition, the Latvian Satversme excludes membership in organisations that are not aimed at strengthening democracy or, quite the contrary, promote the development and reinforcement of non-democratic regimes, undermining the values of a democratic state governed by the rule of law (Rodina, Pleps, 2013, 442).

In processes for EU enlargement, a certain standard has evolved regarding accession of a new Member State to the EU (Albi, 2005). Firstly, it is expected that the citizens of that state will decide on membership in the EU in a referendum. Secondly, membership in the EU requires amendments to the constitution that would define clear and predictable conditions of the state's membership in the EU (Levits, 2000). In effect, such amendments open the national legal system constitutionally for integration in the EU and include in the constitution the regulation needed for the effectiveness of EU law (Ziemele, 2020, 12-14).

Pursuant to the founding treaties of the EU, a state's membership in the EU is linked to partial transfer of national competence to the $\mathrm{EU}$ and restrictions on the state's discretion. Looking at it from the perspective of the national legal system, these issues can be resolved by appropriate alignment in the framework of the constitution (Ziemele, 2004, 68-70). If the constitution does not resolve matters of membership in the EU, the risks of regular conflict between the constitution and EU law are high. Amendments to the constitution allow the necessary constitutionalising of the EU within the national legal system and for the constitution to recognise the effect of EU law, defining the applicable legal norms.

\section{Box 1.5.2.}

\section{Amendments of 8 May 2003 to the Satversme with respect to Latvia's membership in the EU}

1. To express Article 68 in the following wording:

"68. All international agreements which settle matters that may be decided by the legislative process shall require ratification by the Saeima.

Upon entering into international agreements, Latvia, with the purpose of strengthening democracy, may delegate a part of its State institution competencies to international institutions. The Saeima may ratify international agreements in which a part of State institution competencies are delegated to international institutions in sittings in which at least two-thirds of the members of the Saeima participate, and a two-thirds majority vote of the members present is necessary for ratification.

Membership of Latvia in the European Union shall be decided by a national referendum, which is proposed by the Saeima.

Substantial changes in the terms regarding the membership of Latvia in the European Union shall be decided by a national referendum if such referendum is requested by at least one-half of the members of the Saeima.

2. To express Article 79 in the following wording:

"79. An amendment to the Constitution submitted for national referendum shall be deemed adopted if at least half of the electorate has voted in favour.

A draft law, decision regarding membership of Latvia in the European Union or substantial changes in the terms regarding such membership submitted for national referendum shall be deemed adopted if the number of voters is at least half of the number of electors as participated in the previous Saeima election and if the majority has voted in favour of the draft law, membership of Latvia in the European Union or substantial changes in the terms regarding such membership." 
In the Satversme, matters concerning membership in the EU were basically resolved by amendments of 8 May 2003 (Krūma, Statkus, 2019, 954-958). The need to amend the Satversme was identified relatively early and received considerable attention (Lejnieks et al., 2019, 95-96). Within the Latvian legal system, experts extensively discussed the possible amendments and, as a result, well-considered and sustainable regulation was prepared. Drafting of the amendments to the Satversme respected its laconic and concise style, so that the amendments to ensure membership in the $\mathrm{EU}$ are minimal (Albi, 2005, 94-98). At the same time, they are not excessively detailed and technical; rather, the most essential principles for Latvia's membership in the EU are defined (Levits, 2007, 584-586). These amendments have turned out to be sufficient for the Constitutional Court to successfully develop principles in its case law accordingly and to elaborate them in legal reality (Krūma, Statkus, 2019, 959-960).

It is important to underscore that the Satversme defines the conditions and the procedure for membership in the EU, giving the possibility to decide on the matter to the Saeima and the totality of citizens (Working group, 2001). The amendments introduced in the Satversme the principle of European integration that had to be taken into account in interpreting and applying the Satversme (Balodis, 2004, 16-17). Actually, in this way Latvia's legal policy decision to be a Member State of the EU, to be implemented in compliance with the founding treaties of the $\mathrm{EU}$, is defined in the Satversme.

Article 68 of the Satversme is the constitutional basis for interaction between the national legal system and EU law. The required conditions for the effect of EU Law within the Latvian legal system must be derived from Article 68 of the Satversme (Constitutional Court, 2018c).

The constitutional solution of the Satversme for Latvia's membership in the EU is defined as implementation of the sovereignty of the state and the people, delegating some national competences to the EU, rather than restricting or delegating sovereignty as such (Endziňš, 2003). Pursuant to Article 68 of the Satversme, Latvia transfers to the EU only some national competences, pursuant to the founding treaties of the EU, without affecting or diminishing its sovereignty. This was a decision of prime importance, which allowed no amendment to Articles 1 and 2 of the Satversme, admitting comparatively lower requirements with respect to the quorum and the majority vote in a referendum on membership in the EU. This also ensures the constitutional framework for membership in the EU, that is, membership is possible while retaining the independence of the state of Latvia and the people's right to decide at any moment on continuing membership in the EU. In effect, this constitutionally guarantees the inviolable existence of the state of Latvia and the people's sovereignty.
It is important for Latvia that membership in the EU does not affect national independence and the sovereignty of the people and also that the totality of Latvia's citizens can, as envisaged in the Satversme, decide on discontinuing membership in the EU (Constitutional Court, 2009a). If processes of European integration were to jeopardise national independence and the people's sovereignty, they would be constitutionally inadmissible. Thus the Satversme sets a substantive restriction on Latvia's membership in the EU (Ziemele, 2020, 14-15).

The Satversme sets out the substantive conditions for Latvia's membership in the EU, in that it is admissible only with the purpose of strengthening democracy. So long as membership in the EU does not pose a threat to the order of a democratic state governed by the rule of law in Latvia, it is to be fostered in legal policy and is constitutionally admissible. The constitutional bodies defined in the Satversme have the obligation to verify constantly whether that condition is met (Ziemele, $2020,19)$. This is an essential condition, viewing Latvia's membership in the EU as one more element reinforcing Latvia as an independent democratic state governed by the rule of law. Membership in the EU should aim at irreversibly strengthening the order of a democratic state governed by the rule of law in Latvia and must serve as (one more) supranational safeguard for the protection of a democratic state governed by the rule of law (Ziemele, 12-13).

The duty to maintain the national legal system as a democratic state governed by the rule of law also follows from the Satversme. The Constitutional Court has recognised that "norms of EU law are compatible only with a national legal system that complies with the requirements of a democratic state governed by the rule of law" (Constitutional Court, 2003b).

The EU should be able to protect the order of a democratic state governed by the rule of law of a Member State even against the Member State itself if the processes developing in it are basically aimed at dismantling a democratic rule-of-law state. So long as a Member State wishes to retain its membership in the EU it should be able to ensure full functioning of the order of a democratic state governed by the rule of law within its legal system. Protection of the order of a democratic state governed by the rule of law is not only the responsibility of a single Member State but also the shared responsibility of the other Member States and the EU as a whole.

The Satversme provides that only the totality of citizens may decide on membership in the EU in a referendum. Both Latvia's accession to - and possible secession from - the EU are solely in the competence of the totality of Latvia's citizens: other constitutional bodies may not decide on this. It is important for the Latvian legal system that Latvia has retained "the right to the final say" and the totality of Latvia's 
citizens have the competence to decide on secession from the EU (Constitutional Court, 2009a).

Pursuant to the second part of Article 68 of the Satversme, accession to the EU as well as further international treaties that develop the EU and pertain to transfer of national competences to the EU must be approved by the Saeima with a constitutional majority. Thus, the Saeima's approval of such an EU integration measure happens by an act of constitutional level with the same legal force as the norms of the Satversme (Constitutional Court, 2009a). The very form of deciding on EU-related matters determines that these are relevant, constitutional-level matters for the Latvian legal system. This demands cooperation between the majority and the minority in the Saeima for deciding on membership in the EU because, most often, the constitutional majority required in the Satversme cannot be ensured without involving the opposition.

Article 68 of the Satversme allows a referendum both with respect to Latvia's secession from the EU and to significant changes to the terms of membership. Through this, the Satversme comprises a guarantee of the final say by Latvia's people and which provides the possibility to discontinue membership in the EU if at some point the EU no longer complies with Latvia's national interests (Constitutional Court, 2009a). Likewise, the will of the totality of Latvia's citizens may be clarified if the form of European integration changes significantly and Latvia's constitutional identity is affected (Lejnieks et al., 2019, 126-127).

The Satversme defines the constitutional foundations for Latvia's membership in the EU and the principles that must be complied with in developing the relationship between the national legal system and EU law. By recognising Latvia's membership in the EU, the Satversme also recognises the legal principles that ensure implementation of EU law, including the principle of direct effect and the primacy of EU law.

By amendments to the Satversme of 19 June 2014, the geopolitical orientation of the Latvian legal system is reinforced in the sixth paragraph of the Preamble to the Satversme, which envisages Latvia as an equal member in the project of a united Europe, aware of its obligation to promote the sustainable and democratic development of a united Europe (Balodis, 2014, 134). It must be noted that the legislator has purposefully included a reference to a united Europe rather than to the EU, being aware that the process of European integration is in constant development and that potentially new forms of the idea of a united Europe might appear that could be implemented in the future. The wording allows forms of potentially closer integration compared to the EU in its current manifestation, so long as they respect the substantive restrictions set in the Satversme for Latvia's participation in the process of European integration.

\section{The Constitutional Court and Europeanization of the legal system}

Quite frequently, the CJEU has been called the driving force for European integration in that, through its judgments, it has been consistently developing EU law and ensures its primacy and direct effect throughout the space where EU law applies (Kelemen, Schmidt, 2012). In contrast, the constitutional courts of the EU Member States have been characterised by a somewhat reserved attitude towards EU law and the role of hindering the processes of European integration because constitutional courts basically focus on protecting the supremacy of the constitution of an individual Member State and its constitutional identity vis-à-vis EU law (Claes, Reestman, 2015). To a large extent, this interaction between the CJEU and the national constitutional courts has been determined by one of the intellectually leading courts of Europe the Federal Constitutional Court of Germany, which traditionally has been somewhat sceptical towards the processes of European integration (Sadurski, 2012, 99-100; Kucina, 2020, 9-10). The openness of the legal system of a Member State to EU law or, to the contrary, caution or scepticism towards it, to a large extent depends on the position taken by the constitutional court of the respective EU Member State towards EU law and the CJEU.

The Latvian Constitutional Court is one of the EU law-friendliest constitutional courts and the one most open to European integration. Due to some of the arguments used, the Latvian Constitutional Court has sometimes been seen as a "soft version" of the position taken by the Federal Constitutional Court of Germany, at the same time recognising its generally friendly attitude towards Europe (Sadurski, 2012, 106). However, this is a rather simplistic view because the Constitutional Court's position towards Europeanization of the legal system is much more nuanced and reveals much greater trust in the CJEU and openness to EU law (Claes, Reestman, 2015, 944). It is worth noting that the Latvian Constitutional Court in its case law has purposefully adopted a position contrary to that taken by the Federal Constitutional Court of Germany (Krūma, Statkus, 2019, 962).

From the perspective of legal policy, the Constitutional Court's view on Europeanization of the legal system was determined by the self-identification of the first President of the Constitutional Court Aivars Endziņš as a Eurooptimist (Endziņš, 2004, 2). Even during the process of acceding to the EU, the Constitutional Court emphasised that Latvia's legal regulation had to be harmonised with EU law (Constitutional Court, 2002). The Constitutional Court considered harmonisation of national legal norms with EU law to be a vital legal policy objective, being aware of the obligation of the Latvian legal system to ensure effective implementation of EU 


\section{The most relevant judgments of the Constitutional Court with respect to Latvia's membership in the EU}

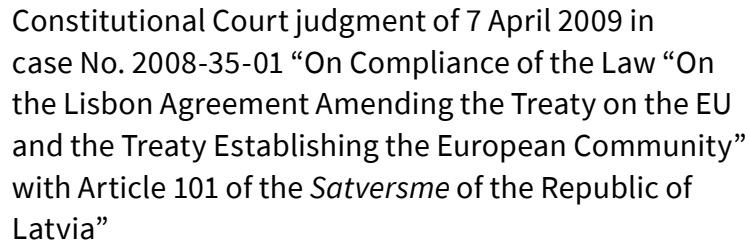

In this judgment, the Constitutional Court reviewed the terms of Latvia's membership in the EU, defined the maximum limits so far as, pursuant to the Satversme, Latvia's membership in the EU was admissible, and also interpreted the norms of Article 68 of the Satversme

In this judgment, the Constitutional Court characterised EU law as an integral part of the Latvian legal system and envisaged interpretation of Latvian legal norms in accordance with EU law

The first judgment by the Constitutional Court following Latvia's accession to the EU, underscoring the obligation to ensure that commitments following from membership in the EU were duly met

In this judgment, the Constitutional Court defined the Satversme's openness to EU law, envisaging that, in interpreting the norms of the Satversme, the commitments following from membership in the EU also had to be taken into account

In this judgment, the Constitutional Court set out the legislator's obligation to review, in the legislative process, compliance of draft regulation with EU law as well as to ensure drafting of regulation that reinforced democracy and was sustainable. Ignoring EU law may be a substantial violation of the legislative process

Source: All judgments of the Constitutional Court are available on the Court's homepage (www.satv.tiesa.gov.lv) and are also published in the official journal Latvijas Vēstnesis (www.vestnesis.lv) and are available in the Latvian portal of legal acts www.likumi.lv.

law following accession to the EU (Constitutional Court, 2003a).

Since Latvia's accession to the EU, the Constitutional Court has consistently underscored the need to ensure due fulfilment in the legal system of commitments following from membership in the EU as well as to ensure that EU law was implemented in the process of applying legal norms (Constitutional Court, 2004, 2018a). The Constitutional Court has formulated the openness of the national legal system to EU law and also the obligation to interpret and apply national legal norms in compliance with EU law (Rezevska, Ziemele, 2013,
236-237; Constitutional Court, 2017b). This applies even to establishing the content of the Satversme's norms, in the interpretation of which Latvia's commitments, as a Member State of the EU, must be taken into account (Constitutional Court, 2006).

The Constitutional Court has declared that, pursuant to the Satversme, to reinforce democracy, EU law must be taken into account both in applying and interpreting national normative acts and in eliminating possible contradictions between Latvian and EU law. The Constitutional Court has underscored, in particular, that parties applying a legal norm must take all actions 
falling within their competence to ensure the effectiveness of EU law and reach a solution that would comply with the purpose of EU law (Constitutional Court, 2019d).

The Constitutional Court's conceptual position, which formulates the openness of the entire Latvian legal system to Europeanization, is characterised by two principal findings. Firstly, "with the ratification of the Treaty on Latvia's accession to the EU, EU law has become an integral part of Latvian law. Therefore, the legal acts of EU law and their interpretation, consolidated in the jurisprudence of the CJEU, must be taken into account in application of national regulatory enactments" (Constitutional Court, 2008, 2011). Secondly, "Latvian legal acts are to be interpreted so as to avoid incompatibilities with Latvia's commitments vis-à-vis the EU, unless this affects the fundamental principles included in the Satversme" (Constitutional Court, 2008, 2011).

In this context, the interaction between the primacy of EU law and the supremacy of the constitution is an important matter, as well as setting the priority among these regulations in the case of a potential conflict. In this regard, the Constitutional Court has chosen a Eurooptimistic approach, avoiding or reducing the possibilities of conflict to a minimum as well as formulating the requirements of striving to ensure harmony and compatibility with EU law in applying the Satversme. The Constitutional Court has noted that "coordinated legal norms should exist in the state as function harmoniously within the framework of a unified legal system. This equally applies to compliance of the legal norms of Latvia as a Member State of the EU with EU law, which is part of Latvian law" (Constitutional Court, 2018b).

The Constitutional Court has made a derogation only with respect to a potential collision of EU law with those fundamental principles of the Satversme that constitute Latvia's constitutional identity. In a situation like this, the supremacy of the Satversme's fundamental principles is envisaged. The Constitutional Court has characterised these principles as such that define "the foundations of an independent, sovereign and democratic republic, based on the rule of law and fundamental rights" (Constitutional Court, 2009a). The Constitutional Court has mentioned the following as such fundamental principles: a person's fundamental rights and freedoms, democracy, the sovereignty of the state and the people, separation of powers and the rule of law (Constitutional Court, 2009a). In the context of shared reservation of the national constitutional courts vis-à-vis the EU, the position chosen by the Constitutional Court is pronouncedly friendly, because the highlighted principles of the Satversme are also the values of the EU, and a potential contradiction with EU law in such cases would be a rare and rather extreme case. In the judgment regarding Latvia's accession to the EU, membership in the EU was conceptually examined from an open and friendly position (Constitutional Court, 2009a; Claes, Reestman, 2015).
The Constitutional Court is also open to dialogue with the CJEU, accepting its obligation as a Member State's supreme instance court whose rulings are final, to refer a question to the CJEU regarding interpretation of the law for a preliminary ruling (Constitutional Court, 2009b). The Constitutional Court has several times exercised its right to refer a question to the CJEU for a preliminary ruling (Constitutional Court, 2017a, 2019a, 2020a, 2020b). This promotes dialogue between the Constitutional Court and the CJEU, reinforcing in legal reality the openness of the Latvian legal system to EU law.

\section{Challenges of Europeanization in legal reality}

Accession to the EU did not complete the Europeanization of the Latvian legal system because membership in the EU requires appropriate application of EU law in the Latvian legal system. Likewise, the Latvian legal system co-participates in the common development of EU law and, equally to the legal systems of other Member States, has the obligation to be involved and participate in the further development of the EU.

The effectiveness of EU law is ensured by the fact that each Member State's legal system and its mechanisms apply EU law directly and immediately. The Latvian courts ensure application in concrete cases not only of national law but also of EU law norms. This demands high legal qualification - to discern an EU law dimension in the particular case and to find a just solution to the case that would promote the rule of law and the effectiveness of EU law (Ziemele, 2019)

EU law is not an exclusive area of law strictly isolated from national law. EU law may affect almost all issues to be resolved within the national system of courts, and the routine professional skills of a lawyer include equal proficiency in both national and EU law. In particular, in instances of potential collision, a lawyer is expected to have the skills to find a solution and to both promote the effectiveness of EU law and ensure protection for Latvia's constitutional identity. Following accession to the EU, parties applying EU law must interpret the norms of national law in compliance with the findings expressed in the judgments of the CJEU (Neimanis, 2004, 156-157). Knowledge of the methodology of applying legal norms that comply with the traditions of continental European law facilitates application of EU law and achieving the purposes of the EU (Neimanis, 2011).

The Constitutional Court has underscored, in particular, the legislator's responsibility to take into account the requirements of EU law in drafting new legal regulation (Constitutional Court, 2018c). Pursuant to the principle of good legislation, the legislator must ensure assessment of the compatibility of intended national 
regulation with EU law and must promote adoption of sustainable regulation that reinforces democracy. The legislator has the obligation to take account of even such legal regulation of the EU that has not yet entered into force, to promote achieving the EU's aims (Constitutional Court, 2019b). A substantial breach of the obligation to comply with EU law may be grounds for the Constitutional Court to find an adopted legal norm as incompatible with the principle of good legislation and void (Constitutional Court, 2019c).

An increase in the number of questions for preliminary rulings referred by the Latvian courts shows that the Latvian legal system has become accustomed to EU law. Since accession to the EU, the Latvian courts have referred 90 questions to the CJEU for a preliminary ruling, and, until summer of 2020, the CJEU had already adopted 80 preliminary rulings based on questions referred to it by the Latvian courts. The questions referred to the CJEU for preliminary rulings reflect the contribution made by practitioners from the court system to identifying problematic legal issues. The dialogue between the CJEU and national courts in the form of preliminary rulings is one of the mechanisms for developing EU law. Quite recently, the President of the CJEU, Koen Lenaerts, expressed gratitude to the Latvian courts, in particular to the Supreme Court, for successful dialogue in the application of EU law and the ability to ask complicated legal questions which were important not only for the Latvian legal system but for the entire European legal space (Kalnina, 2019). Likewise, it is worth underscoring that, although the European Commission has initiated infringement procedures against Latvia, as indeed it has against any other Member State of the EU, so far financial sanctions for violations have not been applied to Latvia.

This strongly suggests that in the years following accession to the EU the Latvian legal system in general has been able to cope with the application of EU law (Buka, 2017, 44). At the same time, the Latvian legal system would in the future be expected not only to apply EU law correctly but to become more intensively involved in discussions on the development of EU law. This, in particular, applies to Latvian legal science. EU law is unique because it is shaped and developed by legal scholars simultaneously in all Member States of the EU. In the development of EU law, the opinion of legal science from all national legal systems is important, and is a unique opportunity for the legal system to influence the future of EU law. This could be the direction in which to expect the next level in Europeanization of the Latvian legal system, becoming not so much a user of EU law but rather a co-creator of EU law.

Main findings and most important tasks

\section{Main findings}

Latvia's membership in the EU has been able to ensure the return of the Latvian legal system to the legal family of continental Europe and promoted Latvia's economic development and sense of security. Membership in the EU is testimony, of a kind, to the success and quality of Latvia's legal system.

Within the system of Latvia's constitution, belonging to common European legal space is marked as one the elements of Latvian constitutional identity, which defines the openness of the Latvian legal system to EU law and its friendliness towards the process of European integration. At the same time, legal policy tenets as defined by the Constitutional Court have protected the Latvian legal system from potential collisions between national law and EU law and have facilitated application of EU law in legal reality. The Latvian Constitutional Court is one of the EU law-friendliest constitutional courts in Europe, and this determines the common attitude of the Latvian legal system.

The Latvian legal system has been able to ensure Latvia's full membership in the EU - in Latvia, EU law is applied on the same level and in the same quality as in the other Member States of the EU, and consistent progress in this area is observed in legal reality. In the further process of Europeanization of the Latvian legal system, Latvia should reinforce its positions not only as a proper user of EU law but also as an active co-creator of EU law, contributing to discussion on the development of common European legal space. Likewise, Europeanization of the Latvian legal system was not completed by accession to the EU. Membership in the EU entails a permanent obligation to maintain the principles of a democratic state governed by the rule of law and methodology for the application of legal norms compatible with those principles in legal reality.

\section{Most important tasks}

The quality of laws and other regulatory enactments should be improved by reviewing in due time the impact of EU law on regulation and developing sustainable legal regulation compatible with EU law.

Knowledge and skills in working with EU law of parties applying the law should be improved in legal reality. The competence of the parties applying the law to discern an EU law dimension in a pending case and to resolve it in 
a qualified way needs to be developed. For fully-fledged participation in common European legal space, proficiency in the official languages of the EU should be promoted in a targeted way. This, in particular, applies to French, which is the working language of the CJEU.

Latvian legal science should become more visibly and extensively involved in scientific discussion of common European legal space and contribute more and in a more targeted way to the development of EU law.

Openness to EU law and a friendly attitude towards the process of European integration established by the Constitutional Court should be strategically promoted. Growing Euroscepticism would not facilitate development of the Latvian legal system and would undermine a democratic state governed by the rule of law in Latvia. 


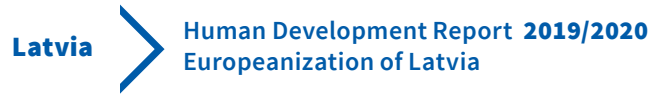

Part 2

Society, media and values

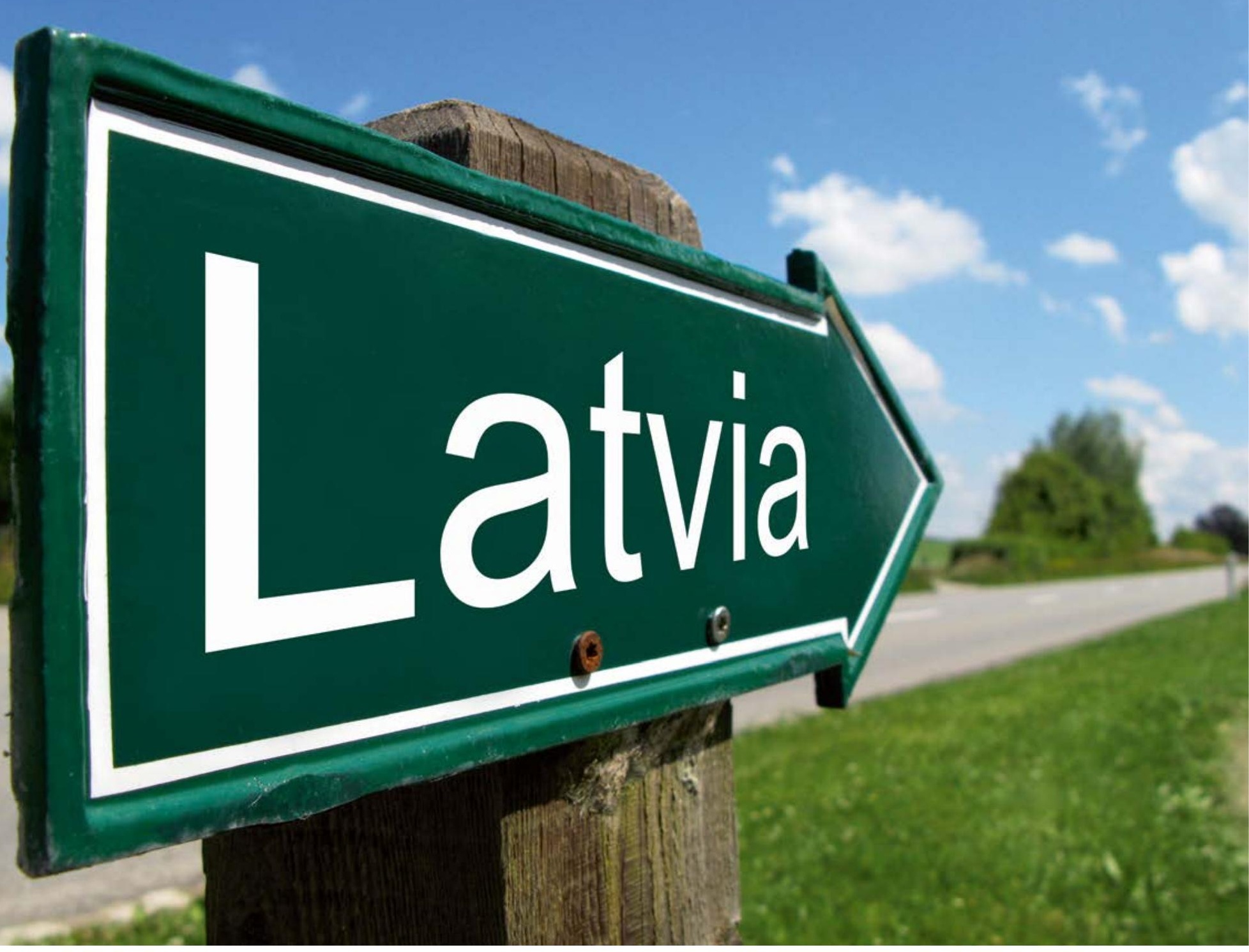




\subsection{Poverty and inequality in Latvia. In line with European values?}

\section{Baiba Bela}

Discussions and studies on the development of states almost always include a focus on issues of inequality. It is underscored in studies that poverty and inequality hinder social cohesion, reciprocal trust among the people, and trust in the government, as a result of which economic growth also suffers (UNDP, 2019; Stiglitz, 2012; Wilkinson \& Pickett, 2010). Income inequality is also linked to inequality in terms of capability and opportunities in education and health as well as inequality in access to technologies and skills in using them. Inequality begins before birth, and the difficulties that it causes accumulate throughout life, with mutually negative reinforcing effect. Positive factors also accumulate and are mutually reinforcing (UNDP, 2019). For example, the life expectancy of a 25 year-old inhabitant of Latvia with a low level of education is 10 years shorter compared to a 25 year-old inhabitant of Latvia with a high level of education (Latvija. Valsts veselības pārskats, 2017). Moreover, in countries with high inequality, parents pass down to their children both economic successes and economic failures to a much larger extent than in countries with lower inequality (Corak, 2013). It has been proven in studies on income inequality and intergenerational mobility that in countries with high inequality the level of parents' income determines the income of their children when they are adults to a much larger extent than their adult children's efforts to ensure their own welfare (UNDP, 2019; Corak, 2013). This means that in countries with lower income inequality, such as Finland and Norway, children have greater prospects for shaping their future irrespective of their parents' means (intergenerational income mobility is much larger). In contrast, in countries with high inequality, such as the USA, the UK or Latvia, the possibilities for children to be the architects of their own fortune, irrespective of their parents' income, are significantly smaller (UNDP, 2019). Therefore the issue of decreasing inequality is broader than only Europeanization of Latvia - it is, indeed, a matter of the future.

This chapter will develop the discussion on whether, in terms of issues of social security and social policy, development trends in Latvia have gone hand in hand with trends in Europe. Although during thirty years of independence and more than fifteen years since accession to the EU Latvia has achieved a great deal in terms of material welfare, nevertheless it continues to be among the EU Member States with the highest poverty and social exclusion indicators (in 2019, the EU average was $22.4 \%$, in Latvia $28.2 \%$ (Eurostat, 2019)), the highest indicators of income inequality (in 2018, the EU average Gini index was 30.8, in Latvia 35.6 (Eurostat, 2020a)), low minimum salary (in 2019, in six states it is above EUR 1500, whereas Latvia with EUR 430 a month is among the four states where the minimum salary is still below EUR 500 (Eurofond, 2019)) and with relatively low support for people in situations of crisis and poverty (in 2018 , the budget for social protection was $19.2 \%$ of GDP as the EU average, whereas in Latvia it was $11.6 \%$ of GDP (Eurostat, 2020b)). It seems that Europeanization in dealing with social issues has been insufficient. What is the level of Europeanization in matters of social security that can be discussed by analysing the indicators of poverty and inequality in Latvia? What do people in Latvia think about decreasing poverty and income inequality?

First, the EU guidelines on social issues and development of social policy will be characterised and the steps taken by Latvia's social policy and social security system towards Europeanization will also be examined. Afterwards, the focus will turn to indicators of the proportion of inhabitants subject to the risk of income inequality and poverty as well as changes in those indicators before and after social transfers. In conclusion, insight will be given into the attitudes of people in Latvia towards income inequality, perceptions of the causes of poverty, and what they expect from the government in terms of decreasing income inequality and poverty.

\section{European traditions and the EU's position on matters of social rights and social security}

Europeanization in the narrower sense means the impact of the European Union's political agenda on decisions by the Member States. In a broader sense, Europeanization means following the aims and values of the EU. Reinforcement of the EU's values and people's welfare, sustainable development - which also includes social progress and the fight against social exclusion and discrimination - are among the EU's main aims. Respect for other human beings, freedom, democracy, equality, the rule of law and human rights are European values which have been embedded in the EU Charter of Fundamental Rights and the Lisbon Treaty (Shortly about EU, n.d.). Having originated in 1958 as economic 
cooperation between six European states (Belgium, France, Italy, Luxemburg, the Netherlands and Germany), by 2020 the European Union already consisted of 27 Member States, and nowadays the aims of cooperation significantly exceed solely economic cooperation, including diverse policy areas, from climate, environment and health to foreign policy, security, and migration. Although social policy falls within the competence of each Member State, nevertheless it is influenced by the common agenda of the EU - the need to respect the EU's aims and values, principles defined in framework documents and the direction set in strategic development documents. The EU's perspective on issues of social security has been shaped by the need to harmonize two competing aims which are difficult to reconcile, namely high productivity and high social protection. Moreover, the processes of EU market integration cause direct and indirect pressure on the Member States and decrease the capacity of national welfare states to implement autonomous social policies (Aust et al., 2004; quoted from: Cunska, Muravska, 2009). Although matters of economic growth have been at the centre of the EU's attention for a long time, in 1999 the European Commission announced a concerted strategy in the area of social protection and in 2000 the Council of the EU approved the open method of coordination (OMC) for eliminating poverty and social exclusion, thus for the first time in the EU's history placing social issues on the political agenda of the EU. The OMC is a form of governance for integrated solutions to social issues that respect the diversity of social security systems and welfare state models of different EU Member States. Europe's strategy for smart, sustainable and inclusive growth "Europe 2020" (2010) for the first time advanced decreasing poverty as a strategic development goal, the plan being to decrease the number of Europeans at risk of poverty by 20 million. The next step towards a more uniform approach to tackling social issues is the EU Social Rights Pillar, which the European Parliament, the Council and the Commission agreed on at the Gothenburg Social Summit of 2017. The EU Social Rights Pillar is based on 20 principles, structured in three categories: 1) equal opportunities and access to the labour market; 2) fair working conditions; 3) social protection and inclusion (European Commission, n.d.). Special emphasis is placed upon ensuring a life consistent with human dignity, receiving adequate remuneration at work or, if necessary, adequate social protection or assistance at all stages of life, for working-age persons combining minimum income benefit with incentives for reintegration in the labour market.

\section{Europeanization of Latvia's social security system}

Following restoration of independence in 1991, the trend to move as far away as possible from the principles of socialism prevailed in all areas. In the creation of Latvia's social security system, this meant shifting the responsibility for personal welfare from the state to the individual, reinforcing the link between social insurance contributions and expenses in the case of unemployment or disease, as well as with pension provision. (Rajevska \& Rajevska, O., 2019). Decision-makers were predominantly convinced that economic growth and resolution of economic problems would automatically mean resolution of social problems (Rajevska, 2018). In view of high income inequality indicators and since at times of economic growth the proportion of people at risk of poverty increases in Latvia, politicians and decision-makers should listen to statements from the world's leading economists that, throughout capitalism, free market principles are the same but welfare outcomes are very different (Stiglitz, 2015). For instance, the indicators of poverty and income inequality differ significantly in the USA and European states. This reveals the role of the welfare state in balancing out market deficiencies with the help of taxation and social security systems. Europe is a region with the lowest income inequality indicators in the world (UNDP, 2019). Since high inequality indicators are hardly compatible with European fundamental values - human dignity, equality and progress towards the welfare of all - the following sections will outline the most important steps towards Europeanization in Latvia's social security system and discuss the vision of a more equal society included in strategic documents on Latvia's development and whether, until now, these aims have facilitated actual change and whether the system of social protection ensures the right to live with dignity.

Substantial reforms towards Europeanization of the social security system have taken place since 1995 when the Saeima expressed the wish to accede to the European Union. In 2003, Latvia, as a candidate country, signed the Joint Inclusion Memorandum, which defined two main long-term aims of social policy "implementation of preventive measures for eliminating risk factors of poverty and social exclusion and of support measures for the groups of inhabitants most at risk of social exclusion" (Lāce, 2012, 122). On the basis of main lines of action as defined in the Joint Inclusion Memorandum, a National Action Plan for Decreasing Poverty and Social Exclusion (2004-2006) was drafted and reports on the strategy for social protection and social exclusion were prepared (2006-2008; 2008-2010).

Since 2011, the social situation and social security policy are regularly monitored on the EU level, using as a point of reference the common aims advanced by the "Europe 2020" strategy and the national aims of the Member States. However, the EU's approach to analysis of the social situation and social protection balances between developing a positive social image of Europe and delicate references to problems. Almost all Member States are slowly advancing towards European social aims, but the progress made by these states differs enormously. It was clear by 2019 that the aim defined 
by the "Europe 2020" strategy, namely to decrease the number of Europeans at risk of poverty by 20 million, would not be achieved because in 2018 the decrease amounted only to five million (European Union, 2019).

In annual reports by the EU Social Protection Committee, Latvia's indicators look very good (see, for example, European Union, 2019) because the progress made by states is not measured in international comparison but by measuring the changes in each state compared to data from 2008, which constitute the reference threshold for meeting the aims advanced by "Europe 2020". Since polarisation of income in 2008 was particularly high in Latvia (Gini index 37.5) and poverty indicators were particularly high $(26.4 \%$ of the population were at risk of poverty), it follows that the choice of data of that year as the reference point was particularly favourable for Latvia, in that almost all indicators chosen for monitoring reveal improvements. The descriptive part of the report underscores the achievements of each government. For example, it mentions that Latvia has approved a "Plan for improving the minimum income support system for 2020-2021" but does not analyse whether previous plans produced by the government for aligning the minimum income had ever been implemented and whether the currently planned measures for aligning the minimum income level are adequate to provide for the basic needs of the target group (European Union, 2019, 28). Monitoring is not entirely uncritical; however, problems are delicately referred to as challenges. Latvia is mentioned as one of the countries that face significant challenges in connection with indicators of risks of poverty and social exclusion, income inequality, housing deprivation, pension levels, the effectiveness of social assistance and a gap in the accessibility of social assistance. Health care services in Latvia are also characterised as a challenge (European Union, 2019, 34-37). Latvia has also received very clear recommendations from the Council of the EU, repeatedly underscoring that the level and adequacy of social benefits should be improved, the levels of minimal income should be aligned and measures to help the unemployed integrate in the labour market should be made more effective (Council of the European Union, 2015, 2016, 2017, 2018). A reference to these recommendations is included in the "plan for improving the minimum income support system for 2020-2021". However, resources for implementing similar previous plans have not been found in the budget since 2014, but Constitutional Court rulings, which will be examined below, give rise to the hope that, this time, the government will have to ensure that the plan is implemented. It seems that the delicate approach taken by European structures towards solutions to social issues in the Member States does not provide incentives for policymakers to solve problems substantively (criticism is expressed very gently, recommendations may be disregarded, and so on)

Latvia's national strategic planning documents also focus on decreasing inequality and poverty. However, it should be admitted that until now it has been specific. In Latvia's strategy for sustainable development "Latvia 2030" - equality of opportunity and formation of a middle class is an important aim of strategic development: "With increasing GDP, to decrease social and income inequality - to promote social inclusion, decrease the risks of poverty, foster development of a socially and economically stable middle class in society." (Saeima, 2010, 24). However, the reasoning behind this aim is not based on EU values - on human dignity or freedom which cannot be exercised in conditions of poverty and inequality, but rather on an instrumental approach to the human being as an economic resource because "in the long-term, social inequality may significantly diminish the economic potential and opportunities for growth of the main national resource - human capital" (Saeima, 2010, 24). The authors of the "Latvia 2030" strategy point to the structural causes of inequality, the connection between high income inequality and low expenditure for social protection as well as the need to implement a complex approach to short-term poverty elimination and to create social programmes that meet the needs of groups at risk of poverty and social exclusion. However, data do not show that an effective policy would follow from the strategic vision. For example, the government gave its conceptual consent to aligning the minimum income level as long ago as 2014 (Welfare Ministry, 2014) but still has not found the possibility to implement it. Likewise, expenditure for social protection remains low both compared to GDP and as part of the total national budget structure, compared to average expenditure in the EU Member States (Figure 2.1.1.).

The same can be said about the aims advanced in the medium-term development planning document "The National Development Plan of Latvia for 20142020" (hereinafter - NDP2020) and its implementation in connection with social protection or decreasing inequality and poverty (Cross-Sectoral Coordination Centre, 2012). It needs to be underscored that NDP2020 is directly linked to (financial) Europeanization of Latvia because use of the EU multi-annual budget (2014-2020) was considered in drafting it. Although the summary index of income inequality S80/S20 quintile-ratio is mentioned as one of the strategic indicators of NDP2020 (which theoretically shows that decreasing income inequality is a strategic aim), decreasing inequality has a subordinate role in priorities and lines of action. Reinforcing individual securitability (ensured by the state together with society) and strengthening the middle class are the most important in the "Human Securitability" priority. Decreasing the income gap and poverty are examined in interconnection with decent work, actually ignoring those groups that are outside the labour market. Serious attention is paid only to decreasing child poverty. This may have facilitated development of a successful policy and a decrease in child poverty from $24.4 \%$ in 2012 to $14.5 \%$ in 2018 (Central Statistical Bureau of Latvia, 2020). Focusing on ensuring 
economic breakthrough, the no less important role of social protection has been forgotten in creating a future for Latvia in compliance with European values and aims. As noted by politologist Feliciana Rajevska, a specific feature of Latvia's political process is "stability of the political elite and great autonomy from the electorate in the process of implementing reforms and adopting decisions, a remarkably high degree of societal fragmentation. This significantly hinders the possibilities of social dialogue and, at the same time, weakens the introduction and functioning of a mechanism for social responsibility" (Rajevska, 2018, 10). Latvia lacks qualitative social discussion on the role of social security, inequality and poverty as social problems that hinder development.

Alongside controversial policy planning documents, the basic principles for the functioning of the nationstate, enshrined in the Preamble to the Satversme of the Republic of Latvia in 2014, must be mentioned as a positive step towards Europeanization of the legal framework for social policy as these principles are based on important European values - democracy, the rule of law and the principle of a socially responsible state. This principle comprises the state's duty to ensure minimal pre-conditions for existence with dignity; the state's obligation to ensure protection in the case of social risk; the state's obligation to care for social justice and the individual's link with society (Kovalevska, 2018). The state's obligation to develop and implement a social policy that ensures social rights and preconditions for equal opportunities follows from this principle because the state, even in the conditions of a market economy, assumes responsibility for the welfare of its citizens and does not leave this entirely in the hands of the citizens themselves. It must be underscored that the legal framework established in Latvia places no obstacles for socially responsible development, which in turn clears the way for discussion of lack of awareness, knowledge or political will for appropriate action.

Family policy is a positive example, implementing the social investment approach (Rajevska \& Rajevska, 2020). Taking into account the decreasing number of inhabitants, ageing, and a low birth rate, as well as continuously high poverty indicators for families raising three or more children, reform in state family benefit was supported in 2017. At the same time, sociologist Tana Lāce notes that children have not been singled out as a priority target group in social policy for reducing poverty. The researcher identifies serious deficiencies in active employment policy, which hinders increasing parents' involvement in the labour market, hence improving the welfare of families with children. Child poverty has significantly decreased as the result of demographic policy rather than due to social policy (Lāce, 2018). One of the most important elements in demographic policy is increasing state support for the second, third and successive child(ren), significantly decreasing the indicators of child poverty and poverty of large families.
The tax reform of 2018 should be mentioned as the next positive step. This introduced some progressivity in tax contributions, decreased the tax burden for those on a low income (increasing the non-taxable minimum, tax advantages for dependent family members) and reinforced the plan for increasing the minimum salary. It is especially important that, at the end of the day, attempts by some parties to achieve regressivity in the tax system did not gain the Saeima's support. Perhaps a certain role in this was played by active public discussion involving international experts and Latvian specialists defending progressivity in tax contributions and decreasing the tax burden for those on low salaries. However, it is too early yet to speak of the positive consequences of the reform because experts viewed the benefits for recipients of low salaries as insignificant - the salary should be close to the average to fully use the planned advantages, whereas, essentially, recipients of low salaries have only a couple of extra euros left in their wallets (Dārziņa, 2019).

Changes that have received little public attention come slowly and with difficulty. Latvia still has not fully ratified the "European Social Charter (Revised)", which it signed in 2007 and ratified in 2013. The Saeima only partially ratified Article 4 of the Charter on the right to fair remuneration. In 2020, Latvia had the second lowest minimum salary in the whole of the EU, only Bulgaria having a lower one. Minimum salary below the threshold of EUR 500 also applies in Hungary and Romania (but in both countries is higher than in Latvia). Even our neighbours - Lithuanians and Estonians were able to surmount the EUR 500 minimum salary threshold in 2019. As to indicators of GDP and average salary, Latvia is in a rather similar situation, which raises the question - what exactly is it that hinders increasing the minimum salary in Latvia as well? If the Latvian government seriously wishes to improve the birth rate and curb emigration, then income that allows living with dignity is essential. And this means the right to fair remuneration for people in Latvia as well.

Faster Europeanization of social policy in Latvia and more decisive action to decrease poverty and income inequality could be implemented in Latvia in the coming years. On the one hand, this could be facilitated by "The National Development Plan for Latvia 2021-2027", adopted by the Saeima on 2 July 2020. The approach taken in the Plan and the strategic aims defined give grounds for hope that significant changes have occurred in the mentality of policymakers. For the first time, the reference-points for the future are not economic growth but equal opportunity, quality of life, a knowledge society, and responsibility in environmental and demographic matters. The economy is an instrument for achieving those aims, decisive for public welfare, rather than being an end in itself to which people are subordinated, as was typical of the wording in NDP2020. The movement away from the neoliberal approach is confirmed by the commitment to bring Latvia closer "to 
Table 2.1.1. Gini coefficient in Latvia and the EU (\%)

\begin{tabular}{lccccccccccccccc}
\hline & 2004 & 2005 & 2006 & 2007 & 2008 & 2009 & 2010 & 2011 & 2012 & 2013 & 2014 & 2015 & 2016 & 2017 & 2018 \\
\hline Latvia & 36.2 & 38.9 & 35.4 & 37.5 & 37.5 & 35.9 & 35.1 & 35.7 & 35.2 & 35.5 & 35.4 & 34.5 & 34.5 & 35.6 & 35.2 \\
\hline $\begin{array}{l}\text { ES-25 (2004-2006), } \\
\text { ES-27 (2007-2013, }\end{array}$ & 30.6 & 30.3 & 30.6 & 31.0 & 30.6 & 30.5 & 30.8 & 30.5 & 30.5 & 31.0 & 31.0 & 30.8 & 30.6 & 30.8 \\
ES-28 (2013-2020) & & & & & & & & & & & & & & & \\
\hline
\end{tabular}

Source: CSB, 2019 and Eurostat, 2020.

the model of public governance of the Nordic States, which comprise reciprocal trust in society and caring for one another, targeted progress towards achieving commonly set aims, societal solidarity and honest, responsible and transparent distribution of the public resources allocated for the common good." (NAP2027, 2020, 10).

On the other hand, a significant coercive factor towards Europeanization were rulings by the Constitutional Court in three cases initiated on the basis of the Ombudsman's applications - on compliance with the Satversme of the guaranteed minimum income level (EUR 53 for a long time, EUR 64 since 1 January 2020) (case No. 2019-24-03'1), on the amount of social security benefit for unemployed persons with disabilities and seniors (which for persons disabled since childhood is EUR 122.69 per month; for other disabled persons - EUR 80 per month; for persons entitled to old age pension EUR 64.03 per month) (case No. 2019-27-03²) and on compliance with the Satversme of the threshold of EUR 128.06 for recognising a person as being needy (case No. 2019-25-03 ${ }^{3}$ ). In all three cases, the decision was made to recognise the contested legal norms as being incompatible with the Satversme and instruct the Saeima and the Cabinet to draft Satversme-compatible regulation by the beginning of 2021 . The financial resources referred to in these three laws were recognised as insufficient to ensure a needy person a life that would be compatible with human dignity. Changes in the regulation on minimum income will also facilitate changes in other income levels because income gained from salaried work should be higher than the income that can be gained from social assistance so that people would not lose the motivation to participate in ensuring their own welfare.

The next section discusses poverty and inequality in Latvia in comparison with the other EU Member States, the incompatibility of minimum income levels in terms of providing for basic needs even minimally, and a comparative analysis of the government's expenditure for social protection.

\section{Time passes but poverty and inequality remain stable}

Until now, alongside growing economic welfare, the proportion of people at risk of poverty and / or income inequality has also been increasing, with indicators remaining persistently above the EU average indicators (Table 2.1.1.; Table 2.1.2.). This means that the more needy inhabitants gain less from economic development compared to those who earn average and higher salaries. The Gini coefficient - the most frequently used indicator internationally, which characterises income inequality - in Latvia significantly exceeds the EU average indicators (Table 2.1.1.). It should be borne in mind that, as we have seen, Europe is the region in global terms with the lowest income inequality. For example, in OECD states outside the EU the indicators of income inequality are also higher - in the USA and Turkey approximately 40, compared with Chile and Mexico with 46 (OECD, 2020).

Theoretically, the point of departure in developing national social policy is creation of a living and working environment compatible with human dignity, on the basis of the state's economic capabilities and in compliance with society's system of values (Nacionālā enciklopēdija, 2020). Effective action by the state to decrease income inequality and prevent poverty testifies to Europeanization in the social area. The state's ability to achieve a substantial decrease in the number of people at risk of poverty by using the instruments at its disposal are well revealed by the indicators of

\footnotetext{
1 “On Compliance of Para 2 of the Cabinet Regulation of 18 December 2012 No. 913 "On the Guaranteed Minimum Income Level” with Articles 1 and 109 of the Satversme of the Republic of Latvia."

2 "On Compliance of Para 2 of Cabinet Regulation of 22 December 2009 No. 1605 "Regarding the Amount of State Social Security Benefit and Funeral Benefit, Procedures for Review thereof and Procedures for Granting and Disbursing Benefits" with Article 1, Second Sentence of Article 91 and Article 109 of the Satversme of the Republic of Latvia."

3 "On Compliance of the words "if the average monthly income during the last three months per each member of the family does not exceed EUR 128.06" of Para 2 of the Cabinet Regulation of 30 March 2010 No. 229 "Regarding Recognising a Family or Person Living Separately as Needy" with Articles 1 and 109 of the Satversme of the Republic of Latvia."
} 
Table 2.1.2. The proportion of people at risk of poverty in Latvia and the EU (\%)

\begin{tabular}{lccccccccccccccc}
\hline & 2004 & 2005 & 2006 & 2007 & 2008 & 2009 & 2010 & 2011 & 2012 & 2013 & 2014 & 2015 & 2016 & 2017 & 2018 \\
\hline Latvia & 19.4 & 23.5 & 21.2 & 25.9 & 26.4 & 20.9 & 19.0 & 19.2 & 19.4 & 21.2 & 22.5 & 21.8 & 22.1 & 23.3 & 22.9 \\
\hline $\begin{array}{l}\text { ES-27 (2007-2013), } \\
\text { ES-28 (2013-2020) }\end{array}$ & & & & & 16.6 & 16.4 & 16.5 & 16.8 & 16.8 & 16.7 & 17.2 & 17.3 & 17.3 & 16.9 & 17.1 \\
\hline
\end{tabular}

Source: CSB, 2019 and Eurostat, 2020.

\section{Table 2.1.3. Poverty risk indicators before and after social transfers}

\begin{tabular}{|c|c|c|c|c|c|c|c|c|c|c|c|c|}
\hline GEO/TIME & 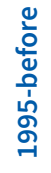 & 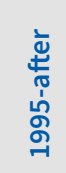 & 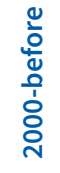 & 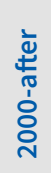 & 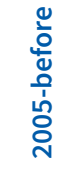 & 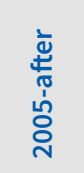 & 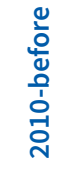 & 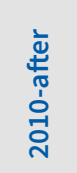 & 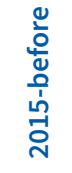 & 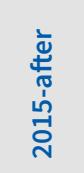 & 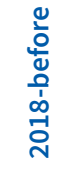 & 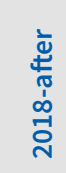 \\
\hline $\begin{array}{l}\text { ES } \\
\text { (ES15-1995, } \\
\text { ES25-2004, } \\
\text { ES27-2007, } \\
\text { ES28-2013, } \\
\text { ES27-2020) }\end{array}$ & & & & & & 16 & 43.6 & 16.5 & 44.7 & 17.3 & 43.6 & 17.1 \\
\hline \multicolumn{13}{|c|}{ ECC founding states } \\
\hline Belgium & 42 & 16 & 40 & 13 & 41.9 & 14.8 & 41.3 & 14.6 & 43.3 & 14.9 & 41.9 & 16.4 \\
\hline Germany & 38 & 15 & 39 & 10 & 43.3 & 12.2 & 43.9 & 15.6 & 43.9 & 16.7 & 42 & 16 \\
\hline France & 42 & 15 & 41 & 16 & 44.6 & 13 & 44.5 & 13.3 & 44.3 & 13.6 & 45.7 & 13.4 \\
\hline Italy & 40 & 20 & 42 & 18 & 43.2 & 19.2 & 44 & 18.7 & 46 & 19.9 & 45.8 & 20.3 \\
\hline Luxemburg & 40 & 12 & 39 & 12 & 40.6 & 13.7 & 45 & 14.5 & 44.7 & 15.3 & 46 & 18.3 \\
\hline Netherlands & 38 & 11 & 35 & 11 & 36.7 & 10.7 & 36.9 & 10.3 & 39.1 & 11.6 & 37.9 & 13.3 \\
\hline \multicolumn{13}{|l|}{ Baltic States } \\
\hline Latvia & & & 45 & 16 & 40.3 & 19.4 & 44.8 & 20.9 & 40.9 & 22.5 & 39.1 & 23.3 \\
\hline Lithuania & & & 40 & 17 & 42 & 20.5 & 49 & 20.5 & 42.8 & 22.2 & 41.8 & 22.9 \\
\hline Estonia & & & 42 & 18 & 38.9 & 18.3 & 40.8 & 15.8 & 39.4 & 21.6 & 38.7 & 21.9 \\
\hline \multicolumn{13}{|c|}{ Scandinavian welfare states } \\
\hline Denmark & & 10 & & & 37.9 & 11.8 & 39.3 & 13.3 & 40.6 & 12.2 & 39.2 & 12.7 \\
\hline Finland & & & 32 & 11 & 40.4 & 11.7 & 40.7 & 13.1 & 43.4 & 12.4 & 43.2 & 12 \\
\hline Sweden & & & & & 41.5 & 9.5 & 43.9 & 14.8 & 44.7 & 16.3 & 44.3 & 16.4 \\
\hline Norway & & & & & 37.9 & 11.4 & 38.6 & 11.2 & 40.3 & 11.9 & 42.5 & 12.9 \\
\hline
\end{tabular}

Table created by the author, using data from Eurostat 2020c, 2020d. 


\section{Figure 2.1.1. General governmental expenditure for social protection (2019) (\% of GDP)}

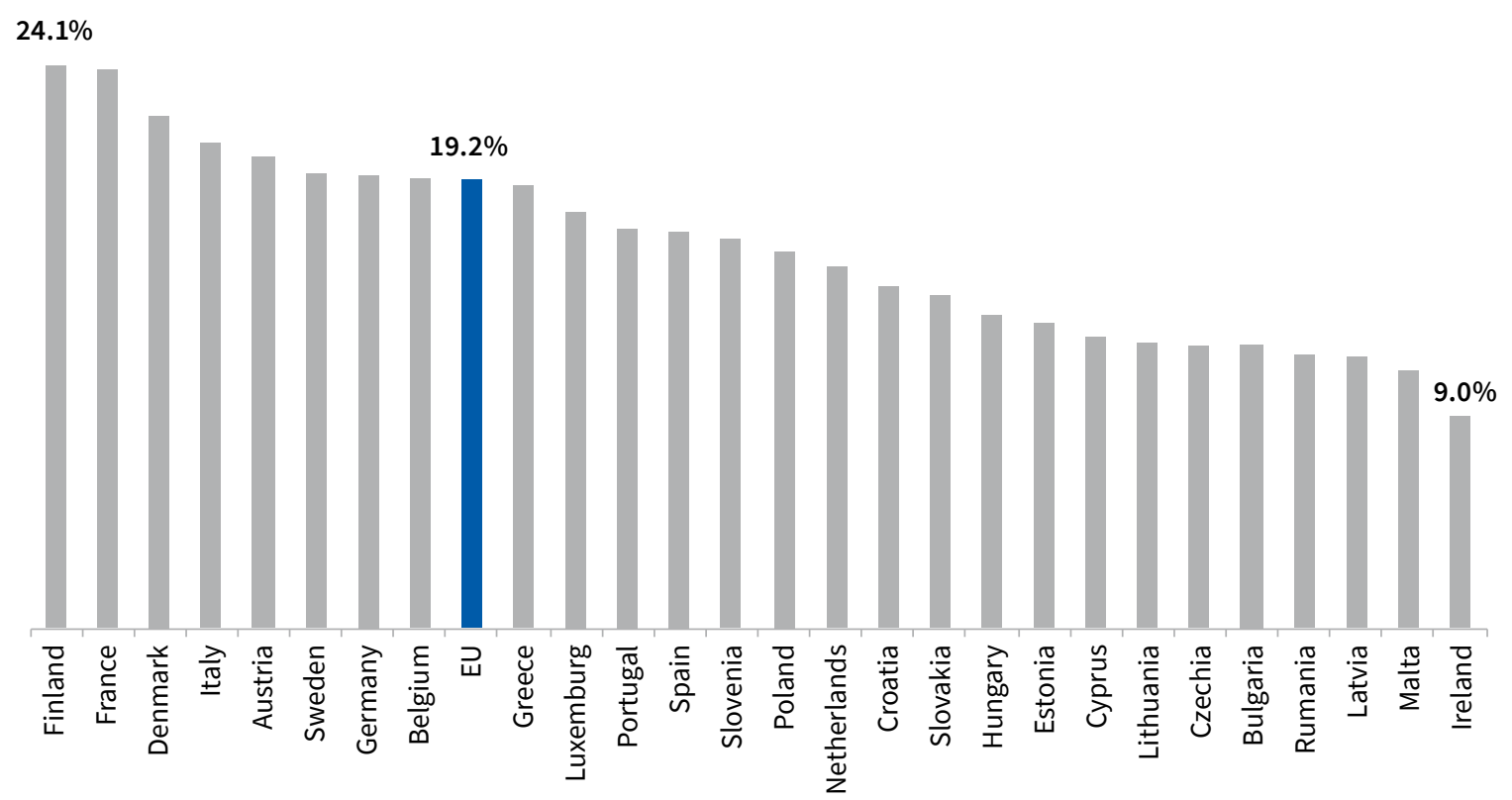

Source: Eurostat, 2020b.

the proportion of inhabitants at risk of poverty in the EU Member States before and after social transfers (Table 2.1.3.). The fact that in Latvia the proportion of people at risk of poverty before social transfers is below the EU average - but after transfers, above it - testifies to the insufficient use made of the state's ability to decrease poverty effectively. For instance, in 2018, before social transfers the average EU proportion of people at risk of poverty was $43.6 \%$, whereas in Latvia - only $39.1 \%$. Although after social transfers this also decreased significantly in Latvia (from $39.1 \%$ to $23.3 \%$ ), the average decrease in EU countries is much more significant (from $43.6 \%$ to $17.1 \%$ ) (Table 2.1.3. shows EU average indicators, indicators of the EEC founding States, states of the Scandinavian welfare model, and the Baltic States are used for comparison). For example, in Finland, the proportion of people at risk of poverty before social transfers in 2018 was $43.2 \%$, some 4\% higher than in Latvia, whereas after social transfers - almost two times less (only 12\%) (Eurostat, 2020c, d).

In absolute numbers, the social protection budget in Latvia is increasing every year and has doubled compared to 2006 (Central Statistical Bureau, 2019). However, the ratio of this expenditure in relation to GDP is and remains one of the lowest in the EU. In 2018, average expenditure for social protection in the EU 28 stood at $18.6 \%$ of GDP, whereas in Latvia the figure was $11.6 \%{ }^{4}$. The threshold of income that triggers the right to receive social assistance is unacceptably low. Also, social assistance is insufficient, moreover, with low coverage (World Bank, 2013; ESPN, 2015). The World Bank study notes that $40 \%$ of social assistance recipients have received it only once and for a short period. Furthermore, support could be more generous (World Bank, 2013). In analysis of the European Social Policy Network on minimum income levels, from among 35 countries reviewed, Latvia is mentioned as one of 14 countries where minimum income levels are assessed as being inadequate. Only five states (Czechia, Cyprus, Iceland, Liechtenstein, The Netherlands) were recognised as being generous in terms of social assistance, ensuring substitute income that was worthy of human dignity and adequate (ESPN, 2015). Local experts have also continuously pointed to insufficient action to prevent poverty and social exclusion (e.g., Bela, 2013; Bela, 2018; Lāce, 2012; Rajevska, 2018).

Until now, the most significant problem in decreasing poverty and ensuring sufficient social protection has been linked to setting inadequate minimum income levels and failure to implement the solutions that have been elaborated. The concept document "On Setting the Level of Minimum Income" was approved by the government in 2014 (Welfare Ministry, 2014) but, thus far, minimal steps have been taken to implement it. Minimum income levels - the guaranteed minimum income level (GMI) (EUR 53 per month, but since

\footnotetext{
4 Data provided by Eurostat and the Central Statistical Bureau of Latvia differ. The CSB homepage indicates that in 2018 expenditure for social protection amounted to $15 \%$ of GDP (see https://www.csb.gov.lv/lv/statistika/statistikas-temas/socialie-procesi/ sociala-drosiba/meklet-tema/2611-socialas-aizsardzibas-izdevumi-2018-gada)
} 
2019 - EUR 64) and the income level of a needy person (EUR 128.06) have not been substantially reviewed since 2009. The income level of a needy person corresponds to $17 \%$ of the income median in 2019 , but GMI is $8.5 \%$ of the income median in 2019: only a couple of euro cents above the threshold of absolute poverty. Both GMI and the income level of a needy person are too low to provide for basic needs and ensure minimum preconditions for existence that would be worthy of human dignity. These levels are set without concrete, substantiated methodology. The Constitutional Court noted that "defining the GMI level is an issue that is related to the state's obligation to establish a system of social security that would ensure protection of human dignity, levelling out of socioeconomic differences and sustainable national development" (Constitutional Court, 2020). The same can be said about other levels of minimum income - currently, they ensure nothing of the above mentioned.

Statistics on people's self-assessment regarding the amount of money per person that their household would need to make ends meet and the actual income at their disposal are useful to illustrate the extent to which the threshold of 128.06 has become outdated over these years and how living expenses have grown, how marked are the constantly increasing differences between income in the lowest and highest income quintiles (Table 2.1.4.). Differences between income needed and income at the disposal of households below the poverty threshold clearly illustrates the need for support to provide for household needs already at the poverty threshold, which is $60 \%$ of the income median in the state. The "Plan for Improving the Minimum Income Support System for 20202021" (2019) envisages establishing the criterion of a needy person's income at $40 \%$ of the income median in the state (EUR 198) and to set the GMI level at $50 \%$ of the income level of a needy person (EUR 99). It would be inadmissible if the state considers as an acceptable setting support for inhabitants who have ended up in the most difficult situation only at $13.5 \%$ of the income median (calculated on the basis of data from 2019, when the income median was EUR 751). In view of the fact that EUR 99 does not ensure even the minimum amount of healthy food but other types of social support are not mutually complementary, GMI will not suffice to ensure a needy person a life compliant with human dignity. EUR 99 complies with the means for each person in a household at risk of poverty in 2009 but undoubtedly cannot meet basic needs a decade later. The data of the Central Statistical Bureau on income at the disposal of households and the minimum necessary income per person in a household provide an insight into the amount of current and required income and expenditure that allows a more critical look at the plan for aligning minimum income levels. At the same time, the data clearly illustrate the gap between people with the lowest and the highest income - although the subjective assessment of the minimum necessary income differs almost twice, the actual income at disposal differs almost seven times (Table 2.1.4.)

\section{Table 2.1.4. Comparison of the lowest necessary net income for households to be able to make ends} meet and income at households' disposal (EUR)

\begin{tabular}{|c|c|c|c|c|c|c|c|}
\hline & All households & $\begin{array}{l}\text { Households below } \\
\text { the threshold of } \\
\text { poverty risk }\end{array}$ & $\begin{array}{c}\text { Group } \\
\text { of } 1^{\text {st }} \\
\text { quintiles }\end{array}$ & $\begin{array}{l}\text { Group } \\
\text { of } 2^{\text {nd }} \\
\text { quintiles }\end{array}$ & $\begin{array}{l}\text { Group } \\
\text { of } 3^{\text {rd }} \\
\text { quintiles }\end{array}$ & $\begin{array}{c}\text { Group } \\
\text { of } 4^{\text {th }} \\
\text { quintiles }\end{array}$ & $\begin{array}{l}\text { Group } \\
\text { pf } 5^{\text {th }} \\
\text { quintiles }\end{array}$ \\
\hline \multicolumn{8}{|l|}{2009} \\
\hline $\begin{array}{l}\text { Lowest necessary } \\
\text { net income (EUR) }\end{array}$ & 394.9 & 304.57 & 277.55 & 326.1 & 372.96 & 438.03 & 572.84 \\
\hline $\begin{array}{l}\text { Disposable income } \\
\text { (EUR) }\end{array}$ & 302.88 & 99.3 & 100.2 & 201.97 & 258.58 & 355.26 & 667.69 \\
\hline \multicolumn{8}{|l|}{2010} \\
\hline $\begin{array}{l}\text { Lowest necessary } \\
\text { net income (EUR) }\end{array}$ & 366.42 & 277.82 & 261.23 & 321.02 & 352.42 & 403.19 & 529.68 \\
\hline $\begin{array}{l}\text { Disposable income } \\
\text { (EUR) }\end{array}$ & 212.86 & 69.79 & 70.42 & 141.95 & 181.73 & 249.68 & 469.26 \\
\hline \multicolumn{8}{|l|}{2011} \\
\hline $\begin{array}{l}\text { Lowest necessary } \\
\text { net income (EUR) }\end{array}$ & 382.15 & 290.49 & 285.62 & 327.95 & 377.67 & 411.06 & 551.98 \\
\hline $\begin{array}{l}\text { Disposable income } \\
\text { (EUR) }\end{array}$ & 285.7 & 88.59 & 96.85 & 194.31 & 257.22 & 337.89 & 620.26 \\
\hline
\end{tabular}




\begin{tabular}{|c|c|c|c|c|c|c|c|}
\hline \multicolumn{8}{|l|}{2012} \\
\hline $\begin{array}{l}\text { Lowest necessary } \\
\text { net income (EUR) }\end{array}$ & 398.97 & 301.87 & 284.12 & 338.17 & 377.93 & 448.7 & 588.11 \\
\hline $\begin{array}{l}\text { Disposable income } \\
\text { (EUR) }\end{array}$ & 304.51 & 100.98 & 104.51 & 199.09 & 259.78 & 351.55 & 681.25 \\
\hline \multicolumn{8}{|l|}{2013} \\
\hline $\begin{array}{l}\text { Lowest necessary } \\
\text { net income (EUR) }\end{array}$ & 431.03 & 330.57 & 307.24 & 385.76 & 396.77 & 479.81 & 625.78 \\
\hline $\begin{array}{l}\text { Disposable income } \\
\text { (EUR) }\end{array}$ & 319.9 & 109.94 & 111.88 & 208.63 & 272.1 & 371.99 & 701.33 \\
\hline \multicolumn{8}{|l|}{2014} \\
\hline $\begin{array}{l}\text { Lowest necessary } \\
\text { net income (EUR) }\end{array}$ & 452.39 & 343.7 & 318.03 & 388.86 & 444.91 & 489.65 & 658.29 \\
\hline $\begin{array}{l}\text { Disposable income } \\
\text { (EUR) }\end{array}$ & 353.99 & 130.02 & 124.93 & 227.58 & 295.01 & 412.66 & 779.67 \\
\hline \multicolumn{8}{|l|}{2015} \\
\hline $\begin{array}{l}\text { Lowest necessary } \\
\text { net income (EUR) }\end{array}$ & 482.71 & 365.93 & 339.12 & 406.94 & 459.36 & 532.05 & 718.26 \\
\hline $\begin{array}{l}\text { Disposable income } \\
\text { (EUR) }\end{array}$ & 386.91 & 147.83 & 135.15 & 245.13 & 317.36 & 449.16 & 847.02 \\
\hline \multicolumn{8}{|l|}{2016} \\
\hline $\begin{array}{l}\text { Lowest necessary } \\
\text { net income (EUR) }\end{array}$ & 509.79 & 389.4 & 358.63 & 436.03 & 486.48 & 566.48 & 724.34 \\
\hline $\begin{array}{l}\text { Disposable income } \\
\text { (EUR) }\end{array}$ & 416.5 & 165.9 & 149.51 & 256.89 & 340.16 & 483.31 & 895.6 \\
\hline \multicolumn{8}{|l|}{2017} \\
\hline $\begin{array}{l}\text { Lowest necessary } \\
\text { net income (EUR) }\end{array}$ & 509.34 & 401.89 & 359.81 & 445.64 & 493.57 & 564.76 & 710.51 \\
\hline $\begin{array}{l}\text { Disposable income } \\
\text { (EUR) }\end{array}$ & 437.11 & 172.04 & 153.71 & 266.14 & 359.5 & 514.33 & 941.57 \\
\hline \multicolumn{8}{|l|}{2018} \\
\hline $\begin{array}{l}\text { Lowest necessary } \\
\text { net income (EUR) }\end{array}$ & 555.49 & 443.74 & 414.34 & 469.64 & 546.95 & 616.39 & 753.7 \\
\hline $\begin{array}{l}\text { Disposable income } \\
\text { (EUR) }\end{array}$ & 488.84 & 186.98 & 162.36 & 285.17 & 401.18 & 572.41 & $1,076.25$ \\
\hline
\end{tabular}

Source: Central Statistical Bureau of Latvia (CSB), 2020.

\section{Attitudes towards social issues}

Latvia is among the countries with a high human development index and has joined two "clubs" of developed states - the European Union and the OECD - thus with sufficiently high welfare indicators on a global scale. So, we shall also focus on the question raised by many researchers: why is social policy more generous in some prosperous democratic states compared to others, in a search for an explanation of why, in Latvia, Europeanization in the area of social policy is occurring in words but not exactly in deeds.

It is considered that two main factors influence generosity of social policy. One is ideology, the system of beliefs, culture and values existing in a particular society. The second is collective actors functioning within that society (Eppard et al., 2017). In the course of socialisation, we assume the mentality and values 
Table 2.1.5. Opinions of people in Latvia on the causes of poverty $(N=999)$

In your opinion, why do people live in poverty? Which of these four opinions is most compatible with yours?

\begin{tabular}{cccccc}
\hline $\begin{array}{c}\text { They have been } \\
\text { unlucky }\end{array}$ & $\begin{array}{c}\text { Because they } \\
\text { are lazy and lack } \\
\text { willpower }\end{array}$ & $\begin{array}{c}\text { Great injustice } \\
\text { exists in our } \\
\text { society }\end{array}$ & $\begin{array}{c}\text { It is an integral } \\
\text { part of progress }\end{array}$ & None of these & Hard to say/ NA \\
\hline $9.5 \%$ & $28.5 \%$ & $27.5 \%$ & $16.1 \%$ & $13.2 \%$ & $5.1 \%$ \\
\hline
\end{tabular}

Source: HDR Survey, 2020.

Table 2.1.6. Characteristics as to family composition of recipients of means-tested social assistance from local government, data for 2018

\begin{tabular}{|c|c|c|c|c|c|c|c|}
\hline 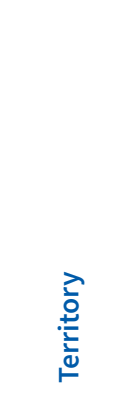 & 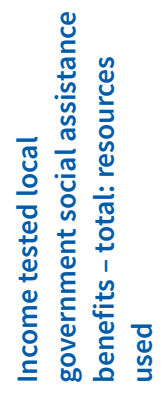 & 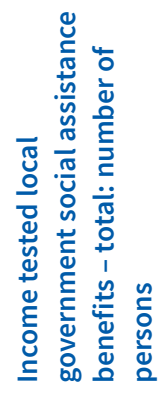 & 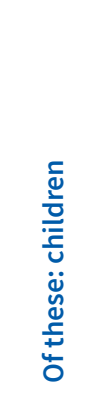 & 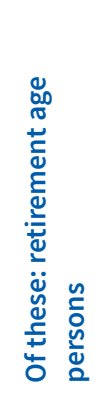 & 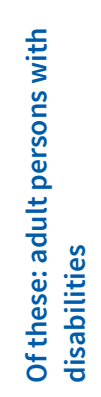 & 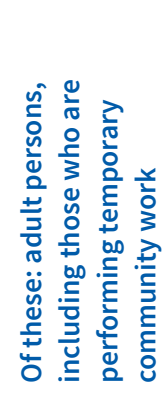 & 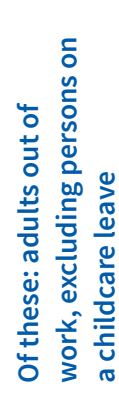 \\
\hline Cities: & $15,235,012$ & 53,277 & 8,670 & 25,479 & 6,962 & 4,560 & 7,700 \\
\hline Regions: & $10,181,073$ & 71,924 & 18,025 & 24,324 & 7,712 & 6,805 & 16,768 \\
\hline TOTAL & $25,416,085$ & 125,201 & 26,695 & 49,803 & 14,674 & 11,365 & 24,468 \\
\hline
\end{tabular}

Source: Labklājības ministrija (Ministry of Welfare) (2019). Valsts statistikas pārskatu kopsavilkums. Pārskati par sociālajiem pakalpojumiem un sociālo palīdzību pašvaldībā 2018. gadā.

of our society to the extent that it becomes impossible to think otherwise since that would be outside of what Noam Chomsky calls "the framework of thinkable thought” (Eppard et al., 2017, 10). For example, thinking that is tolerant of high poverty indicators and justifies income inequality as being normal in capitalist society and believes that everyone has an equal opportunity to achieve well-being by their own resources leads to hardening and embedding of inequality in society, which could be totally otherwise if thinking on poverty and inequality differed.

A survey conducted for the requirements of the Human Development Report shows that currently almost one-third of people in Latvia (28.5\%) consider that the main reason why people live in poverty is that they are lazy and are lacking in willpower. Similarly - again almost one-third of people in Latvia $(27.5 \%)$ believe that the main reason why people live in poverty is that society is not fair. True, almost one-fifth (13\%) do not subscribe to either of the explanations offered or have not made up their mind in this matter (5\%) (Table 2.1.5.).
The data may prove that the perception of the role of a person's willpower and work in creating their own wellbeing is becoming ever more consolidated in society. These answers to the question regarding the causes of poverty clearly show that society lacks an understanding of the structural causes of poverty that are built into society as a system. It is deeply alarming that almost one-third of the people in Latvia live under prejudice against the poor, blaming them for their own poverty. Undoubtedly, many individual cases allow discussion of a person's unwillingness to make the effort to increase their own welfare. However, taking into account that the indicators of people at risk of poverty before social transfers in Latvia are lower than on average in Europe but are higher after transfers (because the state invests in levelling income differences comparatively less than in other EU Member States), it is more difficult to assert that poverty is only a problem of individuals' laziness. Likewise, statistics on persons in Latvia who received means-tested social assistance from their local government in 2018 (thus including those who have been 
recognised as needy or disadvantaged), show that adult working-age persons who could, indeed, invest more effort in increasing their own welfare constitute only approximately one-fourth (Table 2.1.6.). Should children, seniors and persons with disabilities who receive benefits indeed be regarded as being poor because of their own laziness or lack of willpower? Research referred to earlier in this piece has also identified that Latvia is among the countries where parents' means determine the level of the next generation's welfare to a greater extent than their own efforts (UNDP, 2019).

At the same time, $89 \%$ of people in Latvia assess income differences as being too large, with $82 \%$ considering that it is the government's obligation to decrease income differences between those with high and low incomes. Moreover, this opinion is held by a large proportion of rural inhabitants compared to those living in Riga or other cities. Although almost one-third believe that people's laziness is to blame for their own poverty, only $12.8 \%$ believe that the government should spend less on benefits for the needy. People living in Riga are most generous with respect to benefits - only $7.2 \%$ believe that the government should spend less, whereas $79.7 \%$ do not hold this opinion.

In general, it can be concluded that inhabitants almost unanimously (some 89\%) negatively assess high income differences and expect government action to decrease these differences. Thus political actors - the Saeima and the Cabinet - are not acting in conformity with the views of the majority of people in Latvia. Presumably, people's attitude towards the issue of inequality might motivate decision-makers or exert pressure so that they would seriously consider it. The matter of poverty is more complicated. Although the majority of people do not hold the opinion that current governmental expenditure for supporting the poorest is too high (and statistics also show that this expenditure is among the lowest in the EU), the diversity of opinion as to the causes of poverty and the relatively high share of people who blame the poor themselves or who have no opinion on the matter reveals the need for more extensive discussion of structural and individual causes of poverty. European values and the aims declared in Latvia's development documents can be implemented only with strong support by society and pressure on decision-makers.

\section{Conclusions}

Today's attitudes and political decisions form tomorrow's quality of life. If we want to proceed in the direction of European social policy and achieve a situation where everyone in Latvia benefits from economic development, it is particularly important to adopt decisions that lead in this direction. If we wish to be a society with moderate income differences between people with high and low incomes and where parents' means do not determine their children's future opportunities it is vital to make decisions that ensure greater equality of opportunity. If we look at the opportunities and the future of the younger generation in Latvia, the current decisive indicator is whether a young person comes from a prosperous or a poor family, from Riga or a remote rural area. Social inclusion has for the first time been included as a separate line of activity in "Latvia's National Development Plan for 2021-2027", while equal opportunity for children, irrespective of a family's social status, has been advanced as a separate objective in the line of action titled "Strong families over generations". If decision-makers in the Saeima and the government find the political will to implement these aims in life and if civil society sees to it that this political commitment is met, then in the coming decade Latvia has the hope of experiencing significant Europeanization in resolving social issues - to significantly decrease the share of the population at risk of poverty, to decrease the income gap between Latvia's most prosperous and poorest, and to ensure the younger generation more equal opportunities to become shapers of their own life and prosperity.

\section{Main findings and most important tasks}

\section{Main findings}

Although social policy still remains in the competence of each Member State, since the turn of the millennium social issues have also been paid increasing attention on the political agenda of the EU. In Lisbon in 2008, the Council of the EU approved the open method of coordination (OMC) for the elimination of poverty and social exclusion. Europe's strategy for smart, sustainable and inclusive growth "Europe 2020" (2010) for the first time advanced reducing poverty as a strategic development aim. In 2017, at the Gothenburg Social Summit, the Member States agreed on the social rights pillar of the EU. However, in Latvia social matters have always been relegated to second place, as is disclosed by the low share of expenditure for social protection, as a result of which income inequality and the share of people in Latvia at risk of poverty is higher than average EU indicators. Until now, the political will to ensure social protection complying with human dignity and to align minimum income levels has been lacking. 


\section{Most important tasks}

Before social transfers, poverty indicators in Latvia are similar or lower compared to the other EU Member States. It would be important to ensure that they are also similar or lower than the EU average after social transfers. This means that the state must invest more resources in social protection. In the summer of 2020, three judgments by the Latvian Constitutional Court concern the incompatibility of minimum income levels with the principle of human dignity. The government will be forced to find the necessary resources to improve plans - elaborated in 2014 but regularly postponed - and to implement them in reality. 


\subsection{Opportunities and challenges of the Common Agricultural Policy for Latvia's rural areas}

\section{Aija Zobena}

\section{Introduction}

Discussions on agriculture and the place and role of rural areas in Latvia's past, present and future have not ceased since the 1990s, when Latvia regained independence and the process of large-scale transformation of socioeconomic processes started, leading to formation of a new political order and the economic life of society reoriented itself from the centralised system of economy of the Soviet state to market principles and a corresponding social structure. A romanticised perception of "Latvians as a nation of ploughmen" was replaced by a "flourishing economy based on the export of butter and bacon" soon after the restitution of land with "agriculture as a business" and "agriculture as a lifestyle", which still remains relevant thirty years after the system of collective farms collapsed, and consolidation of private property along with a market-based system of economy in the sector of agricultural production. The rhetoric of these discussions has changed but the juxtaposition of the diverse groups living and working in the countryside has remained unchanged.

What has changed in the discourse of rural development and agricultural production following Latvia's accession to the European Union (the EU), whose Common Agricultural Policy (CAP) not only requires a large part of the EU budget but is also the constant object of discussion between the Member States? In 2014-2020, the share of agriculture and cohesion expenditure in the EU budget constitutes approximately $70 \%$ of the total amount, while in 2020 some $39 \%$ is envisaged for the CAP and fisheries (European Commission, 2020). How has Europeanization impacted the structure of production resources in agriculture and the effectiveness of their use? What has changed in Latvia's rural life since accession to the EU? Financing of the "Rural Development Programme for 2014-2020" amounts to 1.5 billion EUR (Ministry of Agriculture, 2020). Have these resources been spent, appropriated, or invested in future growth?

\section{Rural development and agricultural production in the global context}

According to UN data, in 2007 alone the proportion of the urban population worldwide exceeded $50 \%$, and in many countries the majority of the population still lives in rural areas. The most recent available data suggest that in by 2018 some $55 \%$ of the global population are city dwellers (United Nations, 2019). In Latvia, approximately one-third of the population lives in rural areas (Figure 2.2.1.).

Processes of urbanisation, which accelerated with the development of industrial production, also affected the most remote corners of the globe only in the second

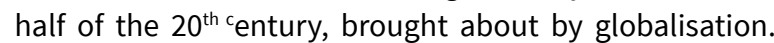
During this period, significant changes also occurred in the major developed economies. Although the proportion of the rural population in these countries decreased swiftly, for the majority of them agricultural production and forestry continued to be their occupation and source of income, so that agriculture was the object of research both for natural and social scientists - higher crop productivity and farmed animals, new production technologies and increasing economic effectiveness in the organisation of production. Stereotypes prevailed in society regarding rural life as a quiet and peaceful haven, still retaining a virgin natural environment, traditional values and backwardness in daily life, as well as limited accessibility of various services.

The situation changed in the last decades of the $20^{\text {th }}$ century with globalisation and a new level in intensifying agricultural production, which significantly broadened the range of problems related to rural life. Swift industrialisation began in the new developing states in South East Asia and Africa, with more people moving to cities in search of work and earnings. With a growing standard of living and demand for food, intensive development of agriculture also began in these countries. In the developed states, trends that are still ongoing appeared in rural development - formation of the agrifood and agri-environmental sector, agricultural production and food chains. Concerns about environmental conditions as well as interest in food quality and safety increased in society, causing a rapid increase in demand 


\section{Figure 2.2.1. Urban dwellers as a share of population in Latvia, Northern Europe, and Europe as a whole}

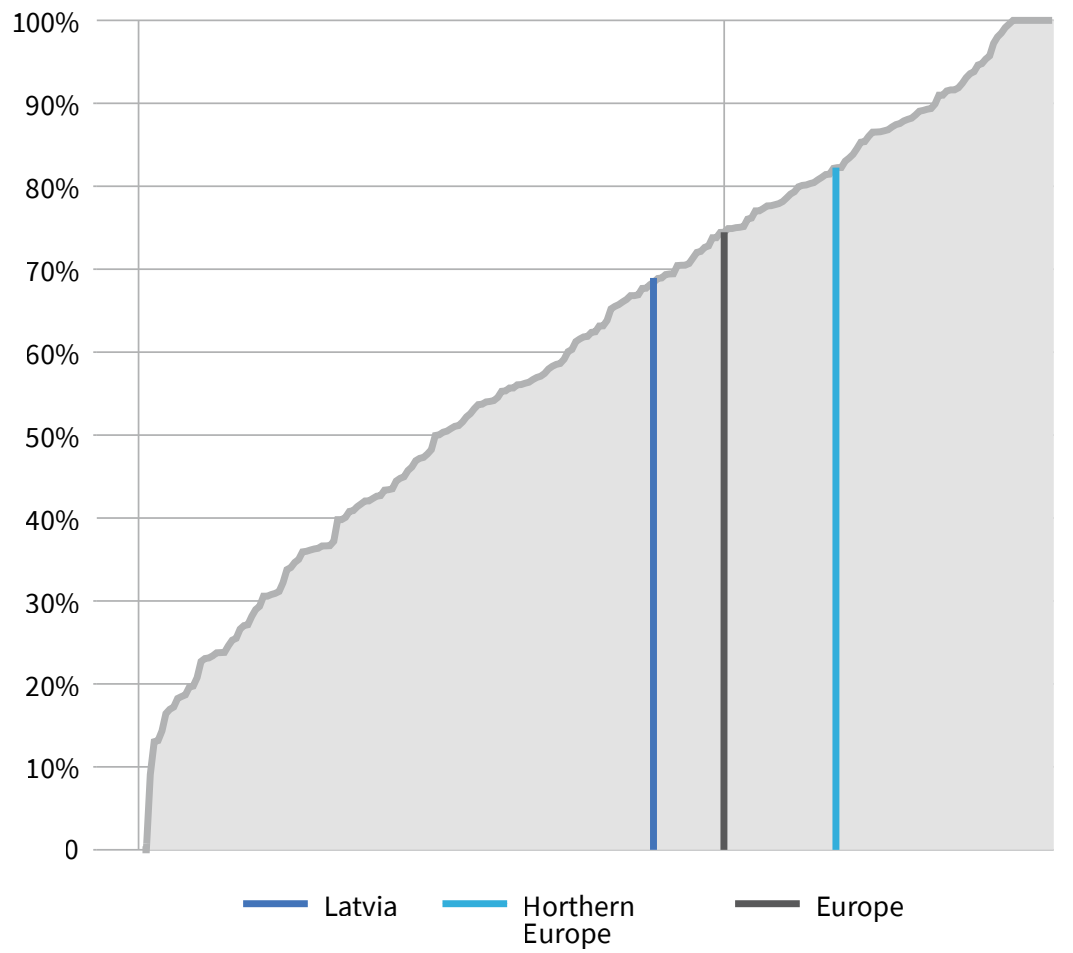

Source: https://population.un.org/wup/Country-Profiles/Plots/Latvia/ProportionUrbanAllCountries.svg

for eco-products, organic and environmentally-friendly products. Consumers' choice in food stores (and also in the area of other agricultural products) is increasingly linked to matters of fair trade, animal welfare, products of a specific geographical origin, such as wine and cheese, as well as protection of the environment and biological diversity (Busch, 2016). Although the peoples of the new EU Member States have low purchasing power and the environment is in relatively good condition following a decrease in agricultural production in the course of restructuring the agricultural production sector, nevertheless substantial changes occur in supply chains of agricultural food products (Gorton, White, 2007), including in Latvia.

In the developed states, the role of the agricultural sector in the overall economic structure has been decreasing over recent decades - the share of agriculture in gross national product is shrinking. Other agriculture-related sectors (for example, sales and service of agricultural machinery, processing of food and industrial crops, tourism services) are gaining significance in rural economic life, whereas the share of primary agricultural production - food and industrial crops - is decreasing. In short, changes are under way in the structure of farm income and land use as well as the structure of employment in rural areas. Diversification of farming income increases their sustainability because, alongside agricultural production, which is seasonal and exposed to risks such as changing weather conditions, plant and animal diseases, and pests, employment opportunities are developing that provide a stable year-round income - for example, artisanal food production/processing, crafts, revival of traditional foods - and facilitating development of short food chains. Distance working is creating new employment opportunities. Of late, such innovative forms of farming diversification that simultaneously offer solutions to several rural development problems are becoming more widespread in many European countries - for instance, social care farms. In the context of rural development, this is a promising type of social entrepreneurship which could offer households a stable income throughout the year and, at the same time, offer social services, which are in demand in an ageing society and whose accessibility is particularly relevant in rural regions (Dessein, Bock and de Krom, 2013). The share of people who choose the countryside as an exclusive place of residence where the daily comfort provided by modern technologies can be combined with being close to nature, rural peace and quiet, is gradually increasing. The possibilities of remote work and a developed road and transport infrastructure enable combining life in the countryside with interesting work and good income in sectors unrelated to agriculture and also allow combining life in the countryside with working in the city. This is indirectly evidenced by the rapid increase in the number of people living in Greater Riga, 
and the flow of cars towards Riga on week-day mornings and back to the countryside in the evenings. Many people in Latvia have a holiday home or a summer house in the countryside.

To draw attention to the fact that not only production of goods but also other socially significant activities take place in rural areas, at the turn of the millennium social scientists offered the concept of multifunctional agriculture. Thus economic and social activities in rural areas should be examined from several, much broader perspectives. Agriculture and forestry produce not only food and raw materials such as biomass or fibre but also create diverse other benefits important for society - national food sovereignty, food safety, preservation of historical landscapes and environment, care for biological diversity, limiting the threat of floods, offering possibilities for tourism and recreation, maintaining populated rural areas, and creating opportunities for new types of entrepreneurship in rural areas (van Huyienbroek, Durand, 2003). The concept of multifunctional agriculture is linked to the multidisciplinary approach to understanding rural life - both from the perspective of economy/ agricultural economy, agricultural science, economic and social geography as well as rural sociology.

During recent decades, the social and political context of rural development has been changing. With the decreasing share of people linked to primary agricultural production, rural communities are becoming increasingly heterogeneous. Social inequality of the rural population is increasing - agricultural production resources (land and capital) are concentrated in a small part of holdings (Table 2.2.1.), many rural people are losing opportunities for employment and earnings and are forced to leave their home because employment opportunities in other sectors are limited. The rapid and uneven urbanisation of areas adjacent to cities is often manifested as segregation of the local inhabitants of those areas from recent incomers, deficiencies in service and utility infrastructure, and fragmentation of spatial structures.

Table 2.2.1. Grouping of holdings according to the area of agricultural land (thousand ha)

\begin{tabular}{|c|c|c|c|c|c|c|c|c|c|c|c|c|}
\hline & \multicolumn{4}{|c|}{2010} & \multicolumn{4}{|c|}{2013} & \multicolumn{4}{|c|}{2016} \\
\hline & 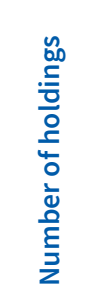 & 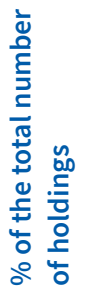 & 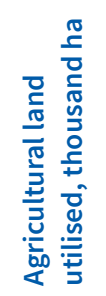 & 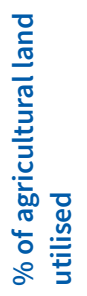 & 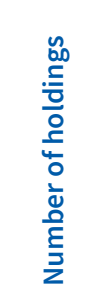 & 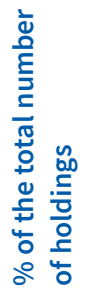 & 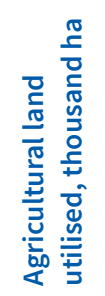 & 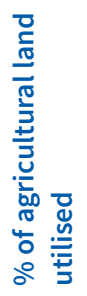 & 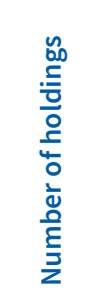 & 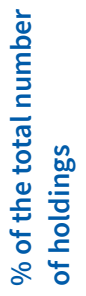 & 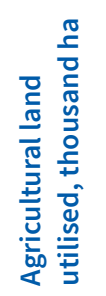 & 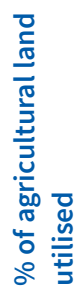 \\
\hline Total & 83,386 & 100.0 & $1,796.3$ & 100.0 & 81,796 & 100.0 & $1,877.7$ & 100.0 & 69,933 & 100.0 & $1,930.8$ & 100.0 \\
\hline below 0.9 & 4,216 & 5.1 & 1.7 & 0.1 & 7,146 & 8.7 & 3.1 & 0.2 & 5,865 & 8.4 & 2.5 & 0.1 \\
\hline $1.0-2.4$ & 8,424 & 10.1 & 14.4 & 0.8 & 9,039 & 11.1 & 13.2 & 0.7 & 8,295 & 11.9 & 13.1 & 0.7 \\
\hline $2.5-4.9$ & 15,338 & 18.4 & 56.4 & 3.1 & 12,413 & 15.2 & 39.1 & 2.1 & 10,143 & 14.5 & 37.6 & 2.0 \\
\hline $5.0-9.9$ & 22,662 & 27.2 & 161.6 & 9.0 & 15,535 & 19.0 & 96.5 & 5.1 & 15,878 & 22.7 & 115.1 & 6.0 \\
\hline $10.0-19.9$ & 17,496 & 21.0 & 243.0 & 13.5 & 19,115 & 23.4 & 220.1 & 11.7 & 14,570 & 20.8 & 203.4 & 10.5 \\
\hline $20.0-29.9$ & 5,669 & 6.8 & 137.1 & 7.6 & 6,532 & 8.0 & 135.0 & 7.2 & 4,990 & 7.1 & 120.9 & 6.3 \\
\hline $30.0-39.9$ & 2,484 & 3.0 & 85.2 & 4.7 & 3,200 & 3.9 & 95.5 & 5.1 & 2,380 & 3.4 & 81.9 & 4.2 \\
\hline $40.0-49.9$ & 1,472 & 1.8 & 65.4 & 3.6 & 1,832 & 2.2 & 73.5 & 3.9 & 1,380 & 2.0 & 61.5 & 3.2 \\
\hline $50.0-99.9$ & 2739 & 3.3 & 187.7 & 10.4 & 3,095 & 3.8 & 194.3 & 10.3 & 2,887 & 4.1 & 201.8 & 10.5 \\
\hline 100.0-199.9 & 1,387 & 1.7 & 192.0 & 10.7 & 1,540 & 1.9 & 202.1 & 10.8 & 1,623 & 2.3 & 226.4 & 11.7 \\
\hline $200.0-499.9$ & 781 & 0.9 & 240.7 & 13.4 & 1,010 & 1.2 & 299.4 & 15.9 & 1,100 & 1.6 & 339.1 & 17.6 \\
\hline 500.0 and more & 402 & 0.5 & 411.1 & 22.9 & 491 & 0.6 & 505.8 & 26.9 & 524 & 0.8 & 527.4 & 27.3 \\
\hline $\begin{array}{l}\text { Without utilised } \\
\text { agricultural } \\
\text { land }\end{array}$ & 316 & 0.4 & $x$ & $x$ & 847 & 1.0 & $x$ & $x$ & 297 & 0.4 & $x$ & $x$ \\
\hline
\end{tabular}

Source: Central Statistical Bureau of Latvia (CSB). 
If in rural areas, alongside production of goods (agricultural products) the common good - such as environmental and biological diversity and opportunities for recreation - is created, a valid question arises: who finances it all? Public financing or the market? Does the state or the buyer of food products pay for the common good created in rural areas? The CAP envisages financial support not only for agricultural production but also for rural development and preservation of environmental and bio-diversity.

\section{The EU Common Agricultural Policy}

With accession to the EU, Latvia joined the CAP (see Box 2.2.1.). Since its establishment in 1962, the CAP has undergone significant changes. It developed at the time when Europe was still recovering from the devastation brought on by the Second World War, cities were fast-growing, the share of the rural population was decreasing and the need to intensify agricultural production came to the fore in order to satisfy rapidly growing demand with fewer resources. At the turn of the 21st century, Europe faced new challenges: intensifying global competition in the market for agricultural products, biotechnologies and changes in the discourse on rural development and agriculture - all requiring a response.

Alongside development of agricultural production, the CAP also defines the aims of rural development (in a broader sense), comprising preservation of the environment and the cultural-historical landscape, and decreasing social inequality (Figure 2.2.2.). The CAP defines the strategic aims for rural and agricultural development, as defined in the national rural development programme of each Member State in accordance with its particular situation. The economic and structural context of agriculture in the Member States is still highly heterogeneous, so that setting unified quantitatively measurable development indicators would not make great sense. For example, low value of income from agriculture in the Netherlands would be extremely high in the Bulgarian context.

Each Member State draws up its rural development programme in compliance with the aims defined in the CAP and the strategies recommended for achieving them. Methodological assistance in drawing up national rural development programmes (RDP) is provided by cooperation between Member State research institutions within the European Rural Development Network (ERDN, see http://erdn.eu/), which has been operating since 2002, where Latvia is represented by the Institute of Agricultural Resources and Economics (IARE) (https:// www.arei.lv/en). The IARE Department for Evaluation of Rural Development (DERD), which started operations in 2009 on the basis of delegation by the Ministry of Agriculture (MA), assesses Latvia's RDP programme and the Operational Fisheries Programme (OPF). RDP is approved by the European Commission. Various rural and agricultural development interest groups, represented by diverse non-governmental organisations, are involved in drafting RDP. The most influential among these is the Farmers' Parliament (ZSA) - a non-governmental organisation of agricultural and horticultural produce producers, established in 1999. Its 800 members represent the largest agricultural production companies (https://zemniekusaeima.lv/). Farmers' Parliament is a strong organisation, which lobbies the interests of large agricultural producers. The second largest farmers' organisation is the Latvian Agricultural Organization Cooperation Council (LAOCC), which unites the non-governmental organisations of producing and processing companies of national scope, covering the whole of Latvia and all sectors of production. LAOCC has been operating since 2000 and currently unites

\section{Box 2.2.1.}

\section{The EU Common Agricultural Policy}

The EU Common Agricultural Policy (CAP), launched in 1962, is a partnership between agriculture and society, Europe and its farmers.

It aims to:

- support farmers and improve agricultural productivity, ensuring a stable supply of affordable food;

- safeguard European Union farmers to make a reasonable living;

- help tackle climate change and sustainable management of natural resources;

- maintain rural areas and landscapes across the EU;

- keep the rural economy alive by promoting jobs in farming, agri-food industries and associated sectors.

The CAP is a common policy for all EU countries. It is managed and funded at European level from the resources of the EU budget.

Source: https://ec.europa.eu/info/food-farming-fisheries/key-policies/common-agricultural-policy/cap-glance_lv 


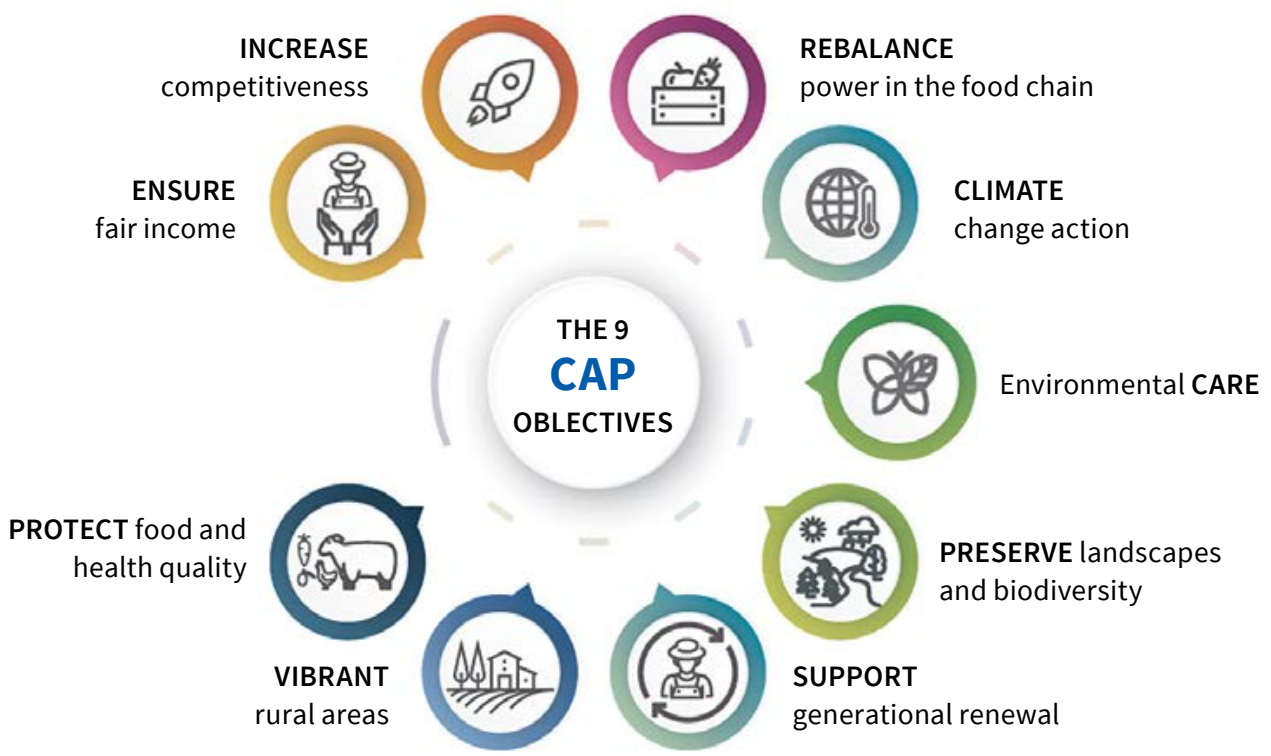

Source: https://ec.europa.eu/info/food-farming-fisheries/key-policies/common-agricultural-policy/future-cap_en

59 producers' organisations (http://www.losp.lv/). It is an umbrella organisation, uniting organisations of agricultural production and processing companies and rural partnerships. The composition of LOSP is heterogeneous, its members are both relatively large and influential organisations and small associations, on whose activities information is hard to find. For example, the Latvian Organic Agriculture Association (LOAA) (http://www.lbla.lv/) has international cooperation partners and is involved in international organic agriculture organisations. LOAA often expresses opinions that are contrary to the interests of producers that use conventional technologies. The Latvian Rural Forum (https://laukuforums.lv/lv/) is a large and influential organisation. However, not all rural development target groups are able to unite in non-governmental organisations (NGOs) to express their needs.

\section{Rural development in Latvia after EU accession}

In the context of the EU CAP, the whole of Latvia is considered to be a rural area, except for the cities and regional administrative centres (in line with the administrative-territorial reform of 2009).

Although the rural population has decreased in absolute numbers since 2004, in general the rural population in Latvia is proportionally rather stable, showing a decrease from $32.2 \%$ at the beginning of 2004 to $31.5 \%$ (Figure 2.2.3.). Pursuant to the Law on Administrative
Territories and Populated Places, promulgated in June 2020 by the President (https://ikumi.lv/ta/id/315654-administrativo-teritoriju-un-apdzivoto-vietu-likums), urban dwellers in terms of both numbers and share of the total will increase rapidly because the densely populated area of Riga Region (Pierīga) will be granted city status. With the decreasing population in Latvia in general, the density of population is also falling. This seriously hinders possibilities to ensure accessibility of various social services in sparsely populated areas.

The share of the urban and rural population incompletely reflects the social inequality that exists in Latvia and continues to deepen if comparing the central part of the country with the periphery. Social scientists point to significant regional differences in terms of employment, risk of poverty, economic tension, and accessibility of various services (Bela et al., 2018). Trends in the domestic migration of the population characterise this inequality quite well. The population is decreasing in all regions, except Riga Region. Residents of the capital city often move to Pierīga (Table 2.2.2). Inhabitants leave places with limited employment opportunities and where qualitative education is unavailable for children.

The costs of education, health and social care services in less populated districts cause a disproportionate burden on the state budget, whereas the poor quality of transport infrastructure and underdeveloped public transport restrict the possibilities of residents in areas that are more distant from large towns to use those services in places where they are available in higher quality. Unavailability of qualitative education 


\section{Figure 2.2.3. Latvia: number of people in rural areas/ cities at the beginning of 2020}

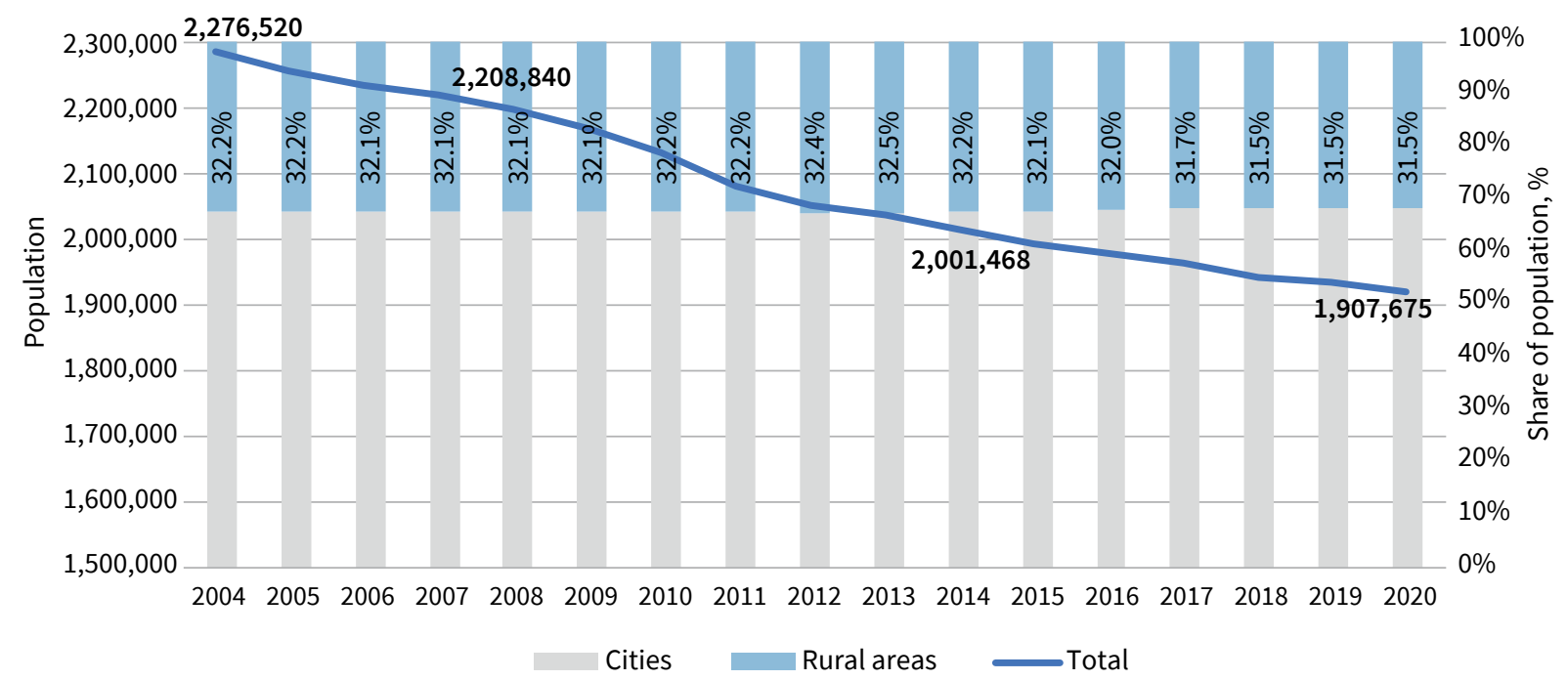

Source: Central Statistical Bureau of Latvia (CSB).

Table 2.2.2. Balance of long-term migration of population: regions, cities and districts

\begin{tabular}{lcc}
\hline & 2018 & 2019 \\
\hline Rīga Region & $-2,934$ & $-2,548$ \\
\hline Pierīga (Greater Riga) Region & 3,588 & 4,007 \\
\hline Vidzeme Region & $-1,258$ & -924 \\
\hline Kurzeme Region & $-1,372$ & $-1,432$ \\
\hline Zemgale Region & $-1,061$ & -825 \\
\hline Latgale Region & $-1,868$ & $-1,638$ \\
\hline
\end{tabular}

Source: Central Statistical Bureau of Latvia (CSB).

in the periphery can cause the risk of deepening social inequality between the population of the centre and the periphery in the future.

Unfavourable changes in the demographic structure of the population (ageing population, mortality exceeding the birth rate) also have a pronouncedly regional nature. Migration substantially influences the decreasing numbers of the working-age population. In Latvia, the backbone of rural economic life is still shaped by traditional sectors - primary agricultural production, forestry and wood processing, and rural tourism. Notwithstanding the rapid increase in levels of production following accession to the EU and CAP support, OECD experts conclude that, in Latvia, the largest part in the export of agricultural and food products consists of raw materials or products with low added value, indicative of an ineffective value chain, insufficient processing capacity and poor supply chain organisation (OECD, 2019, 23).

Although primary agricultural production does not require large human resources and is seasonal in nature, the availability of a qualified labour force is an important condition for it to function normally. This leads to a vicious circle of a kind - to attract a highly qualified labour force for the development of production in more remote places, good remuneration is not enough - a good standard of living should be ensured to people, and accessibility of various services, which in turn can be achieved only in densely populated areas. The chain of causalities closes. Concentration of production resources, primarily land, in large holdings and the related intensification of production, on the one 
hand creates well-paid and qualified workplaces but, on the other hand, diminishes employment possibilities in rural areas since the number of jobs decreases, which is not followed by the creation of new jobs in another sector. Possibly, RDP measures for creating new jobs and supporting entrepreneurship are not always effective enough. With decreasing employment opportunities in agriculture, rural inhabitants should be looking for earning possibilities in other sectors.

Employment opportunities in sectors unrelated to agriculture in Latvia's rural areas are not extensive enough. This is also reflected by income inequality between regions. In the regional cross-section, income differences are quite considerable. The minimum salary in Latvia (on 1 January 2020 - EUR 430), compared to the other EU Member States with a state-defined minimum, is one of the lowest. At the beginning of 2020, only Bulgaria had a lower indicator. Compared to 2019, at the beginning of 2020 the minimum salary increased in all EU Member States, except Latvia, Spain, Belgium, and Ireland. Poland had the largest increase in the minimum salary in the European Union - 16.8\%, reaching EUR 611 at the beginning of 2019. In Lithuania, the minimum salary increased to EUR 607 (9.4\%) and to EUR 584 (8.1\%) in Estonia (CSB 2020, 27). Although the trend can be observed of inhabitants moving to Pierīga Region, jobs remain in the capital city. The level of salaries differs radically in Riga and Pierīga Region, where gross average remuneration exceeds EUR 1,200, whereas in Latgale region it is the lowest - on average, approximately EUR 750 , and in other regions - above EUR 850. In rural areas, the disposable income per one member of the household in 2018 was $16 \%$ lower than in cities (CSB 2020, 28).

Measures for knowledge transfer and informative measures of RDP, implemented in 2014-2020, and activities held with the LEADER approach to community-led local development (CLLD) aim at fostering social inclusion, decreasing the risks of poverty, and promoting territorial cohesion. LEADER/CLLD measures, starting with drawing up a local development strategy followed up by implementation, make the local community more active, form a common area of information and cooperation, encourage and learn how to write projects, increase the administrative capacity of local action groups (LAG) needed to organise and foster planning and implementation of development processes in their communities, including the range of attention of persons in need of assistance (AREI, 2019, 127). CLLD strategy, in conformity with LEADER methodology, was oriented towards defining and meeting the needs of the local community, combining a variety of available financing possibilities. This means that needs should not be oriented only towards the criteria for attracting financing from the European agricultural fund for rural development (EAFRD) and/ or the European Maritime and Fisheries Fund (EMFF), even more - they should not be subordinated to the terms of these two funds. In the previous
CAP programming periods, these were the main sources of financing for rural development. In view of the above, it would be logical that the basis for strategies - identifying area needs and defining development aims is created by identifying and prioritising the needs of the local community and advancing the meeting of these needs as the local development aim. Thus, identifying the local community's needs is primary but attracting financing from various sources (including EAFRD and EMFF) is only a means of attaining the aims defined in the strategy. Therefore CLLD should consist of two parts - analysis of the development needs of the local area and defining development aims, and a strategic plan for achieving those aims. Moreover, this plan should envisage attracting financing from a variety of sources (not only EAFRD and EMFF). These principles are not always implemented in CLLD strategies. In regions with a large share of smallholdings, CLLD strategies seldom refer to such development possibilities as collaboration, cooperation, development of short food chains and home production, which are identified as development opportunities by researchers in this area (Melece, 2018). Analysis of LAG (local action groups') understanding of the target groups of CLLD strategies shows that such concepts as "target groups", "stakeholders", "beneficiaries" are often not differentiated between. In their activities, VRG are more focused on potential project applicants - entrepreneurs, local NGOs, local governments. Many LAG representatives have an incomplete understanding of the concepts "territorial cohesion", "social inclusion" (AREI, 2018).

\section{Conclusions}

Following accession to the EU, in Latvia a major part of the support for agriculture and rural development is provided within the framework of the CAP. After the decline in production experienced in the 1990s, a significant increase in the level of production has been achieved within a comparatively short period, significant structural changes have taken place - large and export-capable rural holdings have appeared. Although the level of production and export has increased, a major part of exported products remains with low added value.

However, concentration of production resources and intensification also brought with them undesirable social effects. Rapid segregation of inhabitants is observed in rural districts, which promotes negative demographic processes. Unable to find work and sustenance in the countryside, people leave for the cities, some even leaving the country altogether. The emptying of the countryside has a negative impact on social development - accessibility of education, health, and social care services. This poses risks for sustainable, innovation-based rural development in the future. 


\section{Main findings and most important tasks}

\section{Main findings}

Europeanization in the area of rural and regional development cannot be assessed unequivocally. With integration into the CAP, decision-making in the area of rural development policy has changed. It has significantly expanded the understanding of what rural development and agricultural production are, promoted the development of a new model for policymaking based on aligning the interests and visions of development of the various groups involved on a national level, within the unified framework of the CAP. Significant resources have been invested in developing Latvia's potential for agricultural production. On the other hand, not all rural development target groups have so far been able to effectively express and defend their interests, using the opportunities granted by integration in the European Union.

\section{Most important tasks}

Policymakers and researchers should define evidence-based strategic aims of rural and agricultural development that would take into account the advantages and opportunities of Latvia's natural environment and climate to create products with higher added value, seeking appropriate export niches for them. Support for participation by diverse social groups in the development of rural and regional development policy should be reinforced both on the local government and national level. 


\subsection{Not every tree in the forest stands tall: ${ }^{1}$ Europeanization of the media environment}

\section{Klinta Ločmele}

\section{Introduction}

In a simple and figurative simile, the European Union (EU) is like a garden with 27 trees, each symbolising a Member State. Tall pines are found there as well as comparatively young growth, not yet fully developed. This Chapter focuses on compliance in Latvia's media environment with EU standards, both during the accession negotiations and today. Representation of EU topics in the national daily press is also examined - the most frequent topics and where they stand on the agenda. Attention is also paid to the audience the extent to which people in Latvia are interested in obtaining information about EU topics from the media. In the conclusion, the Chapter suggests that although, in general, processes in the Latvian media environment meet EU expectations, de-Europeanization is occurring in Latvia with respect to some indicators.

The concept of Europeanization has several explanations. The simplest approach understands the expression as transposition of EU directives and regulations on the national level. However, this understanding is broadened to include taking over EU values, discourses, and identity (Schimmelfennig, 2010). The formal beginning of Europeanization of Latvia's media environment can be traced to 1995, when Latvia expressed the wish to become one of the EU Member States. For the accession negotiations to succeed, the aim was set to adopt EU norms in regulation of the media environment.

By the mid-1990s, the media environment had undergone many changes - developing an understanding of how to work and survive financially in the post-Soviet period when the state media became private companies and faced competition: the new market players. Strong commercial radio stations and TV programmes emerged, while the public media saw their audience dwindling. Journalism itself had not yet completely found a new identity. It is important to underscore the spread of professional standards of journalism of the Western democracies, which, to a large extent, happened thanks to the example set by the newspaper Diena and NTV 5 news programmes (Brikše, 2016). However, media researcher Inta Brikše characterised this period as follows: "a code of ethics for the media, accepted by the entire professional environment, has not yet appeared in Latvia. In situations that require solidarity of the professional environment to defend freedom of speech and of the press, unfortunately, the corporate interests of media editors and owners appear instead of journalists' opinions" (Brikše, 2016). She pointed to the Radio and Television Law, adopted in 1995, as one of the most qualitative trends in the development of Latvia's information environment since it was of great significance in aligning the system and the electronic media market (Brikše, 2016; Brikše 2010). As we shall see, this was a key regulatory enactment, transposing EU requirements with respect to regulation of television. This Chapter proceeds to analyse Europeanization of the media from three perspectives - media policy, media content, and audience.

\section{Europeanization of media policy}

During Latvia's negotiations for accession to the EU, media issues were predominantly understood as topics applicable to television as one media type. These were examined under the title "Audio-visual sector", together with the cinema. In order for Latvia as a candidate country to accede to the EU, it had to align Latvian legal acts with EU legal acts in the audio-visual sector and to implement the "TV without Frontiers" directive. The Ministry of Foreign Affairs at the time, reporting on the outcome of the accession negotiations, noted that "in the main, legal norms have been harmonised with EU requirements, Changes are being made to improve and develop operation of the National Radio and Television Council" (Foreign Ministry, 2004a). Benefits were listed: the share of European films, in particular the most recent, would increase on Latvian television. Uniform

\footnotetext{
1 A Latvian proverb.
} 
advertising standards would be introduced, for example with respect to the amount, form and use of advertising but also with respect to an advertising ban on forbidden goods - tobacco, alcohol, and medicines. Possible downsides are also indicated, estimating that the costs of television broadcasting organisations were likely to increase. This would be linked to the promotion of distribution of European works (which are more expensive compared, for instance, to works produced in the USA or South America) - in its programming a broadcaster must reserve at least $51 \%$ of its airtime for showing European works. A smaller share of series produced in Russia, the USA and Latin America could be seen as a loss for fans of these films and series (Foreign Ministry, 2004a).

In 1999, the negotiating position of the Republic of Latvia noted that some of the amendments to the Radio and Television Law that had been made to introduce the European Community directive in the audio-visual sector would enter into effect on 17 November 1999 (Foreign Ministry, 2004b). Examination of the Radio and Television Law, which is no longer current, reveals that, on the set date, several advertising norms entered into force - the provision that broadcasters were responsible for placing ads or teleshops in a programme or show in compliance with the law, while announcements of public importance that had been distributed free of charge and invitations to engage in charity were not considered to be advertising. The provision that "[c]ommercials, except for self-promotion, and teleshops may not use the images or recorded voices of persons who regularly anchor news or current affairs programmes" is also important (Latvian Parliament, 1995). Prohibition of teleshops for medicines and pharmaceutical products was added to the Radio and Television Law (Latvian Parliament, 1995). At the time, Latvia promised that possible deficiencies in Latvian legal acts would be eliminated by 2000 , enabling the country to participate in the European Community audio-visual programme Media 3, which was launched a year later (Foreign Ministry, 2004b). Likewise, a promise was made to improve the operations of the National Radio and Television Council, if necessary, in accordance with the requirements of the European Community.

Currently, the requirements that candidate countries must meet in the area of the media are included in Section 10 of the negotiations on "Information Society and Media" (comprising specific requirements as to electronic communication, information society services - in particular in the area of e-commerce as well as restricted-access services and audio-visual services) (European Commission, 2019a). Also assessed is whether the country is able to meet the criteria in one of the transversal policy issues - "freedom of the media and speech" - which the EU has marked as one of the main indicators for a candidate country's readiness to become part of the EU. Political pressure on the media, economic issues (media concentration), violence against journalists, and self-censorship are among the topics that hinder the accession of some candidate countries, such as Turkey, to the European Union (European Commission, 2019b; Yilmaz, 2016). An opinion exists that stricter criteria regarding freedom of speech and the media should be set for a candidate country's accession to the EU (Dunham, 2014).

The indicators for freedom of the media advanced by the EU have been met in Latvia, although risks can be observed in the implementation of some of the criteria. The drafting and adoption of "Mass Media Policy Guidelines of Latvia, 2016-2020" and the action plan for their implementation by the Cabinet in 2016 was an important factor with respect to a benevolent legal, regulatory and political environment for freedom of speech and the existence of the media. These include five main courses of action: 1 ) diversity of the media environment; 2) quality and accountability of the media environment; 3) education of professionals in the media sector; 4) media literacy; 5) securitability of the media environment (Cabinet of Ministers, 2016). With the Media Support Foundation starting its operations in

\section{Box 2.3.1.}

\section{Aims for freedom of the media advanced by the EU}

- a benevolent legal, regulatory and political environment for freedom of speech and the existence of the media;

- media representatives (owners, editors) assume responsibility for improved internal management and content production;

- media are resilient against external pressure;

- audience trust in the mass media increases;

- qualitative and reliable investigative journalism is available to the audience;

- representative professional organisations of the mass media and journalists are able to assume responsibility for sectoral issues in dialogue with public institutions and to provide services to their members. 
Figure 2.3.1. Ranking of the Baltic States in the press freedom index of the organisation Reporters Without Borders (2013-2020)

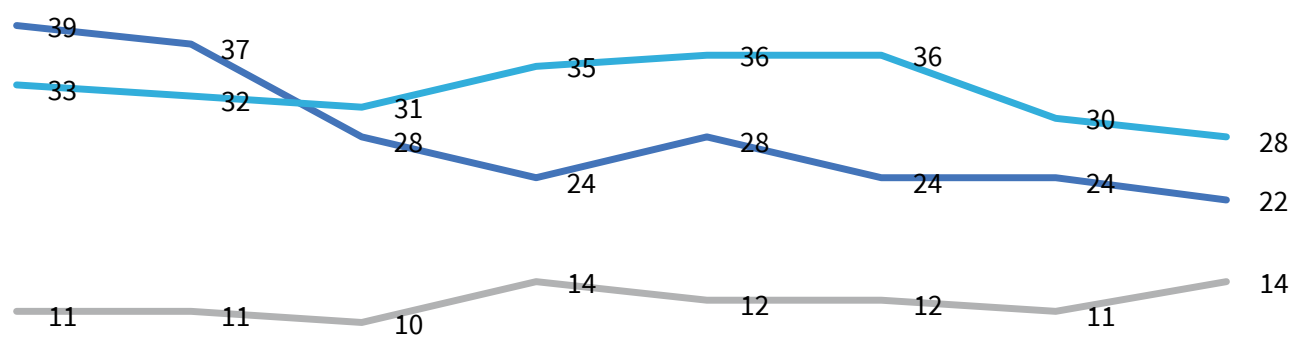

$\begin{array}{llllllll}2013 & 2014 & 2015 & 2016 & 2017 & 2018 & 2019\end{array}$

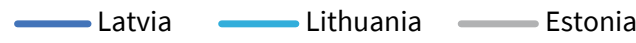

The higher the ranking in the index, the better the assessment of conditions in the country for the existence of freedom of speech (i.e., the situation in Latvia has improved since 2013).

Source: Reporters Without Borders.

2017, Latvia's media for the first time had the possibility to compete for resources of the Latvian state budget to create content of public importance. However, as regards the legal environment, adoption of new regulation and management of the public media was long delayed. On 19 November 2020, discussions that had lasted for several years concluded with the Saeima adopting the Law on Public Media and Management Thereof. This defines the strategic aim of the public electronic mass media, their legal status, operations, and basic principles of their financing, management and supervision. Although already envisaged by amendments to the Electronic Mass Media Law in the summer of 2018 that, as of January 2021, the public media would leave the advertising market, clarity on this issue was achieved only in the autumn of 2020 because the public media had to be compensated for unearned revenue. Because of this uncertainty, it was hard for the public media to plan their future work (Ministry of Culture, 2018; Kupčs, 2020; Līcīte, Dēvica, 2020, Latvian Parliament, 2020).

In Latvia, freedom of speech is guaranteed by Article 100 of the Satversme: "Everyone has the right to freedom of expression, which includes the right to freely receive, keep and distribute information and to express his or her views. Censorship is prohibited." (Constitutional Assembly, 1922) This right is once again reinforced in the law "On the Press and Other Mass Media", which stipulates that "the aim of this Law is to protect the right to freedom of speech, enshrined in the Satversme of the Republic of Latvia. Censorship of the press and other mass media shall not be allowed" (Supreme Council, 1990).

Summarising information on the situation with respect to freedom of speech in 180 countries, the international organisation Reporters Without Borders in 2020 ranked Latvia at 22, which represents a rise in the ranking and an improvement in conditions (in 2013 Latvia was ranked 39) (Reporters Without Borders, 2020).

In the press freedom index from 2013 to 2019, Latvia experienced both rise and fall; however, the general trend is moving upwards: from the lowest indicator - a score of 22.8 in 2013 - to 19.53 in 2019. (Johnson, 2020). Each year a new assessment is prepared, and the position attained can be lost with deteriorating conditions for freedom of speech in the country, for example if politicians start exerting pressure on the media or journalists are threatened. It cannot be asserted that Latvia's indicator has improved thanks to EU support for the media; to a large extent, this depends on the policy of each state and events in the media environment in any particular year. However, high EU standards with respect to freedom of speech and the media might be a counterargument against establishing any potential restrictions.

In contrast to Latvia's improved position with respect to freedom of the press, audience trust in the media is decreasing. Eurobarometer research conducted in November 2017 shows that since the spring of 2017 distrust in the media had increased by five per cent, reaching $35 \%$. In Latvia, the most trusted is radio (60\%), followed by TV (59\%), and the printed press (41\%). The Internet and the social media networks were trusted by $35 \%$ and $21 \%$ of Latvia's inhabitants respectively. These trends are not unique to Latvia: in general, in $26 \mathrm{EU}$ Member States the majority of respondents place greater trust in radio. Likewise, trust in the social media has decreased not only in Latvia but in general 
in $17 \mathrm{EU}$ Member States, in particular in Greece and Latvia, where the decrease amounts to six per cent, compared to research in 2016 (European Union, 2018). The results gained by the quantitative approach do not clarify whether increasing distrust is linked to the development of media literacy among the population or, quite the opposite - the inability to find trusted sources of information and thus the position "I trust nobody". Nevertheless, the results show that the quality of media content and some high-profile cases have decreased public trust in the media in general. Data from the Eurobarometer media trustworthiness index show that, in Lithuania, $35 \%$ of the population have low or no trust in the media, whereas $28 \%$ of respondents have a high level of trust in the media. In Estonia, 29\% assess their trust as high, although the same proportion of people assess their trust in the media as low or non-existent (European Union, 2018).

The Latvian Association of Journalists (LAJ) and the Latvian Union of Journalists (LUJ), the Latvian Media Ethics Council, the Latvian Press Publishers Association, the Latvian Association of Broadcasting Organisations and other smaller organisations linked to the media sector operate in Latvia. The objective of these organisations is to promote the development of their sector, defend its rights, participate in drafting regulatory enactments, and ensure cooperation and information-sharing among the media and professionals in the field (Zelče, 2018). These organisations are quite strong in voicing the opinion of their sector, both in drafting policy documents and regulatory enactments and in responding to relevant issues. ${ }^{2}$ The contribution by the LAJ is significant, foregrounding issues that are important for journalists (for example, an open letter by the LAJ on the impact of Covid-19 on the sector) and also in dealing with other issues related to performance by journalists of their professional duties. Thus, the LAJ, the LUJ and the state police have concluded a Memorandum of Cooperation to take effective action to ensure journalists' security. The Memorandum deals with sharing information in cases when a journalist has received threats in connection with their professional activities (Ģiga, 2020a; Giga 2020b). Although the organisations that unite journalists are of greatest importance in dealing with issues linked to freedom of speech - for instance, the right to obtain information - they also lack financing to expand their activities beyond responding to political decisions and amendments to legal acts.

Examination of the situation in the area of investigative and analytical journalism leads to its assessment as being mediocre/ good in Latvia. State budget resources for this genre of journalism are available through competitions in the framework of the Media Support
Foundations. Information provided by the Social Integration Foundation (last year it administered one of the Media Support Foundation programmes) reveals that, in 2019, seven projects were approved in the category of investigative and analytical journalism (Social Integration Foundation, 2019). The centre of investigative journalism Re:Baltica and the television programmes De facto (public broadcaster) and Nekā personiga (commercial media) are based on investigative journalism. This genre is also the main axis in the work of several newspapers, portals and other TV programmes (for example Aizliegtais panēmiens). In the spring of 2020, the first stories of the investigative programme Atverrtie faili were aired by Latvian Radio. Investigative journalism materials are available to the public; however, the perspective of sustainability rules out regarding the situation as excellent. In view of the fact that investigative journalism is expensive and time-consuming (most often stories cannot be prepared during the day and aired the same evening), concerns arise regarding the costs of content production and the media's ability to afford them. Although investigative journalism does not always ensure a broad audience, to quote Olena Prytula, the former editor-in-chief of the Ukrainian newspaper Ukrayinska Pravda, it is a matter of the media outlet's honour. At the World Press Freedom Day conference organised by UNESCO in 2007, she noted that articles about corruption and violations of the law committed by officials could be printed but the officials were not dismissed. So, "why do we spend our time, money, paper and resources for the next story? The answer is - good investigative journalism is the best way for a newspaper to stand out. It is a matter of quality and pride". (Prytula, 2007) However, allowing for the financial possibilities of the media, making such materials affordable to them is also important. Time and again, the EU announces competitions for support of investigative journalism (European Commission, 2019c); however, the terms require media cooperation on the international level. The next section will focus on media content, specifically, EU topics in press editions.

\section{The EU in media content and audience interest}

To form a notion of how the EU is represented in media content, content analysis was conducted of one media type - the press - and information was collected about programmes dedicated to EU topics in the electronic media. The research was partially influenced by restricted access to periodicals in libraries due to the pandemic-related emergency situation, so that

\footnotetext{
2 For instance, one of these is the Saeima Human Rights and Public Affairs Committee, which examines media-related matters; the minutes of meetings show that the sectoral associations participate regularly in sittings, e.g., in October and November 2019 when the draft laws "Amendments to the law "On the Press and Other Mass Media" and the Law on Public Media and Management Thereof were examined.
} 
only those newspapers that were available in the open reading rooms were analysed (while this article was being written, the National Library of Latvia was not issuing periodicals). The framework of the research was the newspapers Diena and Latvijas Avize in August and from 16-31 October 2019. In total, 125 publications were identified in this period (82 in Latvijas Avize and 43 in Diena), which refer to the EU, the EC or the EP. ${ }^{3}$ The differences in the number of articles can be partially explained by several thematic inserts in Latvijas Avize, for example, "Here, in Europe" or "Green Latvia", comprising several publications that refer to events in - or processes influenced by - the EU. However, the editorial choices of the media themselves can also be identified in terms of the extent to which they make various EU aspects relevant in their content. The priority of front page articles is almost the same in both newspapers - four in Diena and three in Latvijas Avize: front page articles or teasers of articles, referring to the EU, the EC or the EP. Predominantly, these are related to the negotiation stages in Brexit; however, the publications also examine issues relevant for Latvia, closely linked to EU financing, such as road construction, production of agricultural produce, and the like.

As regards themes, the largest number of publications focuses on EU financing (25) and the United Kingdom leaving the EU (23). In total, 20 articles were included in the section "Other", where the EU is represented in a neutral context (for example, the percentage of votes gained by a Latvian political party in the EP election) or less often encountered topics are dealt with. In 15 articles the EU is mentioned in the context of the work of its institutions, with 13 articles comprising statistics comparing the Member States in a certain area or dynamics of indicators over the years in the EU in general. Ten articles examine EU foreign policy, for example regarding relations with the USA, sanctions against Russia, the temporary prohibition of imports of all kinds of seeds and beans from Egypt, the agreement between the EU and Turkey on closing the so-called Balkan migration route, and so on. Six articles refer to potential enlargement of the EU by welcoming new Member States - these were predominantly published at the end of October following the summit of EU leaders, in which North Macedonia and Albania were not invited to join the EU. The visit of the President of Ukraine to Latvia also foregrounded the issue of Ukraine's course towards joining the Union. Five articles comprise references to the impact left by decisions adopted by the EU on the Member States, Latvia among them. Five articles represent the Latvian Members of the European Parliament (EP). Four of these five articles are publications about the areas of work and achievements of the EP
Members, paid for by the European People's Party Group. None of the articles during the period examined touches upon issues of possible enlargement of the Eurozone, common EU values and culture, or the digital single market, which was declared by the Ministry of Foreign Affairs a couple of months later as one of Latvia's priorities in the EU (Ministry of Foreign Affairs, 2020). Hence, it can be concluded that these topics are not on people's agenda either or were not sufficiently foregrounded in the EU itself to gain publicity in the media.

In general, the results of content analysis show that the impact of EU decisions on Latvia has received little analysis in the press. Likewise, the activities of the Latvian deputies in the EU are seldom reported on (in both cases, five publications). This trend has already become entrenched in the media, as pointed out in research by the public policy centre Providus, namely that in many cases information about events in Europe was included in the foreign policy rather than the domestic policy sections of newspapers, thus reinforcing the view that the EU was somewhere far away and associated with Brussels, instead of Latvia being a fully-fledged EU Member State (Akule, 2017). In accordance with the agenda-setting theory, society pays attention to some issues depending on whether they are on the media agenda. However, it is also important that the media set the agenda only if the audience regards stories/ publications as essential or meaningful (Young, 2010). Therefore, a correlation is possible between lack of media representation of the link between decisions adopted in Brussels and daily life in Latvia and people's view that issues dealt with in the EU are far removed from their own life. In Latvia's population survey (2020), conducted to prepare the human development report, approximately half $(53 \%)$ of respondents indicated support for the statement "I am little influenced by the issues that the European Union institutions work on". Older respondents tended to indicate that they are little affected by EU matters. For example, $43 \%$ of young persons in the age group from 18 to 24 years and 58\% of respondents over the age of 76 have a sceptical view of the impact of the EU on their daily life (HDR Survey, 2020). Most probably, this view depends not only on each person's education and occupation but also on information consumed. In the press editions analysed, issues regarding the impact of EU decisions on Latvia constitute only $4 \%$ of the total amount of all publications (which refer to the EU, EC or EP). However, the interest of inhabitants themselves in finding out more about the EU through the media cannot be characterised as high, but rather as average. The statement "I gladly view stories and/ or read articles in the media about various European Union matters" was supported by almost 58\%

\footnotetext{
3 Verbal text (including the format of news in brief) printed in newspapers was analysed, except for sports news, excerpts from fiction, ads, classified ads and TV schedules. Content analysis was conducted according to the topics, the 1-2 most appropriate topics being marked for each article referring to the EU or its institutions - the EC and EP. Afterwards, quantitative content analysis was used to examine the most significant linguistic means used to represent the EU.
} 
Figure 2.3.2. Representation of the EU in thematic cross-section in the newspapers Diena and Latvijas Avīze August and 16-31 October 2019), $n=125$

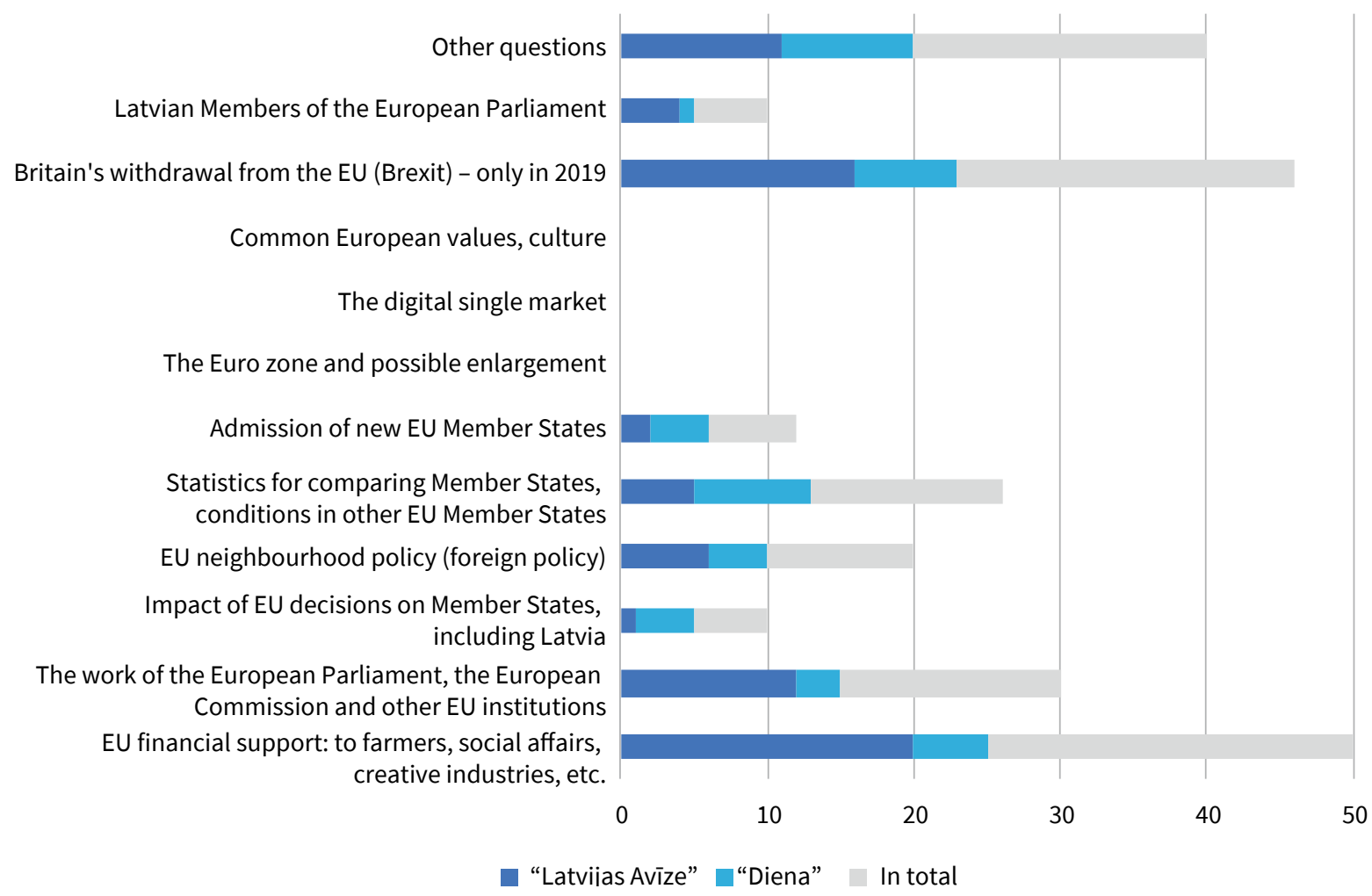

Source: 125 publications in the newspapers Diena and Latvijas Avīze (August and 16-31 October 2019).

of respondents, whereas almost one-third $(31.5 \%)$ of respondents responded negatively to this statement. Moreover, a fairly large share of respondents are indifferent, that is, those who are neither interested nor uninterested in this matter (in some age groups even above 14\%). Respondents with higher education (64\%) consume more media content about the EU. Residential location does not cause major differences - the statement is supported by $59 \%$ of people in Riga (city centre \& suburbs), $60 \%$ in Vidzeme, $52 \%$ in Kurzeme, $55 \%$ in Zemgale, $61 \%$ in Latgale and $56 \%$ in Riga (satellite districts) (HDR Survey, 2020).

Some $72 \%$ of respondents (significantly more than the number of those who indicated that they gladly read articles and watch stories about the EU) believe that the media should provide more explanations about the impact of the EU on our daily life. Although it might seem that, with upcoming elections for the European Parliament - which is also seen as a media event Latvia's people would turn more to media content: in fact only less than one-third of respondents indicate that before the elections for the European Parliament they look more often for information to assess the candidates (HDR Survey, 2020).

At the beginning of the 1970s, Maxwell McCombs and David Weaver introduced the notion of "the need for orientation". The more appropriate/ significant a topic seems to a person and the greater its vagueness/ uncertainty, the greater the wish will be to find orientation or to understand the situation in this unstable, changing world. If a topic does not seem personally relevant, then the need to monitor the situation is lower in terms of consuming media content more actively, hoping to find out about any changes. High relevance together with low uncertainty creates an average need for orientation, whereas high relevance together with high uncertainty causes great curiosity and the wish for constant new information (McComb, Shaw, Weaver, 2014). This need also differs individually in the survey results. Approximately one-third of people are not interested in EU matters, possibly because these seem so distant, which therefore creates no uncertainty or a wish to find out something more. This sense of distance is intensified by press content. Simplifying the outcomes of qualitative content analysis, two ways in which the EU is presented can be discerned. In the first, the EU is represented as "a sponsor", from whom maximum benefit can be obtained. Analysis of the linguistic means used in representation of the $\mathrm{EU}$ reveals frequent use of the expressions "EU support", "attracting EU financing", "receipt of EU financing", "granted from structural funds", "best practice in using funds", and 
the like. Moreover, words that point to obtaining benefit are used: to attract, to invest, to use, to allocate, to receive. Secondly, representation of the EU as a judge who imposes restrictions is marked. This follows from such statements as: "This is the first fine imposed on Sweden under the European General Data Protection Regulation" (Tihonovs, 2019), "to distribute tea, a decision by the European Commission on additions to the EU Novel Food Catalogue is needed" (Diezina, 2019), "the EP committee will verify in Latvia [..] infringements" (Plauka, 2019), "of the 140 million which the European Commission allowed us to borrow temporarily from ourselves, we could not spend any on salary increases" (Mel̦niks, 2019). These are only some examples in which those interviewed or journalists themselves point to sacrificing their discretion and dependence on the EU or the decisions of its institutions. Although this dual representation of the role of the EU - financial benefactor and restrictor - would be sufficient grounds for interest in EU topics in the media ( $72 \%$ of respondents believe the media should provide more explanations about the impact of the EU on our daily life), nevertheless only $58 \%$ of respondents indicated that they gladly consume such content. This is a challenge for the media - to present these topics in a way that would attract the audience. The results of the content analysis show that only a small proportion of articles (4\%) examine the impact of EU decisions on life in Latvia. This, as well as more extensive presentations of work done by Latvian deputies (in the European Parliament), might bring greater clarity to society about the work of EU institutions, decisions adopted and, in general, expand representation of the EU.

In summary, regarding Latvia's population survey, the responses show that, currently, the need to decrease uncertainties with the help of media content is moderate. However, the media have the possibility to make decisions made in the EU and its daily work more attractive for the audience, with more explanation about why these are important for certain societal groups and urging the audience to find out more about them. The media try to elevate the significance of an event by offering live reporting from Brussels. However, the development of society's interest goes beyond media content; moreover, it is a question of how the EU institutions communicate with society and what the content of that communication is. The fact that the position of a Brussels correspondent has been established proves how important it is for journalists to be near the place where relevant EU issues are dealt with. Latvian Radio was the first Latvian media outlet with its own correspondent in Brussels. Ina Strazdina, who held this position for almost 13 years, said in an interview that "this was the time when Latvia acceded to the European Union and NATO, and in 2006 the head of the news department understood that Latvian Radio needed a correspondent in Brussels" (Kaukule, 2019). Oskars Kastēns (Latvian Television's first special correspondent in Brussels), Ansis Bogustovs,
Arnis Krauze, and Gundars Rēders have been Brussels correspondents of Latvian Television (LTV).

Ilze Nagla started working in Brussels as the LTV special correspondent in September of 2014. Ivars Belte, chairman of the LTV Board at the time, was proud that LTV was the first and only Latvian TV station with its own correspondent posted in Europe:

It is important for a public media outlet to be at the epicentre of the European Union, where issues important for the Member States are decided. [..] For Latvian Television it is important to gain on-site and as fast as possible all the recent news affecting Latvia and the other Member States of the European Union; therefore the News Department needs a highlevel professional reporting from Brussels on recent developments. This also allows swift and effective summarising of comments and opinions from experts, and politicians from other states, creating as broad and objective a background as possible for a news story. This will be of decisive importance next year when Latvia will be the presiding state at the Council of the European Union. ([s. n.], 2014)

This event did indeed bring changes not only to the political but also the media agenda. Among these, in 2015, the second reporter of the Latvian Radio - Artjoms Konohovs - began working in Brussels. Latvian Radio explained at the time that:

issues of EU security, political and financial considerations of the Member States have gained relevance [..], so it is important for public radio to be represented in Brussels with two posted correspondents. From now on, Artjoms Konohovs will prepare news stories and interviews in the capital of Belgium, also for the Russian language news programme of Latvian Radio 4 - Dome Square, which is of particular importance for reinforcing the content offered by the Latvian public media to the Russian-speaking audience. (Vanaga, 2015)

Reporter Ilze Nagla noted at the time that during the period when Latvia would be the leader of Europe for the first time in history, her task would be "to tell the audience of LTV what of real importance is going on and what it means to us ([s. n.], 2014)". Although EU topics have regularly appeared in media content in Latvia, also thanks to the activities of special correspondents in the EU, time and again the matter of the costs of a Brussels correspondent and insufficient financing of the public media is raised in public space (Skrebele, 2005; LETA, 2016). Journalists from other media had also gone to Brussels to create stories and articles from the epicentre of events, in connection with Brexit and other relevant developments. Statements from journalists suggest that it is not an easy job. For example, in an interview with Latvijas Avizze Ina Strazdiña notes:

For a journalist, Brussels is professionally one of the hardest posts, alongside London, Moscow or Washington. That is because the structure of the European Union is not simple: administration of a community of 28 states has 
a large bureaucracy and many documents. The greatest challenge is to learn to work with documents and try to retell it simply. In creating stories, I try, first of all, to tell all this to myself or an imaginary person, distant from all these processes. Of course, the international environment is inspiring - BBC, CNN are next to you. Many war correspondents work in Brussels, they have witnessed hell in various regions of the world but had decided to change something in their lives. They say that Brussels is dangerous not because you are shot at but because the amount of information could make your head explode. (Kaukule, 2019)

Here, it is worth returning to the agenda-setting theory. Retrospective insight into media history shows more media projects dedicated to EU matters a couple of years before and after Latvia's accession to the EU. For example, the LTV programme - Eurobus - made by Ansis Bogustovs on the appropriation of EU funds; the Latvian Radio programme Keys to European Funds, made by Imants Austrinšs, and others. Journalists turned into messengers of EU matters, although to a large extent this was linked to EU financing for creating this kind of media content. However, most probably, at the time - 15 years ago - EU matters were much less clear. For example, the programme Eurobus covered actual projects implemented with support from EU funds and written by people like the programme audience, for instance: "Ansis Bogustovs [..] had met an elderly lady, who was writing a project on behalf of the people in her rural municipality who had suffered persecution because she wanted to set up meeting premises in the local community house (DIVA, [W. y.])".

Content paid for by the EU is also included in the media today, for example as special inserts in weekly press editions. Taking into account the results of content analysis, it is possible that, in the current situation, these sponsored inserts are almost the only way for EU institutions to inform the audience about diverse and different EU matters through media content.

\section{Conclusions}

The question arises - can it be said at any moment that Europeanization has occurred and all criteria have been met, or is the process still ongoing? As long as the EU exists, the process of reciprocal adaptation will be inevitable. Although Latvia has been an EU Member State for more than 15 years and EU legal acts have been formally taken over, a more detailed analysis shows that part of the criteria, for example in the area of freedom of speech, is an ideal "moral obligation", which not only the candidate countries but also the Member States should strive to attain. Moreover, examination of events in the Latvian media environment outlines processes and indicators that could be labelled de-Europeanization of the media environment. For instance, financing of the public media is not among the official criteria for accession to the EU. However, in Latvia, it is one of the smallest among the Member States (Saurwein, Eberwein, Karmasin, 2019). Likewise, the number of news departments has decreased during recent years, which is a shock for diversity of opinion - for example, the LNT news department and the news programme Latvian Time by PBK, which was produced in Latvia. At the beginning of the summer of 2020, the idea appeared in the media that news and analytical programmes in Russian, available on LTV7, could be transferred to a multimedia platform (Petrova, 2020). However, this step would mean that part of the audience - which lacks the skills, resources or other factors for accessing the news in Russian produced in Latvia in the internet environment - would have to switch over to one of the TV programmes close to the Kremlin, which enjoy a high level of trust among non-Latvians (NEPLP, Latvijas Fakti, 2018). A study of the media audience of 2018 found:

Analysis of answers given by non-Latvians shows that this audience expresses greatest trust in Russian news sources $(41 \%)$, followed by local news sources in the hierarchy of trust (34\%) and Western news sources $(19 \%)$, causing valid concern for non-Latvians' level of trust in local information space and the extent to which the local mass media can compete with the Russian media. (NEPLP, Latvijas Fakti, 2018)

Examination of audience interest in representation of EU topics in the media and, as an example, EU topics represented in the press, reveals parallel processes: on the one hand Europeanization with a strong need to continue safeguarding freedom of speech and the media. Decreasing this is the first step towards de-Europeanization, which can be observed in some other European states, such as Hungary (Rozenberga, 2015); and on the other hand, de-Europeanization. This is aptly expressed by the Latvian proverb included in the title of this Chapter "Not every tree in the forest stands tall". When compliance with EU norms is achieved in one area, unexpected circumstances may deteriorate the situation in another. Many aims set for media freedom may be achieved and maintained by instruments of national media policy; however, some of those aims are in the hands of the sector itself, and excessive state interference in their regulation - such as improving the internal management of the media - would be incompatible with the principle of freedom and independence of the media.

Whether Latvia wants more intensive Europeanization of the media environment is a policy issue. Perhaps representation of EU matters in the media (for example, presenting the EU as sponsor and judge, which fosters the idea that the EU is located far away, rather than Latvia being a part of it) is a factor influencing (non) activity by voters in elections for the EP. To promote greater interest in EU topics among the population, media policy instruments can be used and representation of EU matters can be included in the categories of the Media Support Foundation, in which the media may 
compete for support from the state budget. This could be an incentive for more analysis of the way EU decisions influence Latvia, as well as possibly reaching a younger audience through innovative projects. Perhaps younger people are not interested in EU topics because they do not find topics of interest in media content on the EU. EU topics are one more area where useful training for journalists should be organised. Although time and again media representatives visit the EP (European Parliamentary Bureau in Latvia, 2020), this format is useful only for developing some elements of content and for creating first impressions. An in-depth understanding is needed to analyse the processes in the EU and to identify problems. This, in turn, would give the opportunity for the social sciences programmes of Latvian higher education institutions to create synergies and offer, for instance, a continuous professional training programme on creating media content on EU matters, comprising knowledge on diplomacy, EU law, economics and other sectors. Although some articles were published in the analysed press editions that, for example, compared the Member States with respect to some indicators and dedicated at least one page to events abroad, in general, however, as regards representation of the EU, the media environment is characterised by vertical rather than horizontal Europeanization. News content has a greater communicative link between processes on the national and the European (Brussels, the EU institutions) level. Horizontal Europeanization, in turn, is defined as an intensified communicative link between some EU Member States. If horizontal Europeanization is weak, the media are more interested in events within the national-level political environment of other Member States, whereas strong horizontal Europeanization means that the media create a communicative link between the political spheres of two or several states (Falkheimer, Blach-Ørsten, Kæmsgaard Eberholst et al., 2017).

Currently, the conclusions are based on analysis of the press published in Latvian. In expanding the research area, it would be important to identify representation of the EU in the Latvian media in other languages both the frequency and themes of representation and the linguistic means used. Undeniably, Europeanization of society to a large extent depends on the quality and culture of journalism. However, content created is influential only if society regards it as essential and significant. Although the media can create interest in following these issues, the way in which the European Parliament, the European Commission, the Latvian members of the European Parliament, and so on communicate is also important. At the beginning of 2020, the Ministry of Foreign Affairs of the Republic of Latvia announced priority EU issues for Latvia in 2020. Potentially, support for freedom of speech could be discerned in the section "Protecting people and freedoms". The media could be indirectly linked to the priority "The Single Market and its Digitalisation" and the section "The EU - a Stronger Global Player", which underscores, for example, the fight against such hybrid threats as disinformation and cyber-attacks (Ministry of Foreign Affairs, 2020). The amount of information about these issues found in public space and the media could be a good research question for another study.

\section{Main findings and most important tasks}

\section{Main findings}

Three events and processes can be regarded as major achievements in the path towards Europeanization of Latvia's media. Firstly, harmonising legal regulation on the Latvian media environment with EU requirements amendments to the Radio and Television Law aligned matters involving advertising and other issues. Secondly, Latvia's path towards ensuring increasingly benevolent conditions for freedom of speech is noteworthy, as shown by Latvia's rise from being ranked at 39 in 2013 to 22 in 2020 in the press freedom index maintained by the organisation Reporters Without Borders. The third event is approval of "Mass Media Policy Guidelines of Latvia, 2016-2020" and the implementation plan for these in 2016, which opened possibilities for the commercial media to apply for financing from the Media Support Foundation to produce socially significant and qualitative content; included the first activities for strengthening media literacy among people in Latvia, envisaged financial support for media self-organisation - for example, the sector established the Latvian Media Ethics Council to improve the quality of journalism.

\section{Most important tasks}

Changes in the media environment have resulted in threats not only to the existence of the national and regional printed press in Latvia. The flow of advertising revenue to global platforms such as Google and Facebook decreases revenue for the Latvian media, which, in turn, jeopardises their possibilities to produce qualitative original content, to compete with the offer of foreign media and, in general, their sustainability. Thus, lack of financing is the most important challenge in the media environment, as is reflected both in financing for the public media - among the lowest in the European Union - and in the closure of some media outlets. This, in turn, decreases 
diversity of opinions and reveals tendencies of de-Europeanization. Latvia's population surveys show that only $58 \%$ of respondents gladly view stories and read articles on EU matters. Analysis of daily newspapers, which shows representation of the EU in two pronounced categories - sponsor and judge - also confirms distancing from the EU. Few publications analyse the impact of EU decisions on life in Latvia, which perhaps explains the moderate interest among people in Latvia about EU topics in general because the EU is perceived as existing outside Latvia, even though Latvia is part of the EU.

It is important to be alert to ensure freedom of speech and the media, to prevent derogations from the criteria of media freedom as defined by the EC and which are essential characteristics that allow the media environment to be considered as independent, qualitative and influential. It is also worth keeping in mind the fine line beyond which restrictions on freedom of speech begin in planning the fight against disinformation. It is important to ensure benevolent working conditions for the public media as well as to draft media policy planning documents for the next planning period (from 2021), to ensure possibilities of state support for the commercial media to maintain diversity and thus also diversity of opinion. The media have possibilities to look for more diverse ways to represent the EU and maintain high interest among the audience, reporting more on the way EU decisions impact Latvia. This is also a challenge for communication by the EU, the EC and the EP with society regarding processes and decisions, which, although occurring physically at a distance, are essential for all Member States. 


\subsection{European values and the Europeanization of Latvian society}

\section{Vita Zelče}

Belonging to Europe was one of the sources of motivation for Latvia's regaining statehood in the second half of the 1980s. At that time, public intellectuals emphasised Latvia's need to return to Europe, noting that not only this country but Europe as a whole would benefit from it. For example, during the Poetry Days in September of 1989, poet Leons Briedis, in front of the monument to fellow-poet Rainis, said "We should never forget that Latvia has always belonged to Europe, that Latvian culture has always been a part of European culture; we should regain, cultivate and develop our European mentality; Latvia should return to Europe, once and for all" (Briedis, 1989, 2). During the attempted Soviet coup of August 1991, which was so decisive for independence, artist and politician Džemma Skulme underscored that the Latvian people's ability to resist Soviet power stemmed from "memories about Europe" and "a European view of life" maintained internally, despite the occupation (Skulme, 1991, 1). During the years of the Awakening, the wish to belong to Europe was proven not only by the great importance of visiting Western parliamentarians and representatives of Western culture on the Latvian public agenda but also by changing the time zone, switching from Moscow time to so-called Eastern European Time (UTC+2), and launching the first direct international flights from Riga Airport (Bleiere, 1996, 14-19). Warnings were heard in public space that returning to Europe would not be easy because half a century of life on the other side of the Iron Curtain had substantially changed Latvia, alienating it from the Western order of life and introducing a Soviet mentality and daily dealings (Box 2.4.1.). Likewise, the Europe of the last decades of the $20^{\text {th }}$ century, on which Latvia set its hopes for the future, was another Europe, not at all like the one from which Latvia was cut off in 1940. The Europe of the 1930s was a mixture of not only democracy, human rights, and the values of Western culture and way of life but also of international

\section{Box 2.4.1.}

\section{Marginalia or comments on Czestaw Miłosz's poem “A Child of Europe" (1946) by translator Uldis Bērzinš in 1991}

"[..] Some of us have started thinking that we are - for Europe - an exception of a kind, in need of correctional education ... This attitude has become fashionable abroad - homo sovieticus: lazy, inaccurate, never on time, and so on, and some here, in this latitude, repeat and decline it as at school - homo sovieticus, homines sovietici, hominum sovieticorum, hominibus sovieticis, I deserve this, and this is not enough... Shall we not arrive at nihilism, self-poisoning and longings for new totalitarianism if we allow inferiority complexes and an orphans' psychology to flourish within us? Isn't this at times a masochistic pleasure in self-humiliation? Will it not look for balance in sadistic aggression or, perhaps, in neo-communism or neo-Nazism? Better repeat three times: I am not an orphan, I am a child of Europe, I am a child of Europe! [..]

Those who denigrate themselves and sigh: we are those homines sovietici - this is again the psychology of captivity, orientation towards foreign power: are we betraying ourselves again? 15 May came, down with democracy, Ulmanis is stronger. 1940 came - down with Ulmanis, Russia is stronger. Then, in 1945, again we betray ourselves and each other. And then that huge enthusiasm for the West because the kopek is there! Where the kopek is, there the truth lies.

But we are children of Europe. We were and remain hostages of Europe, in this skittishly irrational captivity... The Germans understand it, but the let the Belgians or the Danes pass so brilliantly all the tests of this century, live fifty years or so in the barracks of people doomed to non-existence, in the camera of ethnic lifers. But our Europe was there, within us; we endured."

Source: Bērziņš, Uldis (1991). [Translator's comments for Czesław Miłosz’s poem “The Child of Europe.”] Literatūra un Māksla, July 19,9 . 


\section{European Union values}

The EU's values are common to all Member States, and its society is characterised by integration, tolerance, justice, solidarity and non-discrimination. These values are part of the European lifestyle.

- human dignity

- freedom

- democracy

- equality

- rule of law

- human rights

Source: European Union. Goals and values of the EU, in: Official website of the European Union. Retrieved from https://europa.eu/ european-union/about-eu/eu-in-brief_en

contradictions and conflicts, totalitarianism, authoritarianism, prerogatives with respect to seizing territories, and fascist values. In restoring its independent statehood, Latvia also strove to create a democratic republic rather than return to the Latvia of 15 May 1934 established by Kārlis Ulmanis.

In the period after the Second World War emerged a post-national, prosperous, pacific and collaboration-oriented Europe (Judt 2005, 6), including, of course, the older cultural heritage of the continent. The foundations of modern European civilisation date back to the 17th century, based on a synthesis of ancient Greek philosophy, Roman civil law, and Christian theology. Nowadays, to social values and the principles of solidarity, which have evolved during the long history of the struggle for human rights, are added establishing justice and democracy. Likewise, embodying individual autonomy in politics and daily life is important for contemporary Europe. Individual freedom occupies an important place in the individual and collective identity of Europeans. It is characterised by a post-hegemonic world order that has replaced colonialism and imperialism, previously implemented by the countries of this continent (Delanty 2019, l-liii).

A clear and deliberate aim - accession to the European Union (EU) - was an element in the process of restoring Latvia's independent statehood. Applying for membership in the EU in 1995 marked the beginning of an intensive process of Europeanization, taking the form of learning and a great deal of political, social and cultural activity to take over European norms and values from all areas of life (Ozolina 2013, 401-403). The term "Europeanization" denotes the diffusion of European norms and practices in public administration and societies in the EU Member States. After Latvia's accession to this economic and political union of European states, integration into its system of values continued (Box 2.4.2.), simultaneously offering Latvia's contribution to the creation and enrichment of "the common home" (Box 2.4.3.).

This section examines and assesses the relationship of Latvia's society with EU values, focusing on the role that history plays in shaping values, as well as the attitude of Latvian society towards fundamental European values and post-material values, whose significance is growing. The data examined and examples allow us to assess the outcomes of Latvia's Europeanization.

\section{The significance of past lessons in European values}

The collapse of the Soviet Union and the communist system changed Europe. Europe, divided by the Iron Curtain, ceased to exist, replaced by the so-called post-war Europe of 1945-1989, where opposition had developed between the standards and lifestyles in the Western and the Eastern parts of the continent. The formation of a common Europe also meant returning to a common past. At the end of the 20th century, "Europe' had to be rethought," and answers had to be found to many questions regarding the identity of Europeans (Judt 2005, 749-752). Post-war Western Europe was built on the basis of intentionally disremembering the recent past, and Eastern Europe on the basis of Soviet concepts of history, with memories of the national past stifled by repressive measures. At the end of the 1980s, the countries of Western Europe had already started to surrender many topics of pride in their national history and mythology and were examining the actions of their people during the Second World War, such as involvement in the Holocaust and collaboration with the Nazis. Narratives of national history, in turn, flourished in post-communist countries, emphasising losses incurred during the communist period, crimes and humiliations suffered. Actually, the year 1989 launched the age of historical post-amnesia, which 


\section{Speech by President Vaira Vīkse-Freiberga at the official ceremony of the accession of Latvia to the European Union in Riga's Dome Square on 1 May 2004}

"[..] The EU has not been invaded, has not been put together by force. The EU has grown, agreed on common values, common aims and common ideals. The EU was born after the bloody conflict of the Second World War, when nations understood that the time had come to forget hatred, to forget ambitions and the wish to impose one's will upon others and that much more could be achieved by living in peace and accord with one's neighbour, by working together to reach common welfare, growth and prosperity. This has been achieved - countries are lining up at the door of the EU, people are lining up at the borders of the EU, wanting to come in; we have succeeded in passing all tests, we have achieved what many, including we Latvians, had not believed Latvia would be able to achieve. [..]

We have become citizens of Europe and it is up to us not only to make our Latvia beautiful, fair, serene and an object of admiration, it is also up to us to make Europe our common home, a home we can all be happy in and proud of. [..]

We shall create values that are dear to us, we shall build this house of Europe together, it will be a good home for us, it will be the home of our friends and neighbours, side by side we shall be able to build it together and proudly sing this anthem of the EU, this ode to joy and this testimony of brotherhood, not an empty, imposed, propagandistic brotherhood but one that comes from a deep conviction that each person has worth, that each person has entered this world with a mission, with work to be done that is dignified and worthy of consideration. We are all of equal value before God and the world. We are all brethren because we are human beings, and we, Latvians, join this family with our own features, our diversity, our creative spirit, our culture, our heart and soul. [..]"

Source: Vīke-Freiberga, V. (2007). 1999-2007 [V.V.-F. 4plus4. $\infty$. Speeches. 1999-2007]. Rīga: Pētergailis, 363-364.

included new risks for the system of values and security and created the possibility of conflict between social and ethnic groups. This was harshly proven by the events of the 1990s in the former Yugoslavia, where old wounds of the past were used as a pretext for wars between newly established states, ethnic cleansing, and mass murder. The numerous tragedies in the Balkans foregrounded issues of human rights on the international agenda (Judt 2002; Judt 2005, 665-683).

Recognition of human rights as the regulatory basis for political action along with moral assessment in the EU determined the centrality of the theme of the Holocaust in European identity and collective memory (Asmane, 2008, 47). In 1995, the European Parliament (EP) adopted a resolution on Holocaust Remembrance Day. This was substantiated by flourishing racism, anti-Semitism and xenophobia at the time and by the need to respond to that threat (EU, 1995). The tools to be used for preventing violence were remembrance and education. In practice, this meant that sharing Holocaust remembrance and lessons began in policy at both international and national level through various events, activities by non-governmental organisations, the media, cinema, museums, tourism, literature and other activities to ease xenophobia, racism and nationalistic prejudices (Gensburger \& Lefranc 2020, 14-16). In 2005, the EP adopted a notable resolution on commemoration of the victims of the Holocaust, anti-Semitism and racism. It appointed 27 January, the day when Auschwitz was liberated in 1945, as "Holocaust Memorial Day" in the EU (European Parliament, 2005a). The European Council's Framework Decision on Use of Criminal Law in the Fight against Certain Forms and Expressions of Racism and Xenophobia, adopted in 2008, imposed the obligation on all Member States to apply sanctions for intentional justification, denial or gross banalization of crimes of genocide, crimes against humanity, or war crimes. This decision is binding upon all Member States, including Latvia (Council of the EU, 2008).

Historian Tony Judt, writing about the beginning of integrating the post-communist countries in Europe, underscored that recognition of the Holocaust had been their "entry ticket" to Europe (Judt 2005, 803). In preparing for accession negotiations with the EU, Latvia's homework, along with the other candidate countries, included developing and integrating in the system of education knowledge about the Holocaust, including Holocaust remembrance rituals in the national political agenda, assuming responsibility for the consequences of criminal collaboration with the Nazi regime by the people living in its territory, as well as complying with the human rights approach to viewing national history. At the end of 1998, at the instance of President Guntis Ulmanis, the Committee of Latvian Historians was established, its main task being to identify and explore the topic "Crimes against Humanity during Two Occupations: 1940-1956". Its working priority was to develop knowledge about the Holocaust. Studies, based on meticulously verified 
facts, on the extermination of Jews in all regions of Latvia were conducted in the coming years (Zelče, 2009, 47-50). Historian Aivars Stranga, forecasting that an understanding of the Holocaust as a crime against humanity would take root in Latvian society, underscored: "... a broad understanding of the history of the Holocaust and the ability to feel the Holocaust as a huge tragedy for all Latvia will develop gradually, as the result of serious and lasting educational work. The broadening and deepening of this understanding are closely linked to the political and economic development of the Latvian state. It is hard to imagine that this could be possible without overcoming the rather widespread poverty [..], unemployment, poor material conditions of schools, teachers and students; it is hard to hope that the history of the Holocaust will assume a place of some importance in the consciousness of people burdened by their daily hardships." (Stranga, 2000)

While doing its homework for accession to the $\mathrm{EU}$, and even when a member, Latvia as a state has been attempting to change its people's attitude to the Holocaust. For several decades now this theme has been a priority in the scientific research of Latvian history and of public history. The University of Latvia's Centre for Judaic Studies (established in 1998), the museum and documentation centre "Jews in Latvia" (1989), the Memorial to Žanis Lipke in Ķipsala, Rīga, (2012) are operating successfully, and a "Museum of the Riga Ghetto and the Latvian Holocaust" (2010) has opened. Exhibitions in other museums are dedicated to the history of the Holocaust, and virtual exhibitions are offered to the public. For instance, the internet site of the Latvian Museum of Occupation offers the exhibition "Rumbula 1941" (2017). Much has been done in the area of education, both methodological and multimedia study aids have been produced, and schoolchildren prepare their research projects on Holocaust topics, which are also the focus of local historical research work in schools. In Latvia, 650 saviours of Jews have been identified; several of these have received awards from the State of Latvia. Memorials on sites for the remembrance of Holocaust victims have been set up in the capital city and elsewhere in Latvia (Melers, 2013), the website of the University of Latvia's Centre for Judaic Studies includes "Holocaust Memorial Places in Latvia" (memorialplaces.lu.lv). Texts of global importance dedicated to the Holocaust and memoirs by Holocaust survivors of atrocities perpetrated in Latvia have been published (or re-published) in Latvian. The highest officials of state participate in Holocaust remembrance events on 4 July and 30 November. Since 30 November 2016, the Rumbula victims are also commemorated by placing candles at the Freedom Monument in Riga. New Holocaust remembrance rituals have been established. In recent years, cultural output addressed to a general audience deals with Holocaust topics: examples include Māris Bērzinšs' novel "The Taste of Lead" (2015, staged at the National Theatre in 2016); the documentaries "Ghetto
Stories" (2013, director Linda Olte) and "Eleven" (2016, director Gunta Gaidamoviča); the movie "Father Night" (2018, director Dāvis Sīmanis) and "The City on the River" (2020, director Viesturs Kairišs); the episode "Holocaust. Collective Amnesia" included in the TV historical programme cycle "The Keys" (2018, author Mārtiņš Ķibilds, directors Ugis Olte, Dainis Kḷava, Reinis Spale).

The tragic history of Latvian Jews is gradually playing an ever-growing role in Latvia's collective history. Thus it could be asserted that an important step has also been taken towards Europeanization in understanding the past and human rights. However, one cannot say that anti-Semitism no longer exists and that everyone in Latvia, looking at the history of the Holocaust, would be aware of the meaning of human rights. In 2015, the data of the global anti-Semitism index show that $28 \%$ of Latvia's inhabitants can to some extent be regarded as being anti-Semitic. This indicator is below the average indicator in Eastern Europe (34\%) and slightly above the indicator in Western Europe (24\%) (ADL, 2015). It can be assumed that Latvian anti-Semitism has a downwardly moving trend. The outcomes of a Latvian population survey conducted in 2020 reveal that $67.3 \%$ of respondents hold the view that, in Europe, the Holocaust is seen as the ultimate crime against humanity (Figure 2.4.1.), with $27.3 \%$ responding with a convincing "yes".

However, almost one-fifth of respondents (18.3\%) have no opinion or are unable to answer the question, which shows that almost one-fifth of people in Latvia lack knowledge and understanding of the Holocaust as a crime against humanity, thus also pointing to potential ground for the flourishing of racism, xenophobia, and ethnic hatred. No significant differences between various age groups can be discerned in the responses, so it cannot be asserted that generation change in the post-communist period has had a particular impact on the understanding of the Holocaust. Indicators of education are much more important. Pronounced differences in attitude towards the Holocaust can be observed among people with high and low levels of education (Figure 2.4.2.). This allows appreciating the great importance of national history and remembrance policy and of educational and cultural institutions, since education serves as the most important tool in Europeanization of notions of and lessons from history.

Other indicators characterising Latvia's inhabitants mark differences in attitudes towards the place of the Holocaust in European identity to a lesser extent. For example, from the perspective of everyday language used in the family, among Latvian-speaking families answering the question "In your opinion, is the Holocaust seen in Europe as the ultimate crime against humanity?", $66.2 \%$ answered "yes" and $13.9 \%$ "no", while $19.9 \%$ were unable to answer the question. In Russian-speaking families, the breakdown was as follows: $69.3 \%, 15.2 \%$ and $15.5 \%$. The responses given by Latvian citizens were $67.8 \%, 14.9 \%$ and $17.3 \%$, whereas the answers 
Figure 2.4.1. Comparison of responses by Latvian inhabitants of different age groups to the question: "In your opinion, is the Holocaust seen in Europe as the ultimate crime against humanity?" (\%)

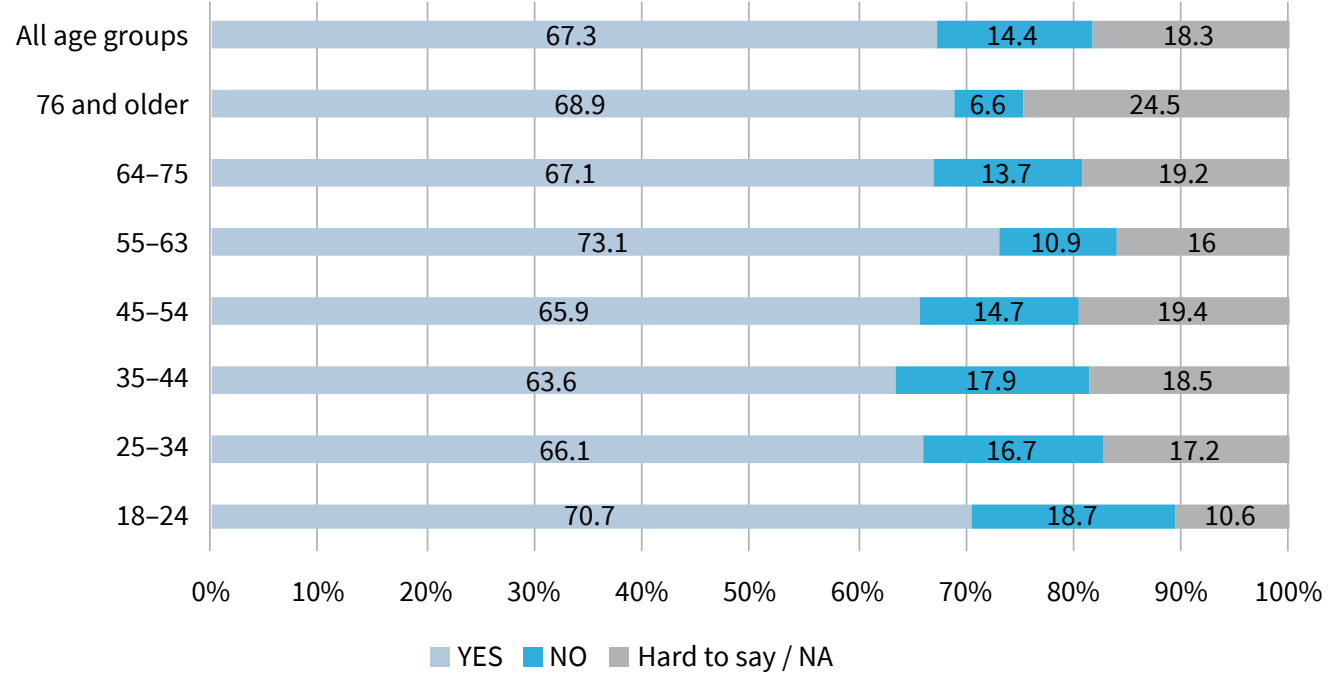

Source: HDR Survey 2020.

Figure 2.4.2. Comparison of responses by Latvian inhabitants with different levels of education to the question "In your opinion, is the Holocaust seen in Europe as the ultimate crime against humanity?" (\%)

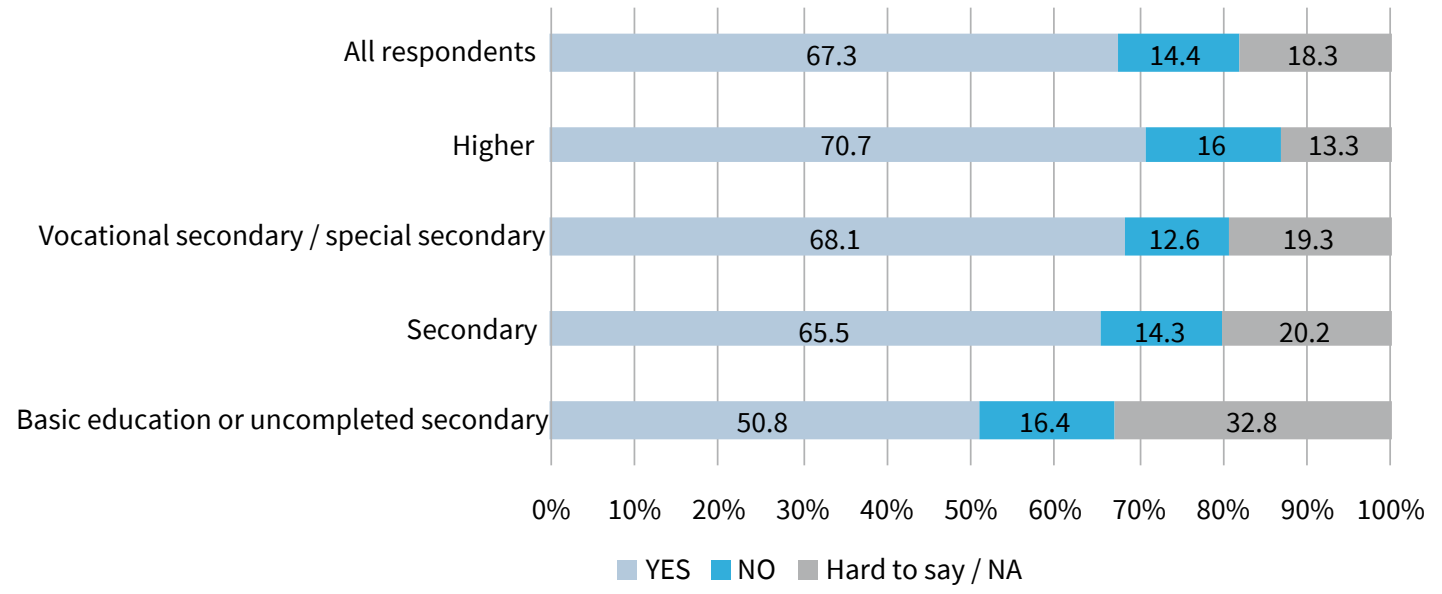

Source: HDR Survey 2020.

from non-citizens and citizens of other states were $64.7 \%, 11.8 \%$ and $23.5 \%$. Of those surveyed, $69 \%$ of men and $65.9 \%$ of women recognised that in Europe the Holocaust was seen as the ultimate crime against humanity. Negative answers were given by $16.9 \%$ of men and $12.2 \%$ of women, while no answers were provided by $14.1 \%$ of the men surveyed and $21.9 \%$ of the women (HDR Survey 2020). At the end of 2018, in the framework of a Eurobarometer study, a survey was conducted in EU countries to identify perceptions of the level of anti-Semitism. Latvia is among the countries where respondents were inclined to answer that anti-Semitism was not an issue in their country. Only $1 \%$ noted that it was a very significant problem and $13 \%$ a somewhat significant problem. The EU average responses to this question are $15 \%$ and $35 \%$. By contrast, in confirming or denying the statement "People deny the genocide of Jews, the Holocaust", $18 \%$ of Latvian inhabitants surveyed upheld this description of the situation but $68 \%$ noted that it was not the case, with $13 \%$ neither confirming nor denying this statement. In EU countries, on average, this statement was upheld by $53 \%$ of respondents, with $38 \%$ denying it, while $9 \%$ could not provide an answer (EC 2019b, 8, 17). These data allow the conclusion that 
the lesson of the Holocaust as a crime has been rather well learnt in Latvia and is integrated into the value set. At the same time, other processes (which have not been systematically studied), such as comments on the Internet, everyday speech, the small number of participants at remembrance rituals, are grounds for caution and the need to be aware that currently the history of the Holocaust as criminal disregard for human rights may be functioning only superficially in the collective memory and the system of values - on the level of politically correct behaviour and basic facts and statements taught at school. Hence, in the embodiment of the Holocaust, work on memory policy and culture should be given priority.

Attitudes of other European countries (in particular, West European) towards crimes against humanity perpetrated by the communist regime and the assessment and view of them, seen from the human rights perspective, remain important for people in Latvia (similarly to other post-communist countries). These started evolving in the EU with accession of the post-communist states to the Union. The EP passed several resolutions urging recognition of crimes committed by communism and commemoration of their victims. The resolution of 2005 on the $60^{\text {th }}$ anniversary of the end of the Second World War (8 May 1945) underscored that "all victims of Nazi tyranny" were commemorated and mourned, noting that "for some nations the end of World War II meant renewed tyranny inflicted by the Stalinist Soviet Union," and brought to those nations "the magnitude of the suffering, injustice and long-term social, political and economic degradation" (European Parliament, 2005b). The EP Declaration of 2008 on declaring 23 August the European Day of Remembrance for Victims of Stalinism and Nazism (European Parliament, 2008) and the resolution adopted in 2009 on European conscience and totalitarianism (European Parliament, 2009) were important in co-examining and equating $\mathrm{Nazi}$ and communist crimes against humanity. The European concept of "two totalitarianisms" has also been embodied in the House of European History, which was opened in May 2017 and which makes the Holocaust and the communist terror an integral part of the continent's history (Box 2.4.4.) (more extensively on EU policy with respect to remembrance of communist crimes, see Neumayer, 2019).

Several items of Latvian cultural output touching on communist crimes have gained international recognition and an international audience. For example, the documentary "The Soviet Story" (2008, director Edvīns Šnore), the movie "The Chronicles of Melanie" (2016, director Viesturs Kairišs), and Nora Ikstenas' novel "Soviet Milk" (2015). However, approximately one-fourth of Latvia's inhabitants consider that the crimes against humanity perpetrated by the communist regime (that is, the Soviet Union) are not condemned in present-day Europe. The majority of older people adhere to this opinion. Approximately $17 \%$ of respondents in all age groups are unable to answer the question whether these crimes are condemned in Europe (Figure 2.4.3.). A difference in opinions is observed between groups of Latvia's inhabitants with Latvian or Russian as the language in the family, and those who have or do not have Latvian citizenship (Figure 2.4.4.). Education indicators are also important. They show that $20.9 \%$ of respondents without secondary education are unable to answer the question: "In your opinion, are crimes against humanity perpetrated by the communist regime (i.e., the Soviet Union) condemned in Europe?"

Shared memories and collective remembrance of past events is a pre-requisite for creating in people a sense of belonging to their country and the EU alike. Europeanization of the understanding of history is important for integration of Latvia's people in the system of European values. As such, this makes people neither better nor worse but is able to influence, both directly and indirectly, individuals' attitude not only towards the past but also towards the values of the present age. The objective of commemorating history, saturated

\section{Box 2.4.4.}

\section{Member of the European Parliament Sandra Kalniete on the House of European History}

"On 4 May 2017, the House of European History was opened. For me, it was a moment of great satisfaction when I saw in the exhibition the virtual stands with Hitler and Stalin side by side, the swastika alongside the hammer and sickle. All visitors to the museum will be able to see with their own eyes how similar in their structure and ideology and in their criminal essence both major totalitarian regimes of the 20th century - Nazism and communism - were. I hope that the House of European History will help Europeans to better understand the value of the European Union for the peace and stability of our continent and will serve as some protection against succumbing lightly to florid speeches, which right- and left-wing populists engage in. They have forgotten the sea of blood that Europeans had to wade through in the 20th century until opposition was replaced by a culture of collaboration."

Source: Kalniete, S. (2017). Cinītis [Small mound]. Rīga: Jānis Roze publishers, 306. 
Figure 2.4.3. Comparison of responses provided by Latvian inhabitants belonging to different age groups to the question: "In your opinion, are crimes against humanity perpetrated by the communist regime (i.e., the Soviet Union) condemned in Europe?" (\%)

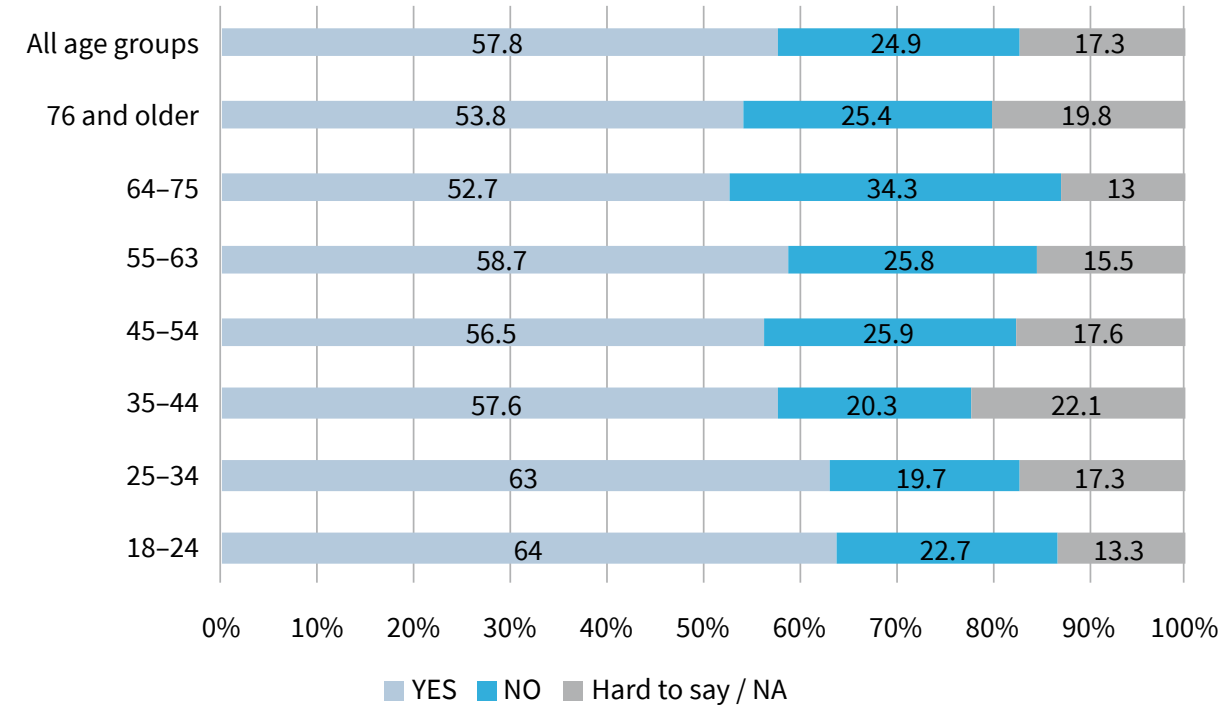

Source: HDR Survey 2020

Figure 2.4.4. Comparison of responses provided by various social groups of Latvia's inhabitants to the question: "In your opinion, are crimes against humanity perpetrated by the communist regime (i.e., the Soviet Union) condemned in Europe?" (\%)

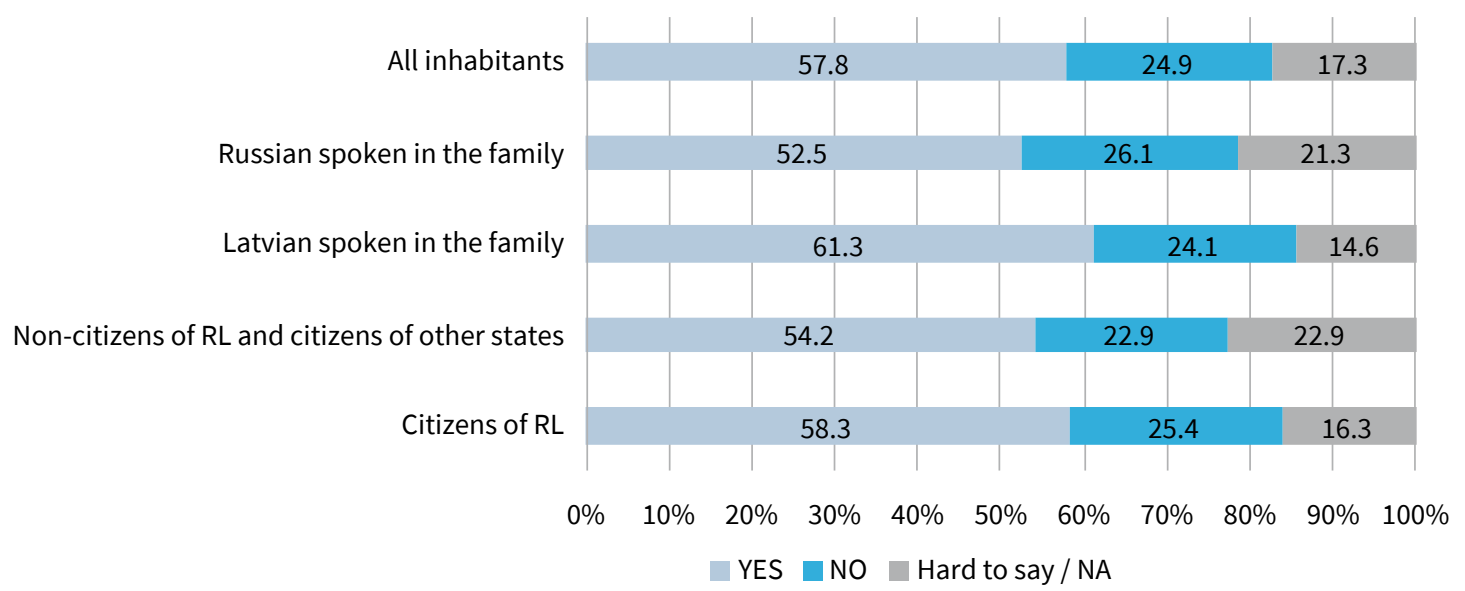

Source: HDR Survey 2020.

with violence (war, genocide, repression), and of human victims is to remind contemporary Europeans of the meaning and values of the democratic order and their implementation in their actual daily life.

\section{Contemporary European values}

Since restoration of its statehood, Latvia has existed in the form of a democratic state, so that the way of life and values that it offers have become self-evident and taken for granted. Usually, values are understood as significant aims that society and individuals are striving for. Studies of the values of extensive regions throughout the world are customary in the practice of sociological research (Latvian research institutions have also participated in these), which allows forming insights into value systems and their priorities in certain parts of the world and comparing them simultaneously (Kūle, 2016, 2018). Undeniably, a major or minor difference exists in the understanding of Europe between the so-called new and old Europe. There is no consensus in the understanding of identity and the hierarchy of values between parts of the continent and states. This has also 
been influenced by the economic crisis of 2008/2009, the unprecedented refugee crisis, the Brexit referendum in 2016, the flourishing of right-wing populism, and the political destabilisation of Italy in 2018 (Delanty, 2019, 307-311). The situation caused by Covid-19 influences and will continue to influence Europeans' values and their implementation in practice.

Many European values, for a part of Latvian society, belong to moral obligations. This is shown by Eurobarometer studies, conducted by the EC, with the objective of monitoring public opinion in EU states. These studies identify people's attitude towards European values in two dimensions. First of all, in the ideal values that best represent the EU, and the actual - values that are most important for individuals. The surveys reveal that people living in the EU and Latvia first among them associate European values with democracy, human rights, and peace. Under the influence of contextual factors (for example, terrorist acts, the wars in Ukraine and Syria, large refugee flows), these main (and other) values have exchanged places over time. The most recent surveys show that the majority of people living in the EU believe that European values are mostly represented by peace. People in Latvia, in turn, most pronouncedly associate EU values with human rights. However, in surveys conducted in Latvia, a large part of the results regarding values that best represent the EU does not differ significantly from the average indicators of EU countries overall (Table 2.4.1.).

When responding about their personal values, the majority of people living in EU countries mention peace, human rights, respect for human life, democracy, and individual freedom. The constant importance of peace determines not only the basic concept of the EU as a union of countries that do not wage war among themselves but also the current security situation, in which both terrorist acts occurring in Europe as well as the growing relevance of new forms of warfare (hybrid war, cyberwar, infowar) are cause for concern. For the people of Latvia (almost constantly), human rights, peace and individual freedom are the most important. This compares with "the average European", for whom the most important personal values are individual freedom, human rights, and respect for other cultures. It

\section{Table 2.4.1. Values representing the EU (\%, maximum of 3 answers)}

\begin{tabular}{|c|c|c|c|c|c|c|c|c|c|c|c|c|}
\hline 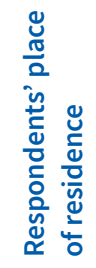 & 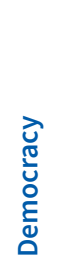 & 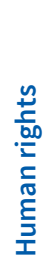 & $\begin{array}{l}\underset{\mathbb{J}}{\mathbb{U}} \\
\mathbb{0}\end{array}$ & J & 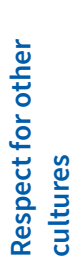 & 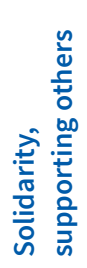 & 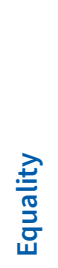 & 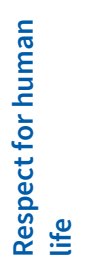 & 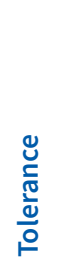 & 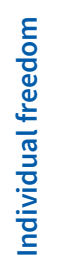 & 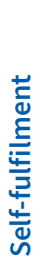 & $\frac{\text { 음 }}{.00}$ \\
\hline \multicolumn{13}{|l|}{2006} \\
\hline EU25 & 38 & 38 & 36 & 24 & 19 & 17 & 14 & 13 & 11 & 10 & 4 & 3 \\
\hline Latvia & 36 & 46 & 37 & 29 & 21 & 21 & 12 & 13 & 6 & 16 & 6 & 2 \\
\hline \multicolumn{13}{|l|}{2013} \\
\hline EU27 & 32 & 34 & 40 & 23 & 17 & 16 & 12 & 13 & 10 & 14 & 3 & 3 \\
\hline Latvia & 27 & 34 & 34 & 23 & 15 & 12 & 9 & 12 & 7 & 22 & 3 & 5 \\
\hline \multicolumn{13}{|l|}{2015} \\
\hline EU28 & 31 & 37 & 37 & 16 & 18 & 16 & 12 & 12 & 11 & 18 & 3 & 3 \\
\hline Latvia & 21 & 40 & 30 & 15 & 16 & 14 & 10 & 14 & 7 & 27 & 5 & 4 \\
\hline \multicolumn{13}{|l|}{2017} \\
\hline EU28 & 33 & 33 & 40 & 22 & 13 & 16 & 12 & 15 & 12 & 16 & 4 & 3 \\
\hline Latvia & 27 & 40 & 33 & 20 & 20 & 18 & 10 & 13 & 7 & 28 & 3 & 4 \\
\hline \multicolumn{13}{|l|}{2019} \\
\hline EU28 & 35 & 34 & 42 & 22 & 14 & 17 & 13 & 15 & 12 & 16 & 4 & 2 \\
\hline Latvia & 30 & 44 & 31 & 18 & 16 & 18 & 10 & 15 & 7 & 28 & 4 & 4 \\
\hline
\end{tabular}

Source: EC 2007, 32; 2013, 54; 2015, 89; 2017, 68; 2019a, 74. 


\begin{tabular}{|c|c|c|c|c|c|c|c|c|c|c|c|c|}
\hline 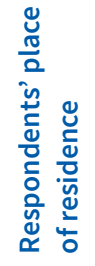 & 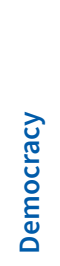 & 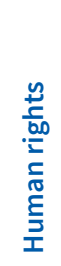 & 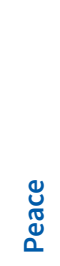 & 㝋 & 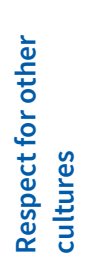 & 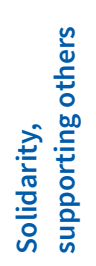 & 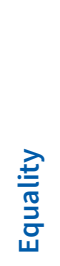 & 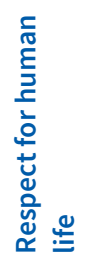 & 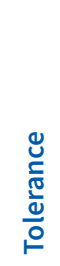 & 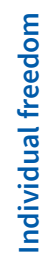 & 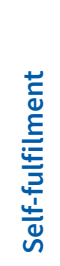 & $\frac{.0}{\frac{0}{00}}$ \\
\hline \multicolumn{13}{|l|}{2006} \\
\hline EU25 & 24 & 41 & 52 & 17 & 11 & 14 & 18 & 43 & 19 & 22 & 11 & 7 \\
\hline Latvia & 15 & 48 & 51 & 13 & 14 & 10 & 18 & 43 & 13 & 35 & 15 & 6 \\
\hline \multicolumn{13}{|l|}{2013} \\
\hline EU27 & 26 & 41 & 39 & 18 & 11 & 17 & 21 & 37 & 16 & 24 & 9 & 5 \\
\hline Latvia & 16 & 44 & 39 & 8 & 14 & 12 & 17 & 40 & 9 & 33 & 7 & 5 \\
\hline \multicolumn{13}{|l|}{2015} \\
\hline EU28 & 25 & 40 & 45 & 13 & 9 & 18 & 20 & 36 & 17 & 27 & 9 & 6 \\
\hline Latvia & 13 & 41 & 53 & 10 & 11 & 11 & 14 & 38 & 9 & 38 & 5 & 7 \\
\hline \multicolumn{13}{|l|}{2017} \\
\hline EU28 & 28 & 42 & 45 & 18 & 9 & 15 & 20 & 36 & 16 & 24 & 8 & 6 \\
\hline Latvia & 14 & 48 & 51 & 10 & 19 & 8 & 12 & 37 & 8 & 39 & 8 & 5 \\
\hline \multicolumn{13}{|l|}{2019} \\
\hline EU28 & 29 & 42 & 45 & 17 & 9 & 15 & 21 & 36 & 16 & 26 & 8 & 6 \\
\hline Latvia & 15 & 51 & 44 & 12 & 15 & 12 & 14 & 15 & 9 & 40 & 6 & 5 \\
\hline
\end{tabular}

Source: EC 2007, 30; 2013, 51; 2015, 81; 2017, 61; 2019a, 67).

can be assumed that this ranking reflects the experience of life under totalitarianism and the large share of ethnic minorities in the total composition of Latvia's inhabitants, which has promoted co-existence and mutual respect for diverse cultures. Such values as democracy, tolerance, rule of law, solidarity, and equality are less important for Latvia's people compared to "the average European" (Table 2.4.2.). To a large extent, these indicators signal insufficient Europeanization in these areas, deficiencies in national politics and weak sectors, as well as unconvincing communication of these values in public space. The existing social inequality among the population, poverty and social exclusion, lack of unity among social groups differing in terms of their status and material advantages (more extensively about this topic see Bela \& N̦ikišins, 2018) have not reinforced solidarity and equality as European values. Likewise, since restoration of the state, Latvian politics lacks convincing advocates of ideas of social democracy who would genuinely (that is, not in selfish political or financial interests or in the interests of some economic groups) propose the values of social justice, solidarity, and equality. The same must be said about the rule of law, the helplessness of which in the face of large-scale embezzlement of state and municipal resources and corruption has debased these values in Latvian public thinking.

Data from the Eurobarometer study lead to additional questions about the place of democracy in the scale of values of Latvia's people: is it really so low? Can the existence of democracy be assessed and measured, and what does it offer to the individual? Is the concept of "democracy" understood in Latvia in the same way as elsewhere in Europe? Throughout Europe, democracy is the result of long historical development. When looking at the relationship between power and society, it is clear that "the more equal, extensive, protected and mutually binding the State's consultations with its people are, the more democratic a political regime is" (ljabs, 2018, 120). Looking at the initial state of EU enlargement, it must be admitted that the Baltic States were viewed as the European region with the weakest tradition of civil society and democracy because its institutions had formed comparatively late and had existed only for a short time in the interwar period (Delanty, 2019, 262). 
Figure 2.4.5. Comparison of responses by age group of Latvia's inhabitants to the question: "In your opinion, is democracy a value in Europe?"

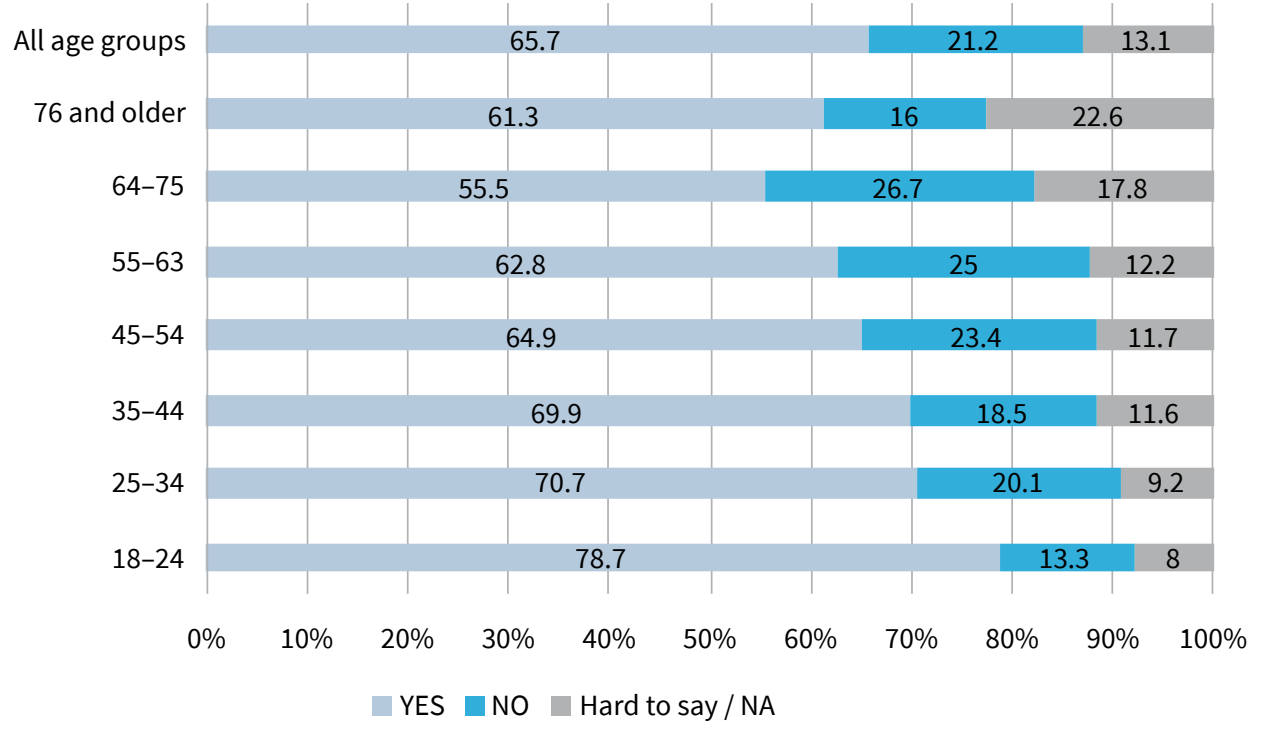

Source: HDR Survey 2020

Currently, fully-fledged European democracy, although to a certain extent riddled with deficiencies and drawbacks, does exist in Latvia (more about the topic see Rozenvalds, 2005, 2007, 2014), and in many parameters should be assessed higher than in several other new EU Member States. In the global democracy index of 2019 , Latvia, with its score of 7.49 , ranked a high $38^{\text {th }}$ (among 167 countries). The lowest assessment was given to the functioning of the government and administration (6.07 points), and the level of political participation (6.11), with the highest to the election process and pluralism (9.58), while assessment of civil freedoms is also noteworthy (8.82) (The Economist Intelligence Unit, 2019, 11). Often, the problems of Latvia's democracy are linked exactly to the large share of non-citizens, a consequence of the period of Soviet occupation which has not been entirely overcome since restoration of statehood. It is citizenship that ensures an individual's link to the state and inclusion in the political community.

In a Latvian population survey conducted in 2020 , $65.6 \%$ of respondents answered "yes" and only $26.1 \%$ with "definitely yes" to the simple question: "In your opinion, is democracy a value in Europe?", while 21.2\% of respondents answered negatively and $13.1 \%$ gave no answer. Differences were also observed in terms of age groups and education. Groups of elderly respondents expressed greater scepticism regarding democracy as a European value; likewise, members of these groups tended to avoid answering the question (Figure 2.4.5.). These data are consistent with the outcomes of a survey conducted by SKDS in July 2019, regarding satisfaction with the functioning of democracy in Latvia. They show that $41 \%$ of respondents are satisfied (only $4 \%$ totally satisfied), whereas $47 \%$ are dissatisfied (12\% totally dissatisfied), and $11 \%$ are unable to answer the question. The highest indicator of satisfaction is in the 18-24 age group (55\%), but the lowest in the $64-75$ age group (32\%) (SKDS 2019a).

In other cross-sections, too, the outcomes of the 2020 survey show that several problematic areas can be observed in relation to democracy as a European value. Many individuals with a low level of education do not consider it to be a European value or are unable to answer the question (Figure 2.4.6.). The answers to this question also mark the dividing line between Latvian citizens and non-citizens, citizens of other countries residing in Latvia, as well as between people whose language of communication in the family is either Latvian or Russian (Figure 2.4.7.). The relationship of Latvia's Russian-speaking inhabitants as a social group with Latvian citizenship and the consequences of the impact of the post-Soviet period upon that relationship can be mentioned as the causes for this. Uncertainty regarding democracy as a value, which determines not only state policies and the functioning of its institutions but also individuals' daily lives, their possibilities for self-fulfilment and individual freedom, causes populism and the threat that a longing might flourish for an authoritarian strong arm. In a survey of Latvia's population conducted by SKDS in February 2019, 64\% of respondents upheld the statement "To improve the situation in the state, Latvia needs one strong leader with extensive powers", while $30 \%$ of respondents did not uphold this statement and $6 \%$ did not provide an answer. A high number of those supporting a strong leader was also observed in previous years. It was the highest in 2011 
Figure 2.4.6. Comparison of responses by Latvia's inhabitants with different levels of education to the question: "In your opinion, is democracy a value in Europe?"

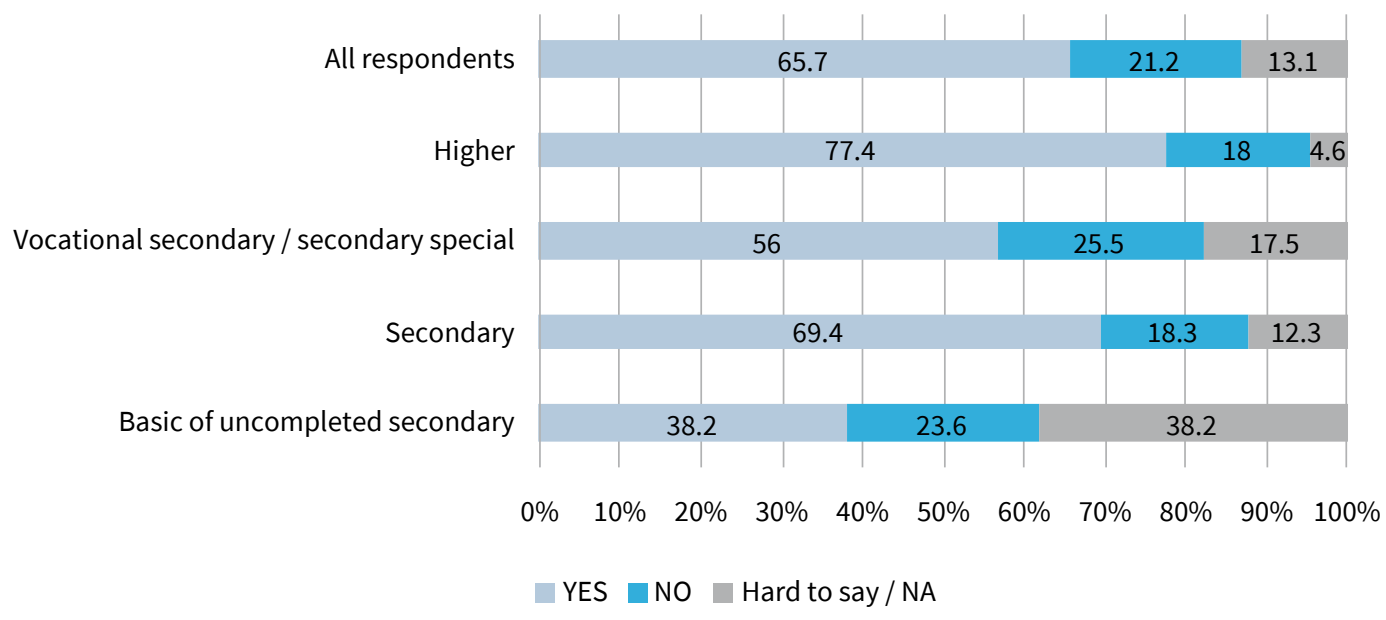

Source: HDR Survey 2020.

Figure 2.4.7. Comparison of the answers by social groups of Latvia's inhabitants to the question "In your opinion, is democracy a value in Europe?"

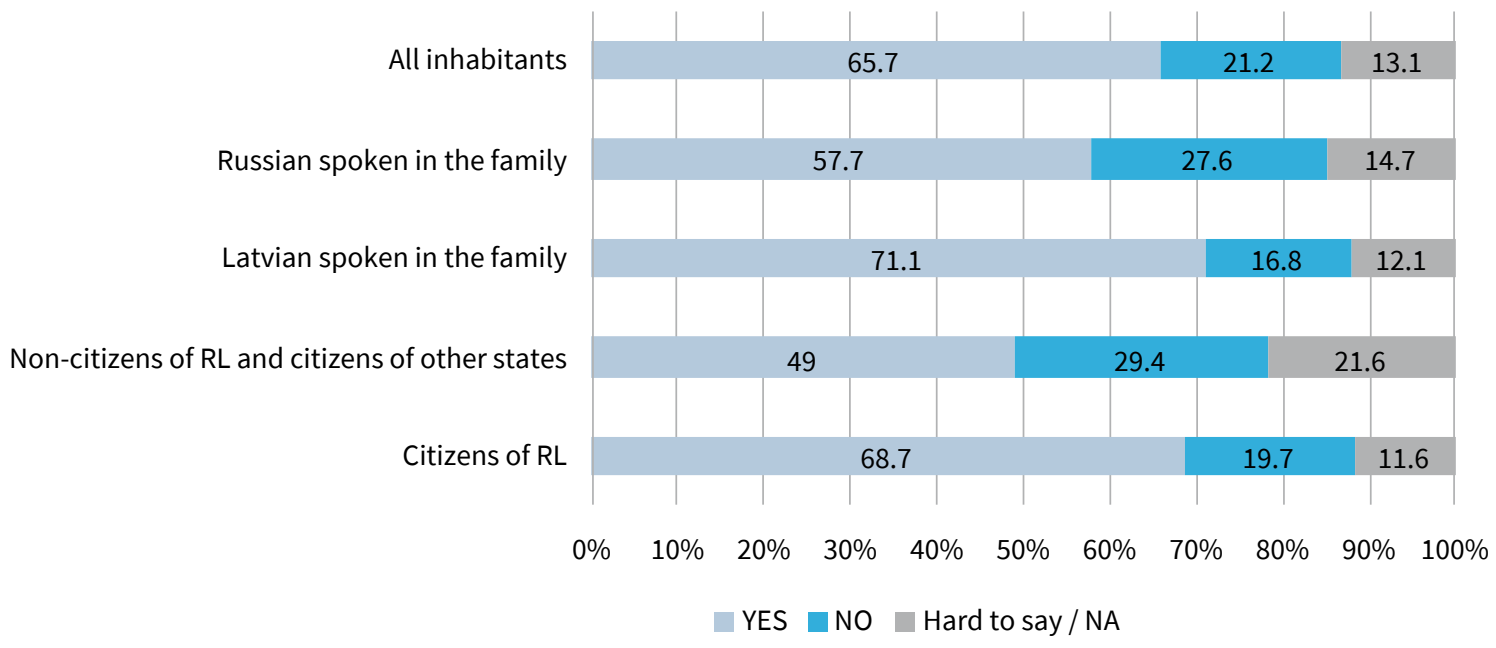

Source: HDR Survey 2020.

when $73 \%$ of respondents upheld the statement (SKDS 2019b).

The diverse sociological research data examined in this section suggest that a large part of Latvian society has lost its way in definitions and understanding of European values and democracy and in ascribing these to their own lives and possibilities for self-fulfilment. Perhaps the causes can be found in passive direct participation in the development of the state and its policies as well as in education and culture, inter alia, in an insufficient understanding of the possible and actual scenarios for an individual's own life in a democratic state and within an authoritarian regime, which, as the survey outcomes referred to above show, many find attractive. Of course, an understanding of democracy is formed in schools, but for many this is the first and last serious education in these matters. European values are seldom represented in public space and local cultural output attracts a large audience. Hence there is no motivation, based on knowledge and understanding of democracy, to engage in developing and improving one's own state and institutions. The civil initiative "Democracy Week", organised in 2020 by "Civic Alliance-Latvia", an advocacy organisation from the non-governmental sector, 
seems to be promising. Online events, including interactive ones, were held during the week, with participation in events offered through social networks. The initiative also included establishing Mikselis Valters Day, named after a democratic Latvian politician and representative of democratic values, to educate society and hold discussions about the history and future of Latvia's democracy. Values and symbols of democracy are scarcely promoted in contemporary Latvian public space and in stories about history. For example, the gallery of personalities embodying its values is rather scanty, often beginning and ending with the name of Jānis Čakste, the first President of the Republic of Latvia, so establishing Mikelis Valters' Day is a good step towards expanding it. The factors that facilitate understanding European values and democracy and thus, too, their embodiment in daily life, should be sought in improving the administration, developing the NGO sector and civil society, as well as in culture, for example various media products offering emotionally effective embodiment of these values.

\section{Post-material values}

In the 1980s and 1990s, slogans about returning to Europe and striving for full membership in the EU in Latvia were linked to a passionate wish to become a welfare state and reach a West European standard of living. During the period since restoration of independence, a significant increase towards prosperity has occurred, although Latvia continues to be among the poorest EU states and lags behind "old" Europe. In the Western world, in turn, values orientation is tending to shift away from those of material welfare and to strive for other values - attesting to quality of life and individual self-fulfilment. Several generations who have not experienced hunger, economic collapse and extreme social vulnerability have grown up in post-war Europe. So, for them, simple material welfare and its acquisition as a value in the context of human life is becoming partially meaningless. Other - that is, post-material values are becoming more important for individuals (Inglehart, 2009, 225). These comprise aesthetic and intellectual values, characterised, for example, by natural and urban beauty, the volume of ideas created and implemented, freedom of speech, affiliation and respect, as well as successful self-fulfilment. Opportunities for individuals to participate in resolving issues in their workplace and home and involvement in adoption of important national decisions fall within the system of post-material values. These are slowly taking root in the prosperous Western democratic countries, too, as it takes decades for welfare to become habitual and a self-evident component of the way of life (Dalton, 2020, 92-96).

The place of post-material values in Latvia's overall value system characterises the outcomes of Europeanization of Latvian society. In 1998, when
Latvia was already on its way towards joining the EU, a study was conducted that led to the conclusion that three-fourths of Latvia's population strictly stood up for material values. This attitude is rooted in the low welfare level of society at the time and a desire to alleviate that situation. Among Latvian citizens, 18\% (and $17 \%$ of non-citizens) recognised involvement in state decisions as the most important. Freedom of speech was at the top of the scale only for $4 \%$ of citizens and non-citizens ([s. n.] 1998). More recent studies reveal that post-material values are gradually taking root in the life of Latvian society. On the basis of data from a survey conducted in 2016 , the conclusion was that $12.3 \%$ of Latvia's inhabitants should be regarded as "pronounced materialists", $35.5 \%$ as "slightly materialistic", $12.9 \%$ as "slightly post-materialist" and $1.6 \%$ as "post-materialists". Rather many $(37.7 \%)$ of respondents cannot be included in any of these groups. Data show that elderly people belong more pronouncedly to the materialists, but even in groups of young people materialists prevail over post-materialists (Mierina, 2018, 68).

The question asked in the 2020 survey - "In your opinion, is the European landscape - cities and countryside - well-maintained and beautiful?" - reveals the way Latvia's inhabitants view post-material values. The answers encourage reflections on the value of landscape aesthetics and the human role in shaping it. The radical difference in terms of the aesthetic image and appearance of cities and the countryside between the communist and Western worlds was one of the most obviously pronounced differences, and the gradual elimination thereof is one of the aims set for practical action in post-Soviet society. Therefore the high aesthetics of the Western landscape motivated Latvia's inhabitants to put in order the urban and rural environment around them. Noteworthy success has been achieved in this area, in particular in the regions. The majority of Latvia's people surveyed affirmed that European cities and countryside were well-maintained and beautiful. Moreover, it was easier for them to answer this question and uncertainty in opinions is not identified, unlike in those cases when an opinion is expressed on matters of history or a question touches on democracy as a value. No pronounced difference is observed in positions among diverse social demographic groups. For example, unanimity is quite large in terms of age (Figure 2.4.8.) A slightly more discernible difference can be identified in persons belonging to families speaking Latvian and those speaking Russian. In families where Latvian is spoken, $87.8 \%$ of respondents consider the European landscape to be well-maintained and beautiful, $8 \%$ of respondents consider that this is not the case while $4.2 \%$ cannot answer the question. In Russian-speaking families, these three indicators were, respectively $83.5 \%, 12.4 \%$, and $4.1 \%$. This suggests that Latvia's people place environmental aesthetics higher within their system of values than the historical heritage and the political and human rights framework of life. 
Figure 2.4.8. Comparison of responses by various age groups of Latvia's inhabitants to the question: "In your opinion, is the European landscape - cities and countryside - well-maintained and beautiful?"

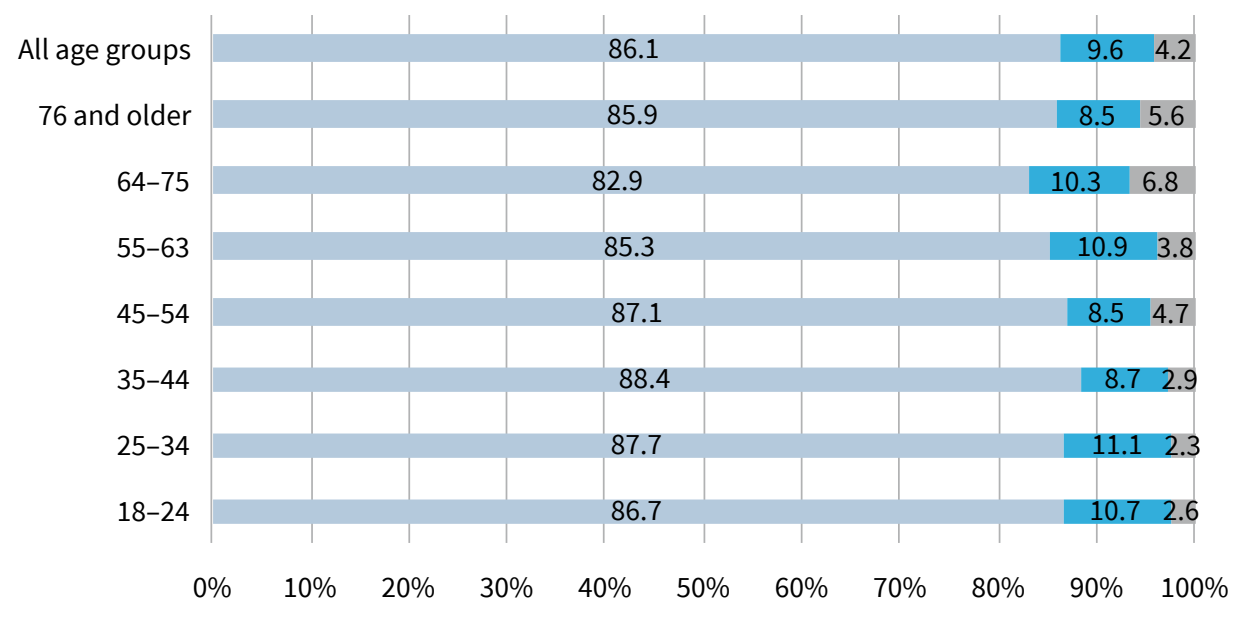

$\square$ YES NO $\square$ Hard to say / NA

Source: HDR Survey 2020

The embeddedness of post-material values is characterised by voluntary shared activities that are not aimed at gaining material benefit. In Latvia, the "Big Clean Up" movement is being successfully implemented, aimed at achieving a better-maintained - and thus also more beautiful - environment. Growing involvement of people in this movement is observed. "The Big Clean Up", finding new forms, was also successful while restrictions on gatherings during the spread of Covid-19 were in force.

The prevailing significance of leisure time, family, and friends over work and career characterises the post-materialistic worldview. In a survey of working-age (18-55) inhabitants of Latvia conducted in February 2019 by SKDS, $30 \%$ of respondents affirmed that work and career were most important for them, whereas family was more important for $61 \%$, while $9 \%$ of respondents could not answer the question. In 2001, for $42 \%$ of respondents work and career were more important, but the family for $43 \%$, with $14 \%$ of respondents unable to answer (SKDS, 2019c). Work has always been of particular importance in the tradition of European values because, thanks to that, the common welfare of the continent and the welfare of each individual has developed and increased. However, in recent decades a decrease in ranking of work as the most important value and an increase in the value of family and friends is observed in the highly developed welfare state.

New assistance, solidarity and collaboration practices by individuals and social groups came to life during the emergency situation caused by Covid-19, for example the \#paliecmājās, network of volunteers, who offered free of charge assistance in delivering food and household goods as well as in walking pets and providing emotional support (LSM.Iv News Editorial Board, 2020). Respect and appreciation were the motivation and remuneration for the volunteers' work.

The embodiment of post-material values is also observed in many other dimensions of human life the objective of which is just to let an individual lead a good life, to enjoy human dignity, to find self-fulfilment, intellectual enrichment and see to it that future generations will inherit the Earth in as good condition as possible. These trends are also becoming more pronounced in the system of values and way of life of Latvian society.

\section{Conclusion}

Are the people of Latvia aware of their belonging to Europe and the EU? Can it be said that Europeanization has indeed not only established European norms and practices but also an assurance of Latvia's own value in the unity of EU states? When Latvia set out on its path towards statehood and thus also to Europe, poet Imants Ziedonis especially underscored that self-respect had to be regained, not only in individual and national terms but also on the international level. He wrote: "The rule that a person with self-respect gains respect is always in force. It applies to the nation as a whole." (Ziedonis 1999[1988], 286)

The answers provided by Latvia's inhabitants to the rhetorical question: "In your opinion, is Latvia a European value?" show that, in general, self-respect exists; however, one cannot maintain that its level would be very high, with $24.3 \%$ of respondents answering 
Figure 2.4.9. Comparison of responses by age groups of Latvia's inhabitants to the question: "In your opinion, is Latvia a European value?"

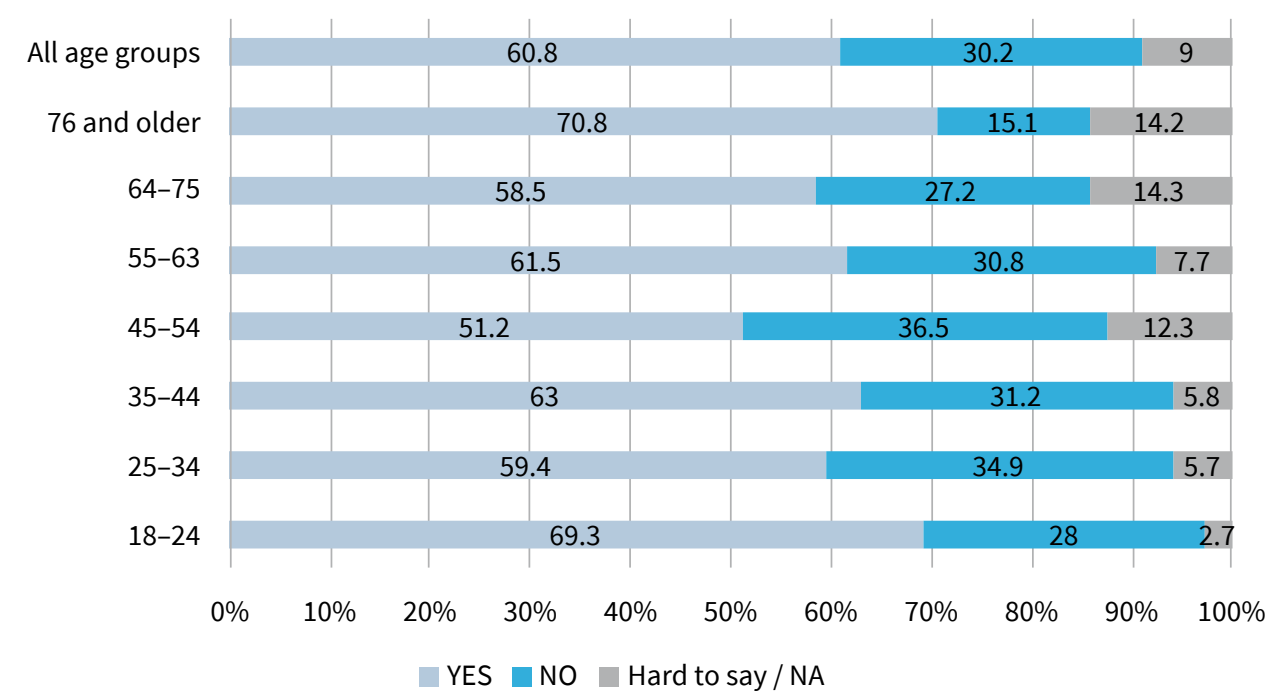

Source: HDR Survey, 2020.

Figure 2.4.10. Comparison of responses by social groups of Latvia's inhabitants to the question: "In your opinion, is Latvia a European value?"

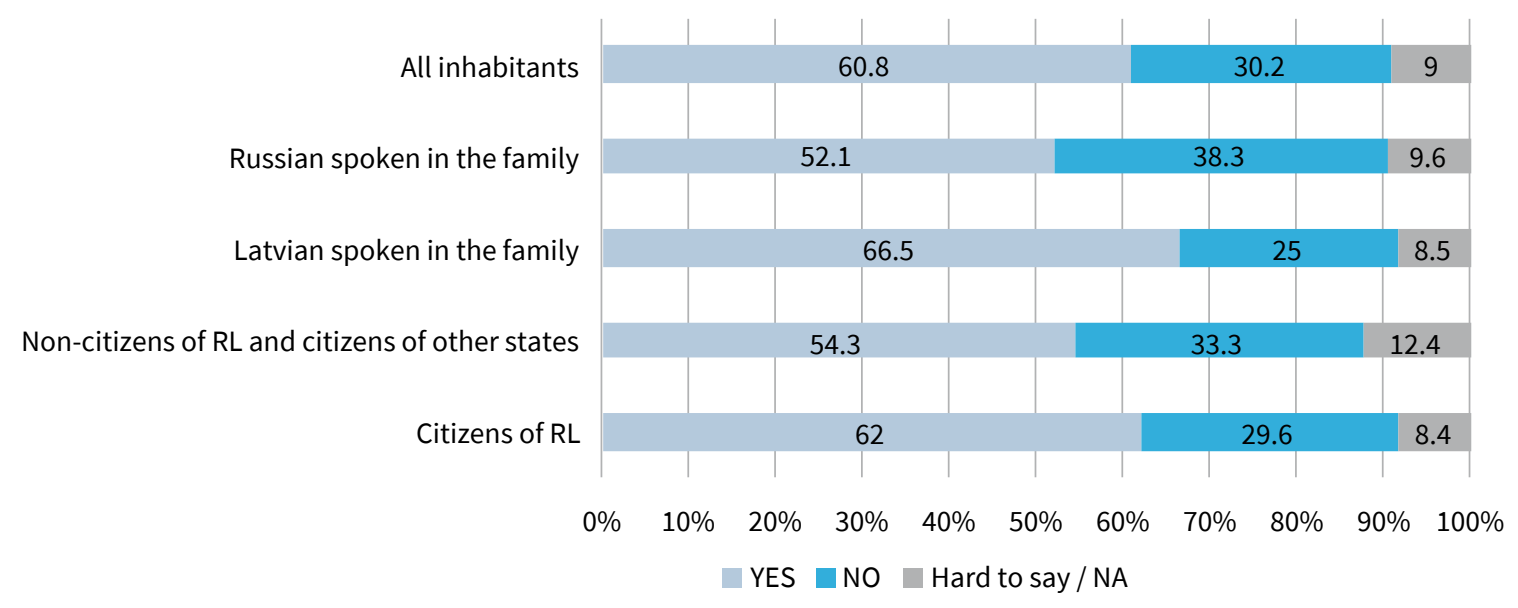

Source: HDR Survey, 2020.

with a definite "yes", "yes, somewhat" (36.5\%), but only $7.8 \%$ definitely saying "no", and $22.4 \%$ "no, somewhat" and $9 \%$ of those surveyed having no answer. Viewed from the perspective of the respondents' age group, it must be said that those belonging to the youngest and the oldest groups consider Latvia to be a European value (Figure 2.4.9.). The level of collective self-respect is higher in Latvian-speaking rather than Russian-speaking families (Figure 2.4.10.). Comparatively more women recognise Latvia as a European value (63.5\% of respondents) while $57.8 \%$ of men surveyed answered with a definite "yes" and "yes, somewhat".

Formal and informal Europeanization is one of the most important tools that shape the relationship of Latvia's society with Europe as a cultural-geographical category and the EU as a political, economic, social and cultural category. Formal integration in the EU, doing accession homework and thereafter performing and routinizing regular tasks and obligations has also furthered the general progression of Europeanization. 


\section{Major achievements}

Welfare attained is the foundation for success in the Europeanization of Latvian society and the embodiment of the European way of life. The pre-conditions for transformation of human identity, attitudes and conduct from the Soviet to the European model as well as a pre-condition for the recognition and (more importantly) embodiment of tolerance, respect for human rights, democracy, peace and other values are leaving behind extreme poverty and need, and achieving a standard of living that complies with human dignity. Only a person who is materially wellprovided for and secure can live life to its fullest and embody the European system of values in their life.

During recent decades, the lessons of European history and values have become integrated into the collective memory and understanding of history. Schools, cultural institutions and the media have played a major role in this process. The history of crimes perpetrated by the communist regime has been included in the common space of European history and commemorative rituals.

The attitude of Latvia's peoples towards European values allows assessing the successes of Europeanization. Human rights, peace and individual freedom are the main European values ranked highest in Latvia. Post-material values are noticeably but gradually becoming embedded in Latvian society, which is important for the sustainability of Europeanization.

\section{Most important tasks}

The continuing marked social inequality, alienation, poverty and instability of welfare are threats to the successful process of Europeanization in Latvia. European values can be implemented and enjoyed only in a prosperous state.

Problems are caused by an insufficient rational appreciation of the embodiment of European values in human lives, sympathies towards authoritarianism and emotional nostalgia for the Soviet order. Understanding European values is allocated a minor role in education, the media and cultural output.

Promoting the welfare of Latvian society, alleviating social injustice, isolation and poverty, abiding by the requirements of justice and honesty in national politics.

Developing national history and memory policy on the basis of human rights as a priority. More extensive and active embodiment of the advantages of European values and democracy in culture and media products. Promotion of post-material values, in particular human dignity, appreciation, quality of environment and life. Promoting the selfrespect of Latvia's people as Europeans through education, culture and identity policy. 


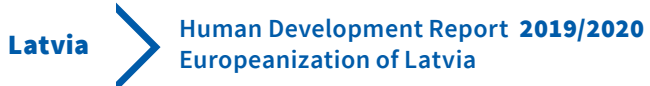

\section{Appendicies}




\section{Latvia's Human Development Report social survey: technical information}

Aim of the study: to obtain sociological survey data residents' of Latvia attitude and values for scientific research and the needs of Latvia's Human Development Report.

Study conducted by: "Pētījumu centrs SKDS” (32- 2 Baznīcas iela, Riga, LV-1010, Latvia (+371) 67312876, skds@skds.lv).

Target group: Permanent residents of the Republic of Latvia above the age of 18.

Size of the planned sample: 1,000 respondents

Size of the obtained sample: 1,000 respondents (a representative sample of the general population).

Data collection method: phone interviews (CATI).

Sampling method: random generating of phone numbers (Random Digit Dialing (RDD)).

Research instrument: survey questionnaire in Latvian and Russian prepared and approved by the customer.

Geographical coverage: Residents of Latvia, on the basis of the data from the Population Register of the Office of Citizenship and Migration Affairs of the Ministry of the Interior of the Republic of Latvia (PR OCMA MO RL) (as of 27 January 2020) and breakdown according to sociodemographic characteristics.

Time of conducting survey: from 15 May 2020 to 24 May 2020.

\section{Description of the sample and the interviewing procedure}

Procedure of obtaining phone numbers

- Randomly selected landline and mobile phone numbers were obtained by using the online random.org.

Description of CATI procedure

- When calling mobile phone numbers, the person who took the call was surveyed.

- When calling landline phone numbers, an adult whose birthday was the closest was invited for the phone interview. If the selected person was not at home, the interviewer clarified when the respondent would be at home. Call was repeated until the selected person was reached.

\section{Description of field work}

Period of field work: the field work or data collection proceeded from 15 May 2020 till 24 May 2020.

\begin{tabular}{cc}
\hline Number of interviewers & 18 \\
\hline Total number of contacts & 3,133 \\
\hline Number of interviews conducted & 1,000 \\
\hline Total number of refusals & 2,133 \\
\hline Number of unreached respondents & 6,816 \\
\hline Average length of an interview & 14 min. 43 sec. \\
\hline Longest interview duration & 50 min. $17 \mathrm{sec}$. \\
\hline Shortest interview duration & 5 min. $44 \mathrm{sec}$. \\
\hline
\end{tabular}




\section{Comparison of the reached sample with the population statistics}

\begin{tabular}{|c|c|c|c|}
\hline & $\begin{array}{c}\text { Number of respondents } \\
\text { in the sample (\%) before } \\
\text { weighting }\end{array}$ & $\begin{array}{c}\text { Number of respondents } \\
\text { in the sample (\%) after } \\
\text { weighting }\end{array}$ & $\begin{array}{c}\text { Statistics (RL MI OCMA 2020) } \\
(\%)^{\star}\end{array}$ \\
\hline TOTAL: & 100.0 & 100.0 & 100.0 \\
\hline \multicolumn{4}{|l|}{ GENDER } \\
\hline Males & 46.0 & 46.1 & 46.1 \\
\hline Females & 54.0 & 53.9 & 53.9 \\
\hline \multicolumn{4}{|l|}{ AGE } \\
\hline $18-24$ years & 7.1 & 7.5 & 7.5 \\
\hline $25-34$ years & 16.2 & 17.4 & 17.4 \\
\hline $35-44$ years & 17.8 & 17.3 & 17.3 \\
\hline $45-54$ years & 17.8 & 17.0 & 17.0 \\
\hline $55-63$ years & 16.3 & 15.6 & 15.6 \\
\hline $64-75$ years & 14.3 & 14.6 & 14.6 \\
\hline 76 years and older & 10.5 & 10.6 & 10.6 \\
\hline \multicolumn{4}{|l|}{ ETHNICITY } \\
\hline Latvians & 60.8 & 58.8 & 58.8 \\
\hline Other & 39.2 & 41.2 & 41.2 \\
\hline \multicolumn{4}{|l|}{ REGION } \\
\hline Rīga & 34.3 & 33.5 & 33.5 \\
\hline Pierīga & 19.3 & 18.8 & 18.8 \\
\hline Vidzeme & 8.8 & 9.7 & 9.7 \\
\hline Kurzeme & 12.3 & 12.5 & 12.5 \\
\hline Zemgale & 11.9 & 11.7 & 11.7 \\
\hline Latgale & 13.4 & 13.8 & 13.8 \\
\hline
\end{tabular}

* Source: Data of the Population Register of OCMA MI RL, as of 27 January 2020. 


\section{Human Development Index and tables of statistical indicators}

The Human Development Index (hereafter - HDI) was first published in the 1990 Human Development Report. Since then, HDI has been a matter of major interest among politicians, journalists and scientists - its components as well as the method of calculation are subjects of discussions. The method for calculating HDI and the selection of indicators have been constantly updated since 1990 .

Detailed information about changes in the calculation of HDI is available here: http://hdr.undp.org/en/humandev.

The HDI is a composite indicator, which allows assessing the long-term progress in the three main directions of human development - health, education, and income. The HDI clearly shows that development is more than just economic growth.

Detailed information about the method for calculating HDI is provided here:

http://hdr.undp.org/sites/default/files/hdr2019_technical_notes.pdf.

The table shows how the method for calculating the HDI has changed over time.

\section{Table 1}

\begin{tabular}{|c|c|c|c|c|}
\hline \multirow{2}{*}{ HDR } & \multicolumn{3}{|l|}{ Indicators } & \multirow{2}{*}{$\begin{array}{l}\text { Method of } \\
\text { calculation }\end{array}$} \\
\hline & health & education & income & \\
\hline 1990 & \multirow{6}{*}{$\begin{array}{l}\text { Life } \\
\text { expectancy } \\
\text { at birth }\end{array}$} & $\begin{array}{l}\text { Proportion of literate persons in the age group } 25 \\
\text { and above }\end{array}$ & $\begin{array}{l}\text { Real GDP per } \\
\text { capita PPP \$ (log) }\end{array}$ & \multirow{5}{*}{ Arithmetic mean } \\
\hline 1991-1994 & & $\begin{array}{l}\text { (2/3) Proportion of literate persons among adults } \\
(1 / 3) \text { Average years of schooling }\end{array}$ & \multirow{2}{*}{$\begin{array}{l}\text { Real GDP per } \\
\text { capita PPP \$ } \\
\text { (adjusted) }\end{array}$} & \\
\hline 1995-1998 & & $\begin{array}{l}\text { (2/3) Proportion of literate persons among adults } \\
\text { (1/3) Proportion of attendees of all institutions of } \\
\text { education }\end{array}$ & & \\
\hline 1999 & & $\begin{array}{l}\text { (2/3) Proportion of literate persons among adults } \\
\text { (1/3) Proportion of attendees of all institutions of } \\
\text { education }\end{array}$ & \multirow{2}{*}{$\begin{array}{l}\text { Real GDP per } \\
\text { capita PPP \$ (log) }\end{array}$} & \\
\hline 2000-2009 & & $\begin{array}{l}\text { (2/3) Proportion of literate persons among adults } \\
\text { (1/3) Proportion of attendees of all institutions of } \\
\text { education }\end{array}$ & & \\
\hline 2010-2019 & & $\begin{array}{l}\text { (2/3) Average years of schooling } \\
(1 / 3) \text { Expected years of schooling }\end{array}$ & $\begin{array}{l}\text { Real GDP per } \\
\text { capita PPP \& (In) }\end{array}$ & Geometric mean \\
\hline
\end{tabular}

Until 2010, HDI was calculated as a simple arithmetic mean of the indicators that characterised health, education, and income. In 2010, retaining the three-dimensional structure of the index, new indicators in the areas of income and education were selected for calculating $\mathrm{HDI}$, and the method for calculating the index was changed - from the arithmetic to the geometric mean. The method of arithmetic mean for calculating the index allows compensating low achievements in one dimension by high achievements in another. The method for calculating the geometric mean diminishes the possibilities of replacement between the dimensions that constitute the index and provides a more adequate reflection of the Real situation.

Since 2013, HDI published in human development reports cannot be compared to indices published in the previous reports due to the different method of calculation.

In view of the differences in the method for calculating HDI and in the selections of indicators, we re-publish Latvia's HDI from the global human development report of 2019 - Human Development Report 2019. Human Development Index and its components). The full text of the report is available here: http://report.hdr.undp.org/. 


\section{Table 2. Human Development Report: Latvia}

\begin{tabular}{|c|c|c|c|c|c|c|}
\hline & $\begin{array}{c}\text { Human } \\
\text { Development } \\
\text { Report Ranking } \\
\text { (Human } \\
\text { Development Report } \\
\text { 2019) }\end{array}$ & $\begin{array}{c}\text { Human } \\
\text { Development } \\
\text { Index }\end{array}$ & $\begin{array}{l}\text { Life expectancy } \\
\text { at birth, years }\end{array}$ & $\begin{array}{l}\text { Mean years of } \\
\text { schooling }\end{array}$ & $\begin{array}{c}\text { Expected years } \\
\text { of schooling }\end{array}$ & $\begin{array}{c}\text { Real Gross } \\
\text { National Income } \\
\text { per capita } \\
\text { (2011 PPP \$) }\end{array}$ \\
\hline 2014 & 46 & 0.819 & 74.2 & 11.5 & 15.5 & 22,281 \\
\hline 2015 & 44 & 0.830 & 74.3 & 11.5 & 15.2 & 22,589 \\
\hline 2017 & 41 & 0.847 & 74.7 & 12.8 & 15.8 & 25,002 \\
\hline 2019 & 39 & 0.854 & 75.2 & 12.8 & 16.0 & 26,301 \\
\hline
\end{tabular}

To calculate HDI, internationally comparable data from the following sources of information are used:

- gross national income per capita - from the World Bank's database of development indicators;

- mean years of schooling and expected years of schooling - from the database of UNESCO Institute for Statistics (2019);

- life expectancy at birth - data from the 2011 Revision of World Population Prospects for 1950-2050.

Information published in the global Human Development Report 2019 shows that the value of Latvia's HDI has increased in the period from 1990 to 2018 every year, from 0.693 to 0.854 , with Latvia ranking the $39^{\text {th }}$ among 189 countries of the world.

The next table shows how the value of each HDI indicator has changed. This information has been taken from the publication Human Development Report 2019 and is not comparable to the information at the disposal of the Central Statistical Bureau. Life expectancy has increased, compared to 1990, by 6.2 years, mean years of schooling - by 5.3 years, but the expected years of schooling - by 3.3 years.

\section{Table 3}

\begin{tabular}{|c|c|c|c|c|c|}
\hline & $\begin{array}{c}\text { Life expectancy at } \\
\text { birth, years }\end{array}$ & $\begin{array}{c}\text { Expected years of } \\
\text { schooling }\end{array}$ & $\begin{array}{l}\text { Mean years of } \\
\text { schooling }\end{array}$ & $\begin{array}{c}\text { Real GDP per } \\
\text { capita (PPP } 2011 \$ \text { ) }\end{array}$ & $\begin{array}{c}\text { Human Development } \\
\text { Index }\end{array}$ \\
\hline 1990 & 69.0 & 12.7 & 7.5 & 10,081 & 0.693 \\
\hline 1995 & 68.6 & 11.6 & 8.8 & 6,147 & 0.673 \\
\hline 2000 & 70.6 & 14.2 & 9.4 & 8,518 & 0.732 \\
\hline 2005 & 71.8 & 15.6 & 10.4 & 12,870 & 0.784 \\
\hline 2010 & 73.0 & 15.0 & 11.5 & 13,793 & 0.802 \\
\hline 2011 & 73.3 & 15.0 & 11.5 & 14,293 & 0.805 \\
\hline 2012 & 73.6 & 14.8 & 11.5 & 14,724 & 0.814 \\
\hline 2013 & 72.2 & 15.5 & 11.5 & 22,186 & 0.808 \\
\hline 2014 & 74.2 & 15.2 & 11.5 & 22,281 & 0.819 \\
\hline 2015 & 74.3 & 16.0 & 11.7 & 22,589 & 0.830 \\
\hline 2017 & 74.7 & 15.8 & 12.8 & 25,002 & 0.847 \\
\hline 2018 & 75.2 & 16.0 & 12.8 & 26,301 & 0.854 \\
\hline
\end{tabular}

The tables of human development indicators have been prepared in accordance with the indicators defined by the United Nations Development Programme (UNDP). The following 18 statistical tables comprise information about the most important human development aspects. The tables reflect the most important indicators for characterising 
the social process: health, education, environment, employment, etc. Information of the Central Statistical Bureau is used, if necessary - also additional data obtained from ministries, Eurostat, and other international organisations.

The statistical information found in the tables was obtained by a methodology used internationally. Since 2000, definitions, methodology and classification of some indicators referred to in the tables have changed. Hence, information has been revised and data adjusted for the entire period. Data from sample surveys conducted by the Central Statistical Bureau and other institutions are used in the data tables. In the tables, where calculations of population are made, information for the period from 2000 to 2010 has been recalculated in accordance with the results of 2011 Census. Information in the tables is provided on the basis of the data that were at the disposal of the Central Statistical Bureau on 1 August 2020.

Table 4. Characteristics of human development

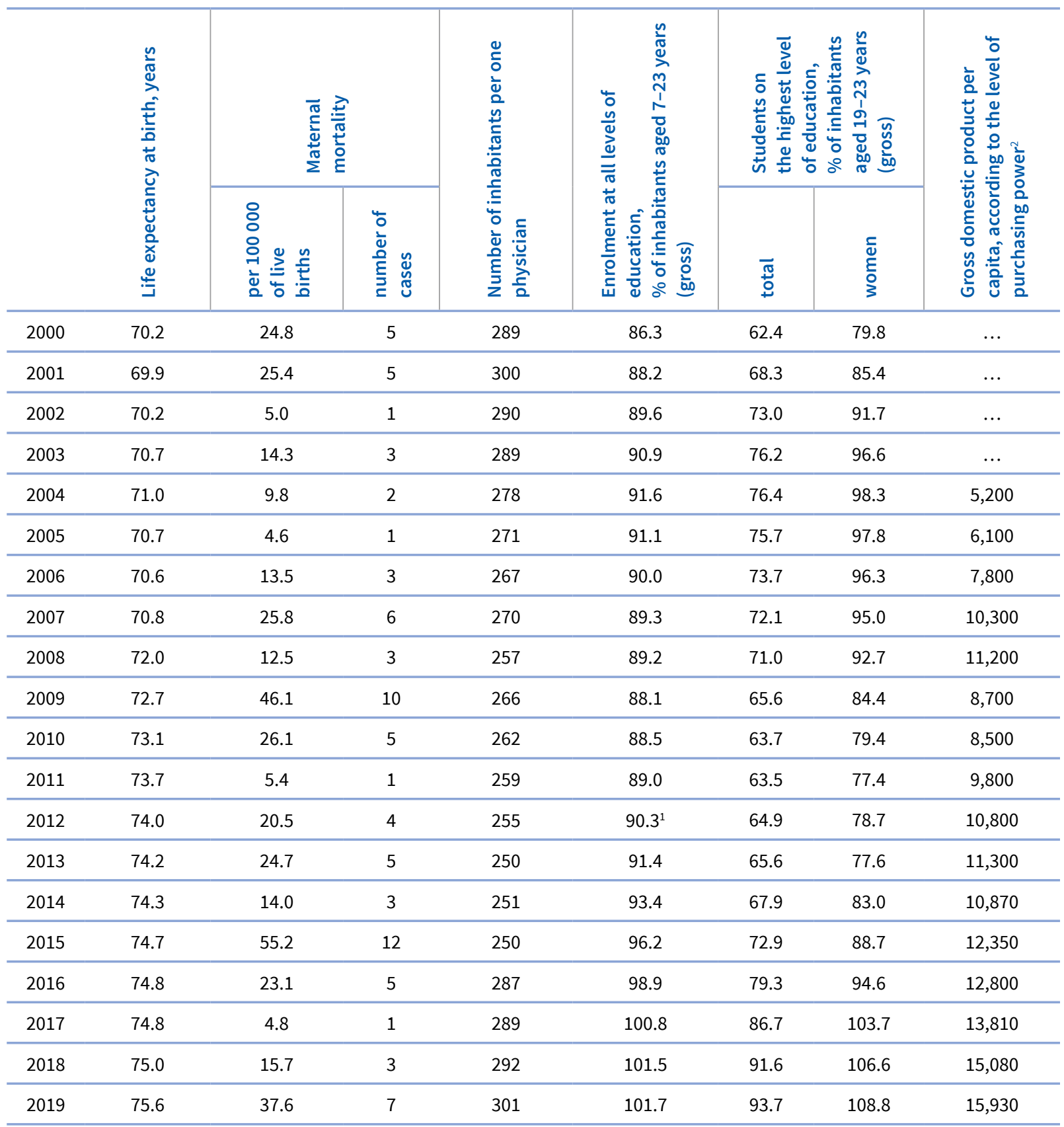

Data recalculated in accordance with the results of 2011 Census.

Data from Eurostat webpage:

https://ec.europa.eu/eurostat/databrowser/view/tec00001/default/table?lang=en.

Table: Gross domestic product at market prices.

Data for the period 2014-2017 updated. 


\section{Table $5 . \quad$ Human distress}

\begin{tabular}{|c|c|c|c|c|c|c|c|c|c|c|c|}
\hline & \multirow{2}{*}{ 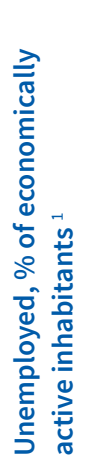 } & \multirow{2}{*}{ 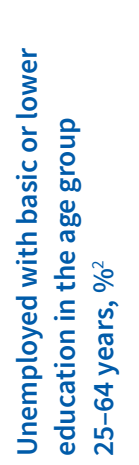 } & \multirow{2}{*}{ 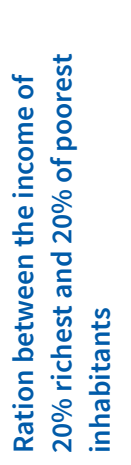 } & \multirow{2}{*}{ 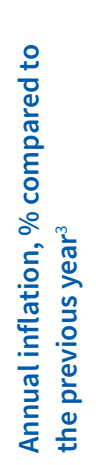 } & \multirow{2}{*}{ 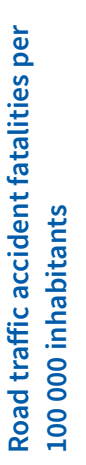 } & \multirow{2}{*}{ 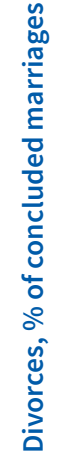 } & \multirow{2}{*}{ 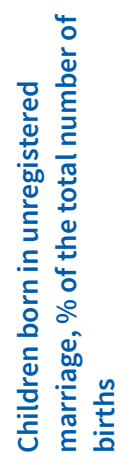 } & \multicolumn{2}{|c|}{ 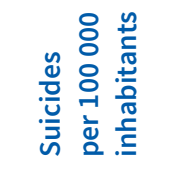 } & \multirow{2}{*}{ 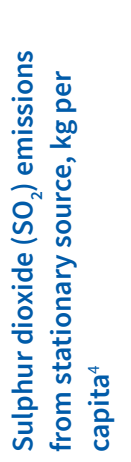 } & \multirow{2}{*}{ 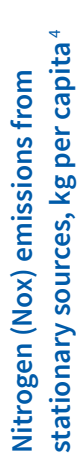 } \\
\hline & & & & & & & & Фّ & $\begin{array}{l}\text { Фे } \\
\text { छे } \\
\text { ○े }\end{array}$ & & \\
\hline 2000 & 7.8 & $\ldots$ & 5.5 & 102.6 & 25 & 66.6 & 40.4 & 56.3 & 11.8 & 5.1 & 3.5 \\
\hline 2001 & 7.7 & $\ldots$ & $\ldots$ & 102.5 & 22 & 62.0 & 42.1 & 52.3 & 11.2 & 3.8 & 3.7 \\
\hline 2002 & 8.5 & $\ldots$ & $\ldots$ & 101.9 & 22 & 61.1 & 43.1 & 49.0 & 12.0 & 3.3 & 4.0 \\
\hline 2003 & 8.6 & $\ldots$ & $\ldots$ & 102.9 & 22 & 48.3 & 44.3 & 45.8 & 9.8 & 2.6 & 4.5 \\
\hline 2004 & 8.5 & 15.9 & 6.7 & 106.2 & 23 & 50.8 & 45.3 & 43.7 & 8.6 & 2.0 & 3.9 \\
\hline 2005 & 7.4 & 14.2 & 7.8 & 106.7 & 20 & 50.6 & 44.7 & 43.1 & 9.8 & 1.4 & 4.3 \\
\hline 2006 & 6.5 & 12.7 & 6.4 & 106.5 & 18 & 49.6 & 43.8 & 39.9 & 6.7 & 0.9 & 4.8 \\
\hline 2007 & 4.9 & 9.4 & 7.3 & 110.1 & 19 & 47.8 & 43.2 & 35.3 & 7.9 & 0.8 & 4.7 \\
\hline 2008 & 7.0 & 13.0 & 7.4 & 115.4 & 15 & 48.0 & 43.2 & 42.4 & 8.4 & 0.5 & 3.7 \\
\hline 2009 & 16.0 & 26.5 & 6.8 & 103.5 & 12 & 51.4 & 43.5 & 41.9 & 8.5 & 0.5 & 3.4 \\
\hline 2010 & 14.3 & 29.1 & 6.5 & 98.9 & 10 & 53.1 & 44.4 & 39.1 & 5.4 & 0.7 & 4.0 \\
\hline 2011 & 11.5 & 27.5 & 6.5 & 104.4 & 9 & 77.2 & 44.6 & 38.8 & 6.7 & 0.5 & 4.1 \\
\hline 2012 & 10.5 & 22.9 & 6.3 & 102.3 & 9 & 65.0 & 45.0 & 39.6 & 6.6 & 0.5 & 4.5 \\
\hline 2013 & 9.5 & 22.6 & 6.5 & 100.0 & 9 & 61.5 & 44.6 & 34.8 & 5.6 & 0.3 & 4.4 \\
\hline 2014 & 8.5 & 23.6 & 6.5 & 100.6 & 11 & 50.1 & 44.0 & 34.0 & 6.6 & 0.3 & 4.1 \\
\hline 2015 & 8.7 & 22.4 & 6.2 & 100.2 & 10 & 37.8 & 41.5 & 33.6 & 7.6 & 0.2 & 4.4 \\
\hline 2016 & 8.4 & 19.8 & 6.3 & 100.1 & 8 & 46.6 & 40.9 & 31.9 & 7.3 & 0.2 & 4.4 \\
\hline 2017 & 6.8 & 18.3 & 6.8 & 102.9 & 8 & 45.2 & 40.4 & 31.7 & 6.7 & 0.2 & 4.8 \\
\hline 2018 & 6.4 & 17.0 & 6.5 & 102.5 & 9 & 45.7 & 39.5 & 29.4 & 3.7 & 0.2 & 4.9 \\
\hline 2019 & 6.2 & 13.3 & $\ldots$ & 102.8 & 8 & 46.4 & 38.4 & 25.7 & 6.0 & 0.3 & 4.9 \\
\hline
\end{tabular}

Data of the State Employment Agency (SEA): https://www.nva.gov.lv/lv.

2 Data from Eurostat webpage:

https://ec.europa.eu/eurostat/databrowser/view/tps00066/default/table?lang=en.

Table: Unemployment rate of the population aged 25-64 by educational attainment level.

3 Since 1 January 2016, to calculate the index of consumption prices, the harmonised index of consumer process, and harmonised indices of consumer prices at constant taxes, the European Classification of Individual Consumption according to Purpose (hereafter - ECOICOP) is used.

4 Information of the Latvian Environment, Geology and Meteorology Centre. 


\section{Table 6. Gender differences (females as \% versus to males)}

\begin{tabular}{|c|c|c|c|c|c|c|c|c|}
\hline & 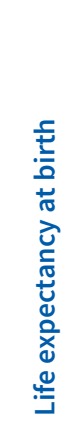 & 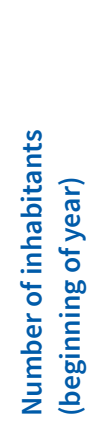 & 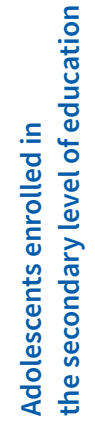 & 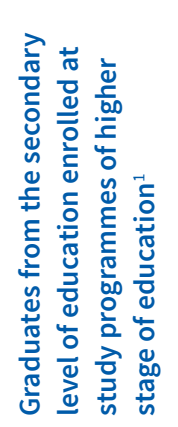 & 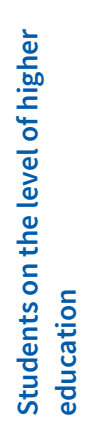 & 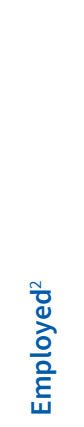 & 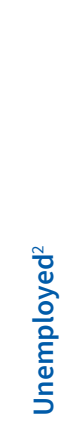 & 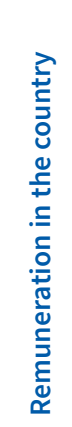 \\
\hline 2000 & 117.3 & 117.1 & 106.4 & 100.5 & 157.4 & 96.2 & 82.4 & 78.6 \\
\hline 2001 & 117.6 & 117.3 & 104.8 & 112.3 & 142.1 & 98.3 & 81.4 & 80.2 \\
\hline 2002 & 117.9 & 117.7 & 104.8 & 104.7 & 138.8 & 96.9 & 84.4 & 81.5 \\
\hline 2003 & 115.7 & 118.0 & 104.4 & 101.4 & 140.0 & 96.5 & 97.4 & 83.5 \\
\hline 2004 & 116.2 & 118.0 & 96.4 & 111.0 & 144.3 & 96.7 & 101.3 & 84.4 \\
\hline 2005 & 117.6 & 118.0 & 96.7 & 111.9 & 145.8 & 95.8 & 94.4 & 81.9 \\
\hline 2006 & 117.1 & 118.0 & 98.2 & 113.3 & 152.7 & 96.1 & 88.0 & 82.4 \\
\hline 2007 & 116.7 & 117.9 & 99.2 & 106.4 & 156.9 & 95.8 & 81.1 & 83.9 \\
\hline 2008 & 116.4 & 117.6 & 100.4 & 111.2 & 154.3 & 98.5 & 82.1 & 84.8 \\
\hline 2009 & 115.0 & 117.9 & 99.0 & 108.9 & 150.4 & 108.9 & 67.9 & 83.9 \\
\hline 2010 & 114.7 & 118.4 & 95.3 & 103.1 & 144.3 & 111.3 & 73.7 & 81.5 \\
\hline 2011 & 114.4 & 118.9 & 93.0 & 101.0 & 139.5 & 107.0 & 74.8 & 83.4 \\
\hline 2012 & 114.2 & 118.7 & 92.5 & 100.3 & 134.4 & 104.5 & 87.8 & 83.2 \\
\hline 2013 & 113.7 & 118.4 & 91.7 & 96.1 & 147.8 & 102.9 & 89.4 & 83.1 \\
\hline 2014 & 114.8 & 118.3 & 91.8 & 104.2 & 143.0 & 101.8 & 82.7 & 83.0 \\
\hline 2015 & 113.8 & 118.0 & 95.4 & 101.5 & 144.5 & 101.8 & 77.3 & 83.9 \\
\hline 2016 & 113.8 & 117.7 & 96.0 & 106.7 & 137.6 & 103.9 & 77.8 & 82.9 \\
\hline 2017 & 114.0 & 117.4 & 95.6 & 106.2 & 138.6 & 102.9 & 78.2 & 84.7 \\
\hline 2018 & 113.7 & 117.4 & 97.2 & 106.9 & 128.5 & 102.7 & 76.7 & 84.8 \\
\hline 2019 & 112.9 & 117.0 & 97.0 & $\ldots$ & 126.0 & 102.2 & 75.6 & 84.0 \\
\hline
\end{tabular}

Data for the period 2013-2017 updated.

2 Data of Labour Force Survey. In 2000-2001, persons 15 years old and older, since 2002 - 15-74 years old. 


\section{Table 7. Status of women}

\begin{tabular}{|c|c|c|c|c|c|c|c|c|c|c|}
\hline & \multirow{2}{*}{ 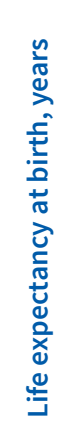 } & \multirow{2}{*}{ 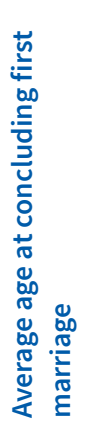 } & \multicolumn{2}{|c|}{ 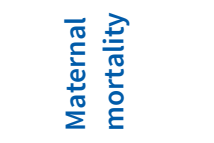 } & \multirow{2}{*}{ 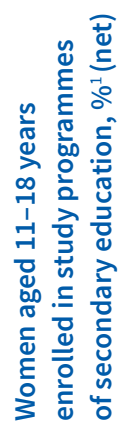 } & \multirow{2}{*}{ 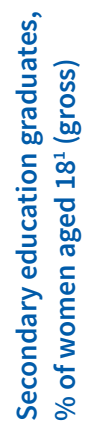 } & \multirow{2}{*}{ 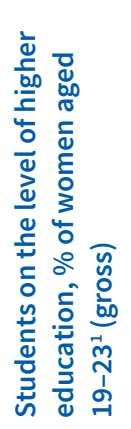 } & \multirow{2}{*}{ 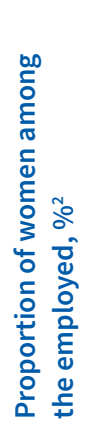 } & \multirow{2}{*}{ 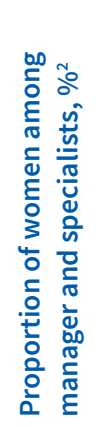 } & \multirow{2}{*}{ 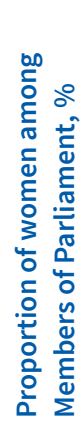 } \\
\hline & & & 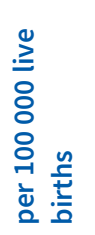 & 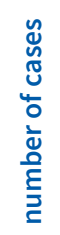 & & & & & & \\
\hline 2000 & 75.8 & 24.9 & 24.8 & 5 & 86.5 & 94.0 & 79.8 & 46.9 & 57.7 & $17^{3}$ \\
\hline 2001 & 75.5 & 24.9 & 25.4 & 5 & 87.7 & 92.7 & 85.4 & 48.0 & 59.4 & $17^{3}$ \\
\hline 2002 & 75.9 & 25.4 & 5.0 & 1 & 87.2 & 75.2 & 91.7 & 49.2 & 58.3 & $18^{4}$ \\
\hline 2003 & 75.7 & 25.4 & 14.3 & 3 & 88.9 & 70.7 & 96.6 & 49.7 & 57.7 & $18^{4}$ \\
\hline 2004 & 76.1 & 25.6 & 9.8 & 2 & 89.8 & 81.9 & 98.3 & 50.2 & 57.8 & $18^{4}$ \\
\hline 2005 & 76.3 & 26.0 & 4.6 & 1 & 89.1 & 85.1 & 97.8 & 50.8 & 58.7 & $18^{4}$ \\
\hline 2006 & 76.1 & 26.3 & 13.5 & 3 & 71.2 & 84.3 & 96.3 & 54.5 & 58.0 & $19^{5}$ \\
\hline 2007 & 76.2 & 26.4 & 25.8 & 6 & 71.3 & 84.5 & 95.0 & 56.3 & 60.8 & $19^{5}$ \\
\hline 2008 & 77.4 & 26.7 & 12.5 & 3 & 71.3 & 87.9 & 92.7 & 57.5 & 61.9 & $19^{5}$ \\
\hline 2009 & 77.6 & 27.1 & 46.1 & 10 & 70.0 & 87.4 & 84.4 & 52.9 & 60.9 & $19^{5}$ \\
\hline 2010 & 77.9 & 27.4 & 26.1 & 5 & 69.6 & 91.5 & 79.4 & 51.1 & 60.1 & $19^{6}$ \\
\hline 2011 & 78.5 & 27.7 & 5.4 & 1 & 68.1 & 90.2 & 77.4 & 52.1 & 60.5 & $19^{6}$ \\
\hline 2012 & 78.7 & 28.0 & 20.5 & 4 & 87.1 & 78.6 & 78.7 & 53.5 & 59.4 & $19^{6}$ \\
\hline 2013 & 78.8 & 28.5 & 24.7 & 5 & 84.4 & 75.6 & 77.6 & 55.3 & 58.9 & $19^{6}$ \\
\hline 2014 & 79.3 & 28.9 & 14.0 & 3 & 83.4 & 77.0 & 83.0 & 56.0 & 59.2 & $16^{7}$ \\
\hline 2015 & 79.3 & 28.7 & 55.2 & 12 & 82.8 & 77.7 & 88.7 & 57.8 & 60.7 & $16^{7}$ \\
\hline 2016 & 79.4 & 29.2 & 23.1 & 5 & 83.5 & 78.8 & 94.6 & 59.1 & 61.1 & $16^{7}$ \\
\hline 2017 & 79.6 & 29.5 & 4.8 & 1 & 82.9 & 76.3 & 103.7 & 60.1 & 63.5 & $16^{7}$ \\
\hline 2018 & 79.6 & 30.0 & 15.7 & 3 & 83.0 & 72.7 & 106.6 & 61.7 & 62.7 & $31^{8}$ \\
\hline 2019 & 79.9 & 30.6 & 37.6 & 7 & 82.6 & $\ldots$ & 108.8 & 62.3 & 62.8 & $31^{8}$ \\
\hline
\end{tabular}

1 According to the Regulation of the Cabinet of the Republic of Latvia "Regulations on the Classification of Latvia's Educational System"(11.04.2006.), as of 2007, the first stage of the secondary education includes Grades 7- 9 (13-15 years old), the second stage - Grades 10-12 (16-18 years old).

2 Data of Labour Force Survey. In 2000-2001, person from 15 years and older, as of 2002, 15-74 years old.

3 Results of the parliamentary election on 3 October 1998.

4 Results of the parliamentary election on 5 October 2002.

Results of the parliamentary election on 9 October 2006.

Results of the parliamentary election on 2 October 2010.

Results of the parliamentary election on 5 October 2014.

8 Results of the parliamentary election on 6 October 2018. 


\begin{tabular}{|c|c|c|c|c|c|c|c|}
\hline & \multirow{2}{*}{ 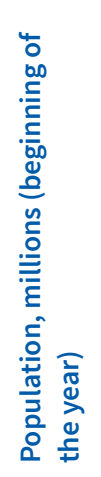 } & \multirow{2}{*}{ 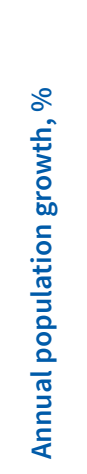 } & \multirow[b]{2}{*}{ 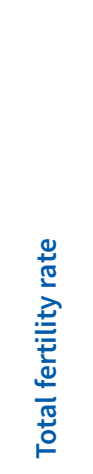 } & \multirow{2}{*}{ 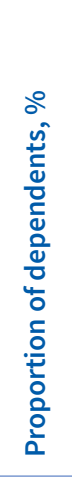 } & \multirow{2}{*}{ 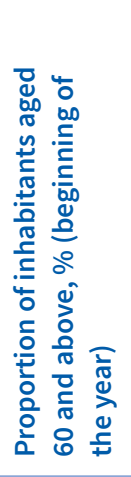 } & \multicolumn{2}{|c|}{ 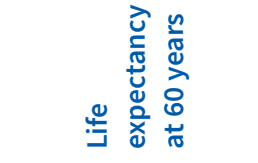 } \\
\hline & & & & & & $\frac{\stackrel{\mathscr{\varrho}}{\widetilde{N}}}{\stackrel{E}{\xi}}$ & 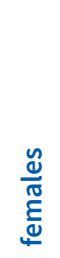 \\
\hline 2000 & 2.4 & -1.19 & 1.242 & 41.1 & 21.0 & 15.2 & 20.7 \\
\hline 2001 & 2.4 & -1.38 & 1.219 & 39.7 & 21.4 & 15.1 & 20.6 \\
\hline 2002 & 2.3 & -0.93 & 1.254 & 39.2 & 21.8 & 15.0 & 20.7 \\
\hline 2003 & 2.3 & -0.99 & 1.321 & 37.6 & 22.1 & 15.2 & 20.6 \\
\hline 2004 & 2.3 & -1.18 & 1.291 & 37.2 & 22.2 & 15.1 & 20.9 \\
\hline 2005 & 2.2 & -0.97 & 1.388 & 36.1 & 22.4 & 14.8 & 21.0 \\
\hline 2006 & 2.2 & -0.85 & 1.463 & 35.6 & 22.4 & 14.9 & 20.9 \\
\hline 2007 & 2.2 & -0.77 & 1.543 & 34.4 & 22.5 & 15.3 & 21.0 \\
\hline 2008 & 2.2 & -1.32 & 1.590 & 33.8 & 22.6 & 15.5 & 21.5 \\
\hline 2009 & 2.2 & -1.96 & 1.470 & 34.0 & 23.0 & 15.9 & 21.8 \\
\hline 2010 & 2.1 & -2.16 & 1.363 & 34.2 & 23.6 & 15.9 & 21.8 \\
\hline 2011 & 2.1 & -1.44 & 1.338 & 35.8 & 24.1 & 16.3 & 22.3 \\
\hline 2012 & 2.0 & -1.00 & 1.444 & 36.4 & 24.6 & 16.4 & 22.2 \\
\hline 2013 & 2.0 & -1.1 & 1.524 & 35.9 & 24.9 & 16.8 & 22.4 \\
\hline 2014 & 2.0 & -0.77 & 1.645 & 36.3 & 25.2 & 16.7 & 22.8 \\
\hline 2015 & 2.0 & -0.86 & 1.707 & 36.9 & 25.5 & 17.1 & 22.7 \\
\hline 2016 & 2.0 & -1.0 & 1.743 & 38.5 & 25.9 & 16.9 & 22.9 \\
\hline 2017 & 2.0 & -1.0 & 1.699 & 37.8 & 26.2 & 17.0 & 22.9 \\
\hline 2018 & 1.9 & -0.8 & 1.612 & 38.3 & 26.7 & 17.1 & 22.9 \\
\hline 2019 & 1.9 & -0.8 & 1.612 & 38.7 & 27.0 & 17.4 & 23.3 \\
\hline
\end{tabular}

Data for the period from 2000 to 2010 recalculated in accordance with the results of 2011 Census. 


\section{Table 9. Health indicators}

\begin{tabular}{|c|c|c|c|c|c|}
\hline & 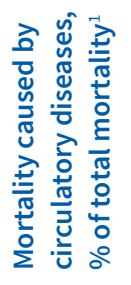 & 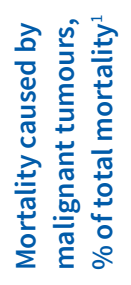 & 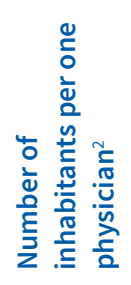 & 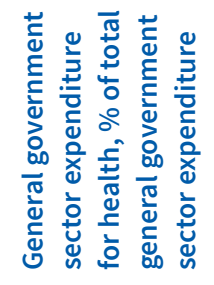 & 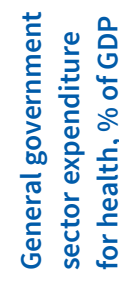 \\
\hline 2000 & 55.5 & 17.3 & 289 & 10.5 & 3.9 \\
\hline 2001 & 55.9 & 17.4 & 300 & 9.2 & 3.2 \\
\hline 2002 & 56.0 & 17.4 & 290 & 10.3 & 3.7 \\
\hline 2003 & 56.1 & 17.9 & 289 & 9.7 & 3.4 \\
\hline 2004 & 55.9 & 18.2 & 278 & 9.8 & 3.5 \\
\hline 2005 & 55.1 & 18.0 & 271 & 11.9 & 4.1 \\
\hline 2006 & 53.6 & 18.2 & 267 & 12.5 & 4.5 \\
\hline 2007 & 54.6 & 17.9 & 270 & 11.9 & 4.0 \\
\hline 2008 & 53.3 & 19.8 & 257 & $11.5^{3}$ & 4.3 \\
\hline 2009 & 53.7 & 19.9 & 266 & $10.4^{3}$ & 4.6 \\
\hline 2010 & 54.1 & 20.1 & 262 & $9.2^{3}$ & 4.2 \\
\hline 2011 & 54.9 & 20.6 & 259 & $10.2^{3}$ & 4.1 \\
\hline 2012 & 56.1 & 20.7 & 255 & $10.2^{3}$ & 3.9 \\
\hline 2013 & 57.0 & 20.8 & 250 & $9.7^{3}$ & 3.7 \\
\hline 2014 & 57.0 & 21.2 & 251 & $9.9^{3}$ & 3.8 \\
\hline 2015 & 57.3 & 20.9 & 250 & 9.8 & 3.8 \\
\hline 2016 & 56.3 & 20.9 & 287 & 10.0 & 3.7 \\
\hline 2017 & 55.7 & 21.1 & 289 & 9.3 & 3.5 \\
\hline 2018 & 55.2 & 20.8 & 292 & 10.4 & 4.0 \\
\hline 2019 & 54.6 & 21.6 & 301 & $\ldots$ & $\ldots$ \\
\hline
\end{tabular}

Data of the Centre for Disease Prevention and Control. Calculated on the basis of the results of 2011 Census.

2 Data of the Centre for Disease Prevention and Control and the Central Statistical Bureau used in calculation.

3 Data updated. 


\section{Table 10. Education indications}

\begin{tabular}{|c|c|c|c|c|c|c|c|c|}
\hline & 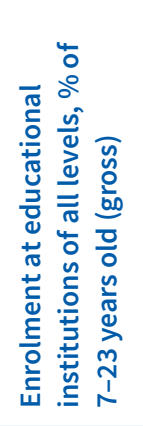 & 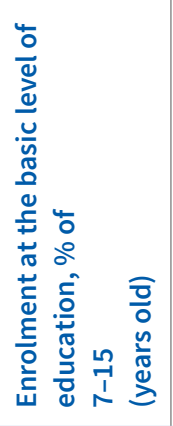 & 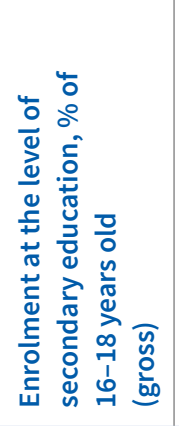 & 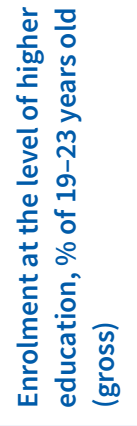 & 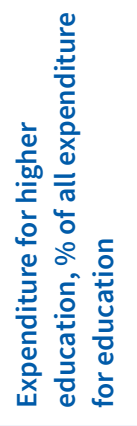 & 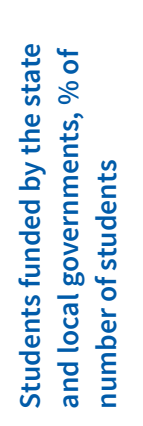 & 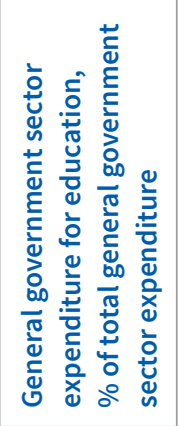 & 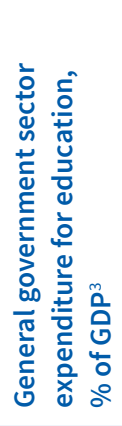 \\
\hline 2000 & 86.3 & 92.5 & 102.3 & 62.4 & 22.7 & 33.7 & 14.6 & 5.4 \\
\hline 2001 & 88.2 & 95.0 & 98.5 & 68.3 & 23.4 & 29.9 & 16.0 & 5.5 \\
\hline 2002 & 89.6 & 96.0 & 97.2 & 73.0 & 24.1 & 27.1 & 16.1 & 5.7 \\
\hline 2003 & 90.9 & 95.9 & 100.9 & 76.2 & 24.6 & 24.2 & 15.8 & 5.3 \\
\hline 2004 & 91.6 & 97.1 & 102.1 & 76.4 & 25.5 & 23.5 & 17.0 & 5.9 \\
\hline 2005 & 91.1 & 97.8 & 101.4 & 75.7 & 27.6 & 22.8 & $15.5^{2}$ & 5.3 \\
\hline 2006 & 90.0 & 98.0 & 100.4 & 73.7 & 27.2 & 23.3 & $15.4^{2}$ & 5.5 \\
\hline 2007 & 89.3 & 99.2 & 99.7 & 72.1 & 26.7 & 25.0 & 16.3 & 5.6 \\
\hline 2008 & 89.2 & 99.3 & 102.2 & 71.0 & 25.5 & 26.6 & 16.8 & 6.3 \\
\hline 2009 & 88.1 & 101.1 & 104.7 & 65.6 & 21.1 & 30.4 & $15.2^{2}$ & 6.7 \\
\hline 2010 & 88.5 & 102.4 & $106.1^{1}$ & 63.7 & 25.1 & 34.1 & $13.7^{2}$ & 6.2 \\
\hline 2011 & 89.0 & 102.2 & $108.5^{1}$ & 63.5 & $28.1^{2}$ & 35.9 & $14.5^{2}$ & 5.9 \\
\hline 2012 & $90.3^{1}$ & $102.9^{1}$ & $110.2^{1}$ & $64.9^{1}$ & $27.1^{2}$ & 36.9 & $15.1^{2}$ & 5.7 \\
\hline 2013 & 91.4 & 102.5 & 113.4 & 65.6 & $25.6^{2}$ & 38.5 & $15.2^{2}$ & 5.7 \\
\hline 2014 & 93.4 & 103.0 & 115.2 & 67.9 & $25.1^{2}$ & 40.4 & $15.4^{2}$ & 5.9 \\
\hline 2015 & 96.2 & 102.7 & 118.1 & 72.9 & 26.4 & 41.4 & 15.4 & 5.9 \\
\hline 2016 & 98.9 & 101.4 & 120.8 & 79.3 & 21.7 & 41.6 & 14.7 & 5.5 \\
\hline 2017 & 100.8 & 100.9 & 117.8 & 86.7 & 22.5 & 41.7 & 15.3 & 5.8 \\
\hline 2018 & 101.5 & 100.5 & 114.9 & 91.6 & $\ldots$ & 41.3 & 15.1 & 5.8 \\
\hline 2019 & 101.7 & 100.8 & 111.5 & 93.7 & $\ldots$ & 41.3 & $\ldots$ & $\ldots$ \\
\hline
\end{tabular}

1 Data recalculated in accordance with the results of 2011 Census.

2 Data updated.

3 Data from Eurostat webpage:

http://appsso.eurostat.ec.europa.eu Tabula [gov_10a_exp]. 


\section{Table 11. Human intellectual potential}

\begin{tabular}{|c|c|c|c|c|c|}
\hline & 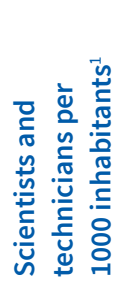 & 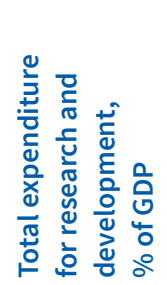 & 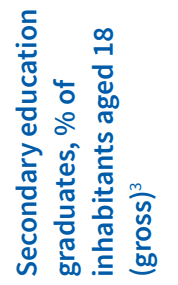 & 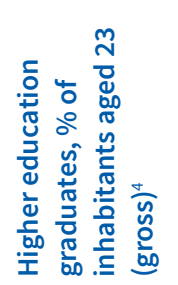 & 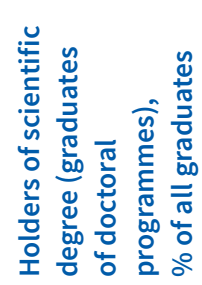 \\
\hline 2000 & 2.3 & 0.45 & 87.5 & 63.0 & 0.3 \\
\hline 2001 & 2.3 & 0.41 & 85.6 & 59.8 & 0.2 \\
\hline 2002 & 2.3 & 0.42 & 72.4 & 66.9 & 0.3 \\
\hline 2003 & 2.1 & 0.38 & 69.3 & 76.3 & 0.3 \\
\hline 2004 & 2.9 & 0.42 & 75.9 & 82.2 & 0.4 \\
\hline 2005 & 2.4 & 0.56 & 79.4 & $81.7^{1}$ & 0.4 \\
\hline 2006 & 2.8 & 0.70 & 78.6 & $80.2^{1}$ & 0.4 \\
\hline 2007 & 2.8 & 0.59 & 78.3 & $77.1^{1}$ & 0.5 \\
\hline 2008 & 2.5 & 0.61 & 81.7 & $70.0^{1}$ & 0.6 \\
\hline 2009 & 2.5 & 0.46 & 81.3 & $77.4^{1}$ & 0.7 \\
\hline 2010 & 2.7 & 0.60 & 87.6 & $79.9^{1}$ & 0.5 \\
\hline 2011 & 2.7 & 0.70 & 92.1 & 77.6 & 1.2 \\
\hline 2012 & $3.2^{2}$ & 0.66 & 104.4 & 69.6 & 1.2 \\
\hline 2013 & 3.8 & 0.60 & 98.7 & 73.7 & 1.2 \\
\hline 2014 & 4.1 & 0.69 & 105.5 & 60.6 & 1.5 \\
\hline 2015 & 4.0 & 0.62 & 106.8 & 63.5 & 1.2 \\
\hline 2016 & 5.6 & 0.44 & 93.9 & 61.9 & 1.0 \\
\hline 2017 & 5.7 & 0.51 & 118.8 & 66.9 & 1.0 \\
\hline 2018 & 6.3 & 0.63 & 113.5 & 77.6 & 0.8 \\
\hline 2019 & $\ldots$ & $\ldots$ & $\ldots$ & 81.7 & 0.9 \\
\hline
\end{tabular}

Data recalculated in accordance with the results of 2011 Census.

2 In accordance with Eurostat methodology, since 2012, science support personnel is also included.

3 Calculated from the total number of secondary education (general and vocational) graduates in the respective year.

4 Calculated from the total number of higher education graduates in the respective year. 


\section{Table 12. Employment}

\begin{tabular}{|c|c|c|c|c|c|c|}
\hline & \multirow{2}{*}{ 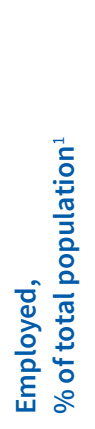 } & \multicolumn{3}{|c|}{ 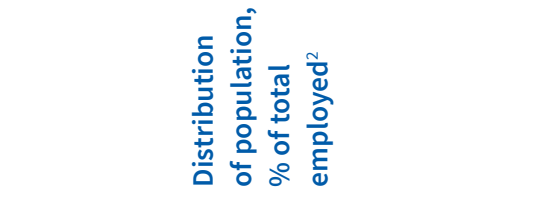 } & \multirow{2}{*}{ 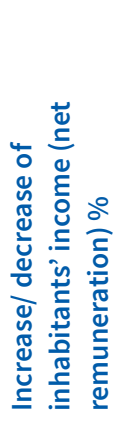 } & \multirow{2}{*}{ 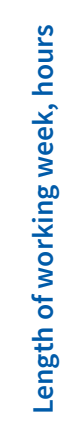 } \\
\hline & & 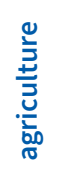 & 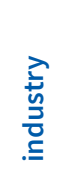 & 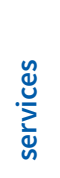 & & \\
\hline 2000 & 51.4 & 15 & 26 & 59 & 5.7 & 41.4 \\
\hline 2001 & 52.2 & 15 & 26 & 59 & 6.1 & 41.3 \\
\hline 2002 & 53.9 & 15 & 26 & 59 & 8.0 & $41.9^{3}$ \\
\hline 2003 & 54.5 & 14 & 27 & 59 & 10.9 & 41.7 \\
\hline 2004 & 54.9 & 13 & 27 & 60 & 8.8 & $40.9^{3}$ \\
\hline 2005 & 55.9 & 12 & 26 & 62 & 17.0 & 41.3 \\
\hline 2006 & 59.7 & 11 & 28 & 61 & 23.1 & 41.3 \\
\hline 2007 & 61.6 & 10 & 28 & 62 & 32.0 & $40.6^{3}$ \\
\hline 2008 & 62.0 & 8 & 29 & 63 & 22.5 & 39.4 \\
\hline 2009 & 54.3 & 9 & 24 & 67 & -2.3 & 38.9 \\
\hline 2010 & 52.0 & 9 & $23^{3}$ & $68^{3}$ & -7.5 & 38.4 \\
\hline 2011 & 54.0 & 9 & 23 & 68 & 4.5 & 38.5 \\
\hline 2012 & 56.1 & 8 & 24 & 68 & 3.9 & 38.3 \\
\hline 2013 & 58.2 & 8 & 24 & 68 & 5.6 & 38.3 \\
\hline 2014 & 59.1 & 8 & 24 & 68 & 8.6 & 38.6 \\
\hline 2015 & 60.8 & 8 & 24 & 68 & 7.6 & 38.3 \\
\hline 2016 & 61.6 & 8 & 24 & 68 & 4.7 & 38.4 \\
\hline 2017 & 62.9 & 7 & 23 & 70 & 7.0 & 38.3 \\
\hline 2018 & 64.5 & 7 & 24 & 69 & 9.9 & 38.3 \\
\hline 2019 & 65.0 & 7 & 24 & 69 & 6.8 & 37.9 \\
\hline
\end{tabular}

Data of Labour Force Survey. In 2000-2001, persons 15 years old and older, since 2002 - 15-74 years old.

2 Since 2008 - Statistical classification of economic activities (NACE, Rev. 2)

3 Data recalculated in accordance with the results of 2011 Census. 


\section{Table 13. Unemployment indicators (end of year)}

\begin{tabular}{|c|c|c|c|c|c|c|}
\hline & \multirow{2}{*}{ 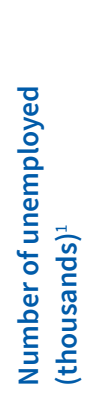 } & \multicolumn{2}{|c|}{ 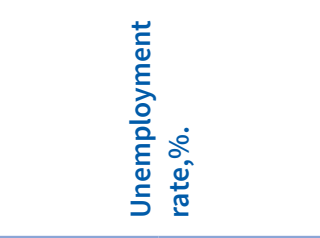 } & \multirow{2}{*}{ 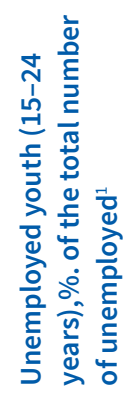 } & \multirow{2}{*}{ 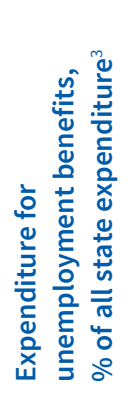 } & \multirow{2}{*}{ 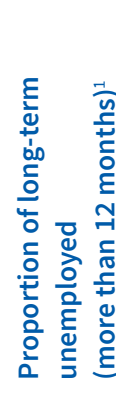 } \\
\hline & & $\begin{array}{l}\frac{1}{\pi} \\
\stackrel{0}{0} \\
+0\end{array}$ & 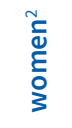 & & & \\
\hline 2000 & 93.3 & 7.8 & 9.2 & 14.8 & 1.2 & 29.0 \\
\hline 2001 & 91.6 & 7.7 & 9.0 & 14.6 & 1.0 & 26.6 \\
\hline 2002 & 89.7 & 8.5 & 10.5 & 13.9 & 1.1 & 26.4 \\
\hline 2003 & 90.6 & 8.6 & 10.5 & 13.2 & 1.1 & 26.1 \\
\hline 2004 & 90.8 & 8.5 & 9.6 & 12.8 & 1.0 & 25.6 \\
\hline 2005 & 78.5 & 7.4 & 8.8 & 14.0 & 1.2 & 26.2 \\
\hline 2006 & 68.9 & 6.5 & 8.3 & 14.0 & 1.1 & 23.1 \\
\hline 2007 & 52.3 & 4.9 & 6.3 & 12.9 & 0.9 & 18.0 \\
\hline 2008 & 76.4 & 7.0 & 7.6 & 13.6 & 0.9 & 11.1 \\
\hline 2009 & 179.2 & 16.0 & 16.8 & 14.5 & 2.5 & 13.5 \\
\hline 2010 & 162.5 & 14.3 & 15.9 & 14.3 & 2.1 & 37.8 \\
\hline 2011 & 130.3 & 11.5 & 13.4 & 11.8 & 1.3 & 43.7 \\
\hline 2012 & 104.1 & 10.5 & 12.0 & 10.1 & 0.9 & 44.2 \\
\hline 2013 & 93.3 & 9.5 & 10.6 & 9.5 & 1.1 & 35.4 \\
\hline 2014 & 82.0 & 8.5 & 19.4 & 9.2 & 1.1 & 33.0 \\
\hline 2015 & 81.8 & 8.7 & 9.4 & 8.4 & 1.3 & 29.7 \\
\hline 2016 & 78.4 & 8.4 & 9.1 & 9.7 & 1.4 & 28.7 \\
\hline 2017 & 61.5 & 6.8 & 5.5 & 6.7 & 1.3 & 28.7 \\
\hline 2018 & 59.6 & 6.4 & 6.8 & 5.8 & 1.2 & 25.1 \\
\hline 2019 & 57.8 & 6.2 & 6.4 & 5.8 & $\ldots$ & 21.0 \\
\hline
\end{tabular}

1 Data updated. Data of the State Employment Agency (SEA).

2 Calculation of CSB, using the number of unemployed (women) registered with SEA. The unemployment rate among women is calculated as the proportion of economically active women.

3 Since 2007, the indicator is calculated in accordance with the Government's function "Support in case of unemployment", which comprises expenditure for unemployment benefits. 


\section{Table 14. Priorities in state expenditure}

\begin{tabular}{|c|c|c|c|}
\hline & $\begin{array}{c}\text { General government sector } \\
\text { expenditure for defence, } \\
\% \text { of GDP }\end{array}$ & $\begin{array}{c}\text { General government sector } \\
\text { expenditure for health, } \\
\% \text { of GDP }\end{array}$ & $\begin{array}{l}\text { General government sector } \\
\text { expenditure for education, } \\
\qquad \% \text { of GDP }{ }^{1}\end{array}$ \\
\hline 2000 & 0.9 & 3.9 & 5.4 \\
\hline 2001 & 0.9 & 3.2 & 5.5 \\
\hline 2002 & 1.1 & 3.7 & 5.7 \\
\hline 2003 & 1.2 & 3.4 & 5.3 \\
\hline 2004 & 1.3 & 3.5 & 5.9 \\
\hline 2005 & 1.2 & 4.1 & 5.3 \\
\hline 2006 & 1.4 & 4.5 & 5.5 \\
\hline 2007 & 1.4 & 4.0 & 5.6 \\
\hline 2008 & 1.5 & 4.3 & 6.3 \\
\hline 2009 & 1.2 & 4.6 & 6.7 \\
\hline 2010 & 1.0 & 4.2 & 6.2 \\
\hline 2011 & 1.0 & 4.1 & 5.9 \\
\hline 2012 & 0.9 & 3.9 & 5.7 \\
\hline 2013 & 0.9 & 3.7 & 5.7 \\
\hline 2014 & 0.9 & 3.8 & 5.9 \\
\hline 2015 & 1.0 & 3.8 & 5.9 \\
\hline 2016 & 1.6 & 3.8 & 5.5 \\
\hline 2017 & 1.7 & 3.5 & 5.8 \\
\hline 2018 & 2.1 & 4.0 & 5.8 \\
\hline 2019 & $\ldots$ & $\ldots$ & $\ldots$ \\
\hline
\end{tabular}

1 Data from Eurostat webpage:

http://appsso.eurostat.ec.europa.eu Tabula [gov_10a_exp]. 


\section{Table 15. Natural Resources}

\begin{tabular}{|c|c|c|c|c|}
\hline & $\begin{array}{l}\text { Land area, thousands } \\
\text { of } \mathrm{km}^{2}\end{array}$ & $\begin{array}{l}\text { Population density, } \\
\text { people per } \mathrm{km}^{2} \\
\text { (end of the year) }\end{array}$ & $\begin{array}{l}\text { Agricultural land, } \\
\% \text { of the land } \text { area }^{1}\end{array}$ & $\begin{array}{c}\text { Forests, } \\
\% \text { of the land area }\end{array}$ \\
\hline 2000 & 64.6 & 37 & 38.5 & 44.4 \\
\hline 2001 & 64.6 & 36 & 38.4 & 44.3 \\
\hline 2002 & 64.6 & 36 & 38.3 & 44.5 \\
\hline 2003 & 64.6 & 36 & 38.3 & 44.7 \\
\hline 2004 & 64.6 & 36 & 38.2 & 45.0 \\
\hline 2005 & 64.6 & 36 & 38.1 & 45.2 \\
\hline 2006 & 64.6 & 35 & 38.0 & 45.4 \\
\hline 2007 & 64.6 & 35 & 37.9 & 45.5 \\
\hline 2008 & 64.6 & 35 & 37.7 & 45.7 \\
\hline 2009 & 64.6 & 35 & 37.6 & 45.8 \\
\hline 2010 & 64.6 & 33 & 37.6 & 45.9 \\
\hline 2011 & 64.6 & 32 & 37.3 & 46.3 \\
\hline 2012 & 64.6 & 32 & 37.1 & 46.5 \\
\hline 2013 & 64.6 & 31 & 36.9 & 46.7 \\
\hline 2014 & 64.6 & 31 & 36.7 & 47.0 \\
\hline 2015 & 64.6 & 31 & 36.5 & 47.2 \\
\hline 2016 & 64.6 & 30 & 36.2 & 47.6 \\
\hline 2017 & 64.6 & 30 & 36.0 & 47.8 \\
\hline 2018 & 64.6 & 30 & 36.0 & 47.7 \\
\hline 2019 & 64.6 & 30 & 36 & 47.7 \\
\hline
\end{tabular}

1 Data of the State Land Service. 


\section{Table 16. National income indicators}

\begin{tabular}{|c|c|c|c|c|c|c|c|c|c|c|}
\hline & 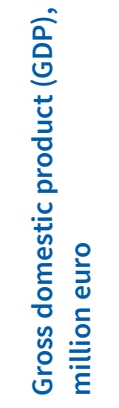 & 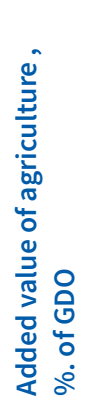 & 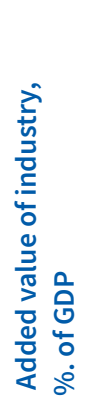 & 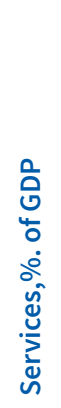 & 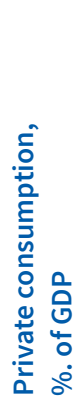 & 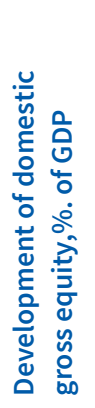 & 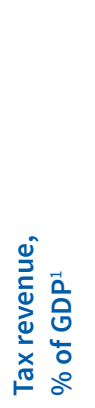 & 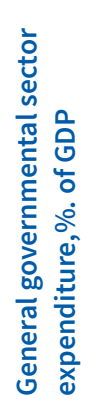 & 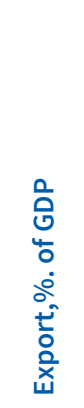 & 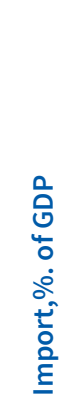 \\
\hline 2000 & 6850.3 & 5 & 20 & 75 & 62.3 & 25.2 & 11.0 & 37.3 & 36.9 & 44.9 \\
\hline 2001 & 7460.1 & 5 & 19 & 76 & 61.4 & 27.4 & 10.4 & 34.8 & 38.1 & 48.5 \\
\hline 2002 & 8397.1 & 5 & 19 & 76 & 61.2 & 24.6 & 10.1 & 35.1 & 36.6 & $46.7^{1}$ \\
\hline 2003 & 9552.7 & 5 & 18 & 77 & 61.0 & 24.8 & 10.7 & 33.5 & 36.2 & 48.7 \\
\hline 2004 & 11048.7 & 5 & 18 & 77 & 61.4 & 28.9 & 10.8 & 34.7 & 39.1 & $54.6^{1}$ \\
\hline 2005 & 13597.2 & 4 & 16 & 80 & 60.1 & 31.3 & 11.6 & 34.3 & 43.2 & 57.7 \\
\hline 2006 & 17101.9 & 4 & 15 & 81 & 62.9 & 34.2 & 12.0 & 36.0 & 40.0 & $60.6^{1}$ \\
\hline 2007 & 22592.0 & 4 & 15 & 81 & 58.8 & 36.5 & 11.4 & 34.0 & 38.5 & $57.5^{1}$ \\
\hline 2008 & 24351.2 & 3 & 14 & 83 & 56.9 & 32.1 & 10.3 & 37.6 & $39.5^{1}$ & 52.5 \\
\hline 2009 & 18826.6 & 4 & 16 & 80 & 59.4 & 22.6 & 10.5 & 44.2 & 42.6 & $44.2^{1}$ \\
\hline 2010 & 17937.9 & 4 & 19 & 77 & 62.6 & 19.4 & 11.3 & 45.5 & 53.7 & $55.1^{1}$ \\
\hline 2011 & 20302.8 & 4 & 18 & 78 & 60.5 & 22.2 & 11.2 & 40.5 & $57.8^{1}$ & $62.8^{1}$ \\
\hline 2012 & 21885.6 & 4 & 18 & 69 & 59.7 & 25.5 & 11.6 & 38.0 & $61.3^{1}$ & $65.8^{1}$ \\
\hline 2013 & 22831.5 & 4 & 17 & 79 & 60.5 & 23.2 & 12.0 & 37.7 & $60.3^{1}$ & $63.9^{1}$ \\
\hline 2014 & 23681.5 & $3^{1}$ & $20^{1}$ & $77^{1}$ & 60.0 & 22.6 & 12.2 & 38.2 & $60.7^{1}$ & $62.2^{1}$ \\
\hline 2015 & 24353.1 & 4 & $20^{1}$ & $76^{1}$ & 59.2 & 22.1 & 12.5 & 38.4 & $60.4^{1}$ & $60.9^{1}$ \\
\hline 2016 & 24925.6 & 3 & 19 & 78 & 60.3 & 18.2 & 13.1 & 37.3 & 60.0 & 59.1 \\
\hline 2017 & 26856.6 & 4 & 22 & 74 & 60.7 & 19.9 & 12.9 & 37.9 & 60.5 & 61.8 \\
\hline 2018 & 29056.1 & 4 & 22 & 74 & 58.0 & 22.9 & 13.4 & 36.8 & 61.5 & 59.9 \\
\hline 2019 & 30476.1 & 4 & 22 & 74 & 58.6 & 22.0 & 13.2 & $\ldots$ & 61.7 & 59.8 \\
\hline
\end{tabular}

GDP data calculated in accordance with the methodology of the European System of Accounts (ESA-2010).

1 Data updated. 


\section{Table $17 . \quad$ Economic development trends}

\begin{tabular}{|c|c|c|c|c|}
\hline & $\begin{array}{l}\text { GDP growth/ } \\
\text { decrease compared to } \\
\text { the previous year } \\
\text { (in comparable prices } \\
\text { of 2015),\%. }\end{array}$ & $\begin{array}{l}\text { Per capita GDP growth/ } \\
\text { decrease compared to } \\
\text { the previous year } \\
\text { (in comparable prices } \\
\text { of 2015), }\end{array}$ & $\begin{array}{l}\text { Annual inflation, } \\
\% \text { compared to } \\
\text { the previous year }{ }^{1}\end{array}$ & $\begin{array}{l}\text { Budget surplus or } \\
\text { deficit ,\% of GDP } \\
\text { (in actual prices) }\end{array}$ \\
\hline 2000 & 5.6 & 6.6 & 102.6 & -2.7 \\
\hline 2001 & 6.3 & 7.7 & 102.5 & -1.9 \\
\hline 2002 & 7.1 & 8.4 & 101.9 & -2.3 \\
\hline 2003 & 8.4 & 9.5 & 102.9 & -1.5 \\
\hline 2004 & 8.3 & 9.5 & 106.2 & -0.9 \\
\hline 2005 & 10.7 & 11.9 & 106.7 & -0.4 \\
\hline 2006 & 11.9 & 12.9 & 106.5 & -0.5 \\
\hline 2007 & 10.0 & 10.9 & 110.1 & -0.5 \\
\hline 2008 & -3.3 & -2.3 & 115.4 & -4.8 \\
\hline 2009 & -14.2 & -12.8 & 103.5 & -9.1 \\
\hline 2010 & -4.5 & -2.4 & 98.9 & -8.7 \\
\hline 2011 & 6.3 & 8.3 & 104.4 & -4.3 \\
\hline 2012 & 4.1 & 5.4 & 102.3 & -1.2 \\
\hline 2013 & 2.3 & 3.4 & 100.0 & -1.2 \\
\hline 2014 & 1.9 & 2.9 & 100.6 & -1.5 \\
\hline 2015 & 3.3 & 4.1 & 100.2 & -1.4 \\
\hline 2016 & 1.8 & 2.7 & 102.2 & 0.1 \\
\hline 2017 & 3.8 & 4.8 & 102.9 & -0.8 \\
\hline 2018 & 4.3 & 5.1 & 102.5 & -0.8 \\
\hline 2019 & 2.2 & 2.9 & 102.8 & -0.2 \\
\hline
\end{tabular}

1 Since 1 January 2016, to calculate the index of consumption prices, the harmonised index of consumer process, and harmonised indices of consumer prices at constant taxes, the European Classification of Individual Consumption according to Purpose (hereafter - ECOICOP) is used. 


\begin{tabular}{|c|c|c|c|c|c|c|}
\hline & 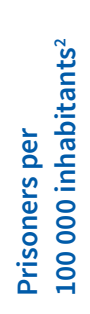 & 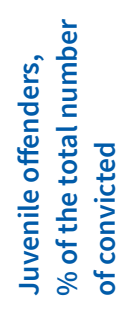 & 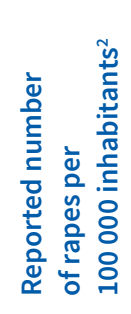 & 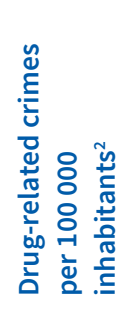 & 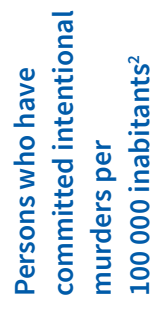 & 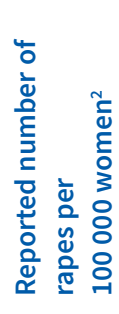 \\
\hline 2000 & 370.8 & 14.2 & 5.6 & 27.5 & 9.2 & 10.4 \\
\hline 2001 & 368.5 & 13.8 & 5.1 & 35.3 & 9.1 & 9.5 \\
\hline 2002 & 360.1 & 14.2 & 4.6 & 27.1 & 8.9 & 8.4 \\
\hline 2003 & 357.6 & 13.5 & 5.3 & 43.4 & 9.6 & 9.9 \\
\hline 2004 & 336.7 & 13.5 & $14.0^{3}$ & 50.4 & 8.7 & $25.9^{3}$ \\
\hline 2005 & 311.1 & 12.5 & $10.8^{4}$ & 46.6 & 5.6 & $19.9^{4}$ \\
\hline 2006 & 297.9 & 13.5 & 5.5 & 44.8 & 6.6 & 10.2 \\
\hline 2007 & 296.4 & 11.9 & 4.2 & 64.9 & 5.3 & 7.8 \\
\hline 2008 & 313.6 & 10.4 & 4.6 & 114.6 & 5.4 & 8.4 \\
\hline 2009 & 326.2 & 8.6 & 3.2 & 106.7 & 5.0 & 5.9 \\
\hline 2010 & 319.7 & 7.8 & 3.7 & 103.2 & 3.9 & 6.9 \\
\hline 2011 & 316.3 & 7.1 & 2.4 & 94.8 & 4.4 & 4.4 \\
\hline 2012 & 299.1 & 6.7 & 3.4 & 134.5 & 5.6 & 6.2 \\
\hline 2013 & 254.6 & 7.0 & 3.6 & 80.9 & 3.7 & 6.7 \\
\hline 2014 & 237.1 & 5.8 & 3.7 & 138.1 & 4.2 & 6.9 \\
\hline 2015 & 222.0 & 4.3 & 3.0 & 177.7 & 4.4 & 5.6 \\
\hline 2016 & 215.5 & 4.3 & 3.0 & 60.7 & 3.4 & 5.5 \\
\hline 2017 & 193.1 & 4.3 & 3.3 & 129.4 & 3.7 & 6.2 \\
\hline 2018 & 182.1 & 3.8 & 3.7 & 186.4 & 4.0 & 6.8 \\
\hline 2019 & 177.8 & $\ldots$ & 4.4 & 164.5 & 3.9 & 8.2 \\
\hline
\end{tabular}

1 On 1 October 2005, the Criminal Procedure Law entered into force. Pursuant to this law, a new system for registering criminal offences was introduced, therefore the data are not comparable to the previous years.

2 Data recalculated in accordance with the results of 2011 Census.

3 Pursuant to Para 11.2 of Part II of the Cabinet Regulation of 20 May 2003 No. 264 "Regulations for the Registering of Criminal Offences, in 2004, in one criminal case relating to a rape, additional episodes of the criminal offence are registered separately, hence the number of registered criminal offences in the period has increased significantly and the data on the number of reported criminal offences are not comparable to the previous period.

4 On 1 October 2005, the Criminal Procedure Law entered into force. Pursuant to this law, a new system for registering criminal offences was introduced, therefore the data are not comparable to the previous years. 


\section{Table 19. Prosperity, poverty and social expenditure}

\begin{tabular}{|c|c|c|c|c|c|c|}
\hline & 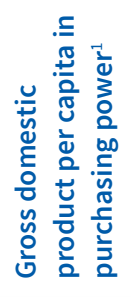 & 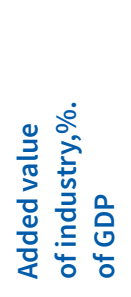 & 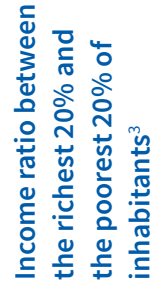 & 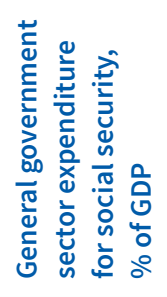 & 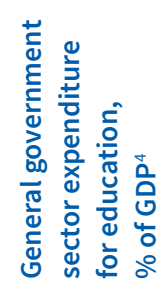 & 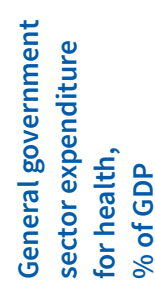 \\
\hline 2000 & $\ldots$ & 20 & 5.5 & 13.1 & 5.4 & 3.9 \\
\hline 2001 & $\ldots$ & 19 & $\ldots$ & 11.9 & 5.5 & 3.2 \\
\hline 2002 & $\ldots$ & 19 & $\ldots$ & 11.4 & 5.7 & 3.7 \\
\hline 2003 & $\ldots$ & 18 & $\ldots$ & 10.8 & 5.3 & 3.4 \\
\hline 2004 & 5,200 & 18 & 6.7 & 10.4 & 5.9 & 3.5 \\
\hline 2005 & 6,100 & 16 & 7.8 & 9.3 & 5.3 & 4.1 \\
\hline 2006 & 7,800 & 15 & 6.4 & 8.9 & 5.5 & 4.5 \\
\hline 2007 & 10,300 & 15 & 7.3 & 8.0 & 5.6 & 4.0 \\
\hline 2008 & 11,200 & 14 & 7.4 & 9.1 & 6.3 & 4.3 \\
\hline 2009 & 8,700 & 16 & 6.8 & 14.0 & 6.7 & 4.6 \\
\hline 2010 & 8,500 & 19 & 6.5 & 14.2 & 6.2 & 4.2 \\
\hline 2011 & 9,800 & 18 & 6.5 & 12.3 & 5.9 & 4.1 \\
\hline 2012 & 10,800 & 18 & 6.3 & 11.4 & 5.7 & 3.9 \\
\hline 2013 & 11,300 & 17 & 6.5 & 11.5 & 5.7 & 3.7 \\
\hline 2014 & 10,870 & $20^{2}$ & 6.5 & 11.4 & 5.9 & 3.8 \\
\hline 2015 & 12,350 & $20^{2}$ & 6.2 & 11.9 & 5.9 & 3.8 \\
\hline 2016 & 12,800 & 19 & 6.3 & 12.0 & 5.5 & 3.8 \\
\hline 2017 & 13,810 & 22 & 6.8 & 11.8 & 5.8 & 3.5 \\
\hline 2018 & 15,080 & 22 & 6.5 & 11.6 & 5.8 & 4.0 \\
\hline 2019 & 15,930 & 22 & $\ldots$ & $\ldots$ & $\ldots$ & $\ldots$ \\
\hline
\end{tabular}

1 Data from Eurostat webpage: http://epp.eurostat.ec.europa.eu/tgm/table.do?tab=table\&init=1\&language=en\&pcode=tec00001 \&plugin=1"plugin=1

2 Data updated.

3 Data recalculated in accordance with the results of 2011 Census.

4 Data from Eurostat webpage:

http://appsso.eurostat.ec.europa.eu Tabula [gov_10a_exp]. 


\section{Table 20. Communication}

\begin{tabular}{|c|c|c|c|c|c|}
\hline & 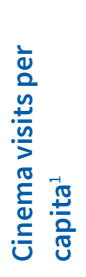 & 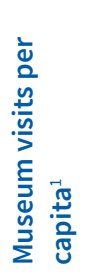 & 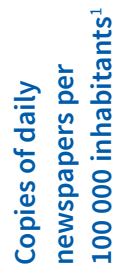 & 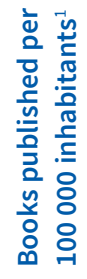 & 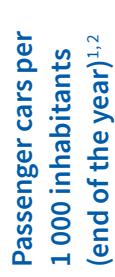 \\
\hline 2000 & 0.6 & 0.6 & 9.5 & 104.2 & 234 \\
\hline 2001 & 0.5 & 0.7 & 9.4 & 104.8 & 249 \\
\hline 2002 & 0.5 & 0.7 & 9.4 & 97.7 & 267 \\
\hline 2003 & 0.5 & 0.7 & 10.9 & 110.4 & 282 \\
\hline 2004 & 0.7 & 0.8 & 11.1 & 110.9 & 301 \\
\hline 2005 & 0.7 & 0.9 & 11.6 & 102.7 & 330 \\
\hline 2006 & 1.0 & 1.0 & 11.1 & 106.2 & 369 \\
\hline 2007 & 1.1 & 1.1 & 11.7 & 122.1 & 410 \\
\hline 2008 & 1.1 & 1.2 & 12.0 & 126.9 & 426 \\
\hline 2009 & 0.9 & 1.0 & 11.3 & 101.1 & 418 \\
\hline 2010 & 1.0 & 1.2 & 9.3 & 93.5 & $300^{2}$ \\
\hline 2011 & 1.0 & 1.2 & 10.0 & 100.0 & 295 \\
\hline 2012 & 1.1 & 1.3 & 12.3 & 99.3 & 302 \\
\hline 2013 & 1.2 & 1.3 & 12.0 & 107.0 & 314 \\
\hline 2014 & 1.2 & 1.5 & 12.7 & 106.0 & 329 \\
\hline 2015 & 1.2 & 1.6 & 12.7 & 107.3 & 345 \\
\hline 2016 & 1.3 & 1.8 & 13.5 & 111.2 & 341 \\
\hline 2017 & 1.3 & 1.9 & 9.4 & 111.0 & 356 \\
\hline 2018 & 1.3 & 2.0 & 9.4 & 111.7 & 369 \\
\hline 2019 & 1.4 & 1.9 & 8.0 & 109.4 & 381 \\
\hline
\end{tabular}

1 Data recalculated in accordance with the results of 2011 Census.

2 By the Cabinet Regulation of 30 December 2010 "Regulations on the Registration of Motor Vehicles", - exclusion of a motor vehicle from the register was envisaged. 


\section{Table 21. Urbanisation}

\begin{tabular}{|c|c|c|c|c|}
\hline & $\begin{array}{l}\text { Urban population, } \\
\% \text { of total population } \\
\text { (end of year) }\end{array}$ & $\begin{array}{c}\text { The annual rate } \\
\text { of increase "+" } \\
\text { or decrease "-" of urban } \\
\text { population }\end{array}$ & $\begin{array}{l}\text { Population of republican } \\
\text { cities } \% \text { of total urban } \\
\text { population (end of year) }{ }^{1}\end{array}$ & $\begin{array}{c}\text { Population in cities } \\
\text { with population above } \\
40 \text { thousand, } \% \text { of total } \\
\text { population (end of year) }\end{array}$ \\
\hline 2000 & $68.0^{1}$ & -0.9 & $76.0^{2}$ & 47.7 \\
\hline 2001 & 67.9 & -1.0 & 75.9 & 47.5 \\
\hline 2002 & 67.8 & -1.0 & 75.8 & 47.4 \\
\hline 2003 & 67.8 & -1.0 & 75.7 & 47.3 \\
\hline 2004 & 67.8 & -1.0 & 75.7 & 47.3 \\
\hline 2005 & 67.8 & -1.0 & 75.6 & 47.2 \\
\hline 2006 & 67.9 & -1.0 & 75.6 & 47.3 \\
\hline 2007 & 67.9 & -1.0 & 75.6 & 47.4 \\
\hline 2008 & 67.9 & -1.0 & 75.6 & 47.3 \\
\hline 2009 & 67.9 & -1.0 & 75.5 & 47.3 \\
\hline 2010 & 67.8 & -1.0 & 75.5 & $45.3^{3}$ \\
\hline 2011 & 67.8 & -1.0 & 75.5 & $45.3^{3}$ \\
\hline 2012 & 67.6 & -1.0 & $75.4^{2}$ & $45.2^{3}$ \\
\hline 2013 & 67.5 & -1.0 & $75.4^{2}$ & $45.2^{3}$ \\
\hline 2014 & 67.8 & -1.0 & $75.4^{2}$ & $45.5^{3}$ \\
\hline 2015 & 67.9 & -1.0 & $75.4^{2}$ & $45.6^{3}$ \\
\hline 2016 & 68.3 & -0.5 & 75.8 & $46.2^{3}$ \\
\hline 2017 & 68.5 & -0.6 & 75.8 & $46.3^{3}$ \\
\hline 2018 & 68.5 & -0.6 & 75.8 & 46.3 \\
\hline 2019 & 68.5 & -0.7 & 75.8 & 46.3 \\
\hline
\end{tabular}

1 Data recalculated in accordance with the results of 2011 Census.

2 Since Valmiera and Jēkabpils are republican cities, the number of inhabitants was recalculated.

3 The number of Ventspils' inhabitants has decreased and no longer is 40000. 


\section{Literature}

\section{Sources used in the Introduction}

Austers, A., Auers D., Šteinbuka, I. and Ozolina, Ž. (2019). 15 no 100. Latvijas dalības Eiropas Savienībā 15 gadi. Latvijas Intereses Eiropas savienībā, 2019, Nr. 1, 15-130. Retrieved from: https://www.mfa.gov.lv/images/Zurnals_Latvijas_ intereses_Eiropas_Savieniba_/ES_2019-1_WEB.pdf

Baltic Independent (1991). Finns 8.4 times richer than Estonians, survey says. Baltic Independent, No. 84, 8-14.

Birkavs, V. (2016). Pirmie izšķirošie gadi: Krievijas armijas izvešana un Latvijas nonākšana Eiropas Savienība priekštelpā. In: Atgriešanās Eiropā: Latvijas prezidentu, premjerministru, ministru un diplomātu esejas. Zinātne: Jelgava, 43.-84. Ipp.

Börzel, T. A. (2002). Pace-Setting, Foot-Dragging, and Fence-Sitting: Member State Responses to Europeanization. JCMS, 40(2), 193-214.

Bulmer, S. J., Lequesne, C. (eds.) (2005). The Member States of the European Union. Oxford: Oxford University Press.

Cowles, M. G., Caporaso, J., and Risse, T. (eds.) (2001). Transforming Europe: Europeanization and Domestic Change. Ithaca and London: Cornell University Press.

Dimitrova, A. L. (2002). Enlargement, Institution-Building and the EU's Administrative Capacity Requirement. Western European Politics, 25(4), 171-190.

Epstein, R. A. and Jacoby, W. (2014). Eastern Enlargement Ten Years On: Transcending the East-West Divide? JCMS, 52(1), $1-16$.

Featherstone, K. and Radaelli, C. (eds.) (2003). The Politics of Europeanization. Oxford: Oxford University Press.

Goetz, K. H. (2000). European Integration and National Executives: A Cause in Search of an Effect? West European Politics, 23 (4), 211-231.

Goetz, K. H. and Hix, S. (2001). Introduction: European Integration and National Political Systems. In: Goetz, K. H. and Hix, S. (eds.). Europeanised Politics? European Integration and National Political Systems. London: Frank Cass, pp. 1-26.

Graziano, P. and Vink, M. (eds.) (2007). Europeanization: New Research Agendas. Basingstoke: Palgrave Macmillan.

Grunhut, Z. (2017). Concepts, Approaches and Methods on Europeanization - A Meta-Analysis. Eastern Journal of European Studies, 8(1), 157-176.

Gwiazda, A. (2002). Europeanisation in Candidate Countries from Central and Eastern Europe. EPIC workshop, 19-22 September. Florence: European University Institute.

Kassim, H. and Menon, A. (2003). The Principal-Agent Approach and the Study of European Union: Promise Unfulfilled? Special Issue of Journal of European European Public Policy, 10(1), 121-139.

Kassim, H., Peters, B. G., and Wright, V. (eds.) (2000). The National Co-ordination of EU Policy: The Domestic Level. Oxford: Oxford University Press.

Ladrech, R. (1994). Europeanization of Domestic Policies and Institutions. Journal of Common Market Studies, 32(1), 69-88.

Ladrech, R. (2010). Europeanization and National Politics. Basingstoke: Palgrave Macmillan.

Laffan, B. (2003). Managing Europe from Home. Impact of the EU on Executive Government. A Comparative Analysis. OEUR Phase I. Occasional Paper 0.1.-08.03.

Lippert, B. and Umbach, G. (2005). The Pressure of Europeanisation. From post-Communist State Administration to Normal Players in the EU System. Baden-Baden: Nomos.

Matlak, M., Schimmelfennig, F. and Wozniakowski, T. P. (eds.) (2018). Europeanization Revisited: Central and Eastern Europe in the European Union. Florence: European University Institute.

Olsen, J. P. (2002). The Many Faces of Europeanization. JCMS, 40(5), 921-952.

Schimmelfennig, F. and Sedelmeier, U. (2002). Theorizing EU Enlargement: Research Focus, Hypotheses, and the State of Research. Journal of European Public Policy, 9, 500-528. 
Schimmelfennig, F. and Sedelmeier, U. (2005). Introduction: Conceptualising the Europeanization of Central and Eastern Europe. In: Schimmelfennig, F. and Sedelmeier, U. (eds). The Europeanization of Central and Eastern Europe. Cornell Studies in Political Economy. Ithaca: Cornell University Press, pp. 1-28.

Sedelmeier, U. (2011). Europeanisation in New Member and Candidate States. Living Reviews in European Governance, 6(1), 1-52. Retrieved from: http://europeangovernance-livingreviews.org/Articles/lreg-2011-1 (Accessed 12.10.2015).

\section{References for Part 1}

\subsection{Europeanization of Latvia's political system. Daunis Auers}

Attīstībai Par! (2018). Programma 13. Saeimas vēlēšanām. Retrieved from: https://sv2018.cvk.lv/pub/CandidateLists/Can didateList?id=9\%2BPedSGAgMQ3KDAMHFJsOQ\%3D\%3D

Auers, D. (2020). Latvia. In: Vit Hlousek and Petr Kaniok (eds.). The European Parliament Election of 2019 in East-Central Europe: Second order Euroscepticism. Cham, Switzerland: Palgrave Macmillan, pp. 131-150.

Dimitrova, A. (2002). Enlargement, Institution-Building and the EU's Administrative Capacity Requirement. West European Politics, 25(4), 171-190.

Dyson, K. and Goetz, K. H. (2003). Living with Europe: Germany and the Politics of Constraint. Oxford: Oxford University Press.

European Commission (2020). Public Opinion, Eurobarometer Interactive. Retrieved from: https://ec.europa.eu/ commfrontoffice/publicopinion/index.cfm/Chart/index

European Council Meeting Calendar (2020). Retrieved from: https://www.consilium.europa.eu/en/meetings/calendar/? Category=meeting\&Page $=1 \&$ dateFrom $=2019 \% 2 F 02 \% 2 F 01 \&$ dateTo $=2020 \% 2 F 08 \% 2 F 31 \&$ filters $=2031 \&$ filters $=2034$

European Parliament (2020). Funding from the European Parliament to political parties at European level per party and per year. Retrieved from: https://www.europarl.europa.eu/contracts-and-grants/files/political-parties-and-foundations/ european-political-parties/en-funding-amounts-parties-2020.pdf

Google Trends (2020). Arturs Krisjanis Karins and Egils Levits Compared from 1. September 2019 to 1. September 2020. Google Trends. Retrieved from: https://trends.google.com/trends/explore?q=\%2Fm\%2F02r61yz,\%2Fg\%2F121_5d8q

Ikstens, J. (2015). The Latvian Parliament and EU Affairs: A Passive Player with Strong Formal Powers. In: C. Hefftler, C. Neuhold, O. Rozenberg and J. Smith (eds.). The Palgrave Handbook of National Parliaments and the European Union. London: Palgreave Macmillan, pp. 548-562.

Kalninšs, V. (2019). The Use of Research-Based Evidence in the Latvian Parliament. The Case of Demography and Migration policies. Rīga: University of Latvia. Retrieved from: https://www.izm.gov.lv/images/zinatne/SMP_study.PDF

Latvia's State President (2020). Former Presidents of Latvia. Retrieved from: https://www.president.Iv/en/president-oflatvia/former-presidents-of-latvia\#gsc.tab=0

LSM (2017). Vienmēr prezidente: Vairas Vīkes-Freibergas paveiktais TOP 8 prezidentes amatā. Retrieved from: https://www. Ism.lv/vienmer-prezidente/raksts/top8-paveiktas

Maurer, A. and Wessels, W. (eds.). National Parliaments on their Ways to Europe: Losers or Latecomers? Baden-Baden: Nomos, 2001.

Nacionālā Apvienība (2018). Programma 13. Saeimas vēlēšanām. Retrieved from: https://sv2018.cvk.lv/pub/Candidate Lists/CandidateList?id=axC8x4iKXxa2gCU9m7iC2A\%3D\%3D

Pētersone, I. (2016). Jāmācās angḷu valoda, Kučinska kungs, iesaka Vīḳe-Freiberga. Latvijas Avīze, 17 February. Retrieved from: https://www.la.lv/jamacas-anglu-valoda-kucinska-kungs-iesaka-vike-freiberga

Poguntke, T., and Webb, P. (eds.) (2005). The Presidentialization of Politics: A Comparative Study of Modern Democracies. Oxford: Oxford University Press.

Ventspils (2017). Lembergs: vēstule par "Delnu" pārsūtīta Eiropas Komisijai. Retrieved from: https://www.youtube.com/ watch?v=NLEUtrSRg_8

Vilcāne, A. (2019). Komandējumiem plāno tērēt vairāk nekā 4.miljonus eiro. Dienas Bizness, 31 January. Retrieved from: http://www.db.lv/zinas/komandejumiem-plano-teret-vairak-neka-4-miljonus-eiro-483821.

Wilson, G. K. (1990). Interest Groups. Oxford: Basil Blackwell. 


\section{Interviews}

Lolita Čigāne, former chair of the Saeima's European Affairs Committee (2014-2018). 4 February 2019.

Liene Gatere, Director, Delna. 14 July 2020.

Andris Gobiņš. President of the European Movement in Latvia. 11 February 2019.

Edgars Ikstens. Board member, Vienotība. 22 May 2020.

Jelena Jesajana, Secretary General, Latvijas Attīstībai. 29 May 2020.

Zanda Kalniņa-Lukaševica, Parliamentary Secretary, Foreign Ministry. 26 February 2019.

Linda Ozola, Saeima deputy, Jaunā Konservatīvā Partija. 29 May 2020.

Aigars Rostovskis, President of the Latvian Chamber of Commerce. 10 July 2020.

Iveta Sers, International secretary, Saskaņa Social Democracy.1 June 2020.

Inese Stepina, Deputy Executive Director of the Latvian Employers Association (LDDK). 10 September 2020.

Vita Anda Tērauda, Chair of the Saeima's European Affairs Committee. 27 May 2020.

\subsection{Europeanization, soft instruments, and their consequences. Iveta Reinholde}

Borzel, T. (2005). Europeanization: How the European Union interacts with its member states. In: Bulmer, S. and Lequesne, C. The member states and the European Union. Oxford: Oxford University press.

Briede, J. (2000). Par samērīgumu administratīvajā procesā. Jurista Vārds, Nr. 16.

Cardona, F. (2009). Integrating National Administrations into the European Administrative Space. SIGMA Conference on Public Administration Reform and European Integration. Budva, Montenegro, 26-27 March.

CFLA (2019). Cesvainē notiks seminārs "Labā prakse ES fondu projektu īstenošanā". Retrieved from: https://www.cfla. gov.lv/lv/jaunumi/2019/cesvaine-notiks-seminars-laba-prakse-es-fondu-projektu-istenosana

Committee of the Regions (2005). Procedures for local and regional authority participation in European Policy Making in the member states. CoR Studies E-1/2005. Brussels, January 2005.

Diena (2013). Privātmāju īpašnieki nesteidz pieslēgties maǵistrālajiem ūdensvadiem. Retrieved from: https://www.diena. Iv/raksts/latvija/zinas/privatmaju-ipasnieki-nesteidz-pieslegties-magistralajiem-udensvadiem-14007376

Eiropas Komisija (2001). A White Paper “European Governance”. Brussels, 25.07.2001., COM (2001), 428 final.

Finanšu ministrija (2017). Informatīvais ziṇojums "Par atlīdzības sistēmu valsts pārvaldē”. Rīga.

Fridrihsone, M. (2010). Saldākās nozares rūgtais gals. Retrieved from: http://providus.lv/article/saldakas-nozares-rugtais-gals Hix, S. (2005). The Political System aof the European Union. Palgrave Macmillan.

Jaunatnes starptautisko programmu agentūra (n.d.). Par programmu "Jaunatne darbībā". Retrieved from: http:// jaunatne.gov.lv/lv/jaunatne-darbiba/jauniesu-un-jaunatnes-politikas-veidotaju-tiksanas/kas-ir-politikas-projekti

Knodt, M. (2004). International embeddedness of European multi-level governance. Journal of European Public Policy, 11, 4.

LNKC (2015). Rīgā notiks Eiropas Komisijas Atvērtās koordinācijas metodes darba grupas sanāksme. Retrieved from: https://www.Inkc.gov.lv/jaunumi/riga-notiks-eiropas-komisijas-atvertas-koordinacijas-metodes-darba-grupassanaksme/

LPS (2020). Starptautiskā sadarbība - Reǵionu komiteja. Retrieved from: https://www.lps.lv/lv/starptautiska-sadarbiba/ eiropas-regionu-komiteja/

Marks, G., Hooghes, L. (2001).Types of Multi-Level Governance. European Integration Online Papers. Vol. 5, No. 11.

Ministru kabinets (2009a). MK noteikumi Nr. 96 "Kārtība, kādā izstrādā, saskaṇo, apstiprina un aktualizē Latvijas Republikas nacionālās pozīcijas Eiropas Savienības jautājumos”, pieņemti 03.02.2009. Izgūts no: https://likumi.lv/ta/id/187419kartiba-kada-izstrada-saskano-apstiprina-un-aktualize-latvijas-republikas-nacionalas-pozicijas-eiropas-savienibas

Ministru kabinets (2009b). MK noteikumi Nr. 769. "Vecāko amatpersonu sanāksmes Eiropas Savienības jautājumos nolikums”, pieñemti 14.07.2009. Retrieved from: https://likumi.lv/ta/id/195056-vecako-amatpersonu-sanaksmeseiropas-savienibas-jautajumos-nolikums

Ministru kabinets (2019c). Konceptuālais zinojums "Par administratīvi teritoriālo iedalījumu". Apstiprināts ar Ministru kabineta 18.09.2019. rīkojumu Nr. 445. Retrieved from: http://www.varam.gov.lv/lat/administrativi_teritoriala_ reforma/?doc=27700 (skatīts 23.03.2020.) 
Nizzo, C. (1999). The European Administrative Space and the Role of the Court of Justice. SIGMA, Paris.

OECD (2018). OECD Regulatory Policy Outlook 2018. OECD Publishing, Paris. Retrieved from: https://doi.org/10.1787/ 9789264303072-en

Pabriks, A. (2005). Vienoti daudzveidībā. Diena, Nr. 18(4153).

SIGMA (1999). SIGMA Papers: No. 27 European principles for public administration. OECD, SIGMA.

SKDS (1999). Latvijas iedzīvotāju attieksme pret valsts pārvaldi un valsts civildienestu. Rīga, 1999. gada septembris.

SKDS (2001). Latvijas politiskās un ekonomiskās situācijas vērtējums sabiedrībā. Rīga, 2001. gada janvāris, 2001. gada aprīlis, 2001. gada augusts.

Toshkov, D. (n. d.) '55 years of EU Legislation'. Online presentation. Retrieved from: http://www.dimiter.eu/Eurlex.html

Valsts kanceleja (2018). Valsts pārvaldē nodarbināto skaits 2018. Retrieved from: https://mk.gov.lv/sites/default/files/ editor/Infografikas/valsts_parvalde_nodarbinato_skaits_2018.pdf

Valsts kanceleja (2019). Valsts pārvaldē nodarbināto skaits 2019. Retrieved from: https://mk.gov.lv/sites/default/files/ editor/Valsts_kanceleja/vk_cilvekresursi-2019.pdf

Vecāko amatpersonu sanāksme (2020). Protokols Nr. 6, 20.05.2020. Retrieved from: https://www.mfa.gov.lv/images/VAS/ VAS_protokols_20.05.2020.pdf

\subsection{Europeanization of Latvia's foreign policy. Toms Rostoks}

Aggestam, L., Bicchi, F. (2019). New Directions in EU Foreign Policy Governance: Cross-loading, Leadership and Informal Groupings. Journal of Common Market Studies, 57(3), 515-532.

Ministry of Foreign Affairs (2020a). Latvijas attīstības sadarbības politika. Retrieved from: https://www.mfa.gov.lv/ arpolitika/attistibassadarbiba/latvijas-attistibas-sadarbibas-politika

Ministry of Foreign Affairs (2020b). Konceptuālais ziṇojums "Par attīstības sadarbībai paredzētā finansējuma palielināšanu 2021.-2025. gadā".

Baun, M., Marek, D. (2013). The New Member States and the European Union: Foreign Policy and Europeanization. Routledge.

Brugée, I. (2017). Piesardzīgā tuvināšanās: Valda Zatlera oficiālā vizīte Maskavā 2010. gada decembrī. Latvijas ārlietu simtgade: darbi un personības. Sprūds, A., Ščerbinskis, V., Potjomkina, D. (ed.). Riga: Latvian Institute of International Affairs.

Christou, G., Kyris, G. (2017). The Impact of the Eurozone Crisis on National Foreign Policy: Enhancing Europeanization in the Case of Cyprus. Journal of Common Market Studies, 55(6), 1290-1305.

Council of the European Union (2003). European Security Strategy: A Secure Europe in a Better World.

Council of the European Union (2016). Outcome of the Council Meeting. Foreign Affairs. 3457th Council Meeting. Brussels, 14.03.2016.

Council of the European Union (2020). Council Decision (CFSP) 2020/1127 of 30 July 2020 amending Decision (CFSP) 2019/797concerning restrictive measures against cyber attacks threatening the Union or its Member States.

Eurobarometer 91 (2019). Standard Eurobarometer 91: Public Opinion in the European Union.

European Commission (2019). Special Eurobarometer 476: EU Citizens and Development Cooperation.

Hill, C., Wong, R. (2011). National and European Foreign Policies: towards Europeanization? Paper presented at the EUSA conference in Boston, USA, March 3-5.

Ignatāne, G. (2006). Latvija un attīstības sadarbība. Stratēgoiskās analīzes komisijas zinātniski pētnieciskie raksti, 4(10). Riga: Zinātne.

Jēgermanis, G. (2020). Allaž pret straumi ar draugu atbalstu Baltijas un Ziemel̦valstu koptelpā. Latvijas diplomātijas gadsimts. Drēgeris, M. (ed.) Riga: Zvaigzne ABC.

Latvijas intereses Eiropas Savienībā (2014/3). Riga: Latvian Association of Political Scientists.

Major, C. (2005). Europeanisation and Foreign and Security Policy - Undermining or Rescuing the Nation State? Politics, 25(3), 175-190.

McCarthy, C. (2019). EU Decision-Making after Brexit: QMV and the Balance of Power. Institute of International Affairs.

Michalski, A. (2013). Europeanization of National Forreign Policy: The Case of Denmark's and Sweden's Relations with China. Journal of Common Market Studies, 51(5), 884-900. 
Muižnieks, N. (ed.) (2006). Latvian-Russian Relations: Domestic and International Dimensions. Riga: University of Latvia Academic Press.

Muižnieks, N. (ed.) (2008). Manufacturing Enemy Images? Russian Media Portrayal of Latvia. Riga: University of Latvia Academic Press.

Muižnieks, N. (2011a). Latvian-Russian Relations: Dynamics since Latvia's Accession to the EU and NATO. Riga: University of Latvia Academic Press.

Muižnieks, N. (ed.) (2011b). The Geopolitics of History in Latvian-Russian Relations. Riga: University of Latvia Academic Press.

Olsen, J. P. (2002). The Many Faces of Europeanization. Journal of Common Market Studies, 40(5), 921-952.

Ozolina, Ž. (2005). Public Attitude towards EU Membership in Latvia. In: GLI Allargamenti Della CEE/UE 1961-2004. Landuyt, A., Pasquinucci, D. (eds.). Societa Editrice Il Mulino, pp. 507-532.

Ozolinga, Ž. (ed.) (2008a). Latvia-Russia-X. Riga: Zinātne.

Ozoliņa, Ž. (2008b). European Security and Defence Policy: The Latvian Perspective. In: New Security Issues in Northern Europe. Archer, C. (ed.). Abingdon: Routledge, 115-138.

Ozoliņa, Ž. (2012) Latvia. In: Life in Post-Communist Eastern Europe after EU Membership: Happy ever after? O’Beachain, D., Sheridan, V., Stan, S. (eds.). Abingdon: Routledge.

Ozoliņa, Ž., Šteinbuka, I. (ed.) (2019). Latvijas Eiropas cel̦š: $15<30<100$. Riga: University of Latvia Academic Press.

Ozoliņa, Ž., Tīsenkopfs, T. (red.) (2005). Latvija eiropeizācijas krustceḷos. Riga: University of Latvia Academic Press.

Pastore, G. (2015). EU Foreign Policy and the Uploading of National Preferences: The Case of Latvia. PhD dissertation.

Pelnēns, G. (ed.) (2009). The Humanitarian Dimension of Russian Foreign Policy toward Georgia, Moldova, Ukraine and the Baltic States. Riga: Centre for East European Policy Studies.

Pomorska, K. (2007). The Impact of Enlargement: Europeanization of Polish Foreign Policy? Tracking Adaptation and Change in the Polish Ministry of Foreign Affairs. The Hague Journal of Diplomacy, 2, 25-51.

Reire, G. (2020). Latvijas un Krievijas attiecību matrica. Latvijas diplomātijas gadsimts. Drēgeris, M. (ed.). Riga: Zvaigzne ABC. Riekstinš̌, M. (2020). Drošības un aizsardzības politika. Latvijas diplomātijas gadsimts. Drēgéeris, M. (ed.). Riga: Zvaigzne ABC. SKDS (2009). Attieksme pret attīstības sadarbību: Latvijas iedzīvotāju aptauja.

Smith, K. E. (2017). EU Member States at the UN: A Case of Europeanization Arrested? Journal of Common Market Studies, 55(3), 628-644.

Sorensen, C. (2019). Who is Big in Brussels? Think Tank Europa. Retrieved from: http://thinkeuropa.dk/sites/default/files/ paper_who_is_big_in_brussels.pdf

Sprūds, A. (ed.) (2012). The Economic Presence of Russia and Belarus in the Baltic States: Risks and Opportunities. Riga: Latvian Institute of International Affairs.

Sprūds, A., Rostoks, T. (eds.) (2009). Energy: Pulling the Baltic Sea Region Together or Apart? Riga: Zinātne.

Timofejevs-Henriksson, P. (2015). Europeanization of Foreign Aid Policy in Central and East Europe: The Role of EU, External Incentives and Identification in Foreign-Aid Policy Adoption in Latvia and Slovenia 1998-2010. Journal of European Integration, 37(4), 433-449.

Vanhoonacker, S., Pomorska, K. (2013). The European External Action Service and Agenda-Setting in European Foreign Policy. Journal of European Public Policy, 20(9), 1316-1331.

Vilson, M. (2015). The Foreign Policy of the Baltic States and the Ukrainian Crisis: A Case of Europeanization? New Perspectives, 23(2), 49-76.

\section{Interviews}

Maija Bilsēna, Ministry of Foreign Affairs, Personnel Department, Acting head of department, 11.08.2020.

Dina Giluce, Ministry of Defence, Defence Policy Department, Senior expert (EU issues), 21.07.2020.

Gints Jēgermanis, Ministry of Foreign Affairs, European Department, Director of department, 21.07.2020.

Ilgvars Kļava, Ministry of Foreign Affairs, Bilateral Relations Directorate, Ambassador-Director general, 30.07.2020.

Mārtinš̌ Līdaks, Ministry of Foreign Affairs, Personnel Registry Division, Head of division, 11.08.2020.

Mārtinš̌ Nilsons, Ministry of Defence, Defence Policy Department, Defence Counsellor for the PESCO, 21.07.2020. 
Kaspars Ozoliņš, Ministry of Foreign Affairs, Directorate of Security Policy and International Organizations, AmbassadorDirector general, 27.07.2020.

Reinis Trokša, Ministry of Foreign Affairs, Economic Relations and Development Policy Department, Director of department, 24.07.2020.

\subsection{Europeanization of the Latvian economy. Morten Hansen}

Bank of Latvia (2003, September 21). Press Release. Retrieved from: https://www.bank.lv/en/your-profile/media/ press-releases/6533-the-bank-of-latvias-comments-following-the-vote-in-the-september-20-2003-referendum-

Bank of Latvia (2011). Latvia and ERM II. Retrieved from: https://www.bank.lv/en/about-us/5834-on-latvias-participationin-the-exchange-rate-mechanism-ii

Bank of Latvia $(2013,1)$. International cooperation. Retrieved from: https://www.bank.lv/en/your-profile/media/pressreleases/550-publications/3182-international-cooperation

Bank of Latvia (2013, 2). On euro introduction. Retrieved from: https://www.bank.lv/en/statistics/information-for-datausers/561-monetary-policy/2655-iii-some-other-questions-related-to-the-repegging-of-the-lats

Bank of Latvia (1992). Law "On the Bank of Latvia”. Retrieved from: https://www.bank.lv/en/about-us/8436-law-on-thebank-of-latvia

Beetsma, R. and DeBrun, X. (2018). Independent fiscal councils and the conduct of fiscal policy. Insightes from a new eBook. Retrieved from: https://voxeu.org/article/independent-fiscal-councils-and-conduct-fiscal-policy-insights-new-ebook

Blanchard, O. J., Griffiths, M., Gruss, B. (2013). Boom, Bust, Recovery: Forensics of the Latvia Crisis. Brookings papers. Retrieved from: https://www.brookings.edu/wp-content/uploads/2016/07/2013b_blanchard_latvia_crisis.pdf

Calmfors, L., Wren-Lewis, S. (2011). What should fiscal councils do? Retrieved from: https://www.oecd.org/gov/budgeting/47741710.pdf

Council of the European Union (2011). EU Directive 2011/85. Retrieved from: https://eur-lex.europa.eu/legal-content/EN/ TXT/PDF/?uri=CELEX:32011L0085\&from=EN

Court of Justice (2019). Press release 18/19. Retrieved from: https://curia.europa.eu/jcms/upload/docs/application/ pdf/2019-02/cp190018en.pdf

de Grauwe, P. (2009). The politics of the Maastricht convergence criteria. Retrieved from: https://voxeu.org/article/ politics-maastricht-convergence-criteria

European Commission (1997). Agenda 2000. For a stronger and wider union. Bulletin of the European Union, Supplement $5 / 97$.

European Commission (2006). Press release. Commission assesses the state of convergence in Lithuania. Retrieved from: https://ec.europa.eu/commission/presscorner/detail/en/IP_06_622

European Commission (2012). Treaty on Stability, Coordination and Governance in the Economic and Monetary Union (Fiscal Compact). Retrieved from: https://eur-lex.europa.eu/legal-content/EN/TXT/?uri=legissum:1403_3

European Commission (2013). Convergence Report 2013 on Latvia. European Economy 3/2013. Retrieved from: https:// ec.europa.eu/economy_finance/publications/european_economy/2013/pdf/ee3_en.pdf

European Commission (2020) Excessive Deficits Procedures - Overview. Retrieved from: https://ec.europa.eu/info/businesseconomy-euro/economic-and-fiscal-policy-coordination/eu-economic-governance-monitoring-prevention-correction/ stability-and-growth-pact/corrective-arm-excessive-deficit-procedure/excessive-deficit-procedures-overview_en

European Commission. Treaty on the Functioning of the European Union (2012, October 26). Retrieved from: https://eurlex.europa.eu/eli/treaty/tfeu_2012/oj

Fiscal Discipline Council. Fiscal Discipline Law (2014, January 1). Retrieved from: https://fiscalcouncil.lv/files/uploaded/ E2316-FiscalDisciplineLaw.pdf

Jankovics, L. and Sherwood, M. (2017). Independent Fiscal Institutions in the EU Member States: The Early Years. Discussion Paper 067. Retrieved from: https://ec.europa.eu/info/sites/info/files/dp_067_en.pdf

Letter to Charles Michel (2020, March 25). Retrieved from: http://www.governo.it/sites/new.governo.it/files/letter_ michel_20200325_eng.pdf

Moodys (2020). Retrieved from: https://www.moodys.com/

Standard \& Poors (2020). Retrieved from: https://www.standardandpoors.com/en_EU/web/guest/home 


\subsection{The Satversme, the Constitutional Court and the European Union. Jānis Pleps}

Albi, A. (2005). EU Enlargement and the Constitutions of Central and Eastern Europe. Cambridge: Cambridge University Press.

Balodis, R. (2004). The Constitution of Latvia. Trier: Institut für Rechtspolitik an der Universität Trier.

Balodis, R. (2014). Satversmes ievads. In: Latvijas Republikas Satversmes komentāri. levads. I nodaḷa. Vispārējie noteikumi. Sagatavojis aut. kol. prof. R. Baloža zinātniskā vadībā. Rīga: Latvijas Vēstnesis, 91.-135. Ipp.

Besselink, L. F. M. (2010). National and constitutional identity before and after Lisbon. Utrecht Law Review, Vol. 6, No. 3, 36-49.

Buka, A. (2017). Eiropas Savienība un tās tiesības - no putna lidojuma. Jurista Vārds, 7, Nr. 46, 43.-44.

Claes, M., Reestman, J.-H. (2015). The Protection of National Constitutional Identity and the Limits of European Integration at the Ocassion of the Gauweiler Case. German Law Journal, Vol. 16, No. 4, 917-970.

CVK [CEC] (2003). Par tautas nobalsošanas par Latvijas dalību Eiropas Savienībā rezultātiem: Centrālās vēlēšanu komisijas 2003. gada 6. oktobra lēmums Nr. 20. Latvijas Vēstnesis, Nr. 138.

Darba grupa [Working group] (2001). Kādēl Latvijas konstitūcijā nepieciešami labojumi. Darba grupas Satversmes grozījumu izstrādei piedāvātā projekta teorētiskais pamatojums. Jurista Vārds, Nr. 207, 1.-3.

Dedman, M. J. (2010). The Origins and Development of the European Union. A History of European Integration. Second edition. New York: Routledge, 2010.

Endziņš, A., Jelāgins, J., Ušacka, A. (2000). Dissenting Opinions of the Constitutional Court justices in case No. 2000-03-01 "On Compliance of Article 5 (Items 5 and 6) of the Saeima Election Law and Article 9 (Items 5 and 6) of the City Dome, Region Dome and Rural Council Election Law with Articles 89 and 101 of the Satversme, Article 14 of the Convention for the Protection of Human Rights and Article 25 of the International Covenant on Civil and Political Rights". Retrieved from: https://www.satv.tiesa.gov.lv/web/viewer.html?file=/wp-content/uploads/2000/03/2000-03-01_Atseviskas_ domas_ENG.pdf

Endziñš, A. (2003). Latvijas un Eiropas Savienības tiesības un to savstarpējā hierarhija. Jurista Vārds, Nr. 43, 4.-6.

Endziņš, A. (2004). Eiropas Konstitūcijas līgums un Latvijas Republikas Satversme. Jurista Vārds, Nr. 39, 2.-5.

ECJ (1964). Judgment of the Court of 15 July 1964. 6/64 Flaminio Costa v E.N.E.L. Retrieved from: https://eur-lex.europa. eu/legal-content/EN/TXT/?uri=CELEX\%3A61964CJ0006

ECJ (1978) Judgment of the Court of 9 March 1978. 106/77 Amministrazione delle Finanze dello Stato $v$ Simmenthal SA. Retrieved from: https://eur-lex.europa.eu/legal-content/EN/TXT/?uri=CELEX\%3A61977CJ0106

CJEU (2018) Judgment of the Court (Grand Chamber) of 25 July 2018. C-216/18 PPU.Retrieved from: http://curia.europa. eu/juris/liste.jsf?num=C-216/18

Harbaceviča, S. (2016). Eiropas Savienības likumdošanas pārn̦emšana Latvijas likumdošanā un tiesībās. In: Atgriešanās Eiropā Latvijas prezidentu, premjerministru, ministru un diplomātu esejās. No starptautiskās atzišanas līdz pirmajai prezidentūrai Eiropas Savienībā. 1990-2015. Rīga: Zinātne, 199.-215. Ipp.

Jundzis, T. (2001). The Baltic States at Historical Crossroads. Political, economical, and legal problems and opportunities in the context of international co-operation at the beginning of $21^{\text {st }}$ century. A collection of articles. Second revisited and expanded version. Rīga: Latvian Academy of Science, pp. 114-137.

Kalniña, V. (2019). Kā Eiropas Savienības Tiesa vērtē tiesiskuma un tehnolog̣iju izaicinājumus. Intervija ar Eiropas Savienības tiesas prezidentu Kūnu Lēnartsu. Jurista Vārds, Nr. 45, 10.-16.

Kelemen, R. D., Schmidt, S. K. (2012). Introduction - the European Court of Justice and legal integration: perpetual momentum? Journal of European Public Policy, Vol. 19, No. 1, 1-7.

Krūma, K., Statkus, S. (2019). The Constitution of Latvia - A Bridge Between Traditions and Modernity. In: National Constitutions in European and Global Governance: Democracy, Rights, the Rule of Law. A. Albi and S. Bardutzky (eds.). The Hague: T. M. C. Asser Press, pp. 951-995.

Kucina, I. (2020). Vācijas konstitucionālās tiesas spriedums: ES tiesību telpas satricinājums. Jurista Vārds, Nr. 21, 6.-12.

Kühn, Z. (2004). Worlds Apart: Western and Central European Judicial Culture at the Onset of the European Enlargement. The American Journal of Comparative Law, Vol. 52, No. 3, 531-567.

Lejnieks, M., Pleps, J., Ziemele, I. (2019). Satversmes 68. pants. In: Latvijas Republikas Satversmes komentāri. V nodaļa. Likumdošana. Sagatavojis aut. kol. prof. R. Baloža zinātniskā vadībā. Rīga: Latvijas Vēstnesis, 87.-129. Ipp. 
Levits, E. (1999). Latvijas tiesiskā iekārta transformācijā. Likums un Tiesības, 1. sēj., Nr. 1, 6.-12.

Levits, E. (2000). Satversme un Eiropas Savienība. Jurista Vārds, Nr. 23, 1., 5.

Levits, E. (2007). Eiropas Savienības tiesības un Satversme. In: Eiropas tiesības. Otrais papild. izd. Rīga: Juridiskā koledža, 579.-592. Ipp.

Levits, E. (2018a). Valstsgriba. Idejas un domas Latvijai. 1985-2018. Rīga: Latvijas Vēstnesis, 392. Ipp.

Levits, E. (2018b). Latvijas tiesību attīstība kopš 1990. gada - no padomju sistēmas uz modernu Eiropas Savienības dalībvalsts tiesību sistēmu. Augstākās Tiesas Biḷetens, Nr. 17, 56.-59.

Levits, E. (2020a).Address of the President of Latvia, Egils Levits, the 2020 Opening Sitting of the Constitutional Court of Latvia. Retrieved from: https://www.president.lv/en/news/news/address-of-the-president-of-latvia-egils-levits-the2020-opening-sitting-of-the-constitutional-court-of-latvia-26093

Levits, E. (2020b). Address of the President of Latvia, Egils Levits, at the Latvian-Soviet Peace Treaty Centenary event. Retrieved from: https://www.president.lv/en/news/news/address-of-the-president-of-latvia-egils-levits-at-the-latvian-soviet-peace-treaty-centenary-event-26347

Neimanis, J. (2004). levads tiesībās. Rīga: zv. adv. J. Neimanis.

Neimanis, J. (2011). The Role of a Judge in European Integration. In: European Integration and Baltic Sea Region: Diversity and Perspectives. Muravska, T. (ed.). Rīga: University of Latvia Press, pp. 169-177.

Osipova, S. (2018). Latvijas Republikas konstitucionālā identitāte Satversmes tiesas spriedumos. Jurista Vārds, Nr. 27, 8.-13.

Pleps, J., Plepa, D. (2016). Satversmes tiesas ietekme uz Latvijas tiesiskās sistēmas attīstību. Jurista Vārds, Nr. 49, $24 .-31$.

Pleps, J. (2018) Latvijas valsts konstitucionālie pamati. In: Latvija un latvieši. Akadēmiskie raksti 2 sējumos. I sēj. Rīga: Latvijas Zinātņu akadēmija, 84.-118. Ipp.

Raihs, N., Godars, K., Vasiljjeva, K. (2004). Izprotot Eiropas Savienības tiesības. Kopienas tiesību mērksi, principi un metodes. Rīga: Tiesu Namu Aǵentūra.

Rezevska, D., Ziemele, I. (2013) 15. pants. In: Administratīvā procesa likuma komentāri. A un B daḷa. Sagatavojis aut. kol. Dr. iur. J. Briedes zinātniskajā redakcijā. Rīga: Tiesu Namu Aǵentūra, 223.-259. Ipp.

Rodina, A., Pleps, J. (2013). Constitutionalism in Latvia: Reality and Perspectives. In: New Millenium Constitutionalism: Paradigms of Reality and Challenges. Yerevan: Njhar, pp. 431-472.

Sadurski, W. (2012). Constitutionalism and the Enlargement of Europe. Oxford: Oxford University Press.

Sadurski, W. (2019). Poland's Constitutional Breakdown. Oxford: Oxford University Press.

Sajó, A. (1999). Limiting Government. An Introduction to Constitutionalism. Budapest: Central European University Press.

Constitutional Court (2002). Judgment in case No. 2001-09-01 "On the Compliance of the Cabinet of Ministers February 27, 2001 Regulations No.92 "Procedure for Stating the Amount of Sugar-Beet Supply for Sugar-Beet Growers with Article 91 of the Satversme". Retrieved from: https://www.satv.tiesa.gov.lv/web/viewer.html?file=/wp-content/ uploads/2001/08/2001-09-01_Spriedums_ENG.pdf

Constitutional Court (2003a). Judgment in case No. 2003-08-01 "On the Compliance of Article 96 (the first sentence of the second part) of the Criminal Procedure Law of Latvia with Articles 89 and 92 of the Satversme". Retrieved from: https://www.satv.tiesa.gov.lv/web/viewer.html?file=/wp-content/uploads/2003/04/2003-08-01_Spriedums_ENG.pdf

Constitutional Court (2003b). Judgment in case No. 2002-18-01 "On the Compliance of Article 2, Item 2 of the Saeima Election Law with Articles 6, 8 and 91 of the Satversme". Retrieved from: https://www.satv.tiesa.gov.lv/web/viewer. html?file=/wp-content/uploads/2002/10/2002-18-01_Spriedums_ENG.pdf

Constitutional Court (2004). Judgment in case No. 2004-01-06 "On the Compliance of Article $114^{2}$ of the Administrative Violation Code with April 9, 1965 Convention on Facilitation of International Maritime Traffic". Retrieved from: https:// www.satv.tiesa.gov.lv/web/viewer.html?file=/wp-content/uploads/2004/01/2004-01-06_Spriedums_ENG.pdf

Constitutional Court (2006). Judgment in case No. 2005-13-0106 "On the Compliance of Section 5 (Items 5 and 6) of the Saeima (Parliament) Election Lawand Section 9 (Items 5 and 6 of the first Paragraph) of the City Dome, District Council and Rural District Council Election Law with Sections 1, 9, 91 and 101 of the Satversme as well as with Sections 25 and 26 of the International Covenant on Civil and Political Rights". Retrieved from: https://www.satv.tiesa.gov.lv/ web/viewer.html?file=/wp-content/uploads/2005/06/2005-13-0106_Spriedums_ENG.pdf

Constitutional Court (2007). Judgment in case No. 2006-29-0103 "On Compliance of Para 5 of the Transitional Provisions of the State Civil Service Law and Regulation of 20 February 2001 by the Cabinet of Ministers No. 79 "Regulations 
onApplication Order and Term of the Mandatory Requirement for Civil Servants - Higher Education" with Articles1, 91, 101 and 106 of the Satversme". Retrieved from: https://www.satv.tiesa.gov.lv/web/viewer.html?file=/wp-content/ uploads/2006/11/2006-29-0103_Spriedums_ENG.pdf

Constitutional Court (2008). Judgment in case No. 2007-11-03 “On Compliance of the Part of Riga Land Use Plan 2006 -2018 Covering the Territory of the Freeport of Riga with Article 115 of the Satversme”. Retrieved from: https://www. satv.tiesa.gov.lv/web/viewer.html?file=/wp-content/uploads/2007/05/2007-11-03_Spriedums_ENG.pdf

Constitutional Court (2009a). Judgment in case No. 2008-35-01 "On Compliance of the Law "On the Treaty of Lisbon Amending the Treaty of European Union and the Treaty Establishing the European Community" with Article 101 of the Satversme". Retrieved from: https://www.satv.tiesa.gov.lv/web/viewer.html?file=/wp-content/uploads/2008/09/ 2008-35_01_ENG.pdf

Constitutional Court (2009b). Judgment in case No. 2008-47-01 "On Compliance of the Words "not Later than within 60 Days" of the Third Part of Section 32 of the Law "On Prevention of Laundering of the Proceeds from Crime and Financing of Terrorism" with Article 105 of the Satversme". Retrieved from: https://www.satv.tiesa.gov.lv/web/ viewer.html?file=/wp-content/uploads/2008/11/2008-47-01_Spriedums_ENG.pdf

Constitutional Court (2011). Judgment in case No. 2011-05-01 "On Compliance of Section 39 (1) Indent 6 of the Public Procurement Law with Article 91 and 105 of the Satversme”. Retrieved from: https://www.satv.tiesa.gov.lv/web/ viewer.html?file=/wp-content/uploads/2011/03/2011-05-01_Spriedums_ENG.pdf

Satversmes tiesa [Constitutional Court] (2017a). Par jautājumu uzdošanu Eiropas Savienības Tiesai prejudiciāla nolēmuma pieņemšanai lietā Nr. 2016-04-03: Satversmes tiesas 2017. gada 28. februāra lēmums lietā Nr. 2016-04-03. Latvijas Vēstnesis, 2. marts, Nr. 46.

Constitutional Court (2017b). Judgment in case No. 2016-07-01 "On Compliance of Section 356(2) and Section 360(1) of the Criminal Procedure Law with Article1, the first sentence of Article 91, Article 92 and Article 105 of the Satversme". Retrieved from: https://www.satv.tiesa.gov.lv/web/viewer.html?file=/wp-content/uploads/2016/05/2016-07-01_ Spriedums_ENG.pdf

Satversmes tiesa [Constitutional Court] (2018a). Par Rīgas domes 2015. gada 9. jūnija saistošo noteikumu Nr. 148 "Par nekustamā īpašuma nodokli Rīgā” 3.1. punkta atbilstību Latvijas Republikas Satversmes 91. pantam un Līguma par Eiropas Savienības darbību 18. panta pirmajai dalıa un 21. panta pirmajai daļai: 2018. gada 29. jūnija spriedums lietā Nr. 2017-28-0306. Latvijas Vēstnesis, 2. jūlijs, Nr. 130.

Satversmes tiesa [Constitutional Court] (2018b). Par Ministru kabineta 2015. gada 14. aprīla noteikumu Nr. 187 "Grozījums Ministru kabineta 2004. gada 30. novembra noteikumos Nr. 1002 "Kārtība, kādā ieviešams programmdokuments “Latvijas Lauku attīstības plāns Lauku attīstības programmas īstenošanai 2004.-2006. gadam”"” atbilstību Latvijas Republikas Satversmes 105. pantam: 2018. gada 18. decembra spriedums lietā Nr. 2016-04-03. Latvijas Vēstnesis, 19. decembris, Nr. 249.

Satversmes tiesa [Constitutional Court] (2018c). Par Sauszemes transportlīdzeklu īpašnieku civiltiesiskās atbildības obligātās apdrošināšanas likuma 41. panta pirmās dal̦as 1. punkta "d" apakšpunkta atbilstību Latvijas Republikas Satversmes 105. pantam: 2018. gada 6. jūnija spriedums lietā Nr. 2017-21-01. Latvijas Vēstnesis, 7. jūnijs, Nr. 112.

Constitutional Court (2018d). Judgment in case No. 2017-25-01 "On the compliance of Article 5(6) of the Saeima Election Law with Articles 1, 9 and 91 of the Satversme". Retrieved from: https://www.satv.tiesa.gov.lv/web/viewer.html?file=/ wp-content/uploads/2017/10/2017-25-01_Judgment_ENG.pdf

Satversmes tiesa [Constitutional Court] (2019a). Par jautājumu uzdošanu Eiropas Savienības tiesai prejudiciāla nolēmuma pieņemšanai lietā Nr. 2018-18-01: 2019. gada 4. jūnija lēmums lietā Nr. 2018-18-01. Latvijas Vēstnesis, 6. jūnijs, Nr. 113.

Satversmes tiesa [Constitutional Court] (2019b). Par Valsts un pašvaldību institūciju amatpersonu un darbinieku atlīdzības likuma 3. panta 9. ${ }^{2}$ dalas 1. un 2. punkta atbilstību Latvijas Republikas Satversmes 96. pantam: 2019. gada 6. marta spriedums lietā Nr. 2018-11-01. Latvijas Vēstnesis, 8. marts, Nr. 48.

Satversmes tiesa [Constitutional Court] (2019c). Par Augstskolu likuma 27. panta piektās daļas un 30. panta ceturtās daļas atbilstību Latvijas Republikas Satversmes 106. panta pirmajam teikumam: 2019. gada 7. jūnija spriedums lietā Nr. 2018-15-01. Latvijas Vēstnesis, 10. jūnijs, Nr. 116.

Satversmes tiesa [Constitutional Court] (2019d). Par tiesvedības izbeigšanu lietā Nr. 2018-20-01: 2019. gada 8. oktobra lēmums lietā Nr. 2018-20-01. Latvijas Vēstnesis, 9. oktobris, Nr. 205.

Satversmes tiesa [Constitutional Court] (2020a). 2020. gada 11. jūnija rīcības sēdes lēmums lietā Nr. 2019-28-0103. Latvijas Vēstnesis, 17. jūnijs, Nr. 117. 
Satversmes tiesa [Constitutional Court] (2020b). Par jautājumu uzdošanu Eiropas Savienības tiesai prejudiciāla nolēmuma pien̦emšanai lietā Nr. 2020-33-01: 2020. gada 14. jūlija lēmums lietā Nr. 2020-33-01. Latvijas Vēstnesis, 16. jūlijs, Nr. 135.

Schuman, R. (1950). Declaration of $9^{\text {th }}$ May 1950 delivered by Robert Schuman. Retrieved from: https://www.robertschuman.eu/en/doc/questions-d-europe/qe-204-en.pdf

Tamm, D. (2013). The History of the Court of Justice of the European Union Since its Origin. In: The Court of Justice and the Construction of Europe: Analyses and Perspectives on Sixty Years of Case-law. La Cour de Justice et la Construction de l'Europe: Analyses et Perspectives de Soixante Ans de Jurisprudence. The Hague: Asser Press, pp. 9-36.

Taurēns, J., Feldmanis, I. (2016). Latvijas ārpolitika un diplomātija 20. gadsimtā. 3. sēj. Rīga: Jumava.

Van Rompuy, H., Barroso, J. M. D. (2012). From War to Peace. A European tale. Acceptance speech of the Nobel Peace Prize award to the European Union. Retrieved from: https://europa.eu/european-union/sites/europaeu/files/docs/body/ npp2013_en.pdf

Ziemele, I. (2004). Atsevišḳu Latvijas Republikas Satversmes grozījumu nepieciešamības pamatojums sakarā ar Eiropas Savienības tiesību integrāciju Latvijas tiesību sistēmā. Likums un Tiesības, 6. sēj., Nr. 3, 66.-70.

Ziemele, I. (2018). Konstitucionālās tiesas kā slūžas globalizētā pasaulē. Jurista Vārds, Nr. 46, 8.-12.

Ziemele, I. (2019). Moderns tiesiskums Eiropas pilsonim. Retrieved from: https://juristavards.lv/eseja/275455-modernstiesiskums-eiropas-pilsonim/

Ziemele, I. (2020). Eiropas Savienības tiesību konstitucionalitātes kontrole Latvijā. Jurista Vārds, 7. jūlijs, Nr. 27, 12.-19.

\section{References for Part 2}

\subsection{Poverty and inequality in Latvia. In line with European values? Baiba Bela}

Bela, B. (red.) (2018). Ilgtspējīga attīstība un sociālās inovācijas. Rīga: LU Akadēmiskais apgāds.

Bela, B. (red.) (2013). Latvija. Pārskats par tautas attīstību. Ilgtspējīga nācija. Rīga: LU SPPI.

Centrālā statistikas pārvalde [Central Statistical Bureau of Latvia] (2020). Bērni Latvijā. Retrieved from: https://www.csb. gov.lv/lv/statistika/statistikas-temas/iedzivotaji/iedzivotaju-raditaji/meklet-tema/418-berni-latvija-2020

Corak, M. (2013). Income Inequality, Equality of Opportunity, and Intergenerational Mobility. Journal of Economic Perspectives, 27(3), 79-102.

Cunska, Z. \& Muravska, T. (2009). Sociālās politikas īstenošana Latvijā pēc pievienošanās ES. Rīga: Eiropas Komisijas pārstāvniecība Latvijā. Retrieved from: http://providus.lv/article/socialas-politikas-istenosana-latvija-pecpievienosanas-es

Dārziņa, L. (2019). Nodokḷa atvieglojumiem algas par mazu. 2019. gada 18. martā. Retrieved from: https://lvportals.lv/ skaidrojumi/302735-nodokla-atvieglojumiem-algas-par-mazu-2019

European Commission (n. d.). Eiropas sociālo tiesību pīlārs. Retrieved from: https://ec.europa.eu/commission/priorities/ deeper-and-fairer-economic-and-monetary-union/european-pillar-social-rights_lv

Eppard, M.L., Chomsky, N., Rank, M. \& Brady, D. (2017). On culture, politics, and poverty. Contexts. 16 (4): 8-11. DOI $10.1177 / 1536504217742382$

ESPN (European Social Policy Network). (2015). Social Investment in Europe - A study of national policies. Retrieved from: https://ec.europa.eu/social/main.jsp?catld=738\&langld=en\&publd=7881\&furtherPu

European Union. doi:10.2806/670582 Retrievied: https://www.eurofound.europa.eu/ sites/default/ files/ef_publication/ field_ef_document/ ef19028en.pdf

European Union (2019). Review of the social situation and the development in the social protection policies in the Member States and the Union. 2019 Annual Report from the Social Protection Committee. Brussels: European Commission. Directorate-General for Employement, Social Affairs and Inclusion. doi:10.2767/963589

Eurostat (2019). Newsrelease. Downward trend in the share of persons at risk of poverty or social exclusion in the EU. 158/2019 - 16 October 2019. Retrieved from: https://ec.europa.eu/eurostat/documents/2995521/10163468/316102019-CP-EN.pdf/edc3178f-ae3e-9973-f147-b839ee522578

Īsi par ES, b.g. [Shortly about EU, n.d.]. Retrieved from: https://europa.eu/european-union/about-eu/eu-in-brief_lv 
Koval̦evska, A. (2018). Sociāli atbildīgas valsts princips kā Latvijas Republikas valsts iekārtu raksturojošs princips. In: Bela, B. (red.). Ilgtspējīga attīstība un sociālās inovācijas. Rīga: LU Akadēmiskais apgāds, 32.-67. Ipp.

Labklājības ministrija [Welfare Ministry] (2014). Koncepcija par minimālā ienākuma līmeņa noteikšanu. Ministru kabineta 2014. gada 30. oktobra rīkojums Nr. 619. Retrieved from: http://www.Im.gov.lv/upload/sociala_ieklausana/koncepcija_fin.pdf

Lāce, T. (2012). Sociālā atstumtība Latvijā. Rīga: Zinātne.

Lāce, T. (2018). Valdības politika bērnu nabadzības un sociālās atstumtības mazināšanā Latvijā. In: Rajevska, F. (red.). Sociālās politikas transformācijas līkloči). Valmiera: Vidzemes Augstskola, 24.-49. Ipp.

Latvijas Republikas Saeima (2010). Latvijas ilgtspējīgas attīstības stratēǵija līdz 2030. gadam. Apstiprināts ar 2010. gada 10. jūnija Latvijas Republikas Saeimas lēmumu. Retrieved from: http://www.latvija2030.lv/upload/latvija2030_ saeima.pdf

Latvija. Valsts veselības pārskats 2017. OECD, World Health Organization and the European Observatory on Health Systems and Policies. Retrieved from: https://www.oecd.org/publications/latvija-valsts-veselibas-parskats-20179789264285262-Iv.htm

Pārresoru koordinācijas centrs [Cross-Sectoral Coordination Centre] (2012). Latvijas Nacionālais attīstības plāns 2014.2020. gadam. Apstiprināts ar 2012. gada 20. decembra Latvijas Republikas Saeimas lēmumu. Retrieved from: https:// www.pkc.gov.lv/sites/default/files/inline-files/20121220_NAP2020\% 20apstiprinats\%20Saeima_4.pdf

Pārresoru koordinācijas centrs [Cross-Sectoral Coordination Centre] (2020). Latvijas Nacionālais attīstības plāns 2021.2027. gadam. Apstiprināts ar 2020. gada 2. jūlija Latvijas Republikas Saeimas lēmumu. Retrieved from: https://www. pkc.gov.lv/sites/default/files/inline-files/NAP2027_apstiprin\%C4\%81ts\% 20Saeim\%C4\%81_1.pdf

Plāns minimālo ienākumu atbalsta sistēmas pilnveidošanai 2020.-2021. gadam (2019). Ministru kabineta 2019. gada 22. augusta rīkojums Nr. 408. Retrieved from: https://www.vestnesis.lv/op/2019/173.4

Rajevska, F. (2018). Sociālās politikas transformācijas līkloči Latvijā pēckrīzes posmā. Valmiera: Vidzemes Augstskola.

Rajevska, F. \& Rajevska, O. (2019). Social policy reforms in Latvia. Shift towards individual responsibility of welfare. In: Blum, S. et al. (eds.). Routledge Handbook of European Welfare Systems. Taylor \& Francis Group, pp. 348-366. Retrieved from: http://ebookcentral.proquest.com/lib/lulv/detail.action?docID=5982844

Satversmes Tiesa [Constitutional Court] (2020). Norma, kas nosaka garantēto minimālo ienākumu līmeni, neatbilst Satversmes 1. un 109. pantam. Retrieved from: https://www.satv.tiesa.gov.lv/press-release/norma-kas-nosakagaranteto-minimalo-ienakumu-limeni-neatbilst-satversmes-1-un-109-pantam/

Stiglitz, J. E. (2012). The Price of Inequality. New York, London: W. W. Norton \& Company.

Stiglitz, E. J. (2015). The Origins of Inequality, and Policies to Contain It. National Tax Journal. 68(2), 425-448. Doi: dx.doi. org/10.17310/ntj.2015.2.09

The Council of the European Union (2015). Council Recommendation of 14 July 2015 on the 2015 National Reform Programme of Latvia and delivering a Council opinion on the 2015 Stability Programme of Latvia (2015/C 272/17). Retrieved from: http://ec.europa.eu/europe2020/pdf/csr2015/csr2015_council_latvia_en.pdf

The Council of the European Union (2016). Council Recommendation of 12 July 2016 on the 2016 National Reform Programme of Latvia and delivering a Council opinion on the 2016 Stability Programme of Latvia (2016/C 299/20). Retrieved from: http://eur-lex.europa.eu/legal-content/EN/TXT/PDF/?uri= CELEX:32016H0818(20)\&from=EN

The Council of the European Union (2017). Council Recommendation of 11 July 2017 on the 2017 National Reform Programme of Latvia and delivering a Council opinion on the 2017 Stability Programme of Latvia (2017/C 261/13). Retrieved from: https://eur-lex.europa.eu/legal-content/EN/TXT/PDF/?uri=CELEX:32017H0809(13)\&from=EN

The Council of the European Union (2018). Council Recommendation of 13 July 2018 on the 2018 National Reform Programme of Latvia and delivering a Council opinion on the 2017 Stability Programme of Latvia (2017/C 320/13). Retrieved from: https://eur-lex.europa.eu/legal-content/EN/TXT/PDF/?uri=CELEX:32018H0910(13)\&rid=9

The World Bank (2013). Latvia: Who is Unemployed, Inactive or Needy? An Assessment of Post-Crisis Policy Options. Retrieved from: http://www.lm.gov.lv/text/2562

United Nations Development Programme (2019). Beyond income, beyond averages, beyond today: Inequalities in human development in the 21st century. Human Development Report. New York: United Nations Development Programme. Retrieved from: http://hdr.undp.org/en/content/human-development-report-2019

Wilkinson, R., \& Pickett, K. (2010). The Spirit Level: Why Greater Equality Makes Societies Stronger. New York: Bloomsbury Publishing. 


\section{Secondary data and databases}

Centrālās statistikas pārvalde [Central Statistical Bureau] (2019). Sociālās aizsardzības izdevumi pēc ESSPROS klasifikācijas Latvijā (milj. euro). Tabulas kods datubāzē SDG150. Rīga. Retrieved from: https://www.csb.gov.lv/lv/statistika/statistikas-temas/socialie-procesi/sociala-drosiba/tabulas/sdg150/socialas-aizsardzibas-izdevumi-pec-esspros

Eurostat (2020a). Gini coefficient of equivalised disposable income - EU-SILC survey. Retrieved from: http://appsso. eurostat.ec.europa.eu/nui/show.do?lang=en\&dataset=ilc_di12

Eurostat (2020b). Government expenditure on social protection. Retrieved from: https://ec.europa.eu/eurostat/statisticsexplained/index.php/Government_expenditure_on_social_protection\#Expenditure_on_.27social_protection.27

Eurostat (2020c). At-risk-of-poverty rate before social transfers (pensions included in social transfers) by poverty threshold, age and sex - EU-SILC and ECHP surveys. Code ilc_li09. Retrieved from: https://ec.europa.eu/eurostat/web/productsdatasets/product?code=ilc_li09

Eurostat (2020d). People at risk of poverty after social transfers. Code: t2020_52. Retrieved from: https://ec.europa.eu/ eurostat/en/web/products-datasets/-/T2020_52

OECD (2020). Income inequality (indicator). Doi: 10.1787/459aa7f1-en

\subsection{Opportunities and challenges of the Common Agricultural Policy for Latvia's rural areas. Aija Zobena}

AREI [IARE] (2018). Atskaite. Lauku attīstības programma 2014-2020. LEADER/SVVA analīze. Retrieved from: https://www. arei.lv/sites/arei/files/files/lapas/LAP_SVVA_\%20analize_21.12.2018.LAND_.pdf

AREI [IARE] (2019). Atskaite. LAP 2014-2020 novērtēšana paplašinātajam Ikgadējam īstenošanas ziṇojumam 2019. Retrieved from: https://www.arei.lv/sites/arei/files/files/lapas/AIR2019_LAPnovert\%20_zinojums_2019_gala.pdf

Bela, B., Koval̦evska, A., Niklass, M., N̦ikišins, J., Rasnača, L., Reinholde, I., Spurava, G. (2018). Ilgtspējīgas attīstības sociālā dimensija - kā virzāmies uz priekšu ciennpilnai dzīvei sociāli atbildīgā valstī. In: Zobena, A. (zin. red.). Inovatīvi risinājumi ceḷā uz ilgtspēju: sabiedrība, ekonomika, vide. Rīga: LU Akadēmiskais apgāds, 110.-143. Ipp.

Busch, L. (2016). Individual choice and social values: Choice in the agrifood sector. Journal of Consumer Culture, Vol. 16(1), 124-143. DOI: 10.1177/1469540514536193 (skatīts 09.08.2020.).

CSP [CSB - Central Statistical Bureau of Latvia] (2020). Latvija. Galvenie statistikas rādītāji 2020. Rīga: CSP.

Dessein, J., Bock, B. B., de Krom, M. P. (2013). Investigating the limits of multifunctional agriculture as the dominant frame for green care in agriculture in Flanders and the Netherlands. Journal of Rural Studies, 32, 50-59.

European Commission (2020). EU funding programmes 2014-2020. Retrieved from: https://ec.europa.eu/info/strategy/ eu-budget/spending/topic/eu-funding-programmes-2014-2020_en

Gorton, M., and White, J. (2007). The restructuring of agrifood supply chains in CEE and the CIS Overview and policy implications. In: Outlook on AGRICULTURE, Vol 36, No. 4, 237-246.

Melece, L. (2018). Inovatīvi risinājumi ilgtspējīgai lauku attīstībai. In: Zobena, A. (zin. red.). Inovatīvi risinājumi ceḷā uz ilgtspēju: sabiedrība, ekonomika, vide. Rīga: LU Akadēmiskais apgāds, 184.-209. Ipp.

Ministry of Agriculture (2020). Rural development. Retrieved: https://www.zm.gov.lv/en/lauku-attistiba/statiskas-lapas/ support?nid=1154\#jump

OECD (2019). Inovācijas, lauksaimniecības produktivitāte un ilgtspējība Latvijā. Retrieved from: https://www.zm.gov.lv/ public/ck/files/OECD_petijums_LAT.pdf

United Nations (2019). World Urbanization Prospects: The 2018 Revision. New York: United Nations. Retrieved from: https:// population.un.org/wup/Publications/Files/WUP2018-Report.pdf

van Huyienbroek, G., Durand, G., (eds.) (2003). Multifunctional agriculture: a new paradigm for European agriculture and rural development. Aldershot: Ashgate.

\subsection{Not every tree in the forest stands tall. Europeanization of the media environment. Klinta Ločmele}

Akule, D. (2017). The Europeanization of Latvia: Becoming good Europeans? Providus. Retrieved from: http://providus.lv/ article_files/1286/original/Akule_v1.pdf?1328603457

Ārlietu ministrija [Ministry of Foreign Affairs] (2004a). Kultūra un audiovizuālā politika (20. sadaḷa). Retrieved from: https:// web.archive.org/web/20041108024730/http://www.mfa.gov.lv/lv/eu/3749/3826/3847/ 
Ārlietu ministrija [Ministry of Foreign Affairs] (2004b). Latvijas Republikas sarunu pozīija. 20. sadaḷa "Kultūra un audiovizuālā politika". Retrieved from: https://web.archive.org/web/20041107213319/http://www.mfa.gov.lv/lv/ eu/3749/3752/3776/

Augstākā Padome [Supreme Council] (1990). Likums "Par presi un citiem masu informācijas līdzekliem”. Retrieved from: https://likumi.lv/ta/id/64879-par-presi-un-citiem-masu-informacijas-lidzekliem

[s. n.] (2014). Darbu uzsāk LTV speciālkorespondente Eiropā - žurnāliste Ilze Nagla. Retrieved from: https://ltv.lsm.lv/lv/ aktualitates/darbu-uzsak-Itv-specialkorespondente-eiropa--zhurnalist?id=750

Brikše, I. (2010). Public service broadcasting: Old images, new user needs and market pressure. Central European Journal of Communication, 1, 76-79.

Brikše, I. (2016). Komunikācija. Mediji. Universitāte. Rīga: Mansards.

Dieziņa, S. (2019). Kaņepju produktu apritē gaidāmas izmaiņas. Latvijas Avīze, 27. aug., 5.

DIVA [w.y.]. Eirobusinšs. Retrieved from: http://www.diva.lv/video/eirobusins

Dunham, J. (2014). The EU should set explicit press freedom requirements for candidate countries. Retrieved from: https:// blogs.Ise.ac.uk/Isee/2014/09/02/the-eu-should-set-explicit-press-freedom-requirements-for-candidate-countries/

Eiropas Parlaments Latvijā [European Parliamentary Bureau in Latvia] (2020). Latvijas mediji no Aizkraukles, Daugavpils, Kuldïgas, Rìgas, Talsiem un Valkas Briselè tikās ar visiem no Latvijas ievēlētajiem deputātiem. Retrieved from: https:// www.facebook.com/Eiroparlaments/posts/10157610815077594

European Commission (2014). DG Enlargement Guidelines for EU support to media freedom and media integrity in enlargement countries, 2014-2020. Retrieved from: https:/ec.europa.eu/neighbourhood-enlargement/sites/near/ files/pdf/press_corner/elarg-guidelines-for-media-freedom-and-integrity_210214.pdf

European Commission (2019a). European Neighbourhood Policy And Enlargement Negotiations: Chapters of acquis. Retrieved from: https://ec.europa.eu/neighbourhood-enlargement/policy/conditions-membership/chapters-of-the-acquis_en

European Commission (2019b). European Neighbourhood Policy And Enlargement Negotiations: Freedom of expression and media. Retrieved from: https://ec.europa.eu/neighbourhood-enlargement/policy/policy-highlights/freedom-ofexpression-and-media_en

European Commission (2019c). Media freedom and investigative journalism - Call for Proposals. Retrieved from: https:// ec.europa.eu/digital-single-market/en/news/media-freedom-and-investigative-journalism-call-proposals

European Union (2018). Eurobarometer: Media use in the European Union. Retrieved from: https://op.europa.eu/en/ publication-detail/-/publication/a575c1c9-58b6-11e8-ab41-01aa75ed71a1 P. 22

Falkheimer, J., Blach-Ørsten, M., Kæmsgaard Eberholst, M., Möllerström, V. (2017). News Media and the Öresund Region: A Case of Horizontal Europeanisation? Nordicom Review, 38(1). Retrieved from: https://content.sciendo.com/view/ journals/nor/38/1/article-p1.xml

Ģiga, A. (2020a). LŽA atklātā vēstule par COVID-19 ietekmi uz nozari. Retrieved from: http://www.latvijaszurnalisti.lv/ raksti/2020/03/27/lza-atklata-vestule-par-covid-19-ietekmi-uz-nozari/

Ģiga, A. (2020b). LŽA un VP parakstītais sadarbības memorands palīdzēs novērst žurnālistu apdraudējumu. Retrieved from: http://www.latvijaszurnalisti.lv/valdes-lemumi/2020/04/21/lza-un-vp-parakstitais-sadarbibas-memorands-palidzesnoverst-zurnalistu-apdraudejumu/

Johnson, J. (2020.). Press freedom index in Latvia from 2013 to 2020. Retrieved from: https://www.statista.com/ statistics/1026395/latvia-press-freedom-index/

Kaukule, A. (2019). Latvijas Radio korespondente Briselē Ina Strazdiṇa pievienojusies Latvijas Televīzijas Ziṇu dienestam. Retrieved from: https://kokteilis.la.Iv/zurnaliste-ina-strazdina-latvija-nav-nomala-sala-pasaules-karte

Kultūras ministrija [Ministry of Culture] (2020). Saeima lemj atbalstït sabiedrisko mediju iziešanu no reklāmas tirgus. Retrieved from: https://www.km.gov.lv/lv/ministrija/jaunumi/saeima-lemj-atbalstit-sabiedrisko-mediju-iziesanu-noreklamas-tirgus-2378\#gsc.tab=0

Kupčs, E. (2020). Sabiedrisko mediju iziešanai no reklāmas tirgus vajag 8,3 miljonus eiro, bet tie politiski nav apsolīti (precizēts). Retrieved from: https://www.lsm.lv/raksts/zinas/latvija/sabiedrisko-mediju-iziesanai-no-reklamas-tirgusvajag-83-miljonus-eiro-bet-tie-politiski-nav-apsoliti-precizets.a363861/

Latvijas Satversmes Sapulce [Constitutional Assembly] (1922). Latvijas Republikas Satversme. Retrieved from: https:// likumi.lv/ta/id/57980-latvijas-republikas-satversme

LETA (2016). Budžetā prasa naudu Latvijas Radio korespondentam Briselē. Retrieved from: https://www.la.lv/ budzeta-prasa-naudu-latvijas-radio-korespondentam-brisele 
Līcīte, M., Dēvica, P. (2020). Levits sola atbalstu sabiedrisko mediju iziešanai no reklāmas tirgus. Retrieved from: https:// www.Ism.lv/raksts/zinas/latvija/levits-sola-atbalstu-sabiedrisko-mediju-iziesanai-no-reklamas-tirgus.a368873/

McCombs, M., Shaw, L. D., Weaver, H. D. (2014). New Directions in Agenda-Setting Theory and Research. Mass Communication and Society, 17(6), 781-802.

Mel̦niks, R. (2019). Čakša: nevar visu gribēt uzreiz, ir jāvienojas par prioritātēm. Diena, 26. aug., 4.-5.

Ministru kabinets [Cabinet of Ministers] (2016). 2016. gada 8. novembra rīkojums Nr. 667 "Par Latvijas mediju politikas pamatnostādnēm 2016.-2020. gadam”. Retrieved from: https://likumi.lv/ta/id/286455

Ministry of Foreign Affairs of the Republic of Latvia (2020). European Union issues of priority for Latvia in 2020. Retrieved from: https://www.mfa.gov.Iv/en/policy/european-union/latvia-and-the-eu/latvia-in-the-european-union

NEPLP, Latvijas Fakti (2018). Pētījums par Latvijas iedzīvotāju interesēm, dienaskārtību un uzticēšanos medijiem. Retrieved from: https://www.neplpadome.lv/lv/assets/documents/Petijumi/Mediju_lieto\%C5\%A1ana_atskaite_08.2018_\%20 (002).pdf

Petrova, A. (2020). Mediju uzraugs: no nākamā gada LTV7 vairs nerādīs mazākumtautību saturu. Retrieved from: ttps:// www.lsm.lv/raksts/zinas/latvija/mediju-uzraugs-no-nakama-gada-Itv7-vairs-neraidis-mazakumtautibu-saturu. a361782/

Plauka, J. (2019). lezīmē problēmjautājumus. Diena, 30. okt., 3.

Prytula, O. (2007). Investigative journalism and impunity in Ukraine. In: UNESCO. Press Freedom: Safety of Journalists and Impunity. Retrieved from: https://unesdoc.unesco.org/ark:/48223/pf0000156773

Reporters without borders (2020). Retrieved from: https://rsf.org/en/ranking

Rozenberga, M. (2015). Ziņojums: ES nespēj efektīvi aizstāvēt preses brīiību bloka iekšienē. Retrieved from: https://www. Ism.lv/raksts/zinas/arzemes/zinojums-es-nespej-efektivi-aizstavet-preses-brivibu-bloka-ieksiene.a148631/

Sabiedrības integrācijas fonds [Social Integration Foundation] (2019). Mediju atbalsta fonda konkursā tiks istenoti 29 projekti. Retrieved from: https://www.sif.gov.lv/index.php?option=com_content\&view=article\&id=10625\%3A Mediju-atbalsta-fonda-konkursa-tiks-istenoti-29-projekti\&catid=14\%3AJaunumi\&ltemid=186\&lang=lv

Saeima [Latvian Parliament] (1995). Radio un televīzijas likums [zaudējis spēku]. Retrieved from: http://m.likumi.lv/doc. php?id=36673

Saeimas Preses dienests [Saeima Press Service] (2020). Cilvēktiesību komisija otrajā lasījumā atbalsta Sabiedrisko elektronisko plašsazinas lïdzeklu un to pārvaldības likuma projektu. Retrieved from: https://www.saeima.lv/lv/ aktualitates/saeimas-zinas/28750-cilvektiesibu-komisija-otraja-lasijuma-atbalsta-sabiedrisko-elektroniskoplassazinas-lidzeklu-un-to-parvaldibas-likuma-projektu

Saurwein, F., Eberwein, T., Karmasin, M. (2019). Public Service Media in Europe: Exploring the Relationship between Funding and Audience Performance. Javnost: The Public: Journal of the European Institute for Communication and Culture, 26(3), 291-308.

Schimmelfennig, F. (2010). Europeanisation Beyond the Member States. Zeitschrift für Staats- und Europawissenschaften (ZSE) / Journal for Comparative Government and European Policy, 8(3), 319-339.

Skrebele, G. (2005). Televizijai nepietiek miljonu. Retrieved from: https://www.tvnet.lv/6170970/televizijai-nepietiekmiljonu

Tihonovs, J. (2019). Soda par sejas atpazī̌̌anas datu izmantošanu. Diena, 29. aug., 7.

Vanaga, E. L. (2015). Latvijas Radio paplašina korespondentu spēkus Briselē. Retrieved from: https://latvijasradio.Ism.Iv/lv/ par-mums/informacija-presei/?id=150

Yılmaz, G. (2016). Europeanisation or De-Europeanisation? Media Freedom in Turkey (1999-2015). South European Society and Politics, 21(1), 147-161.

Young, S. (2010). Who controls the news agenda? In: How Australia Decides: Election Reporting and the Media. Cambridge: Cambridge University Press, pp. 145-172.

Zelče, V. (2018). Mediju daudzveidības strukturālais konteksts. In: Zelče, V. (red.). Latvijas mediju vides daudzveidība. Rīga: LU Akadēmiskais apgāds, 33.-59. Ipp. 


\subsection{European values and Europeanization of Latvian society. Vita Zelče}

ADL [Anti-Defamation League] (2015). ADL/Global 100. Retrieved from: https://global100.adl.org

Asmane, A. (2018). Jaunais ìgnums par memoriālo kultūru. lejaukšanās. Rīga: Zinātne.

Bela, B., Ņikišins, J. (2018). Ilgtspējas sociālā dimensija: vai virzāmies pretī labklājībai un cieņpilnai dzīvei. In: Bela, B. (ed.). Ilgspējīga attīstība un sociālās inovācijas. Rīga: LU Akadēmiskais apgāds, 108.-139. Ipp.

Bleiere, D. (1996). Latvija 1985.-1996. gadā. Notikumu hronika. Rīga: Demokrātijas attīstības centrs; N.I.M.S.

Briedis, L. (1989). Tumsa un Vārds. Runa Dzejas dienu sarīkojumā 11. septembrī pie Raiņa pieminekḷa Komunāru laukumā. Literatūra un Māksla, Sept. 16, 2.

Council of the EU (2008). Council Framework Decision 2008/913/JHA of 28 November 2008 on Combating Certain Forms and Expressions of Racism and Xenophobia by Means of Criminal Law. Retrieved from: https://eur-lex.europa.eu/eli/ dec_framw/2008/913/oj

Dalton, R. J. (2020). Citizen Politics: Public Opinion and Political Parties in Advanced Industrial Democracies. $7^{\text {th }}$ ed. Los Angeles; etc.: Sage.

Delanty, G. (2019). Formations of European Modernity. A Historical and Political Sociology of Europe. 2nd ed. Cham: Palgrave Macmillan.

EC [European Commision] (2007). Eurobarometer 66. Public Opinion in the European Union. Fieldwork: SeptemberOctober 2006. Publication: September 2007. Brussels: European Commision. Retrieved from: https://ec.europa.eu/ commfrontoffice/publicopinion/archives/eb/eb66/eb66_en.pdf

EC [European Commision] (2013). Standard Eurobarometer 79. Spring 2013. European Citizenship. Report. Fieldwork: May 2013. Brussels: European Commision. Retrieved from: https://ec.europa.eu/commfrontoffice/publicopinion/archives/ eb/eb79/eb79_first_en.pdf

EC [European Commision] (2015). Standard Eurobarometer 84. Autumn 2015. European Citizenship. Report. Fieldwork: November 2015. Brussels: European Commision.

EC [European Commision] (2017). Standard Eurobarometer 88. Autumn 2017. European Citizenship. Report. Fieldwork: November 2017. Brussels: European Commision.

EC [European Commision] (2019a). Standard Eurobarometer 91. European Citizenship. Report. Fieldwork: June 2019. Brussels: European Commision.

EC [European Commision] (2019b). Special Eurobarometer 484. Perceptions of Antisemitism. Report. Fieldwork: December 2018. Publication: January 2019. Brussels: European Commision.

The Economist Intelligence Unit (2019). Democracy Index 2019. A Year of Democratic Setbacks and Popular Protest. [S. I.]: The Economist; Intelligence Unit.

European Parliament (2005a). European Parliament Resolution on Remembrance of the Holocaust, Anti-Semitism and Racism. Retrieved from: https://www.europarl.europa.eu/sides/getDoc.do?pubRef=-//EP//TEXT+TA+P6-TA-2005-0018+ $0+D O C+X M L+V 0 / / E N$

European Parliament (2005b). European Parliament Resolution on the Sixtieth Anniversary of the End of the Second World War in Europe on 8 May 1945. Retrieved from: https://www.europarl.europa.eu/sides/getDoc.do?pubRef=-//EP// TEXT+TA+P6-TA-2005-0180+0+DOC+XML+V0//LV

European Parliament (2008). Declaration of the European Parliament on the Proclamation of 23 August as European Day of Remembrance for Victims of Stalinism and Nazism. Retrieved from: https://www.europarl.europa.eu/sides/getDoc. do?pubRef=-//EP//TEXT+TA+P6-TA-2008-0439+0+DOC+XML+V0//EN

European Parliament (2009). European Parliament Resolution of 2 April 2009 on European Conscience and Totalitarianism. Retrieved from: https://www.europarl.europa.eu/sides/getDoc.do?pubRef=-//EP//TEXT+TA+P6-TA-2009-0213+ $0+\mathrm{DOC}+\mathrm{XML}+\mathrm{V} 0 / / \mathrm{EN}$

EU (1995). Resolution on a Day to Commemorate the Holocaust. Retrieved from: https://op.europa.eu/en/publication-detail/-/publication/7622aa58-21bc-445c-b820-760d6303555a/language-en

ljabs, I. (2018). Demokrātija Latvijā. In: Stradiņš, J. (ed.). Latvija un latvieši: akadēmiskie raksti. 1. sēj. Rīga: Latvijas Zinātñu akadēmija, 119.-143. Ipp.

Inglehart, R. (2009). Postmaterialist Values and the Shift from Survival to Self-Expression Values. In: Dalton, R. J., Klingemann, H.-D. (eds). The Oxford Handbook of Political Behavior. Oxford: Oxford University Press, pp. 223-239. 
Judt, T. (2002). The Past is Another Country: Myth and Memory in Post-War Europe. In: Müller, J.-W. (ed.). Memory and Power in Post-War Europe. Cambridge: Cambridge University Press, pp. 157-183.

Judt, T. (2005). Postwar. A History of Europe Since 1945. London: Penguin Books.

Kalniete, S. (2017). Cinītis. Rīga: Jāṇa Rozes apgāds.

Kūle, M. (2016). Jābūtības vārdi. Esejas par zināšanām un vērtībām mūsdienu Latvijā. Rīga: Zinātne.

Kūle, M. (2018). Vērtības Latvijā (eiropeisko un vispārcilvēcisko vērtību horizontā). In: Stradinš̌, J. (red.). Latvija un latvieši: akadēmiskie raksti. 1. sēj. Rīga: Latvijas Zinātņu akadēmija, 393.-433. Ipp.

LSM.Iv News editorial board (2020). Izveido brīvprātīgo palīdzības tīklu pārtikas piegādēm risku grupām, cilvēkiem pašizolācijā vai karantīnā. Retrieved from: https://www.lsm.lv/raksts/zinas/latvija/izveido-brivpratigo-palidzibastiklu-partikas-piegadem-risku-grupam-cilvekiem-pasizolacija-vai-karantina.a352910/

Melers, M. (2013). Latvijas ebreju kopienas vēsture un holokausta piemingas vietas. Rīga: Rīgas Ebreju kopienas muzejs "Ebreji Latvijā"; LU FSI.

Mieriņa, I. (2018). Politiskā atsvešinātība un anomija mūsdienu Latvijā. In: Zobena, A. (red.). Apmaldījušies brīvībāa: anomija mūsdienu Latvijā. Rīga: LU Akadēmiskais apgāds, 56.-75. Ipp.

Neumayer, L. (2019). The Criminalisation of Communism in the European Political Space after the Cold War. London; New York: Routledge.

Ozoliņa, Ž. (2013). Latvija - Eiropas Savienības dalībvalsts. In: Stradiņš, J. (galv. red.). Latvieši un Latvija. IV sēj. Latvijas kultūra, izglītība, zinātne. Rīga: Latvijas Zinātṇu akadēmija, 401.-425. Ipp.

Rozenvalds, J. (red.). (2005). Cik demokrātiska ir Latvija: demokrātijas audits. Rīga: LU Akadēmiskais apgāds.

Rozenvalds, J. (red.) (2007). Cik demokrātiska ir Latvija: demokrātijas monitorings, 2005-2007. Rīga: Zinātne.

Rozenvalds, J. (red.). (2014). Cik demokrātiska ir Latvija: demokrātijas audits, 2005-2014. Rīga: LU Sociālo un politisko pētījumu institūts.

SKDS (2019a). Latvijas iedzīvotāju apmierinātība ar to, kā darbojas demokrātija Latvijā. Retrieved from: https://www. facebook.com/photo?fbid=2823504224346555\&set=pcb.2823505091013135

SKDS (2019b). Attieksme pret apgalvojumu “Lai uzlabotu situāciju valstī, Latvijai ir nepieciešams viens stingrs līderis ar plašām pilnvarām". Retrieved from: https://www.facebook.com/photo?fbid=2539882602708720\&set=a.2193020427394941

SKDS (2019c). Kas Latvijas iedzīvotājiem darbspējas vecumā svarīgākais: darbs un karjera vai giimene? Retrieved from: https://www.facebook.com/photo?fbid=2543581419005505\&set=a.2193020427394941

Skulme, Dž. (1991). Mēs izturēsim, mēs nepadosimies. Literatūra un Māksla, Janv. 19, 1.

[S. n.] (1998). Cel̦ā uz Latvijas pilsonisku sabiedrību. Latvijas Vēstnesis, Nr. 122/123. Retrieved from: https://www. vestnesis.lv/ta/id/48017

Stranga, A. (2000). Latvijas sabiedrības attieksme pret holokaustu. Referāts starptautiskajā konferencē "Holokausta izpētes problēmas Latvijā" Rīgā 2000. gada 16. oktobrī. Latvijas Vēstnesis, Nr. 370/372. Retrieved from: https://www. vestnesis.lv/ta/id/12007

Zelče, V. (2009). History - Responsibility - Memory: Latvia's Case. In: Rozenvalds, J., Ijabs, I. (eds). Latvia. Human Develpment Report, 2008/2009: Accountability and Responsibility. Riga: Advanced Social and Political Reseach Institute. pp. 44-57.

Ziedonis, I. (1999[1988]). Raksti. 10. sēj. Rīga: Nordik. 

University of Latvia Press

Aspazijas bulvāris 5, Riga, LV-1050

E-mail: apgads@lu.lv

Printed by SIA “Drukātava” 
The Latvia Human Development Report has been published since 1995. The Advanced Social and Political Research Institute, Faculty of Social Sciences at the University of Latvia has managed and edited the Report in collaboration with partners across Latvia since 2005.

The 2019/2020 Report investigates the Europeanization of Latvia - the impact that membership of the European Union (EU) has left on Latvian politics and government, economy and society. The authors of the first part of the Report focus on changes and modernization of the state, examining, in particular, Europeanization of the political system, public administration and local governments, as well as foreign affairs and the judicial system. It also assesses the EU's impact upon the economy. The second part of the report focuses mainly on the impact of the EU on people, society and mass media. The authors reveal that the EU's impact is pronounced in the main political institutions and that the membership of the EU has fostered extensive modernization of governance. At the same time, although there has been a large-scale reorientation towards European values, Latvia's membership in the EU has not achieved substantive change in combatting poverty, inequality and depopulation of rural areas. These problems, similarly to economic development, are national-level issues, which can be resolved only through domestic government led reforms.
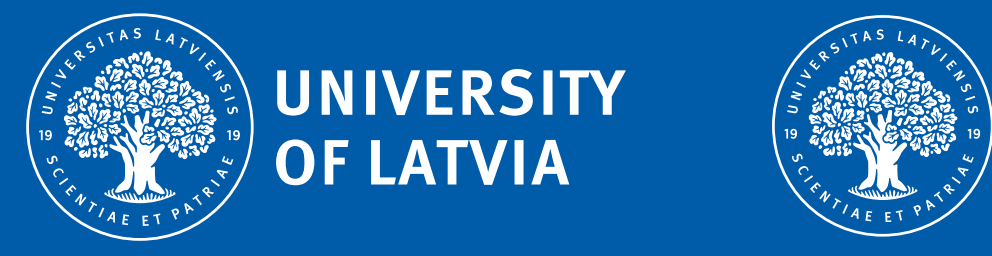

UNIVERSITY OF LATVIA

FACULTY OF SOCIAL SCIENCES

Advanced Social and Political Research Institute 